\begin{abstract}
UNIVERSIDADE DE SÃO PAULO
ESCOLA DE ENGENHARIA DE SÃO CARLOS

DEPARTAMENTO DE HIDRÁULICA E SANEAMENTO
\end{abstract}

\title{
COMPORTAMENTO DE DOIS REATORES EM BATELADA SEQÜENCIAIS AERÓBIOS COM DIFERENTES IDADES DO LODO E RETORNO TOTAL DO LODO EM EXCESSO APÓS DESINTEGRAÇÃO COM ULTRA-SOM
}

ANDRÉ LUÍS DE OLIVA CAMPOS

Tese apresentada à Escola de Engenharia de São Carlos, Universidade de São Paulo, como parte dos requisitos para obtenção do título de Doutor em Hidráulica e Saneamento

ORIENTADOR: Prof. Tit. Eduardo Cleto Pires

São Carlos

2002 
Ficha catalografica preparada pela Seçăo de Tratamento da Informaçðo do Serviço de Biblioteca - EESC/USP

Campos, André Lufs de Oliva

Comportamento de dois reatores em batelada sequenciais aerobios com diferentes idades do lodo e retorno total do lodo em excesso apos desintegraço com ultra-sca / André Luis de Oliva Campos. -. Sao Carlos, 2002.

Tese (Doutorado) -- Escola de Engenharia de são Carlos-Universidade de Săo Paulo, 2002.

Area: Hidraulica e Saneamento.

orientador: Prof. Dr. Eduardo Cleto Pires.

1. Minimização de 1odos. 2: Desintegraçăo.

3. Ultra-som. 4. Lodos ativados. 5. Batelada. I. Titulo. 


\section{FOLHA DE JULGAMENTO}

Candidato: Engenheiro ANDRÉ LUIS DE OLIVA CAMPOS

Tese defendida e julgada em $18-10-2002$ perante a Comissão Julgadora:

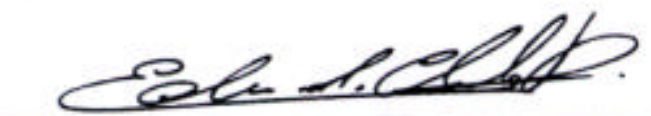

Prof. Tit. EDUARDO CLETO PIRES (Orientador)

(Escola de Engenharia de São Carlos/USP)

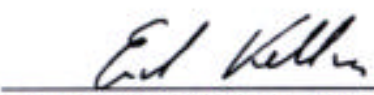

\section{Dr. ERICH KELLNER}

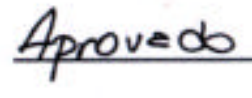

(Serviço Autônomo de Água e Esgoto - SAAE/São Carlos-SP)

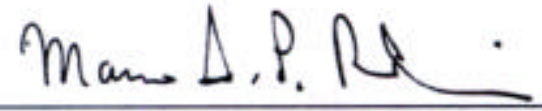

Prof. Dr. MARCO ANTONIO PENALVA REALI

(Escola de Engenharia de São Carlos/USP)

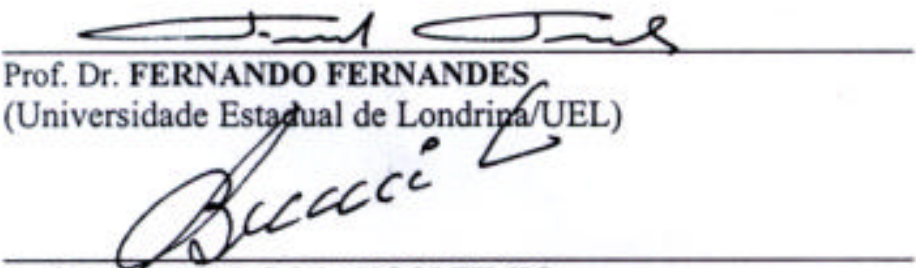

Prof. Dr. BRUNO CORAUCCI FILHO

(Universidade Estadual de Campinas/UNICAMP)
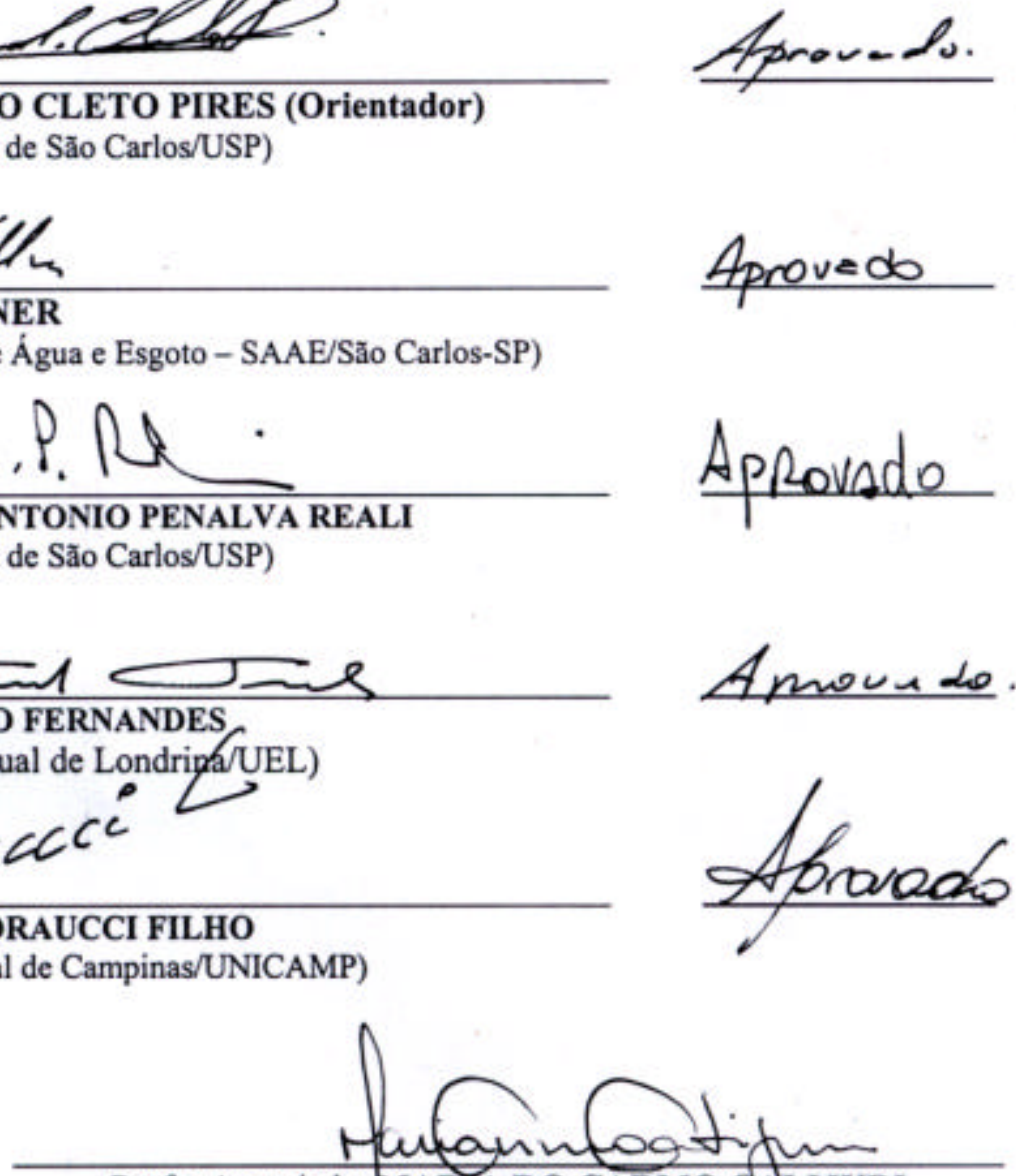

Profa. Associada MARIA DO CARMO CALIJURI

Coordenadora do Programa de Pós-Graduação em

Engenharia (Hidráulica e Saneamento) e

Presidente da Comissão de Pós-Graduação 
Ao meu pai, obrigado sempre!

À minha mãe, com saudades! 


\section{AGRADECIMENTOS}

Ao Professor Dr.Eduardo Cleto Pires, ela orientação, compreensão e paciência dispensadas;

Ao Professor Dr. Carlos Eduardo Blundi, pela ajuda no início deste Doutorado;

Aos participantes da banca de defesa: Prof. Dr. Marco Antonio Penalva Reali, Prof. Dr. Fernando Fernandes, Prof. Dr. Bruno Coraucci Filho e Dr. Erich Kellner;

Aos Professores José Roberto Campos, Rodrigo de Melo Porto, Marcelo Zaiat, Maria Bernadete Varesche e Maria do Carmo Calijuri, pela ajuda ao longo deste estudo;

A minha família que espera ansiosa o término desta jornada;

A Luciana Coêlho Mendonça, companheira de todos os momentos, beijos;

Ao grande amigo e companheiro de moradia Neyson Martins Mendonça, por sempre estar prestativo;

Aos amigos da alta cúpula: Cláudio Antônio e Cássia, Fernando Hermes Passig (Fernandão) e quem tiver na hora, Rogers e Samantha, Douglas e Karina, Romeu Gadotti e Júnior, pelas conversas técnicas e causos sempre animados, regados a cerveja, pizza e churrasco;

A Bob e Scott, os melhores labradores que uma pessoa pode ter;

Aos amigos: Marilu Parsekian, que dividiu o trabalho comigo no seu início, Marcelo Nolasco, pela troca de informações, Erich Kellner, Rogério Penetra, Dirlane 
do Carmo, Andréa Buzzini, Eraldo e Simone, Paulo Tadeu Gusmão, Nélia Callado, Márcio Barboza, Viviana Zanta, Deíza Pinto, Arnaldo Sarti, Marcelo Garcia (Bitoca), Leila Patrizzi, Luci Sartori, Cristiano Niciura, Flávia Talarico, André Oliveira (mineiro), Giovanna Tommaso, Mércia Dominguez, Gunther Brucha, José Alberto (Betão), Selma Cubas, Edson Rivelino, Ariovaldo, Valmir Moraes, Márcio Nemer, Giovani Penner, Alexandre fininho, Eduardo Cattony, Sérgio Aquino e Silvana Queiroz, Thiago Momenti, Luana Mandelli, e outros que a memória não me ajuda a lembrar...

Aos técnicos de laboratório: Paulo Fragiácomo, Maria Aparecida Viudes, Julio Trofino, Maria Ângela Talarico, Elizabeth Moraes por estarem sempre prestativos;

Ao pessoal do departamento: Sá e Pavi, Rose e Flávia. Qualquer problema conte com elas;

A Eloísa Pozzi Gianotti, pela ajuda nos exames microbiológicos e pela alegria constante;

Ao CNPq, pela bolsa concedida;

À FAPESP pela ajuda financeira no projeto. 


\section{SUMÁRIO}

Lista de Tabelas $\quad$ i

Lista de Figuras $\quad$ ii

Lista de Abreviaturas e Siglas v

Lista de Símbolos vi

Resumo ix

\begin{tabular}{ll|l} 
Abstract & $x$
\end{tabular}

1 Introdução 1

2 Objetivos 3

3 Revisão Bibliográfica $\quad 4$

3.1 Tratamento biológico de águas residuárias 4

3.2 Processo Aeróbio

$\begin{array}{ll}\text { 3.3 Lodos Ativados } & 7\end{array}$

$\begin{array}{ll}\text { 3.3.1 Microbiologia } & 7\end{array}$

$\begin{array}{ll}\text { 3.4 Fluxo intermitente (Batelada) } & 10\end{array}$

3.5 Remoção biológica de nitrogênio 13

3.6 Geração de lodo 16

3.7 Lise Celular Induzida 24

$\begin{array}{ll}\text { 3.7.1 Ultra-som } & 28\end{array}$

3.7.2 Características do lodo desintegrado 39 
4. Materiais e Métodos 42

4.1 Sistema 42

4.2 Substrato 46

$\begin{array}{ll}4.3 \text { Operação } & 47\end{array}$

$\begin{array}{ll}\text { 4.4 Ultra-som } & 50\end{array}$

4.4.1 Grau de desintegração

$\begin{array}{ll}4.5 \text { Análises } & 57\end{array}$

4.6 Monitoramento $\quad 62$

5 Resultados e Discussão 64

5.1 Testes com o ultra-som $\quad 65$

5.2 Análise microscópica do lodo submetido ao ultra-som 70

$\begin{array}{ll}\text { 5.3 Análise de DQO } & 74\end{array}$

5.3.1 Etapa controle $\quad 75$

5.4 Análise de sólidos $\quad 83$

5.4.1 etapa controle $\quad 83$

$\begin{array}{ll}\text { 5.4.2 Etapa teste } & 90\end{array}$

$\begin{array}{ll}\text { 5.5 Nutrientes } & 101\end{array}$

$\begin{array}{ll}\text { 5.5.1 Etapa controle } & 101\end{array}$

$\begin{array}{ll}\text { 5.5.2 Etapa teste } & 104\end{array}$

$\begin{array}{ll}\text { 5.6 Microbiologia } & 110\end{array}$

$\begin{array}{ll}\text { 5.6.1 Etapa controle } & 113\end{array}$

$\begin{array}{ll}\text { 5.6.2 Etapa teste } & 114\end{array}$

$\begin{array}{ll}5.7 \text { Consumo de oxigênio } & 115\end{array}$ 
6 Conclusões e Recomendações

Anexo 


\section{LISTA DE TABELAS}

Tabela 3. 1 - Doadores e receptores de elétrons em ambiente aeróbio e anaeróbio 5

Tabela 3. 2- Agrupamento de microrganismos de diversos gêneros 9

Tabela 3. 3 - Microrganismos indicadores das condições de depuração 9

Tabela 3. 4- Previsão da Produção diária de lodo em 2005

Tabela 3. 5- Tendências de gerenciamento de lodo ns Estados Unidos e Europa 22

Tabela 3. 6 - Composição química da Escherichia coli 40

Tabela 4. 1- Composição básica do esgoto sintético utilizado (Torres, 1992

$\begin{array}{ll}\text { - modificado) } & 47\end{array}$

Tabela 4. 2 - Especificações técnicas do aparelho de ultra-som 50

Tabela 4. 3 - Variáveis envolvidas nos balanços de massa 60

Tabela 4. 4 - Parâmetros analisados nas duas etapas do estudo 63

Tabela 5. 1- Tempo de exposição e eficiência do ultra-som para 200ml de amostra 67

Tabela 5. 2- Tempo de exposição e eficiência do ultra-som para 100ml de amostra $\quad 69$

Tabela 5. 3 - Freqüência dos microrganismos na amostra 110

Tabela 5. 4 - Dados de entrada para o balanço de massa do reator A - Etapa controle.

Tabela 5. 5 - Dados de entrada para o balanço de massa do reator B - Etapa controle.

Tabela 5. 6 - Dados de entrada para o balanço de massa do reator A - Etapa teste. 125

Tabela 5. 7 - Dados de entrada para o balanço de massa do reator B - Etapa teste. $\quad 127$ 


\section{LISTA DE FIGURAS}

Figura 3. 1- Etapas envolvidas na operação de um Reator Seqüencial em Batelada 11

Figura 3. 2- Transformações do nitrogênio em processos biológicos de tratamento 14

Figura 3. 3- Métodos de desintegração (Bomberg \& Kramer,1988). 25

Figura 3. 4- momento de implosão de bolha submetida ao ultra-som 29

Figura 3. 5- Esquema de implosão de uma bolha (Thorton, 2002) 30

Figura 3. 6- Processo de formação de radicais após aplicação de ultra-som (Neis, 2000) 31

Figura 4. 1- Esquema do reator seqüencial em batelada. 43

Figura 4. 2- Sistema utilizado na etapa de experimento 44

Figura 4.3 - Cones utilizados para sedimentação do lodo e análise de IVL 48

Figura 4.4 - Equipamento de ultra-som utilizado no estudo 51

Figura 4. 5 - Balanço de massa dos reatores $\quad 59$

Figura 5. 1- DQO filtrada do lodo submetido a diferentes tempos e frequiências $\begin{array}{ll}\text { de ultra-som } & 65\end{array}$

Figura 5. 2 - Variação da DQO após ultra-som para 200ml de amostra 67

Figura 5. 3- Variação da DQO após ultra-som para 100ml de amostra 68

Figura 5. 4 - Comportamento da DQO filtrada em condições de potência e tempos $\begin{array}{ll}\text { diferentes } & 69\end{array}$

Figura 5. 5- Aspecto do lodo do reator A após exposição ao ultra-som (40x) 71

Figura 5. 6- Aspecto do lodo do reator B após exposição ao ultra-som (40x) 73

Figura 5. 7- Lodo de descarte antes e depois do ultra-som.

Figura 5. 8- Eficiência de remoção em termos de DQO para o reator A - Etapa controle

Figura 5. 9 - Eficiência de remoção em termos de DQO para o reator B - Etapa controle

Figura 5. 10- Variação temporal da DQO bruta para o reator A - Etapa controle. $\quad 77$

Figura 5. 11- Variação temporal da DQO bruta para o reator B - Etapa controle. 78 
Figura 5. 12- Eficiência de remoção em termos de DQO para o reator A - Etapa teste

Figura 5. 13- Eficiência de remoção em termos de DQO para o reator B - Etapa teste

Figura 5. 14- Variação temporal da DQO bruta para o reator A - Etapa teste. 80

Figura 5. 15- Variação temporal da DQO bruta para o reator B - Etapa teste.

Figura 5. 16- Sólidos suspensos voláteis afluente para os reatores A e B - Etapa controle.

Figura 5. 17- Sólidos suspensos voláteis nos tanques dos reatores A e B - Etapa controle

Figura 5. 18- Sólidos suspensos voláteis efluente para os reatores A e B - Etapa controle.

Figura 5. 19- Relação SSF/SSV afluente para os reatores A e B - Etapa controle. 85

Figura 5. 20- Relação SSF/SSV efluente para os reatores A e B - Etapa controle.

Figura 5. 21- Relação SSF/SSV no tanque de aeração dos reatores A e B - Etapa controle.

Figura 5. 22- Índice Volumétrico do lodo para os reatores A e B - Etapa controle. $\quad 87$

Figura 5. 23- Produção de lodo (Yobs) para o reator A - Etapa controle. 89

Figura 5. 24- Produção de lodo (Yobs) para o reator B - Etapa controle. 90

Figura 5. 25- Sólidos suspensos voláteis afluente para os reatores A e B - Etapa teste.

Figura 5. 26- Sólidos suspensos voláteis no nos tanques dos reatores A e B - Etapa teste.

Figura 5. 27- Sólidos suspensos voláteis efluente para os reatores A e B - Etapa teste.

Figura 5. 28- Relação SSF/SSV afluente para os reatores A e B - Etapa teste. $\quad 94$

Figura 5. 29- Relação SSF/SSV efluente para os reatores A e B - Etapa teste. 95

Figura 5. 30- Relação SSF/SSV no tanque de aeração dos reatores A e B - Etapa teste.

Figura 5. 31- Índice Volumétrico do lodo dos reatores A e B - Etapa teste. 
Figura 5. 32- Produção de lodo (Yobs) para o reator A - Etapa teste. 97

Figura 5. 33- Produção de lodo (Yobs) para o reator B - Etapa teste. 98

Figura 5. 35- Perfil temporal de compostos nitrogenados para o reator A - Etapa

controle.

101

Figura 5. 36- Perfil temporal de compostos nitrogenados para o reator B - Etapa

controle.

103

Figura 5. 37- Teor de fósforo total afluente e efluente dos reatores A e B - Etapa controle.

103

Figura 5. 38 - Eficiência de remoção de nitrogênio total no reator A - Etapa teste.

Figura 5. 39 - Eficiência de remoção de nitrogênio total para o reator B - Etapa teste

Figura 5. 40 - Perfil de nutrientes no início da etapa teste para o reator A. 106

Figura 5. 41- Perfil de nutrientes no início da etapa teste para o reator B 107

Figura 5. 42- Perfil de nutrientes no final da etapa teste para o reator A. 108

Figura 5. 43-Perfil de nutrientes no final da etapa teste para o reator B 109

Figura 5. 44 - Microscopia dos lodos após 1 mês de aplicação do ultra-som. (40x) 111

Figura 5. 45 - Microscopia dos lodos após 2 meses de aplicação do ultra-som. (100x)

Figura 5. 46 - Microscopia dos lodos após 3 meses de aplicação do ultra-som. (100x)

Figura 5. 47 - Ensaio para verificação da TCO ao longo de um ciclo.

Figura 5. 48 - Perfil respirométrico para o reator A - Etapa controle.

Figura 5. 49 - Perfil respirométrico para o reator B - Etapa controle.

Figura 5. 50 - Perfil respirométrico para o reator A - Etapa teste.

Figura 5. 51 - Perfil respirométrico para o reator B - Etapa teste. 


\section{LISTA DE ABREVIATURAS E SIGLAS}

$\begin{array}{ll}\text { AOX } & \text { Ácidos Orgânicos Adsorvíveis } \\ \text { DQO } & \text { Demanda Química de Oxigênio } \\ \text { DQO/NTK } & \text { Razão Demanda Química de Oxigênio / Nitrogênio Total Kjeldahl } \\ \text { EPA } & \text { Environmet Proctection Agency } \\ \text { ETE } & \text { Estação de Tratamento de esgotos } \\ \text { GD } & \text { Grau de Desintegração } \\ \text { N-amoniacal } & \text { Nitrogênio amoniacal } \\ \text { NMP } & \text { Número mais Provável } \\ \text { NTK } & \text { Nitrogênio Total Kjeldahl } \\ \text { OD } & \text { Oxigênio Dissolvido } \\ \text { RMSP } & \text { Região Metropolitana de São Paulo } \\ \text { RSB } & \text { Reator Seqüencial em Batelada } \\ \text { SABESP } & \text { Companhia de Saneamento de São Paulo } \\ \text { SSF } & \text { Sólidos Suspensos Fixos } \\ \text { SST } & \text { Sólidos Suspensos Totais } \\ \text { SSV } & \text { Sólidos Suspensos Voláteis } \\ \text { TCO } & \text { Taxa de Consumo de Oxigênio } \\ \text { TDH } & \text { Tempo de Detenção Hidráulica } \\ \text { UASB } & \text { Reator Anaeróbio de Manta de lodo } \\ \text { UV } & \text { Ultravioleta } \\ \text { WEF } & \text { World Environment Federation }\end{array}$




\section{LISTA DE SÍMBOLOS}

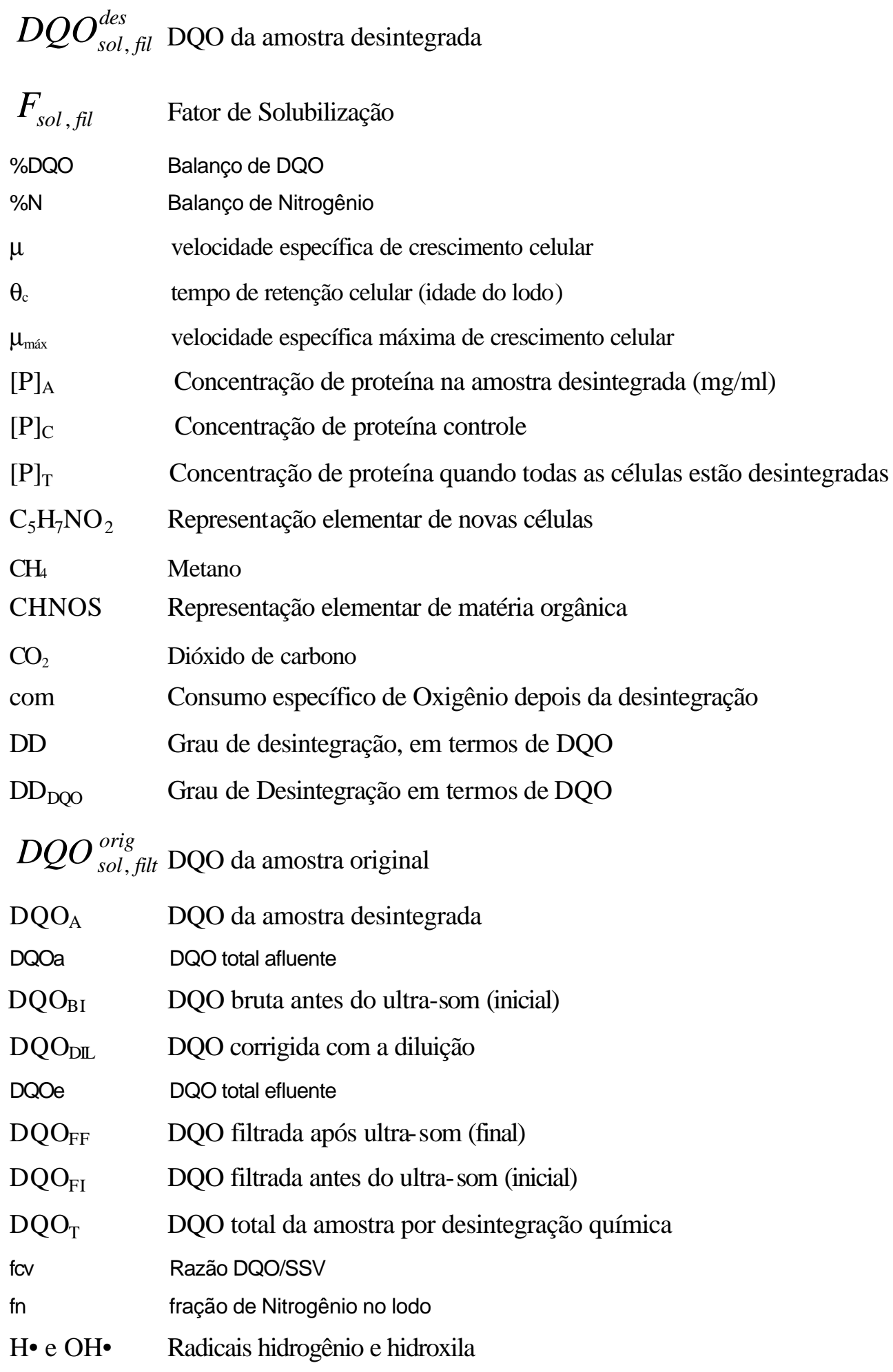




\begin{tabular}{|c|c|}
\hline $\mathrm{H}_{2}$ & molécula de hidrogênio \\
\hline $\mathrm{H}_{2} \mathrm{O}$ & Água \\
\hline $\mathrm{Hz}$ & Hertz \\
\hline IB (DD) & Inativação Biológica ou Grau de desintegração \\
\hline Khz & Kilohertz \\
\hline Mdqoe & Massa de DQO no efluente \\
\hline Mdqol & Massa de DQO no lodo \\
\hline Mdqoox & Massa de DQO oxidada \\
\hline Mhz & Megahertz \\
\hline MNI & Massa de Nitrogênio no lodo \\
\hline MNna & Massa de nitrato no afluente \\
\hline MNne & Massa de nitrato efluente \\
\hline MNs & Massa de Nitrogênio efluente \\
\hline MNtke & Massa de Nitrogênio total Kjeldahl efluente \\
\hline Mon & Massa de Oxigênio para Nitrificação \\
\hline $\mathrm{N}_{2}$ & Molécula de nitrogênio \\
\hline $\mathrm{N}_{2}$ & nitrogênio gasoso \\
\hline $\mathrm{N}_{2} \mathrm{O}$ & óxido nítrico \\
\hline $\mathrm{NH}_{3}$ & Amônia \\
\hline $\mathrm{NH}_{4}^{+}$ & Íon amônio \\
\hline Nna & Nitrato no alfuente \\
\hline Nne & Nitrato no efluente \\
\hline $\mathrm{N}-\mathrm{NH}_{4}$ & Nitrogênio como amoniacal \\
\hline $\mathrm{N}-\mathrm{NO}_{2}^{-}$ & Nitrogênio como nitrito \\
\hline $\mathrm{N}-\mathrm{NO}_{3}{ }^{-}$ & Nitrogênio como nitrato \\
\hline N-NTK & Nitrogênio como Nitrogênio total Kjeldahl \\
\hline $\mathrm{NO}_{2}^{-}$ & Nitrito \\
\hline $\mathrm{NO}_{3}^{-}$ & nitrato \\
\hline Ntka & Nitrogênio total Kjeldahl afluente \\
\hline Ntke & Nitrogênio total Kjeldahl efluente \\
\hline $\mathrm{O}_{2}$ & Molécula de oxigênio \\
\hline $\mathrm{OC}_{\mathrm{u}}$ & Consumo específico de Oxigênio antes da desintegração \\
\hline OD & oxigênio dissolvido \\
\hline Ot & Taxa de Utilização de oxigênio \\
\hline PCD & Porcentagem de desintegração \\
\hline
\end{tabular}




$\begin{array}{ll}\mathrm{pH} & \text { Potencial hidrogeniônico } \\ \mathrm{Q} & \text { vazão } \\ \mathrm{Q} & \text { Vazão afluente } \\ \mathrm{q} & \text { Vazão de lodo } \\ \mathrm{S} & \text { Enxofre } \\ \mathrm{SO}_{4}^{-} & \text {Sulfato } \\ \mathrm{Sta}^{-} & \text {DQO afluente } \\ \mathrm{Ste} & \text { DQO efluente } \\ \mathrm{Vr} & \text { Volume do reator } \\ \mathrm{X} & \text { massa celular } \\ \mathrm{Xv} & \text { SSV no tanque } \\ \mathrm{Y} & \text { coeficiente de produção celular ou de síntese celular }\end{array}$




\section{RESUMO}

Campos, A. L. O. (2002). Comportamento de dois reatores seqüenciais em batelada aeróbios com diferentes idades do lodo e retorno total do lodo em excesso após desintegração com ultra-som. São Carlos, 2002. 142pp. Tese (Doutorado) - Escola de Engenharia de São Carlos, Universidade de São Paulo.

O estudo teve por finalidade a redução do lodo gerado nos sistema aeróbios mediante recirculação do lodo em excesso, após passar por uma desintegração com ultra-som, ao tanque de aeração de cada reator. Foram utilizados dois reatores seqüenciais aeróbios (A e B) operando em sistema de batelada e com idades do lodo diferentes: 12 e 8 dias respectivamente, e com ciclos de doze horas. Os reatores foram operados em duas etapas. Na etapa inicial, chamada controle, os reatores foram operados por 130 dias sem reciclo do lodo, para se poder avaliar o comportamento e fazer futuras comparações com a etapa posterior, denominada teste. Na etapa controle foram analisados o comportamento da DQO, dos sólidos e dos nutrientes além de serem realizados testes com o ultra-som para a escolha do tempo de exposição e volume de amostra.. O reator A apresentou uma boa remoção de DQO (90,9\%), entretanto não apresentou nitrificação completa, chegando apenas na transformação de nitrogênio orgânico a amoniacal. Já a remoção de fósforo foi da ordem de 60\%. O reator B também apresentou uma boa remoção de DQO (87,7\%) e houve formação de nitrato, embora não completa, e a remoção de fósforo se situou em 57\%. Na etapa teste, que durou aproximadamente 90 dias, os reatores foram operados com retorno total do lodo após desintegração com ultra-som. Houve um aumento na DQO afluente devido ao retorno do lodo desintegrado, bem como um aumento nos teores de nitrogênio e fósforo. Houve também um aumento na concentração de sólidos dos reatores, sendo o reator A que apresentou um maior acréscimo. Ambos reatores apresentaram uma mesma eficiência na remoção de DQO (92,0\% para o reator A, e $91 \%$ para o reator B) se comparado com a etapa controle. Com relação aos nutrientes os reatores apresentaram sensível melhora na nitrificação. $\mathrm{O}$ reator $\mathrm{A}$ apresentou uma quase completa redução no nitrogênio orgânico, embora não tenha chegado a nitrificação completa. $O$ reator $B$ apresentou uma remoção completa do nitrogênio orgânico. Com relação ao fósforo, a etapa teste apresentou um decréscimo na sua remoção ( $42 \%$ para o reator A e $44 \%$ para o reator B). As análises indicaram que a desintegração do lodo e seu retorno ao tanque de aeração não causaram problemas no funcionamento dos reatores, houve uma melhora na nitrificação e não houve uma sensível redução na remoção de fósforo. Comparando com o problema de transporte, tratamento e disposição final de lodo, o estudo de redução de lodos é uma grande alternativa e que merece mais estudos.

Palavras-chave: minimização de lodos, desintegração, ultra-som, lodos ativados, batelada 


\begin{abstract}
Campos, A. L. O. (2002). Behavior of two aerobic sequential batch reactors with different sludge ages and total return of excess sludge after disintegration by ultrasound. São Carlos, 2002. 142pp. Tese (Doutorado) - Escola de Engenharia de São Carlos, Universidade de São Paulo.

The study aims to reduce the sludge generation in aerobic systems by recirculation of the excess sludge after disintegration with a ultrasound set. Two aerobic sequential batch reactors (A and $\mathrm{B}$ ) were utilized operating with two different sludge ages: 12 and 8 days respectively. The reactors were operated in two stages. In the first stage, called control, the reactors were operated for 130 days, without total sludge recirculation, to promote an assessment and compare with the next stage, called test. In the control stage the behavior of COD, solids and nutrients were analyzed, and tests with ultrasound were performed. The reactor A presented a good COD removal (90.9\%), but not a complete nitrification, and a phosphorus removal of $60 \%$. The reactor B presented a good COD removal $(87.7 \%)$ and a good organic nitrogen removal, but not complete, and a phosphorus removal of $57 \%$. In the test stage the reactors were operated for 90 days, with sludge recirculation after disintegration by ultrasound. There was an increase in influent COD, nitrogen and phosphorus because of sludge recirculation. There was an increase in MLVSS, and reactor A presented a greater increase. Both reactors presented good results in COD removal $(92.0 \%$ for reactor $\mathrm{A}$ and $91.0 \%$ for reactor $\mathrm{B})$ comparing with control stage. The reactors present a good improvement in nitrification. Reactor A presented a good organic nitrogen removal and reactor B presented a complete organic nitrogen removal. In relation to phosphorous removal, the test stage presented a decreasing in their efficiencies (42\% for reactor $\mathrm{A}$ and $44 \%$ for reactor B) regarding to control stage. The analysis showed that sludge disintegration and recirculation to aeration tank not caused any problem in the behavior of the reactors. Comparing to transport, treatment and final disposal problems, the study of sludge reduction is a great alternative that deserves attention.
\end{abstract}

Keywords: Sludge minimization, disintegration, ultrasound, activated sludge, batch. 


\section{Introdução}

Os sistemas aeróbios de tratamento de esgotos sanitários são amplamente utilizados e reconhecidos pela eficiência de tratamento em termos de remoção de matéria orgânica. Entretanto este tipo de sistema gera um subproduto (lodo) que tem preocupado cada vez mais, tanto pelo custo de tratamento quanto pelo aumento de sua geração, devido ao aumento do número de estações de tratamento que utiliza desse tipo de tecnologia

É necessário e urgente buscar alternativas para a crescente produção do lodo de esgoto. Alternativas como utilização do lodo na agricultura encontram restrições devido à quantidade de patógenos que podem estar presentes no lodo e o receio dos agricultores em utilizá-lo. Mesmo assim, para aplicar na agricultura é preciso tratar o lodo antes e transportá-lo até o seu destino, gerando os altos custos para a estação de tratamento.

É preciso buscar alternativas para redução da produção de lodos. Uma alternativa é a mudança do tipo de tratamento utilizando reatores anaeróbios, que são conhecidos por gerarem uma quantidade de lodo muito menor que os sistemas aeróbios. Entretanto a eficiência do tratamento é menor que os reatores aeróbios, e esses reatores 
não irão resolver o problema das estações de tratamento que utilizam sistemas aeróbios existentes e as estações em construção.

Uma alternativa que vem ganhando terreno é a minimização da geração de lodos através da desintegração do lodo (lise celular induzida) e seu retorno ao tratamento como fonte de alimento. Pesquisas indicam bons resultados do uso desses lodos principalmente na melhoria significativa do desempenho de digestores de lodo tratando o lodo desintegrado.

Para desintegração conta-se com o mais diversos tipos de equipamentos, tais como moinho de bolas, homogenizadores de alta pressão, tratamento alcalino, ozonização e ultra-som.

O presente trabalho estudou o tratamento de esgoto sintético em reatores seqüenciais em batelada, em escala de laboratório, com idades de lodo diferentes e, conseqüentemente, quantidades geradas de lodo diferentes, e retorno total do lodo gerado para o tanque de aeração após desintegração com ultra-som. 


\section{Objetivos}

O objetivo deste trabalho é verificar o comportamento de reatores seqüenciais em batelada aeróbios, com diferentes idades do lodo, aplicando a lise celular induzida no lodo em excesso e retornando o lodo ao tanque de aeração.

Objetivos específicos:

- Verificar a variação da DQO afluente dos reatores quando da adição da lise celular induzida;

- Efetuar um balanço de massa dos sistemas utilizados;

- Identificar as formas de nitrogênio e fósforo presentes no efluente;

- Verificar o comportamento dos nutrientes quando da adição do lodo desintegrado ao afluente;

- Quantificar a remoção de lodo com e sem a lise celular induzida;

- Verificar a influência da idade do lodo nas unidades de controle e teste;

- Propor alternativas de tratamento complementares, mediante o comportamento da remoção de nutrientes nos sistemas citados. 


\section{Revisão Bibliográfica}

O presente capítulo contempla uma breve revisão bibliográfica sobre o tratamento biológico de águas residuárias. Far-se-á uma pequena revisão do processo de lodos ativados, dando ênfase ao sistema em batelada, visto que o processo já está bastante difundido por meio de vários livros que discorrem sobre o tema.

Entretanto julga-se necessário dar mais ênfase ao tratamento do lodo gerado em sistemas biológicos de tratamento e, principalmente, o processo de desintegração celular e os meios para sua obtenção, já que a literatura nessa área ainda é escassa.

\subsection{Tratamento biológico de águas residuárias}

O tratamento biológico de águas residuárias, segundo Rojas (2000), implica na remoção de contaminantes mediante atividade biológica. Essa atividade remove principalmente substâncias orgânicas biodegradáveis, coloidais ou dissolvidas, da água residuária, mediante sua conversão em gases que escapam para a atmosfera e em biomassa extraída mediante sedimentação. Pode-se utilizar essa atividade também para remoção de nutrientes. Segundo Branco (1986), o tratamento resulta na transformação de seus constituintes em moléculas mais simples e estáveis. Trata-se da oxidação do material 
orgânico presente, transformando-o em substâncias de estrutura molecular simples e de baixo conteúdo energético.

À atividade biológica de remoção de matéria orgânica dá-se o nome de oxidação biológica, onde a forma orgânica é convertida em sua forma inorgânica altamente oxidada (dióxido de carbono, água, nitrato, ortofosfatos, sulfatos, nitrogênio gasoso, gás sulfídrico, etc.), como descritos na tabela 3.1.

Tabela 3. 1- Doadores e receptores de elétrons em ambiente aeróbio e anaeróbio

\begin{tabular}{ccccc}
\hline Ambiente & Doador & Receptor & Produtos & Processo \\
\hline \multirow{3}{*}{ Aeróbio } & Composto orgânico & $\mathrm{O}_{2}$ & $\mathrm{CO}_{2}$ e $\mathrm{H}_{2} \mathrm{O}$ & $\begin{array}{c}\text { Metabolismo } \\
\text { aeróbio }\end{array}$ \\
\cline { 2 - 5 } & $\mathrm{NH}_{4}^{+}$e $\mathrm{NO}_{2}^{-}$ & Oxigênio & $\mathrm{NO}_{2}^{-}, \mathrm{NO}_{3}^{-} \mathrm{e} \mathrm{H}_{2} \mathrm{O}^{-}$ & Nitrificação \\
\hline \multirow{3}{*}{ Anaeróbio } & Composto orgânico & $\mathrm{NO}_{3}^{-}$ & $\mathrm{N}_{2}$ e CO $\mathrm{CO}_{2}$ & \begin{tabular}{c} 
Desnitrificação \\
\cline { 2 - 5 }
\end{tabular} \\
\cline { 2 - 5 } & $\mathrm{H}_{2}$ e Acetato & $\mathrm{SO}_{4}^{-}$ & $\mathrm{H}_{2} \mathrm{O} e ~ S^{--}$ & $\begin{array}{c}\text { Redução de } \\
\text { sulfato }\end{array}$ \\
\cline { 2 - 5 } & $\mathrm{CO}_{2}$ & $\mathrm{CH}_{4}$ & Metanogênese \\
\hline
\end{tabular}

Fonte: Adaptado de Metcalf \& Eddy (1991) e Bailey \& Ollis (1986).

Segundo Rojas (2000), toda oxidação envolve a transferência de elétrons de uma substância reduzida, ou doadora de elétrons, a uma substância oxidante, ou aceptora de elétrons. A matéria orgânica é o alimento ou doador de elétrons para organismos vivos, bem como a amônia, acetato, hidrogênio a depender do ambiente em que se processa a atividade biológica, como exemplificado na tabela 3.1.

\subsection{Processo Aeróbio}

O processo aeróbio é um processo de respiração de oxigênio no qual o oxigênio livre é o único aceptor final de elétrons; o oxigênio é reduzido e o carbono é oxidado. Esse processo tem como objetivo obter energia necessária para síntese de tecido celular novo 
(Rojas, 2000). Esse metabolismo pode ser dividido em duas fases bem definidas, como citado por Van Haandel \& Marais (1999): catabolismo e anabolismo.

No catabolismo, ocorre a oxidação do material orgânico pelo oxigênio e a produção de compostos de baixo conteúdo energético. No anabolismo, ocorre a síntese do material celular. As equações (3.1) e (3.2) ilustram o metabolismo do processo aeróbio:

Catabolismo

CHNOS $+\mathrm{O}_{2} \quad \rightarrow \quad \mathrm{CO}_{2}+\mathrm{NH}_{3}+\mathrm{H}_{2} \mathrm{O}+$ outros produtos + energia (3.1) Matéria orgânica microrganismos

Anabolismo

$\underset{\text { Matéria orgânica }}{\mathrm{CHNOS}}+\mathrm{O}_{2}$ +energia $\quad \underset{\text { microrganismos }}{\mathrm{C}_{5} \mathrm{H}_{7} \mathrm{NO}_{2}}$ novas células

Pode-se observar que a matéria orgânica serve como fonte energética no catabolismo e como fonte material no anabolismo. Os processos de catabolismo e anabolismo são interdependentes: sem anabolismo a manutenção da vida dos microrganismos e, conseqüentemente, o próprio metabolismo desses seria impossível. Por outro lado, o anabolismo é um processo que requer energia e o microrganismo a obtém através da oxidação catabólica (Van Haandel \& Marais, 1999).

Entretanto, na ausência de matéria orgânica, o tecido celular respirará endogenamente e se converterá a produtos gasosos e energia para manutenção, como verificado na equação (3.3) (Rojas, 2000).

$$
\mathrm{C}_{5} \mathrm{H}_{7} \mathrm{NO}_{2}+5 \mathrm{O}_{2} \underset{\text { microrganismos }}{\rightarrow} 5 \mathrm{CO}_{2}+\mathrm{NH}_{3}+\mathrm{H}_{2} \mathrm{O}+\text { energia }
$$


Existem vários processos aeróbios para remoção de matéria orgânica entre os quais podem-se citar os processos de lodos ativados (convencional, mistura completa, aeração escalonada, alta taxa, oxigênio puro, etc.), lagoas aeradas, filtros de alta e baixa taxa, biodiscos.

\subsection{Lodos Ativados}

Dentre os processos citados o processo de lodos ativados é um dos mais utilizados no tratamento de esgotos domésticos. A utilização é explicada pelo sistema gerar um efluente de boa qualidade em reduzidos requisitos de área (Von Sperling, 1997).

O processo foi descoberto em 1914 na Inglaterra por Ardern e Lockett (Metcalf \& Eddy, 1991). O sistema baseia-se no princípio de se evitar a fuga descontrolada de bactérias ativas (lodo ativo) produzidas no sistema. Portanto é feita uma recirculação do lodo para manter a maior concentração de microrganismos ativos no reator aerado, a fim de acelerar a remoção do material orgânico das águas residuárias (Campos, 1994). O esgoto contém poucos microrganismos para permitir uma degradação/conversão rápida e eficiente. O processo de lodos ativados supera essa dificuldade mantendo uma grande quantidade de microrganismos presentes no tanque, acelerando o processo de degradação (Eikelboom, 2000).

\subsubsection{Microbiologia}

Os organismos mais importantes que participam do processo de lodos ativados são as bactérias, por serem responsáveis pela decomposição da matéria orgânica afluente. As bactérias usam a matéria orgânica para obter a energia necessária para o crescimento e 
manutenção da massa celular. Uma fração do material orgânico é oxidada a produtos de baixa energia $\left(\mathrm{NO}_{3}^{-}, \mathrm{CO}_{2}\right.$ e $\left.\mathrm{SO}^{2-}\right)$, enquanto uma outra fração é sintetizada como material celular (Metcalf \& Eddy, 1991).

Enquanto a comunidade de microrganismos no lodo ativado é dominada por bactérias aeróbias que requerem compostos orgânicos e energia (bactéria heterotróficas), existem também substanciais populações de fungos e protozoários. Bactérias nitrificantes que têm a habilidade de utilizar compostos inorgânicos para crescimento celular (bactérias autotróficas) estão presentes em quantidades variadas, dependendo do modo de operação e da quantidade de carbono e nitrogênio presentes. Rotíferos e nematóides são mais freqüentemente encontrados em sistemas com longos períodos de aeração ou com idades do lodo superiores a 10 dias (WEF, 1996).

Exames microscópicos regulares de lodo aeróbio servem para indicar ao operador as tendências do processo, associadas à eficiência de remoção de matéria orgânica e da sedimentação do lodo, adequação da aeração empregada, eventual presença de compostos tóxicos e ocorrência de sobrecargas orgânicas. Esses indicadores servem então para sugerir a realização de medidas físico-químicas ou mudança na operação do sistema, de tal forma que seja mantido o desempenho desejado (Vazoller, 1989). A tabela 3.2 Fornece os gêneros de microrganismos presentes em águas residuárias. 
Tabela 3.2 - Agrupamento de microrganismos de diversos gêneros

\begin{tabular}{ll}
\hline \multicolumn{1}{c}{ Grandes Grupos } & \multicolumn{1}{c}{ Gêneros Freqüentes } \\
\hline Classe Ciliata & \\
Ciliados livre-natantes & Paramecium, Colpidium, Litonotus, \\
Ciliados pedunculados & Trachelopyllum, Amphileptus, Chilodonella \\
& Vorticella, Operculária, $\quad$ Epistylis, \\
& Charchesium e as suctórias Acineta e \\
\hline Ciliados livres, predadores de floco & Podophyra \\
\hline Classe Mastigophora - flagelados & Aspidisca, Euplotes, Stylonychia, Oxytrichia. \\
\hline Classe Sarcodina - amebas & Euglena sp, Cercomona sp, Peranema \\
\hline Classe Rotífera - rotíferos & Amoeba, Arcella, Actinophrys, Vahlkampfi, \\
\hline Classe Nematoda - nematóides & Astramoeba, Difflugia, Cochilopodium \\
\hline Filo Anelida - anelídeos & Philodina, Rotaria, Epiphanes \\
\hline
\end{tabular}

Fonte: Vazoller (1998)

Entre os microrganismos encontrados em lodos ativados operando com esgotos domésticos, algumas espécies são consideradas indicadoras das condições de depuração do sistema de tratamento. A tabela 3.3 apresenta a correlação entre ocorrência ou predominância de certos microrganismos com a característica do processo biológico.

Tabela 3.3 - Microrganismos indicadores das condições de depuração

\begin{tabular}{|c|c|}
\hline Microrganismos & Característica do Processo \\
\hline Predominância de flagelados e rizópodes & $\begin{array}{l}\text { Lodo jovem, característico de } \\
\text { início de operação ou è è baixo }\end{array}$ \\
\hline Predominância de flagelados & $\begin{array}{l}\text { Deficiência de aeração, má } \\
\text { depuração e sobrecarga orgânica }\end{array}$ \\
\hline Predominância de ciliados pedunculares e livres & Boas condições de depuração \\
\hline Presença de Arcella (rizópode com teca) & Boa depuração \\
\hline Presença de Aspidisca costata (ciliado livre) & Nitrificação \\
\hline Presença de Trachelophyllum (ciliado livre) & $\grave{e ̀}_{C}$ elevado \\
\hline $\begin{array}{l}\text { Presença de Vorticella microstoma (ciliado } \\
\text { peduncular) e baixa concentração de ciliados livres }\end{array}$ & Efluente de má qualidade \\
\hline Predominância de anelídeos do gênero Aelosoma & Excesso de oxigênio dissolvido \\
\hline Predominância de filamentos & $\begin{array}{r}\text { Intumescimento do lodo ou } \\
\text { bulking filamentoso* }\end{array}$ \\
\hline
\end{tabular}




\subsection{Fluxo intermitente (Batelada)}

Uma variação do processo de lodos ativados é o processo de lodos ativados com fluxo intermitente ou batelada.

O princípio do processo, segundo Von Sperling (1997), consiste na incorporação de todas as unidades, processos e operações normalmente associadas ao tratamento convencional de lodos ativados em um único tanque (decantação primária, oxidação biológica e decantação secundária). Como se utiliza um tanque único, esses processos e operações passam a ser simplesmente sequiências no tempo e não unidades separadas como ocorre nos processos operacionais com fluxo contínuo. Como são seqüências no tempo, esses reatores são chamados também de Reatores Seqüenciais em Batelada (RSB). Essa será a forma como esses reatores serão mencionados de agora em diante.

Os reatores seqüenciais em batelada (RSB) são operados em regime de ciclos. Cada ciclo é composto por quatro fases distintas:

- Enchimento - É a etapa que envolve a adição do afluente ao reator. Geralmente o volume a ser colocado é igual ao volume a ser descartado na última etapa. A depender do tipo de tratamento, o enchimento pode ser acompanhado de mistura e aeração;

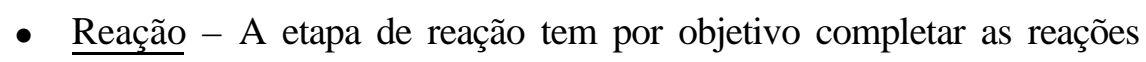
iniciadas durante o enchimento. O tempo de duração desta etapa varia de acordo com a composição e concentração do afluente, qualidade do efluente, concentração da biomassa e temperatura da mistura reacional; 


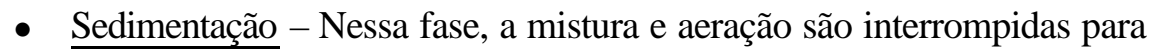
permitir clarificação do líquido. O tempo varia de acordo com a sedimentabilidade da biomassa;

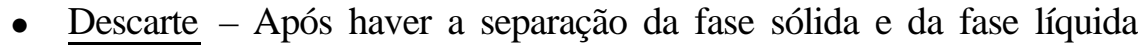
ocorre a etapa de descarte.

A depender do tempo de cada ciclo e das condições de operação, pode existir mais uma fase denominada repouso. Essa fase serve para ajustar o sistema de tratamento quando existem vários reatores em batelada.

Como o processo se dá ao longo do tempo e não do espaço como no sistema por fluxo contínuo, torna-se possível estabelecer, e variar, as condições de funcionamento do processo, sendo possível a otimização das diversas etapas, anaeróbia, anóxica e aeróbia, às condições específicas do esgoto que vai ser tratado. A figura 3.1 ilustra as fases de operação em um RSB.

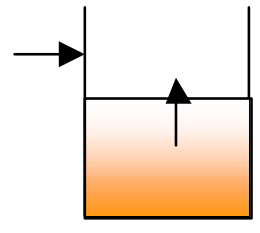

Enchimento

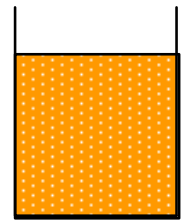

Reação

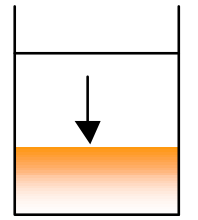

Sedimentação

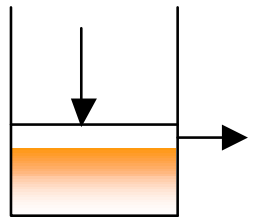

Descarte

Figura 3. 1- Etapas envolvidas na operação de um Reator Seqüencial em Batelada 
Segundo Droste \& Massé $^{1}$ apud Callado (2001), a operação de RSB tem demonstrado ser uma opção viável para sistemas de tratamento aeróbio e anaeróbio. Dependendo do tipo de efluente a ser tratado, o RSB apresenta vantagens e desvantagens:

\section{Vantagens:}

- Funcionam como tanque de equalização durante o período de enchimento;

- O sistema de aeração/agitação pode ou não ser ativado, dependendo da vazão do afluente a ser tratado. Com isso programa-se o sistema de modo a proporcionar menor consumo de energia;

- O sistema de bombeamento para recirculação do lodo é dispensável;

- Não perdem biomassa, caso ocorram choques hidráulicos.

Desvantagens:

- Falta de um equacionamento bem definido para projetar esses sistemas, assim como para definir procedimentos operacionais;

- Necessidade de equipamentos como, por exemplo, misturadores, válvulas de controle e controladores de tempo e de nível;

- Maior custo com obras civis, em razão de necessitar u maior volume de reator para tratamento em batelada.

Sobre a segunda desvantagem, o autor deve estar sugerindo que há a necessidade de vários equipamentos (misturadores, controladores de nível e de tempo) em

\footnotetext{
${ }^{1}$ DROSTE R. L.; MASSÉ, D. I. (1995). Anaerobic treatment in sequencing batch reactors. In: INTERNATIONAL SYMPOSIUM ON TECHNOLOGY TRANSFER. Preprints, Salvador, pp. 353 363.
} 
um só tanque, ao contrário de um tanque de aeração de um sistema de lodos ativados convencional. Isto acarretaria custos com implementação e manutenção. A presença de misturadores e controladores não chegaria a ser uma desvantagem se levar em conta que não vai se precisar de decantadores e nem bombas de transporte do lodo de retorno.

Van Haandel \& Guimarães (2000) citam que o problema de flotação no decantador secundário devido a desnitrificação pode ser contornado com o uso de RSBs, visto que, caso o lodo flote na etapa de sedimentação, o descarte poderá ser controlado para se evitar que o lodo flotado saia junto com o efluente.

\subsection{Remoção biológica de nitrogênio}

As principais etapas do ciclo do nitrogênio são: fixação de $\mathrm{N}_{2}$, assimilação do nitrogênio fixado, amonificação, nitrificação, desnitrificação e redução dissimilativa de compostos oxidados de nitrogênio. A assimilação é comum a todos os tipos celulares e as outras etapas são realizadas fundamentalmente por bactérias e, delas, a nitrificação e a desnitrificação são as mais relevantes do ponto de vista da descontaminação de efluentes que possuem compostos nitrogenados (Abreu, 1994).

O nitrogênio pode ocorrer sob várias formas no esgoto sanitário e sofrer diversas transformações durante o tratamento, como pode ser observado na Figura 3.2. Essas transformações permitem a conversão do nitrogênio amoniacal a produtos que podem ser facilmente removidos dos esgotos.

O nitrogênio pode ser removido de esgoto sanitário por meio de processos biológicos ou físico-químicos. Dentre as alternativas, os processos biológicos são os que 
oferecem custos relativamente baixos, quando comparados com os processos físicoquímicos (Metcalf \& Eddy, 1991).

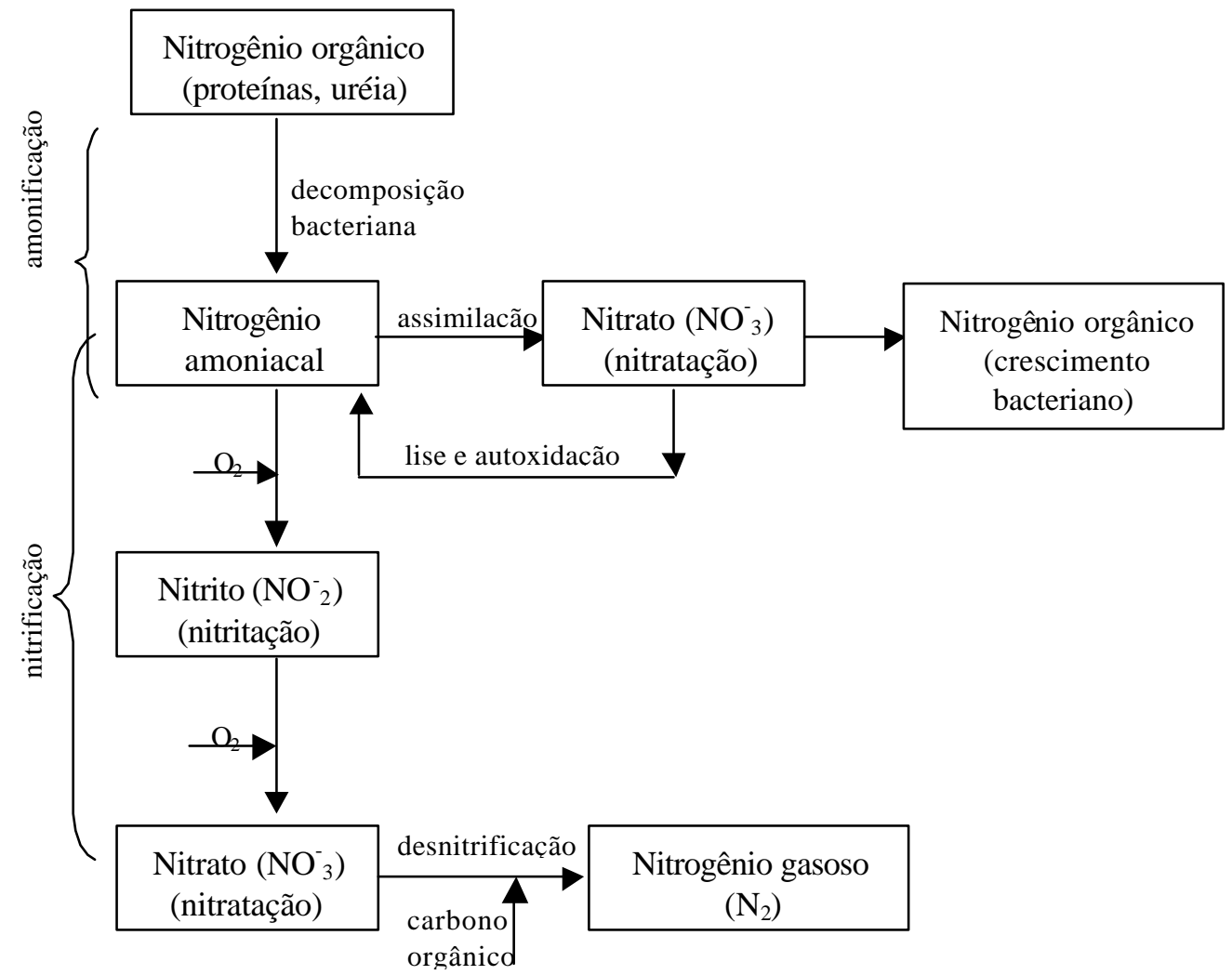

Figura 3. 2- Transformações do nitrogênio em processos biológicos de tratamento (adaptado de Metcalf \& Eddy, 1991)

Nitrificação é a conversão da amônia a nitrato por meio de ação bacteriana, na presença de oxigênio dissolvido, sendo realizada em duas etapas: nitritação (oxidação da amônia a nitrito pela ação das bactérias Nitrosomonas), seguido pela nitratação (oxidação do nitrito a nitrato pela ação das Nitrobacter). 
As bactérias nitrificantes são autótrofas e utilizam $\mathrm{CO}_{2}$ como fonte de carbono e o composto reduzido de nitrogênio como fonte de energia (Abreu, 1994). Jetten et al (1997) comentam que, embora as bactérias nitrificantes autótrofas sejam predominantes na natureza, a nitrificação pode também ocorrer pela ação de bactérias nitrificantes heterótrofas, como, por exemplo, Arthrobacer e Thiosphaera pantotropha. Os autores observaram que a Thiosphaera pantotropha não era apenas uma bactéria nitrificante heterótrofa, mas também uma desnitrificante aeróbia, ou seja, o organismo convertia a maior parte do nitrito diretamente em nitrogênio gasoso.

Dentre os fatores que influenciam a nitrificação, Abreu (1994) e Metcalf \& Eddy (1991) citam e comentam os seguintes:

- $\quad$ Relação C/N (carbono/nitrogênio) - A fração de organismos nitrificantes decresce à medida que a relação $\mathrm{C} / \mathrm{N}$ cresce. Em processos combinados de remoção de carbono e nitrogênio, essa relação é maior que 5 e, em processos de nitrificação em estágios separados, essa relação é menor que 3;

- Temperatura - A temperatura ótima para o crescimento de bactérias nitrificantes está na faixa de 28 a $36^{\circ} \mathrm{C}$;

- $\mathrm{pH}$ e concentração de amônia - Os vabres ótimos de pH para as Nitrosomonas e Nitrobacter se encontram na faixa de 7 a 9 . O valor do $\mathrm{pH}$ influencia na concentração do íon amônio, afetando a nitrificação. O íon amônio e ácido nitroso não dissociado são tóxicos para as bactérias nitrificantes, a partir de certos valores;

- Oxigênio dissolvido (OD) $-O$ oxigênio é utilizado pelas bactérias nitrificantes nas reações de oxidação. De acordo com Abreu (1994), as Nitrobacter parecem 
apresentar maior sensibilidade que as Nitrosomonas, em baixas concentrações de OD $(0,5 \mathrm{mg} / \mathrm{L})$.

\subsection{Geração de lodo}

Segundo Campos (1994), apesar dos esgotos sanitários brutos serem compostos por apenas $0,1 \%$ de sólidos, a produção de lodo nas Estações de tratamento de esgotos (ETEs) é muito grande, principalmente quando o tratamento utilizado é aeróbio, o qual produz cerca de três vezes ou mais lodo que o tratamento anaeróbio. Levantamentos feitos em vários países indicam que o volume de lodo produzido em uma ETE representa cerca de $1 \%$ a $2 \%$ do volume do esgoto tratado, porém o custo do tratamento e disposição final do lodo chega a atingir entre $30 \%$ e $50 \%$ do custo operacional de uma ETE (Luduvice, 1998). Spellman (1997)² apud Miki et al. (2001), complementa que a fase sólida de tratamento, além de ser responsável por $40 \%$ dos custos de implantação e $50 \%$ dos custos de operação, é responsável por $90 \%$ dos problemas operacionais.

Mendonça (1993) observa que os custos das unidades para estabilização, desidratação e disposição do lodo representam, aproximadamente, um terço do investimento total em uma estação de tratamento de esgotos. Dependendo do sistema empregado, o custo das unidades de processamento de lodo poderá ser até maior do que o custo dos equipamentos para tratamento da fase líquida. Por isso é essencial que se tenha um sistema de disposição de lodo bem projetado e operado.

${ }^{2}$ SPELMAN, F. R. (1997). Dewatering Biosolids. Technomic Publishing Company, Inc. 
A quantidade e qualidade do lodo em excesso dependem da vazão e da natureza da água residuária, da configuração do sistema de tratamento e das condições operacionais.

No caso de haver tratamento de esgoto em um sistema com sedimentação primária, a produção de lodo é bem maior que no caso quando o esgoto bruto é direcionado diretamente ao tanque de aeração no sistema de lodos ativados (Van Haandel \& Marais, 1999).

Segundo Van Haandel \& Marais (1999), o lodo exibe basicamente três aspectos indesejáveis:

- Instabilidade biológica: A alta fração de material orgânico biodegradável torna o lodo putrescível;

- A qualidade higiênica do lodo é péssima, tendo uma grande variedade de vírus, bactérias e parasitas que constituem uma ameaça para a saúde pública;

- A concentração de sólidos suspensos é baixa, de modo que o volume do lodo de excesso é grande.

Segundo Fernandes (1997), considerando uma produção média de lodo para os sistemas de tratamento aeróbios de $17,5 \mathrm{~kg} /$ ano em base seca por equivalente habitante, tem-se para cada 100.000 habitantes urbanos uma produção de 4,8t/dia de lodo seco ou 24 t/dia de lodo pastoso ( $80 \%$ de umidade). Ainda segundo esse mesmo autor, comparando com a produção per capita de resíduos sólidos domiciliares $(0,6 \mathrm{~kg} / \mathrm{dia})$, para 
uma cidade tratando integralmente seus esgotos, a produção de lodo pastoso atingiria, em peso, aproximadamente $40 \%$ do total de resíduos sólidos domiciliares.

Segundo a EPA (1999)³ apud Andreoli \& Pinto (2001), nos Estados Unidos a produção de lodos no ano 2000 foi estimada em 7,1 milhões de toneladas, devendo chegar a 8,2 milhões de toneladas em 2010. Na Europa, a produção atual de 8,9 milhões deverá alcançar 10,1 milhões em 2005, decorrente dos grandes investimentos na expansão desses serviços (Davis \& Hall, $1997^{4}$ apud Andreoli \& Pinto, 2001)

Andreoli \& Pinto (2001) comentam também que a produção de lodo no Brasil atualmente está estimada entre 150 mil a 200 mil toneladas por ano (base seca). Citam ainda que há uma pressão da sociedade por melhores condições ambientais devido aos baixos índices de coleta e tratamento de esgoto. Assim haverá uma tendência de ocorrer um aumento substancial na quantidade de lodo a ser disposto na próxima década. Como a população urbana está estimada em 116 milhões e apenas 32 milhões têm seu esgoto coletado, se houvesse um tratamento de todo o esgoto coletado haveria um incremento na produção de lodo de 325 mil a 473 mil toneladas por ano.

Santos \& Tsutiya (1997) previram, para 2005, produção diária de 575 toneladas de lodo seco gerado somente na Região Metropolitana de São Paulo (RMSP) pelas principais ETEs operadas pela SABESP (Companhia de Saneamento de São Paulo), que em sua maioria utilizam o processo aeróbio para degradação biológica da matéria orgânica.

${ }^{3}$ ESTADOS UNIDOS. Environmental Protection Agency (1999). Biosolids Generation, use and Disposal in the United States. (EPA 530-R-99-009).

${ }^{4}$ DAVIS, R. D.; HALL, J. E. (1997). Production, Treatment and Disposal of Waste Sludge in Europe from a UK Perspective. European Water Pollutioin Control, v. 7, n. 2. 
A tabela 3.4 apresenta previsão de produção diária de lodo na Região Metropolitana de São Paulo de acordo com cada estação de tratamento.

Tabela 3.4 - Previsão da produção diária de lodo em 2005

\begin{tabular}{ccc}
\hline ETE & Tipo de Tratamento & $\begin{array}{c}\text { Produção de lodo } \\
\text { base seca (t/d) }\end{array}$ \\
\hline Barueri & Lodos Ativados Convencional & 227 \\
\hline ABC & Lodos Ativados Convencional & 85 \\
\hline Suzano & Lodos Ativados Convencional & 27 \\
\hline Parque Novo Mundo & Lodos Ativados Convencional & 166 \\
\hline São Miguel & Lodos Ativados Convencional & 55 \\
\hline Franco da Rocha & Filtro Biológico & 9 \\
\hline Perus & Filtro Biológico & 6 \\
\hline & & 575
\end{tabular}

Fonte: Santos \& Tsutiya (1997)

Além Sobrinho (2001) comenta que com o decorrer do tempo de operação

das ETEs, com o aumento da geração do lodo e o esgotamento da capacidade das soluções provisórias de continuar recebendo lodo, como atualmente vem ocorrendo em relação a várias ETEs já implantadas no Brasil, soluções de mais longo prazo e mais adequadas para disposição desses resíduos sólidos passam então a receber maior atenção dos técnicos e das autoridades envolvidas com o controle do meio ambiente. Assim, a solução do problema do lodo gerado no tratamento da fase líquida do esgoto é tão ou mais complexa do que o tratamento do esgoto propriamente dito. O mesmo pensamento é compartilhado por Miki et al. (2001), que citam que essa crescente produção de lodo tem levado ao desenvolvimento de novas tecnologias de modo a atender aos requisitos ambientais, de segurança e saúde pública cada vez mais restritivos. 
No Brasil, o gerenciamento do lodo tem sido negligenciado. Os projetos de estações de tratamento de esgotos raramente detalham a forma de gerenciamento e disposição final do lodo, justamente a etapa mais cara e complexa de um sistema de tratamento. Segundo Fernandes et al. (2001), é muito comum que os projetos contenham o desenho de um caminhão e uma seta indicando a palavra: "disposição final adequada". Desta forma, a gestão tem sido realizada sem planejamento e muitas vezes em condições emergenciais pelos operadores das estações. Ainda cita que ainda é bastante comum o lançamento de lodo nos corpos receptores, comprometendo os benefícios do investimento realizado nos sistemas de coleta e tratamento.

Segundo Fernandes e Souza (2001), a gestão do lodo produzido por uma estação de tratamento de esgotos é um dos maiores desafios para o sucesso técnico e operacional de um sistema. Por isso é necessário que os objetivos de estabilização do lodo em um determinado sistema sejam definidos ainda na fase de projeto da estação e fixado de acordo com o destino final previsto para o lodo.

Os autores complementam que as fases de adensamento (se necessárias), estabilização e desidratação devem ser compatíveis entre si e coerentes com o destino final a ser dado ao lodo. Se o destino for o uso agrícola, o nível de patógenos e o seu potencial de geração de odores são de extrema importância. Caso o destino final seja a incineração, as exigências serão muito menores.

Quando a análises de alternativas de processamento e destino final é feita sob a ótica de uma política sustentável, há automaticamente uma hierarquização das alternativas. Neste caso, segundo Fernandes et al. (2001), deve haver uma preocupação no sentido de: 
- Diminuir a produção, utilizando-se tecnologias de tratamento de esgotos que produzam menor quantidade de lodo. Embora vários tipos de tratamento de esgotos apresentem variações na produção de lodo, a margem de manobra nesse ponto é limitada, pois quanto melhor a qualidade do esgoto tratado, maior será a quantidade do lodo produzido;

- Produzir lodo de melhor qualidade, através da definição de critérios para recebimento de esgotos industriais na rede coletora pública, principalmente no que se refere ao seu conteúdo de metais pesados garantindo a produção de um lodo compatível com seu uso agrícola;

- Reciclar ao máximo o lodo produzido. Neste caso o uso agrícola é a alternativa mais utilizada no mundo, juntamente com a recuperação de áreas degradadas, pastagens e silvicultura.

Muitos países já reconheceram que a disposição em aterros não é uma prática sustentável, apresentando a cada dia maiores custos em função de maiores distâncias e do atendimento às crescentes restrições ambientais. Estes fatores, associados as políticas de estímulo a reciclagem, definem uma clara tendência no uso de aterros sanitários especificamente para resíduos não recicláveis. A tabela 3.5 apresenta as principais tendências na gestão do lodo de esgoto nos Estados Unidos e Europa. 
Tabela 3. 5 - Tendências de gerenciamento de lodo ns Estados Unidos e Europa

\begin{tabular}{|c|c|c|}
\hline Processos & Estados Unidos & Europa \\
\hline Produção de lodo & Crescente & Crescente \\
\hline Processos mais eficazes de secagem & Crescente & Crescente \\
\hline $\begin{array}{l}\text { Processos mais avançados de beneficiamento } \\
\text { e higienização }\end{array}$ & Crescente & Crescente \\
\hline Reciclagem de esgoto & Crescente & Crescente \\
\hline Disposição em aterros & Decrescente & Decrescente \\
\hline Incineração & Decrescente & Crescente \\
\hline Disposição oceânica & Banido & Decrescente \\
\hline Exigências legais & Crescente & Crescente \\
\hline Níveis de metais no biossólido & Decrescente & Decrescente \\
\hline Eficiência energética e recuperação de energia & Crescente & Crescente \\
\hline Terceirização na gestão de biossólidos & Crescente & Crescente \\
\hline Custos da gestão de biossólidos & Crescente & Crescente \\
\hline $\begin{array}{l}\text { Exigências da sociedade em relação as } \\
\text { condições ambientais }\end{array}$ & Crescente & Crescente \\
\hline $\begin{array}{l}\text { Exigência dos agricultores em relação à } \\
\text { qualidade dos biossólidos }\end{array}$ & Crescente & Crescente \\
\hline
\end{tabular}

Fonte: Fernandes et al. (2001)

Nota-se claramente que, com a produção crescente de lodos, há uma tendência para processos mais eficazes no tratamento do lodo visando melhorar sua qualidade e visando reduzir a quantidade disposta em aterros e outros locais de disposição. Nota-se também um crescimento nas exigências legais e da sociedade nos quesitos reciclagem e padrões ambientais. 
O termo biossólido é utilizado para identificar o lodo proveniente de estações de tratamento de esgotos sanitários e processados de modo a permitir o seu manuseio de forma segura na utilização agrícola.

Como o lodo de esgoto é definido como resíduo sólido, cabe aqui a aplicação dos 3Rs muito difundido no caso do lixo nosso de cada dia: Reduzir, Reutilizar e Reciclar. O conceito reduzir ainda é pouco difundido no caso do lodo de esgoto. Geralmente é aplicado o conceito de reciclagem, como o caso da aplicação de biossólidos na agricultura.

Gonçalves e Luduvice (2000) citam que a produção de lodo de esgoto pode ser minimizada na fase líquida do tratamento, por meio de seleção, quando possível, de processos que produzam pouco lodo. No caso de processos biológicos, os autores comentam que a quantidade de lodo dependerá das condições impostas aos reatores e será tanto menor quanto mais longa for a idade dos lodos, e maior for a presença de microrganismos com baixa taxa de crescimento na biomassa ( $\hat{1}_{\text {máx }}$ pequeno). No caso de processos biológicos mais antigos, com biomassa em suspensão (lodos ativados), estes pré-requisitos podem representar um significativo impacto nos custos de implantação e operação de futuras ETEs, porque demandam grandes volumes reacionais, carga orgânica pequena, suprimento considerável de energia e boa retenção de biomassa.

A citação dos autores acima relacionados vem ao encontro da afirmação de Matthews (1992) que comenta que o uso de processos de tratamento de esgotos com menor produção de lodo devem ser estimulados. Rogalla (1998) comenta que existem outras tecnologias recentes de tratamento com menor produção de lodo, tais como 
destruição mecânica do lodo para hidrolisar matérias sólidas; oxidação/ozonização do lodo de retorno para destruir matérias orgânicas; suporte de biomassa fixa para aumentar os sólidos e cultivar organismos, e biorreator com membranas que permitem alta concentração de lodo e pequena carga específica. Puhler \& Stadler (1993) citam que a destruição mecânica das células (lise celular induzida) solubilizam uma grande quantidade de produtos presentes nas células com máxima atividade biológica; evitam alteração secundária dos produtos, tais como desnaturação, oxidação; melhoram a performance das etapas de separação sólido/líquido. Certamente uma nova filosofia nos projetos de estações de tratamento de esgotos está se desenvolvendo, visando atingir melhor qualidade do efluente com menor quantidade de lodo a ser descartada.

Diante do exposto, tem-se a necessidade de se utilizar tecnologias que busquem uma menor produção de lodos nestes sistemas.

\subsection{Lise Celular Induzida}

Segundo Metcalf \& Eddy (1991), a lise celular é o fenômeno que ocorre durante a fase endógena do crescimento bacteriano, na qual os nutrientes remanescentes das células mortas se difundem no meio, alimentando as células remanescentes. A aceleração desta etapa do crescimento microbiano pode ser realizada por várias maneiras visando um tratamento do lodo.

A lise celular induzida tem como objetivo acelerar o processo natural de lise celular, visando a desintegração da célula e utilizando-as como fonte de alimentação. Os processos de desintegração celular, segundo Bomberg \& Kramer (1988), podem ser 
classificados como físicos (principalmente mecânico), químicos e biológicos, como detalhados na figura 3.3.

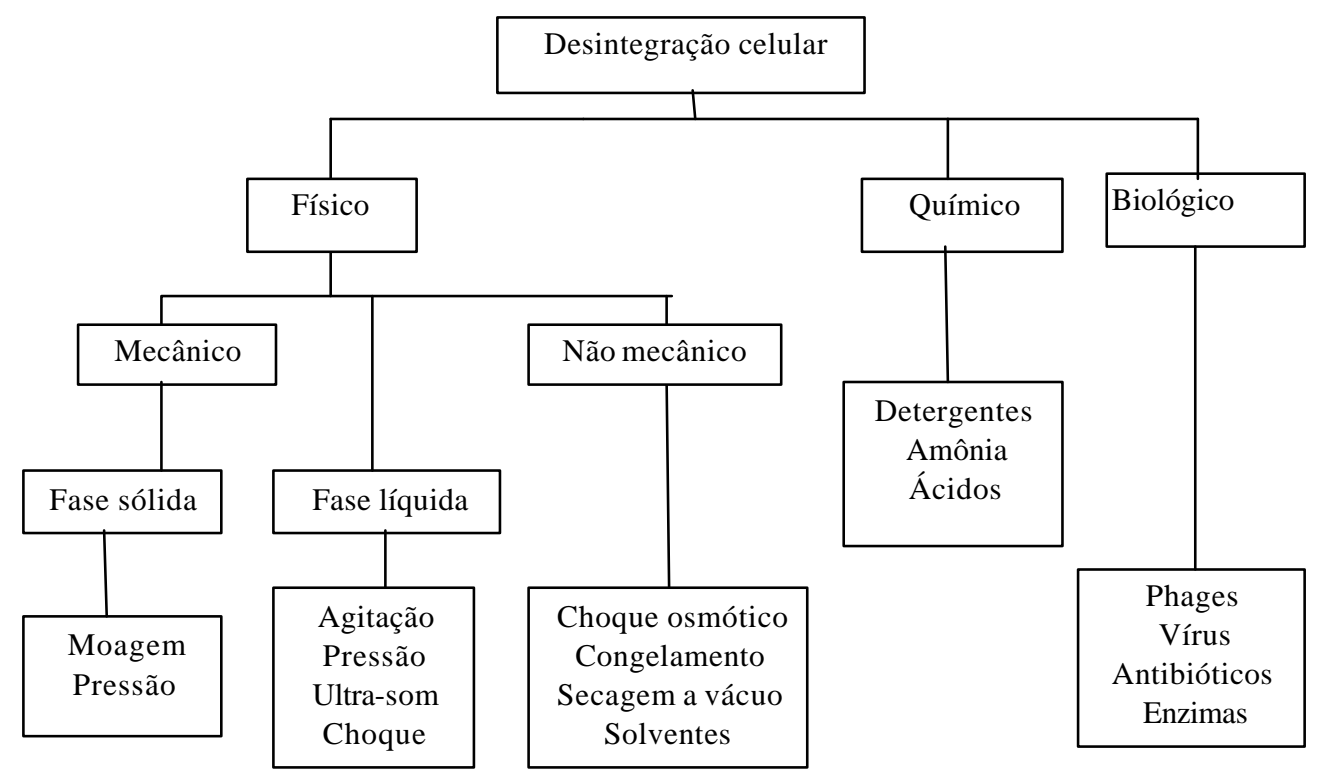

Figura 3. 3- Métodos de desintegração (Bomberg \& Kramer,1988).

Outra classificação para desintegração celular é fornecida por Neis (2000), especificamente para o tratamento de lodo de esgoto. Os métodos são divididos em:

- Mecânicos: Moinho de bolas, homogeneização a alta pressão, homogeneização;

- Elétricos: Descarga elétrica;

- Térmicos: Pirólise;

- $\quad$ Térmico-biológicos: Digestão aeróbia;

- Químicos: Reações ácido/base;

- Biológicos: Adição de enzimas;

- Acústico: Cavitação-Reações sonoquímicas. 
Muller (1998) e Dohányos et al. (1997) comentam que a lise induzida do lodo acelera o processo de digestão anaeróbia do mesmo, aumentando a biodegradabilidade anaeróbia dos materiais orgânicos tratados, a produção de metano, e produzindo uma menor quantidade de lodo digerido melhorando o balanço energético do processo e diminuindo, assim, o tamanho do digestor. O mesmo princípio é válido para digestores aeróbios.

Lawson (1993), estudando digestores anaeróbios em batelada com aplicação de um desintegrador mecânico para diminuir o tamanho dos grânulos no digestor, conseguiu uma redução no teor de sólidos totais de $60 \%$ e sólidos voláteis de $69 \%$. Essa redução no teor de sólidos foi melhor que a redução observada no reator controle: redução de $50 \%$ no teor de sólidos totais e redução de $60 \%$ no teor de sólidos voláteis.

Pode-se aplicar também o lodo lisado como fonte de carbono para o processo de desnitrificação removendo nutrientes, diminuindo, assim, a sua produção final e diminuindo os conseqüentes custos com tratamento e transporte.

Lin et al. (1998) aplicaram hidrólise alcalina, concentrações de 10 a 50mg/l de $\mathrm{NaOH}$, a um lodo de uma planta de tratamento de uma indústria petroquímica que continham altas concentrações de nitrogênio, para verificar a possibilidade de uso deste lodo como fonte de carbono em uma etapa de desnitrificação. Os autores concluíram que a hidrólise alcalina transformou compostos, antes complexos e biorefratários, em fonte de carbono melhorando assim a etapa de desnitrificação do sistema.

Em estudos realizados por Higgins \& Springer (1998), operando uma estação de tratamento de esgoto em Portland, Maine - USA, com uma vazão diária de $56.870 \mathrm{~m}^{3} / \mathrm{d}$ e 
com lise celular induzida por meio de cisalhamento, os autores obtiveram uma redução da geração do lo do da ordem de $60 \%$ (de $2743 \mathrm{~kg} / \mathrm{dia}$ para $1109 \mathrm{~kg} / \mathrm{dia}$ ). Os autores ainda citam que a aplicação da lise resultou em uma redução de 8,2 toneladas de lodo úmido a serem descartados diariamente. Com isso, menos lodo foi desaguado resultando em uma economia de energia com a redução da utilização de filtros-prensa, bombeamento do lodo, adensamento, aplicação de polímeros. Além disso, houve uma melhora na sedimentação e formação de um lodo mais compacto.

Nolasco et al. (2001) operando um reator de bancada tratando efl uentes de indústria de Papel \& Celulose, empregando a lise celular induzida por meio de cisalhamento no lodo em excesso gerado no processo de lodos ativados e recirculando totalmente o lodo, conseguiram boas eficiências de remoção de compostos organoclorados sem prejudicar a eficiência do tratamento. $\mathrm{O}$ estudo compreendeu duas fases: a primeira fase durou 112 dias quando foi avaliado o comportamento do sistema de lodos ativados tratando um efluente simulado de indústria de celulose não branqueada. À fase II do estudo foram acrescentados compostos clorofenólicos ao efluente sintético simulando uma indústria de celulose branqueada. Essa fase teve a duração de 85 dias e foi dividido em cinco períodos de aproximadamente 16 dias cada. Em cada período foi aumentada a concentração de compostos organoclorados e metanol no afluente do sistema. Os autores obtiveram uma remoção em termos de DQO de $69 \%$ para o reator tratando o lodo com lise, contra $71 \%$ do reator controle. A remoção de organoclorados, medidos como Ácidos Orgânicos Adsorvíveis (AOX), foi de 85\% para o sistema com lise, e de $86 \%$ para o reator de controle. 


\subsubsection{Ultra-som}

O som pode ser definido simplesmente como uma vibração. Todos os sons são produzidos por coisas que vibram e todas as coisas que vibram geram um som, sendo que, o nível de uma vibração determina o seu alcance. O nível mais baixo de vibração tem um alcance mais baixo e o nível mais alto tem um alcance mais alto. Portanto, o alcance está diretamente ligado àtaxa de vibração.

Quando esta taxa de vibração, ou ciclo, é expressa por unidade de tempo (segundos), é chamada de freqüência. Geralmente a frequiência é expressa em Hertz (hz) que é o número de ciclos por segundo, por exemplo: $1 \mathrm{hz}=1$ ciclo por segundo. A maior parte dos homens podem ouvir sons de $10 \mathrm{hz}$ a $16.000 \mathrm{hz}$ (16 khz), porém algumas mulheres podem ouvir até $19.000 \mathrm{hz}(19 \mathrm{khz})$, portanto, sons que ultrapassem esta taxa de frequiência não podem ser ouvidos pelo ouvido humano. Por este fato, que frequiências acima de 20.000 hz (20 khz) são chamadas de Ultra-Som. Enquanto freqüências acima de 20.000 hz (20 khz) não são usadas para comunicação oral entre seres humanos, são usadas em uma vasta aplicação de equipamentos que facilitam a vida do homem.

A primeira aplicação comercial é datada do início do século 20 quando foi utilizado para medir a profundidade da água, por meio do eco, em um equipamento conhecido como sonar (Mason, 1999). Depois disso uma grande variedade de aplicações foram desenvolvidas, desde a detecção de falhas em materiais, imagens em medicina, detectores de cardumes de peixe, máquinas para localização de trincas em peças metálicas, equipamentos de solda em termoplásticos e metais, separadores de células. 
Se for aplicada uma alta energia acústica a um sistema líquido, é possível gerar reações químicas e físicas que podem modificar as características das substâncias particuladas e dissolvidas presentes no líquido (Neis \& Tiehm, 1999). Em alta intensidade acústica, particularmente em faixas de freqüência médias e baixas, há a geração de bolhas de gás que, segundo Neis (2000), variam de tamanho de acordo com a onda acústica até que finalmente entram em colapso (cavitação). A figura 3.4 apresenta o exato momento em que uma bolha começa o processo de implosão

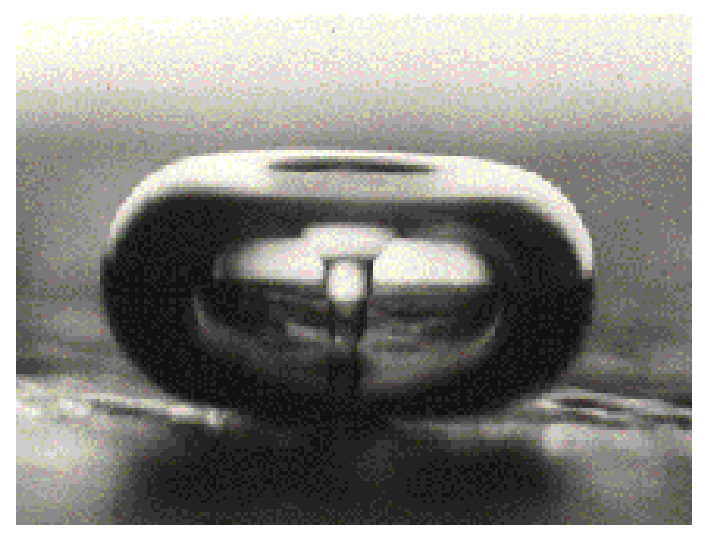

Figura 3. 4- momento de implosão de bolha submetida ao ultra-som (Berliner, 1999) University of Washington, Applied Physics Laboratory (Lawrence Crum, Ph.D.) (Diâmetro da bolha - aproximadamente $1 \mathrm{~mm}$ )

Após a cavitação a temperatura e pressão do gás atingem valores de $5000 \mathrm{~K}$ e 500bar, respectivamente. A figura 3.5 ilustra o processo de formação e cavitação de uma bolha submetida ao ultra-som.

Sob estas condições de temperatura e pressão (devido ao colapso adiabático), são originadas reações sonoquímicas (reações até agora impossíveis de obtenção por meios tradicionais) no meio, as quais levam a formação de radicais altamente reativos $\left(\mathrm{H}^{\bullet}\right.$ e OH•) e ruptura térmica de substâncias (Neis \& Tiehm, 1999). A formação dos radicais, 
segundo Portenlänger (1999), é devido a homólise do vapor d'água em radicais $\mathrm{H} \bullet \mathrm{e} \mathrm{OH} \bullet$ sob tais condições.

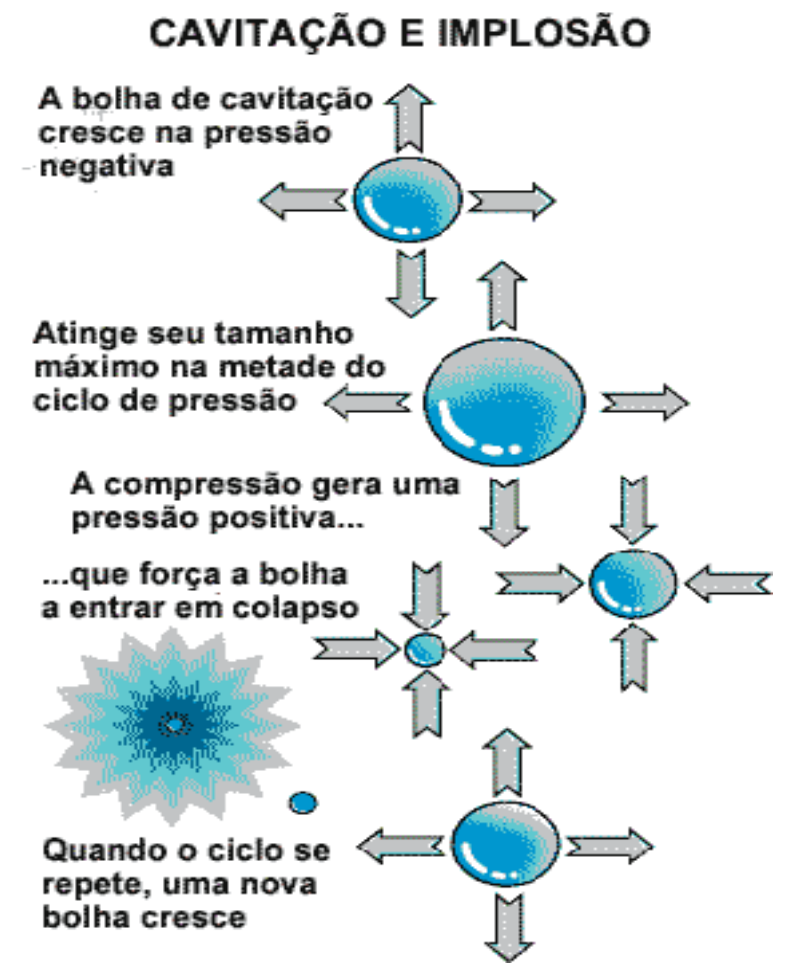

Figura 3. 5- Esquema de implosão de uma bolha (Thorton, 2002)

As bolhas são preenchidas por vapor e envoltas por um líquido hidrofóbico na camada limite. Por essa razão, há a preferência de acúmulo de substâncias voláteis e hidrofóbicas nas bolhas, onde elas estão expostas a reações pirolíticas e de radicais. Alguns desses radicais escapam do vapor, alcançam a camada limite líquida e vão para o meio líquido e reagem com substâncias hidrofílicas (Neis \& Tiehm, 1999). A figura 3.6 ilustra o processo de formação dos radicais $\mathrm{H} \bullet$ e $\mathrm{OH} \bullet$. 


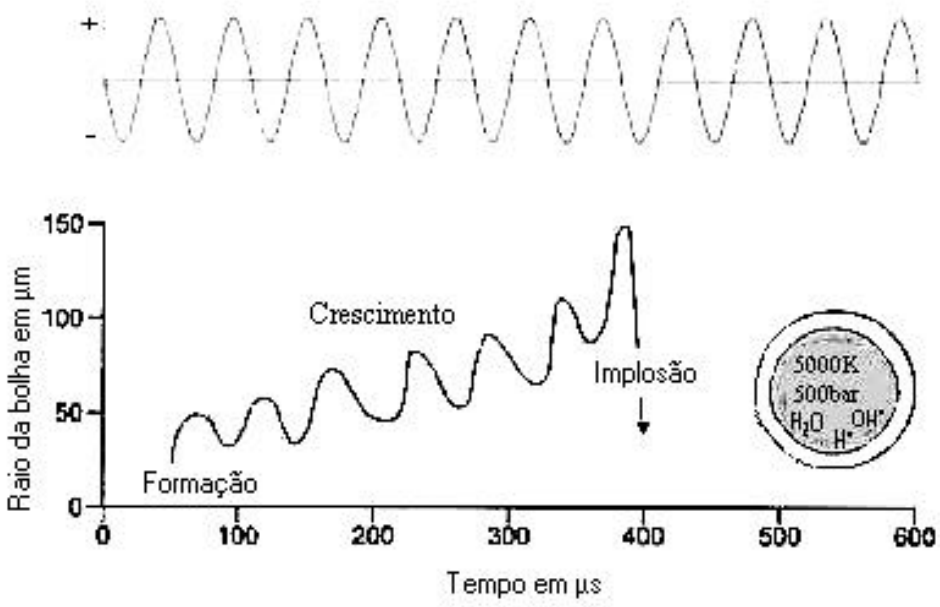

Figura 3. 6- Processo de formacão de radicais após aplicacão de ultra-som (Neis. 2000)

As aplicações do ultra-som podem ser divididas em duas correntes distintas: ensaios não destrutivos e ensaios destrutivos. Os ensaios não destrutivos são aplicações do ultra-som em frequiências altíssimas (acima de 3Mhz), pois a essa freqüência ão foi possível ainda gerar uma potência capaz de causar cavitação (colapso das bolhas produzidas). Geralmente é empregado o ultra-som nessa freqüência para diagnósticos médicos.

Existe uma ampla gama de aplicação do ultra-som para ensaios destrutivos e uma ampla faixa de freqüência (de 20khz a 3Mhz). Segundo Berliner (1999), algumas das mais importantes aplicações são:

- Sonoquímica: Geração de novas espécies até agora impossíveis de obtenção por meios clássicos, como calor, eletricidade, luz e catálise; 
- Aceleração de reações: A cavitação acelera reações químicas e físicas, como as de surfactantes e detergentes. Motivo pelo qual o ultra-som é utilizado para limpeza de materiais, principalmente em laboratórios;

- Beneficiamento de minérios e minerais: Melhora a flotação e extração de minérios e minerais, tais como o carvão;

- Dispersão de partículas finas: Melhora a análise de distribuição de partículas; melhora as pastas de cerâmica utilizadas para isolamento de capacitores eletrônicos e porcelanas; tornam mais resistente ao desgaste as ferramentas sinterizadas de cerâmicas;

- Homogeneização: Torna as misturas e suspensões mais uniformes para biotecnologia e processamento de polpa de papel;

- Emulsificação: Processamento de alimentos, remédios, e cosméticos;

- Dissolução: Dissolve sólidos em solventes; acelera o controle de qualidade de remédios, sabores e fragrâncias;

- Desgaseificação: Remove gases de soluções sem aplicação de vácuo ou calor; controle de qualidade em vinhos e bebidas carbonatadas;

- Limpeza de superfícies e materiais porosos: Limpa a superfície dos óxidos e outros filmes, emulsifica camadas de óleos, suspende particulados, melhora a aplicação de detergentes e remove gorduras sem aplicação de solventes à base de hidrocarbonetos. 
No campo ambiental, as aplicações do ultra-som podem ser descritas segundo Mason (1999):

- Descontaminação biológica: Melhora a eficiência da descontaminação se aplicado a outros métodos convencionais de esterilização: biocidas e temperatura. Somente a aplicação do ultra-som torna o processo muito caro, em termos industriais, para atingir o mesmo grau de descontaminação. Dentre os métodos de descontaminação biológica, pode-se destacar os seguintes:

1. Descontaminação de superfícies: É a mais conhecida de antiga aplicação do ultra-som no campo ambiental. O ultra-som causa o desalojamento da bactéria junto à superfície do material a ser limpo. A maior vantagem é que o ultra-som alcança fendas na superfície do material que não seriam alcançadas por métodos tradicionais de tratamento;

2. Esterilização da água: O ultra-som é aplicado para se diminuir a quantidade de compostos utilizados na desinfecção (compostos de cloro e ozônio) visando uma redução nos custos em escala industrial;

3. Esterilização de gêneros alimentícios: Têm sido feitos esforços para esterilização de gêneros alimentícios utilizando as técnicas comumente aplicadas (térmicas) juntamente com a irradiação ultra-sônica. Esse processo vem sido denominado de termosonicação;

4. Extermínio de algas: As algas e plânctons, ao contrário das bactérias, são facilmente destruídas com a aplicação do ultra-som. Nesses casos não são necessárias aplicações de biocidas. 
- Descontaminação química: O ultra-som pode ser utilizado para remediação química da água. A maneira de atuação do ultra-som na degradação de poluentes orgânicos vai depender das suas características físicas e químicas. Isso se deve ao fato de existirem duas maneiras de ação da bolha na cavitação: Se o composto químico estiver dentro da bolha, a sua destruição ocorrerá devido às extremas cond ições geradas no colapso; entretanto se o composto estiver na fase líquida, a bolha agirá como fonte de radicais $\left(\mathrm{H}^{\circ}, \mathrm{HO}^{\bullet}\right.$ e $\left.\mathrm{HOO}^{\circ}\right)$ que reagirão com os poluentes, mudando suas características.

Mais especificamente no campo de tratamento de água, Phull et al. (1997) citam os usos potenciais para aplicação de ultra-som:

- $\quad$ Biotecnologia : Melhoramento da atividade enzimática;

- Descontaminação: Melhoramento dos processos de coagulação e flotação; destruição de contaminantes químicos e biológicos; destruição de PCB's, hidrocarbonetos clorados e pesticidas;

- Desgaseificação: Remoção do excesso de cloro; remoção do excesso de ozônio; remoção de metano;

- Desaguamento: Melhoramento da eficiência em processos de digestão; desaguamento de lodos e pastas;

- Desinfecção: Desinfecção geral de água de abastecimento; destruição de microrganismos específicos como crystoporidium e giardia; melhora a eficiência de bactericidas e desinfetantes; melhora o tratamento por ultravioleta por meio da 
quebra de partículas e limpeza dos tubos de UV; desinfecção de bactérias patogênicas no lodo de esgoto;

- Dispersão: Desaglomeração de partículas; redução do tamanho de partículas; quebra de flocos de bactérias; homogeneização de misturas para tratamento posterior; dispersão de químicas utilizadas mo tratamento; emulsificação; mistura;

- Filtração: Melhoramento da eficiência dos filtros e membranas;

- Oxidação: Melhoramento dos processos de oxidação por meio da melhora na mistura.

Phull et al. (1999), citam que os tratamentos convencionais de água podem não remover todas as impurezas, tais como partículas finas que prejudicam a eficiência de radiação ultravioleta, e a presença de esporos que podem ficar aglomeradas prejudicando a eficiência de uma cloração. Os autores estudaram combinações de ultra-som com tratamentos convencionais e concluíram que a aplicação do ultra-som, quebrando as partículas e rompendo flocos e membranas, melhorou a eficiência da cloração e ozonização. Como o ultra-som também promove a desgaseificação, pode ser aplicado mais cloro no fim do tratamento e depois aplicar o ultra-som para retirada do excesso.

Blume et al. (2002), estudando a aplicação do ultra-som com ultravioleta na desinfecção de um efluente de tratamento de água residuária, concluíram que o uso do ultra-som por 5 minutos seguido por aplicação de ultravioleta por 5 segundos era mais eficaz e gastava menos energia que a aplicação de ultravioleta por 30 segundos. Além 
disso, os autores também verificaram uma diminuição na reativação dos coliformes quando da aplicação do ultra-som e ultravioleta.

Hannelore et al. (1999) estudaram a influência do ultra-som na filtração de uma mistura de lodos primário e secundário e conseguiram um incremento de $18 \%$ teor de matéria seca. A qualidade do filtrado permaneceu constante. Os autores concluíram também o ultra-som inibia o "bulking" por meio da quebra de bactérias filamentosas.

Bien \& Wolny (1997), estudando o desaguamento de lodo em um filtro a vácuo com auxílio de um campo ultra-sônico, conseguiu uma redução de 50\% no volume do lodo.

Em estudos realizados por Tiehm et al. (1997), operando digestores com tempos de retenção celular diferentes $(22,16,12$ e 8 dias) alimentados com lodo lisado com ultrasom, observaram que a produção de gás chegou a ser 2,2 vezes maior que o reator controle.

Shimizu et al (1993), estudando um digestor anaeróbio alimentado com lodo proveniente de reator de lodos ativados, lisado com ultra-som, obtiveram uma eficiência de digestão aumentada em $60 \%$, e em $40 \%$ na produção de gás metano.

Chiu et al. (1997), estudaram a eficiência da aplicação de digestão química com e sem aplicação posterior de ultra-som no lodo em excesso a ser levado para a digestão anaeróbia. Os autores concluíram que a aplicação da digestão química, juntamente com aplicação do ultra-som, melhorou a eficiência da digestão anaeróbia, além de promover um aumento na relação ácidos graxos totais em relação a DQO total de $10 \%$ para $66 \%$, vislumbrando a possibilidade de recuperação desses ácidos. 
Muller et al. (2000), utilizando ultra-som em baixa intensidade, somente para quebra de bactérias filamentosas (predominantemente Microthrix Parvicella), tratando lodos de duas plantas diferentes, conseguiram uma redução no volume de lodo flotado de $7 \%$ para $1 \%$ do lodo total.

Lehne e Muller (1999) citam que o uso de ultra-som pode ser mais vantajoso do que outros métodos de desintegração pois são aparelhos pequenos se comparado aos outros e são de fácil instalação em plantas ou tubulações já existentes, além de o risco de obstrução da linha ser menor. O ultra-som ainda tem a vantagem de desintegrar lodos com maiores concentrações de sólidos em relação aos outros tipos de destruição mecânica. Com isso, a energia gasta no ultra-som pode ser compensada com a maior quantidade de sólidos a serem desintegrados. Os autores citam também que o desenvolvimento de novos aparelhos está tornando a prática de aplicação de ultra-som mais vantajosa também economicamente. Já Portenlänger (1999) comenta que o ultra-som também tem a vantagem de ser utilizado a pressão atmosférica e temperatura ambiente, ao contrário de outros métodos de desintegração.

Para introduzir a energia do ultra-som, é necessário a utilização de um transdutor ultra-sônico e uma fonte de potência ultra-sônica ou gerador.

\section{- $\quad$ Transdutor}

Os transdutores são dispositivos destinados a converter um tipo de sinal em outro, com o objetivo de transformar um tipo de energia em outro. Alguns transdutores receberam nomes específicos que os determinam, por exemplo: a lâmpada (converte 
energia elétrica em energia luminosa), o alto falante (energia elétrica em sonora) e o motor elétrico (energia elétrica em mecânica).

Existem basicamente dois tipos de transdutores (Thorton, 2002): o magnetostritivo e o piezoelétrico. O transdutor magnetostritivo é um tipo mais antigo.Uma bobina gera um campo magnético que excita o magneto, criando uma oscilação, que gera o sinal ultra-sônico. O outro tipo de transdutor é o piezoelétrico, neste utiliza-se um cristal que possui como característica, gerar uma diferença de potencial (voltagem) quando é submetido a uma força (de tração ou compressão) em sua superfície.

Na prática, utiliza-se o efeito contrário, ou seja, os cristais são submetidos a uma voltagem de freqüência alta que é aplicada em sua superfície. O cristal, então, gera um movimento mæcânico, que causa o deslocamento do sonotrodo (ponteira) onde ele é fixado, transmitindo a energia ultra-sônica para o interior da cuba, onde é gerada a cavitação.

Como vantagens na utilização dos transdutores piezoeléctricos, estão a melhor transferência de energia, uma maior estabilidade na freqüência e um tamanho menor. Atualmente, a grande maioria dos equipamentos de limpeza ultra-sônicos utiliza o transdutor piezoeléctrico, pois os cristais atuais utilizam uma tecnologia muito avançada e novos materiais que os tornam muito eficientes e confiáveis. 


\section{- Gerador}

O gerador ultra-sônico é a parte do equipamento que ligada à energia elétrica é responsável por converter esta energia (110 ou 220V) com frequiência de 50hz ou $60 \mathrm{hz}$ no sinal de alta freqüência que é aplicado ao transdutor.

\subsubsection{Características do lodo desintegrado}

O lodo é uma complicada mistura de sólidos orgânicos, bactérias, vírus, fungos, protozoários e outros microrganismos que existem tanto na forma unicelular ou em flocos(Erdincler \& Vesilind, 2000). A desintegração deste lodo leva ao rompimento da parede celular dos microrganismos presentes no lodo, e a esse lodo desintegrado dá-se o nome de "lodo lisado".

O lodo lisado contém enzimas, partes de enzimas, cofatores que aceleram as reações de degradação. Segundo Dohanyos et al. (1997b), o lisado serve como fonte de material para muitos grupos celulares pois os sistemas enzimáticos contidos no lisado, ou partes deles, são os mesmos ou similares para diferentes grupos de bactérias. Ainda segundo os autores, a forma mais eficiente de lodo lisado é aquela que é originada das bactérias que estão ativas no processo de degradação, aqui chamado lisado primário. Um tipo de lodo lisado primário é o lodo lisado proveniente de um decantador secundário que é retornado ao tanque de aeração. Um exemplo de lisado secundário é o mesmo lodo citado acima e encaminhado para um digestor anaeróbio. 
Para ilustração do conteúdo de uma célula, Bailey \& Ollis (1986) fornecem uma tabela da composição elementar da Escherichia coli. A tabela 3.6 dá uma idéia do material contido em uma célula e que vai ser liberado após a desintegração.

Tabela 3.6 - Composição química da Escherichia coli

\begin{tabular}{cccc}
\hline Elemento & Porcentagem (peso seco) & Elemento & Porcentagem (peso seco) \\
\hline Carbono & 50 & Sódio & 1 \\
\hline Oxigênio & 20 & Cálcio & 0.5 \\
\hline Nitrogênio & 14 & Magnésio & 0.5 \\
\hline Hidrogênio & 8 & Cloro & 0.5 \\
\hline Fósforo & 3 & Ferro & 0.2 \\
\hline Enxofre & 1 & Outros & $\sim 0.3$ \\
\hline Potássio & 1 & & \\
\hline
\end{tabular}

O conteúdo do lodo lisado vai depender do processo de degradação. Segundo Muller (2001) o lodo lisado pode apresentar um aumento na fração dificilmente biodegradável da DQO, dependendo do processo utilizado para degradação. CHU et. al. (2002) citam que a desintegração pode transformar grandes quantidades de formas insolúveis em formas solúveis. Além disso, para o caso do ultra-som, podem ocorrer algumas das reações: Oxidação de substâncias orgânicas dissolvidas, e reações pirolíticas envolvendo substâncias voláteis.

No caso de aplicação do ultra-som, pode ocorrer formação de $\mathrm{NO}_{\mathrm{x}}$ devido as moléculas de $\mathrm{N}_{2}$ e $\mathrm{O}_{2}$ presentes no meio. Apesar disso, em experiências relatadas por Neis \& Tiehm (1999), não foi encontrada a presença de $\mathrm{NO}_{\mathrm{x}}$, até porque os autores utilizaram ultra-som em amostras de lodo anaeróbio. Além dos $\mathrm{NO}_{\mathrm{x}}$, podem ser encontrados peróxidos no material lisado. Entretanto a formação de peróxidos está intimamente ligada a uma solução saturada de oxigênio no meio (Pétrier et. al., (1999). 
Uma das preocupações quanto ao retorno do lodo lisado ao tratamento biológico é o aumento das concentrações de nitrogênio e fósforo que são liberados na fase líquida. A eficiência técnica e econômica da reciclagem desses produtos vai depender da concentração dos mesmos na fase líquida. Por outro lado, a reciclagem de nutrientes pode melhorar as relações $\mathrm{C}: \mathrm{N}: \mathrm{P}$ em esgotos com baixa concentração de nutrientes. 


\section{Materiais e Métodos}

Visando verificar a influência da lise celular induzida em sistemas aeróbios, foi montado nas dependências do Laboratório de Processos Biológicos da Escola de Engenharia de São Carlos - Universidade de São Paulo - um sistema de tratamento aeróbio do tipo reator seqüencial em batelada (RSB). Aqui são mostrados alguns detalhes do sistema, do modo de operação dos reatores, do aparelho de ultra-som, da coleta das amostras e análise dos parâmetros.

\subsection{Sistema}

Foram utilizados dois reatores (A e B) com as mesmas dimensões. Cada reator tinha seção circular em acrílico transparente, permitindo uma visualização de seu interior, diâmetro de $14,5 \mathrm{~cm}$ e $100 \mathrm{~cm}$ de altura, resultando em um volume total de 16,5 litros, sendo o volume utilizado de 15 litros e o volume de tratamento de 9,5 litros. A aeração era feita mediante bombas de aquário e pedras porosas colocadas no fundo do reator.

Ao longo de sua altura, havia 5 pontos, espaçados a cada $15 \mathrm{~cm}$, para coleta de amostras, entrada de esgoto bruto e saída de esgoto tratado, como mostrado 
esquematicamente na Figura 4.1. O substrato entrava pelo ponto 2 e o efluente saía pelo ponto 3. As tomadas de amostra eram realizadas no ponto 4, assim como a retirada do volume necessário para manutenção da idade do lodo. A altura do lodo , quando sedimentado, não chegou a ultrapassar o ponto 2 .

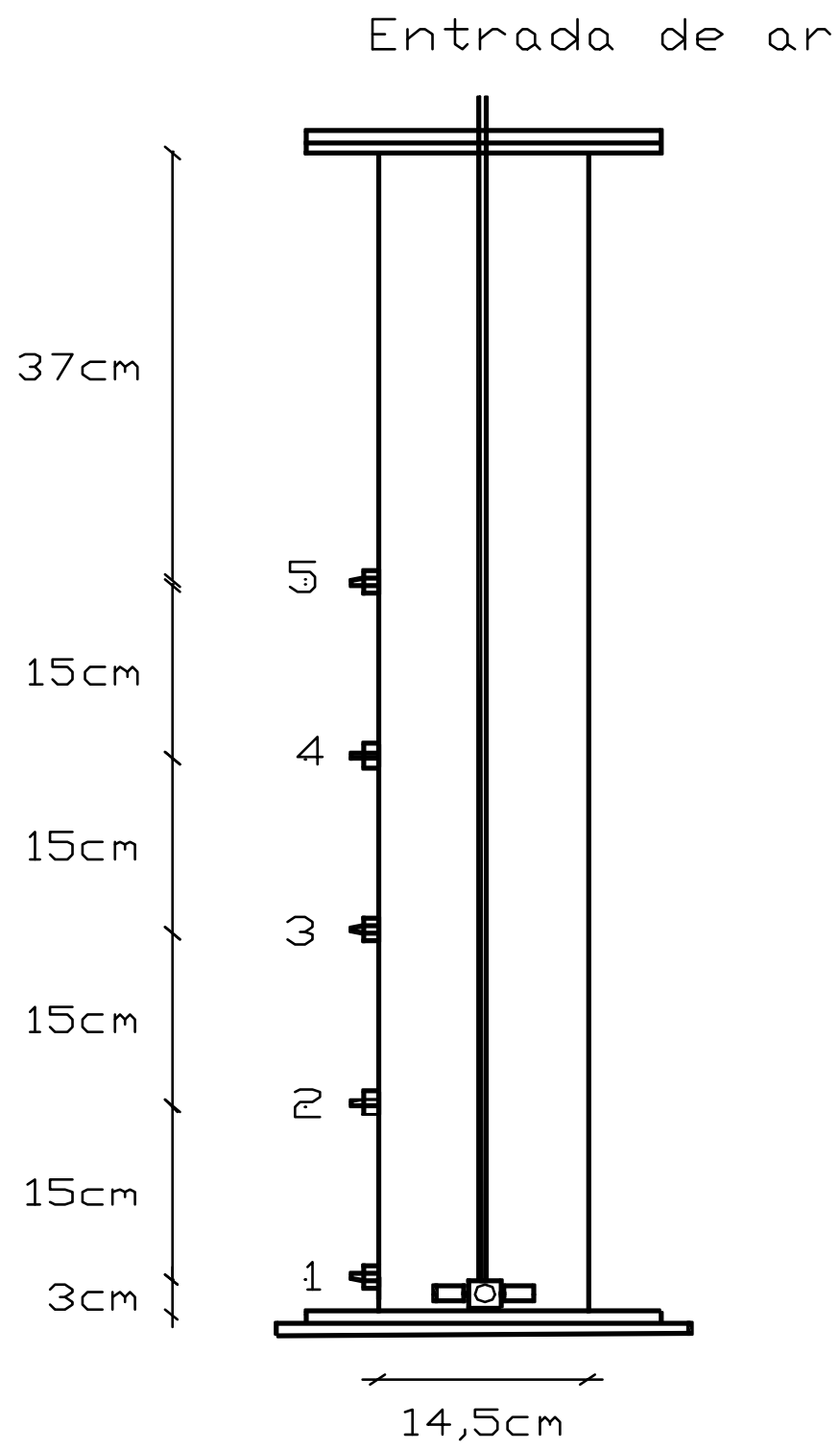

Figura 4. 1- Esquema do reator seqüencial em batelada. 
Foram colocadas duas bombas de aquário para prover ar apara cada um dos dois reatores. As pedras porosas eram limpas periodicamente para evitar entupimentos. As paredes dos reatores, assim como as mangueiras, também eram limpas periodicamente, cada vez que se notava um processo de incrustação acentuado.

$\mathrm{O}$ reator estava contido em uma câmara climatizada a $30 \pm 2^{\circ} \mathrm{C}$ (figura 4.2). O controle operacional do sistema, no que se refere ao acionamento das válvulas solenóides para entrada do substrato e descarte do sobrenadante de cada reator, assim como o controle das fases de operação do reator (enchimento, aeração/reação, repouso e descarte), foi executado por micro-computador.

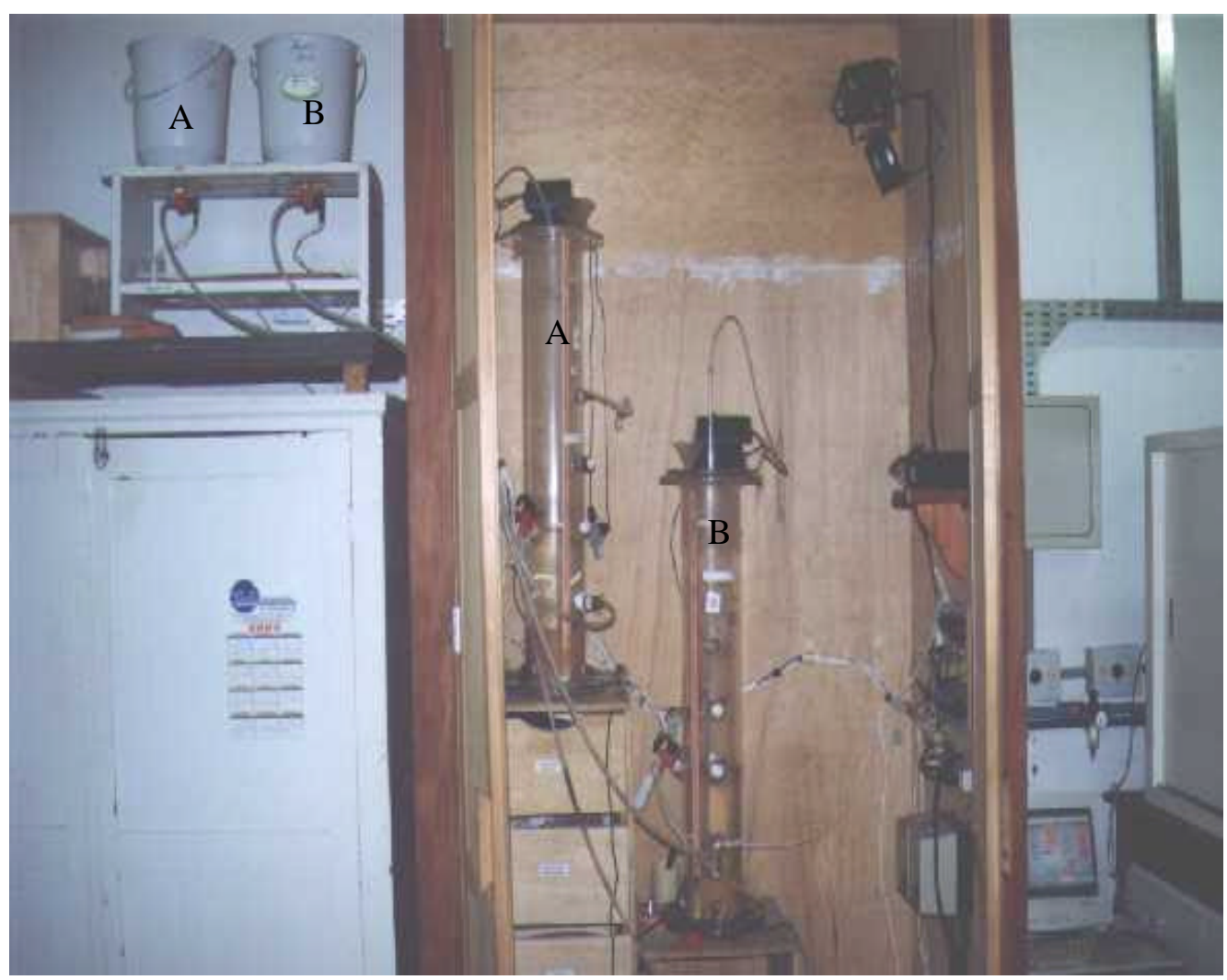

Figura 4. 2- Sistema utilizado na etapa de experimento 
Foi utilizado um microcomputador, modelo PC, com placa de aquisição de dados para controlar uma placa de interface entre o computador e válvulas solenóides, e desenvolveu-se um software em linguagem "visual basic" versão 5.1 2000, em ambiente Windows, através do qual qualquer combinação de períodos de tempo de enchimento, reação, decantação e descarte podiam ser facilmente programados.

Foi instalada no microcomputador uma placa de aquisição de dados 12 bits para barramento ISA, modelo AQB10/12, com as seguintes características (CALLADO, 2001):

- 16 entradas analógicas multiplexadas e não diferenciais (single-ended) com resolução de 12 bits, tempo de conversão de $10 \mu$ s e fundos de $-1 \mathrm{~V}$ a $+1 \mathrm{~V}$, $-5 \mathrm{~V} \mathrm{a}+5 \mathrm{~V} \mathrm{e}-10 \mathrm{~V} \mathrm{a}+10 \mathrm{~V}$, selecionáveis por jumpers;

- 2 saídas analógicas com resolução de 12 bits e fundos de escala de $-10 \mathrm{~V}$ a $+10 \mathrm{~V}$

- 3 contadores independentes de 16 bits com bases de tempo internas de 8 MHz, 4 MHz, 2 MHz, 1 MHz e 500 KHz, selecionáveis por jumpers;

- 3 portas de 8 bits de entrada ou saída digitais com modo de configuração por software;

- 16 endereços I/O selecionáveis por jumpers.

Para armazenamento do afluente, foram colocados dois tanques (A e B) em altura maior que os tanques de aeração para permitir a alimentação por gravidade. Não houve utilização de bombas para entrada de alimentação e para a saída do 
sobrenadante. A operação era realizada por meio da abertura das válvulas solenóides e o fluxo era feito por gravidade. Para coleta do efluente dos tanques de aeração, foram colocados também dois tanques distintos para posterior coleta de amostra e descarte do liquido restante. Somente a operação de retirada de um volume fixo de cada reator para manutenção da idade do lodo era realizada manualmente.

\subsection{Substrato}

Como fonte de alimentação para os microrganismos utilizava-se um substrato sintético simulando o esgoto sanitário desenvolvido por Torres (1992).

A Tabela 4.1 apresenta a composição básica do esgoto sintético utilizado, que foi desenvolvida nos laboratórios do Departamento de Hidráulica e Saneamento especialmente para permitir experimentos com maior grau de reprodutibilidade.

Os compostos principais eram pesados para se fazer um esgoto sintético com um volume de 20 litros, o que daria uma DQO de, aproximadamente, 500-550 mg/l. Como o volume útil de cada reator era de 9,5 litros, então a massa total pesada era diluída em 19 litros, o que gerava uma DQO de, aproximadamente, 520-570mg/l. Juntamente com os compostos principais, para se preparar o esgoto sintético, era necessária a adição de sais minerais (compostos secundários). A adição era da ordem de $5 \mathrm{ml}$ de solução-mãe de sais por 1tro de substrato preparado. Como a base era de 20 litros, então eram adicionados $100 \mathrm{ml}$ de solução de sais para elaboração do substrato sintético. Após o preparo do substrato, o mesmo era divido em partes iguais para alimentação dos reatores A e B. 
Tabela 4. 1- Composição básica do esgoto sintético utilizado (Torres, 1992 - modificado)

\begin{tabular}{|c|c|}
\hline \multicolumn{2}{|c|}{ Compostos principais } \\
\hline Fração orgânica & Compostos correspondentes $(\mathrm{g} / \mathrm{l})$ \\
\hline proteínas & extrato de carne $(0,208)$ \\
\hline carboidratos & $\begin{array}{r}\text { sacarose } 20 \%(0,036) \\
\text { amido comercial } 60 \%(0,113) \\
\text { celulose em pó } 20 \%(0,041)\end{array}$ \\
\hline lipídios & óleo de soja $(0,055)$ \\
\hline \multicolumn{2}{|c|}{ Compostos secundários } \\
\hline Sais Minerais & Concentração na solução-mãe (g/l) \\
\hline $\mathrm{NaCl}$ & 50,0 \\
\hline $\mathrm{MgCl}_{2} \cdot 6 \mathrm{H}_{2} \mathrm{O}$ & 2,0 \\
\hline $\mathrm{CaCl}_{2} \cdot 2 \mathrm{H}_{2} \mathrm{O}$ & 1,6 \\
\hline $\mathrm{NaH}_{2} \mathrm{PO}_{4}$ & 10,5 \\
\hline
\end{tabular}

\subsection{Operação}

A operação foi dividida em duas etapas. Primeiramente foi realizado um monitoramento de controle (etapa controle) nos dois reatores para que se pudessem avaliar as diferenças de comportamento antes e depois da aplicação da lise celular induzida e retorno total do lodo em excesso. Após a etapa de monitoramento do controle, foi realizado o monitoramento da etapa aqui denominada etapa teste. Foi nesta etapa que ocorreu a aplicação da lise celular induzida, por meio de ultra-som. $\mathrm{O}$ lodo sedimentado era coletado por meio de uma mangueira adaptada ao fundo do cone Imhoff e era armazenado para posterior aplicação do ultra-som.

Foram operados dois reatores em batelada (A e B) com ciclos de 12 horas cada. Os reatores operaram com idades do lodo de 12 e 8 dias respectivamente. A idade do lodo foi controlada pela retirada do volume correspondente a manutenção da idade do lodo em cada reator. A retirada era feita duas vezes ao dia no início de cada ciclo operacional. Adotou-se para retirada o instante correspondente a 
aproximadamente uma hora após o inicio do ciclo. Os ciclos tinham a seguinte duração:

Enchimento sem aeração: 1 minuto;

Enchimento com aeração: 49 minutos;

Reação: 10 horas e 59 minutos;

Sedimentação: 30 minutos;

Descarte: 30 minutos.

O volume retirado era colocado em um cone Imhoff adaptado onde permanecia sedimentando por 30 minutos que é o tempo de sedimentação em cada ciclo dos reatores (figura 4.3).

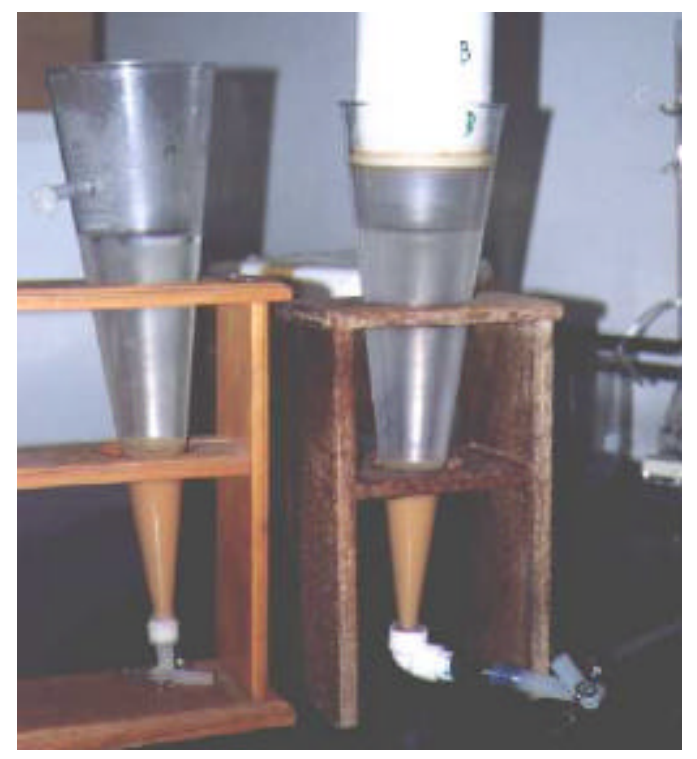

Figura 4. 3 - Cones utilizados para sedimentação do lodo e análise de IVL

Após esse tempo, o lodo era descartado (durante a etapa controle) ou levado para a aplicação do ultra-som onde se realizava a lise celular induzida (durante a 
etapa teste) e posteriormente era adicionado ao tanque de alimentação para reutilização.

Como os dois reatores tinham o mesmo tempo de ciclo (12 horas) então era necessária a aplicação de ultra-som em quatro amostras diariamente (duas amostras para cada reator por dia). As amostras que iam para aplicação do ultra-som eram as amostras coletadas na noite anterior e na manhã do dia da aplicação. A aplicação geralmente era realizada durante o período da tarde.

Os ciclos se iniciavam todos os dias por volta das 8 da manhã e 8 da noite. O substrato era preparado todos os dias imediatamente antes de cada ciclo (com exceção da solução-mãe de sais que era preparada para durar 10 ciclos).

A coleta das amostras, para futuras análises, eram sempre iniciadas no início de cada ciclo (coleta de amostra do afluente e do tanque de aeração) e fim do ciclo anterior (coleta do efluente). A coleta da amostra do tanque de aeração era realizada após o descarte do volume necessário para a manutenção da idade do lodo.

As análises, sempre que possível, eram efetuadas imediatamente após a coleta da amostra. Durante a etapa controle, as análises eram realizadas para amostras do afluente, do efluente e do tanque de aeração. Já na etapa teste, as análises de sólidos e DQO eram realizadas no afluente sem o retorno do lodo desintegrado e com retorno do lodo desintegrado. Isso permitia quantificar o incremento de sólidos e DQO na recirculação do lodo desintegrado. 


\subsection{Ultra-som}

Para a lise celular induzida foi utilizado um aparelho de ultra-som da marca Thorton com frequiência de $20 \mathrm{khz}$ e potência até 100 watts. O sistema apresenta um gerador com timer com contagem até 5 minutos, em intervalos de 5 segundos. Apresenta também um gabinete acústico em chapa com pintura em epóxi e duas ponteiras: macro e microponta em titânio (Tabela 4.2). A micro ponta é utilizada para volumes até $20 \mathrm{ml}$, enquanto que a macroponta é utilizada para volumes até $200 \mathrm{ml}$.

Tabela 4. 2 - Especificações técnicas do aparelho de ultra-som

\begin{tabular}{lc}
\hline Tensão de trabalho: & 110 ou $220 \mathrm{~V} \mathrm{50/60 \textrm {Hz }}$ \\
\hline Consumo: & $150 \mathrm{VA}$ \\
\hline Freqüência: & $20 \mathrm{kHz}$ \\
\hline Potência Ultra-Sônica: & $100 \mathrm{Watts}$ \\
\hline Capacidade baixa: & $20 \mathrm{ml}$ \\
\hline Capacidade alta: & $200 \mathrm{ml}$ \\
\hline Sonotrodo Disponível: & Macroponta e Microponta \\
\hline Fonte: Sítio do equipamento (www.unique.ind.br)
\end{tabular}

As amostras colocadas no aparelho ficavam circundadas por um banho de gelo para evitar aquecimento excessivo da amostra, podendo ocorrer uma desnaturação das proteínas contidas no lodo. O resfriamento servia também para evitar o superaquecimento do transdutor (Figura 4.4).

Como o aparelho apresentava um aquecimento excessivo, mesmo com a utilização do banho de gelo, se fazia necessário, durante o tempo de aplicação do ultra-som, o desligamento do aparelho para permitir o seu resfriamento. $\mathrm{O}$ resfriamento era auxiliado por meio de um ventilador colocado na entrada do gabinete. Com isso, a desintegração de uma amostra de lodo, com um tempo de 
exposição ao ultra-som de 20 minutos, levava mais de 30 minutos para sua total utilização já que tinha o tempo de resfriamento.

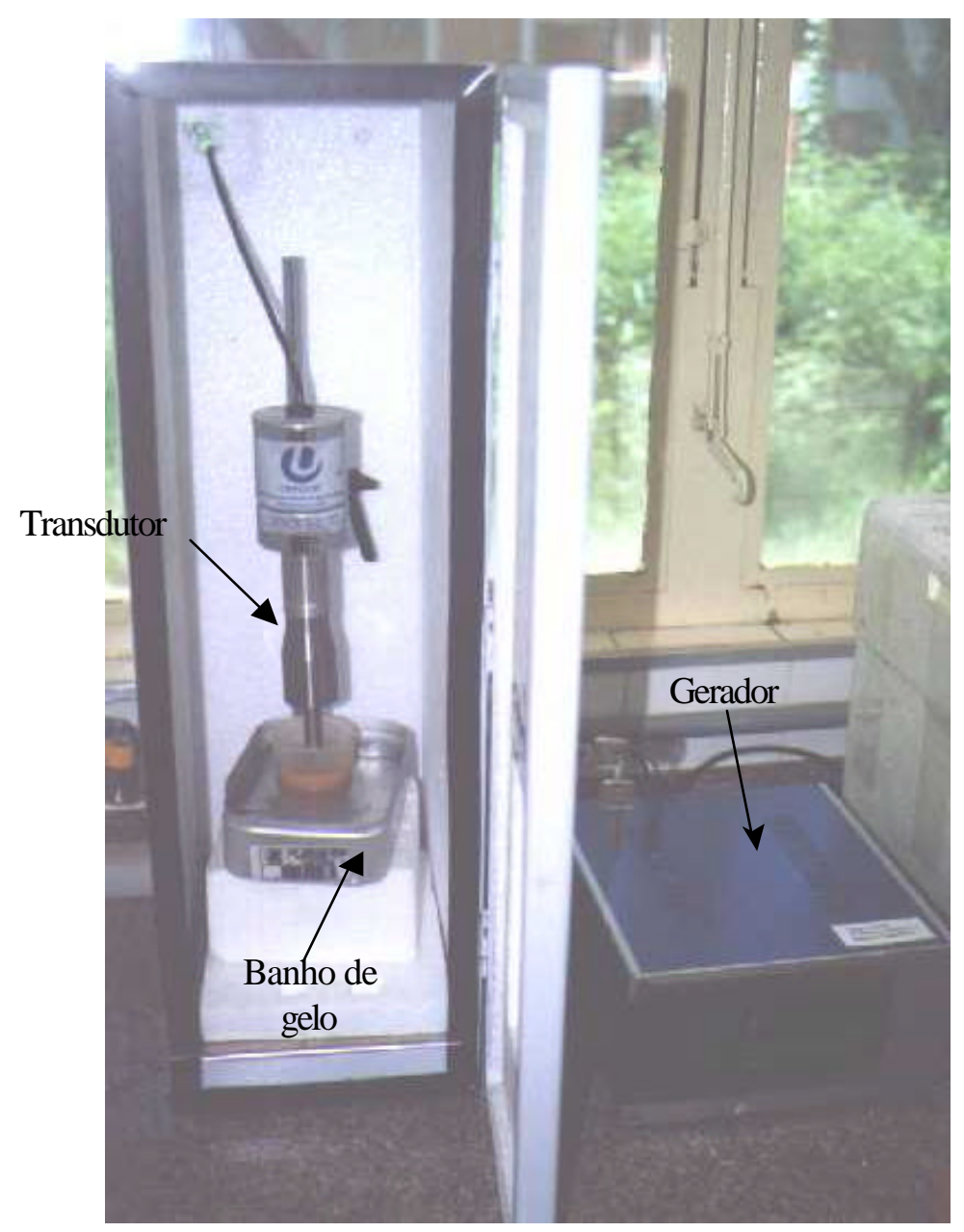

Figura 4. 4 - Equipamento de ultrasom utilizado no estudo

\subsubsection{Grau de desintegração}

Primeiramente foram feitos testes de desintegração do lodo em função da potência aplicada e tempo de exposição. A desintegração foi medida em termos de DQO seguindo orientações do Standard Methods (APHA,1998). Foram realizados 
testes de desintegração do lodo em função da potência aplicada e tempo de exposição.

A fórmula para o cálculo da desintegração do lodo ainda não apresenta consenso entre os pesquisadores quanto à análise da amostra ou quanto à fórmula de cálculo.

Segundo Dohanyos et al. (2000), a quantidade de material lisado que vai para o meio líquido é difícil de determinar. A comparação da DQO total e solúvel, sólidos suspensos totais e voláteis é uma base para avaliação da desintegração. A degradação está intimamente ligada a:

- $\quad$ Aumento da DQO solúvel em relação a DQO total;

- $\quad$ Aumento dos sólidos solúveis voláteis em relação aos sólidos totais voláteis;

- $\quad$ Aumento dos ácidos graxos de cadeia curta na fase líquida do lodo tratado;

- Aumento da produção de gás metano por unidade de DQO total, ou sólidos voláteis do lodo tratado.

Mesmo entre os pesquisadores alemães, que têm vários artigos publicados na área de desintegração do lodo visando o seu reaproveitamento, não se tem uma fórmula consensual para o cálculo da desintegração.

Baier \& Schmidheiny (1997) sugerem o cálculo de um fator de desintegração que pode ser medido tanto pela DQO solúvel quanto pela DQO filtrada:

$$
F_{s o l, f i l}=\frac{D Q O_{s o l, f i l}^{d e s}}{D Q O_{\text {sol }, f i l}^{\text {orig }}}
$$


em que: $F_{\text {sol }, \text { fil }}=$ Fator de Solubilização (DQO solúvel ou filtrada);

$D Q O_{\text {sol, fil }}^{\text {des }}$ DQO da amostra desintegrada (solúvel ou filtrada);

$D Q O_{\text {sol, filt }}^{\text {orig }}=\mathrm{DQO}$ da amostra original (solúvel ou filtrada).

Já Kunz \& Wagner apud Schmitz et al. ${ }^{1}$ (2000) propõem o seguinte método de cálculo, baseado na desintegração química por Hidróxido de Sódio $(\mathrm{NaOH})$ :

$$
D D=\frac{D Q O_{1}-D Q O_{2}}{D Q O_{4}-D Q O_{5}} * \frac{D Q O_{3}}{D Q O_{6}} * 100(\%)
$$

Em que: DD = Grau de desintegração, em termos de DQO;

$\mathrm{DQO}_{1}=\mathrm{DQO}$ do centrifugado da amostra desintegrada;

$\mathrm{DQO}_{2}=\mathrm{DQO}$ do centrifugado da amostra original;

$\mathrm{DQO}_{3}=\mathrm{DQO}$ da amostra imediatamente após a adição de $\mathrm{NaOH}$ 1M;

$\mathrm{DQO}_{4}=$ DQO da amostra centrifugada após $22 \mathrm{~h}$ depois da adição de

$\mathrm{NaOH}$;

$\mathrm{DQO}_{5}=\mathrm{DQO}$ da amostra centrifugada imediatamente após adição de

$\mathrm{NaOH}$;

$\mathrm{DQO}_{6}=\mathrm{DQO}$ após homogeneização da amostra original.

1 KUNZ, P.; WAGNER, St. (1994). Results and Outlooks of Investigation of Sewage Sludge Disintegration - Ergebnisse und Perspektiven aus Untersuchungenzur Klarschlammdesintegration-, awt-abwassertechnik, Heft 1 . 
$\mathrm{O}$ termo $\mathrm{DQO}_{1}-\mathrm{DQO}_{2}$ representa a liberação de $\mathrm{DQO}$ por meio da desintegração; o termo $\mathrm{DQO}_{4}-\mathrm{DQO}_{5}$ representa a liberação de DQO por meio da desintegração química. Admite-se aqui que a desintegração química resulta em uma completa destruição das células. $\mathrm{DQO}_{3}$ e $\mathrm{DQO}_{6}$ é a fração de DQO da amostra depois e antes de adicionar $\mathrm{NaOH} 1 \mathrm{M}$ na razão de 1:3,5 a $20^{\circ} \mathrm{C}$.

Já pesquisadores como Muller et al. (1998) e Nickel (1999), propõem um arranjo simplificado da equação (4.2) (análises de DQO são com referência a DQO filtrada):

$$
D D_{D Q O}=\frac{D Q O_{T}-D Q O_{O}}{D Q O_{\mathrm{NaOH}}-D Q O_{O}} * 100(\%)
$$

Em que: $\mathrm{DD}_{\mathrm{DQO}}=$ Grau de Desintegração em termos de DQO;

$\mathrm{DQO}_{\mathrm{T}}=\mathrm{DQO}$ da amostra desintegrada;

$\mathrm{DQO}_{\mathrm{O}}=\mathrm{DQO}$ da amostra original;

$\mathrm{DQO}_{\mathrm{NaOH}}=\mathrm{DQO}$ da amostra de referência hidrolisada quimicamente em uma solução $0,5 \mathrm{M}$ de $\mathrm{NaOH}$ a $20^{\circ} \mathrm{C}$ por 22 horas.

Por outro lado, outros pesquisadores optaram por medir o grau de desintegração por meio da inativação biológica, como Sperandio \& Paul. (2000), ou consumo específico de oxigênio, como Lehne et al (1999). A fórmula proposta é a seguinte: 


$$
I B(D D)=\left(1-\frac{O C_{m}}{O C_{U}}\right) * 100
$$

Em que: IB (DD) = Inativação Biológica ou Grau de desintegração;

$$
\begin{aligned}
& \mathrm{OC}_{\mathrm{m}}=\text { Consumo específico de Oxigênio depois da desintegração; } \\
& \mathrm{OC}_{\mathrm{u}}=\text { Consumo específico de Oxigênio antes da desintegração. }
\end{aligned}
$$

Autores, como Springer et al. (1996), utilizam a desintegração química, por tratamento ácido ( $\mathrm{pH}$ 2) ou alcalino ( $\mathrm{pH}$ 11,5) para o cálculo do grau de desintegração e utilizaram a seguinte fórmula (com base na DQO solúvel):

$$
G D=\frac{D Q O_{A}}{D Q O_{T}} * 100
$$

Em que: GD = Grau de Desintegração;

$\mathrm{DQO}_{\mathrm{A}}=\mathrm{DQO}$ da amostra desintegrada;

$\mathrm{DQO}_{\mathrm{T}}=\mathrm{DQO}$ total da amostra por desintegração química

Há também autores, como Erdincler \& Vesilind (2000) que medem o grau de desintegração por meio da análise de proteína da amostra centrifugada, usando albumina bovina como controle:

$$
P C D=\frac{[P]_{A}-[P]_{C}}{[P]_{T}-[P]_{C}}
$$

Em que: PCD = Porcentagem de desintegração;

$[\mathrm{P}]_{\mathrm{A}}=$ Concentração de proteína na amostra desintegrada $(\mathrm{mg} / \mathrm{ml})$;

$[\mathrm{P}]_{\mathrm{C}}=$ Concentração de proteína controle; 
$[\mathrm{P}]_{\mathrm{T}}=$ Concentração de proteína na amostra quando todas as células estão desintegradas.

A fórmula para se calcular o grau de desintegração do lodo neste estudo, em termos de DQO, foi baseada na equação (4.6) levando em consideração que o valor da DQO bruta (equivalente a $[\mathrm{P}]_{\mathrm{T}}$ ) era o máximo que poderia ser alcançado pelo valor da DQO filtrada, em membrana de $1,2 \mu \mathrm{m}$, por meio da desintegração do lodo por ultra-som, e que os valores de DQO bruta não sofreram variação significativa após a aplicação do ultra-som. Esta fórmula também foi proposta por Springer et al. (1996). Supondo ser a DQO bruta $100 \%$ de desintegração, chegou-se a seguinte fórmula:

$$
E=\frac{D Q O_{F F}-D Q O_{F I}}{D Q O_{B I}-D Q O_{F I}} * 100
$$

Em que: $\mathrm{DQO}_{\mathrm{FF}}=\mathrm{DQO}$ filtrada após ultra-som (final);

$\mathrm{DQO}_{\mathrm{FI}}=\mathrm{DQO}$ filtrada antes do ultra-som (inicial);

$\mathrm{DQO}_{\mathrm{BI}}=\mathrm{DQO}$ bruta antes do ultra-som (inicial).

O valor da DQO filtrada inicial também foi levado em conta na fórmula visto que já existe um certo valor de DQO filtrada na amostra (equivalente a $[\mathrm{P}]_{\mathrm{C}}$ ). Caso não fosse colocado o valor da DQO filtrada inicial, a eficiência da desintegração não corresponderia com a realidade. 


\subsection{Análises}

Com o andamento da etapa de controle e descarte diário dos lodos em cada reator, foi observado que o volume de lodo nos cones Imhoff, preenchidos com os respectivos volumes de descarte, se situava em torno de $100 \mathrm{ml}$ por ciclo. Como eram dois ciclos por dia, o volume total de lodo sedimentado se situava em torno de $200 \mathrm{ml}$ para cada reator.

Como o volume diário descartado era de $200 \mathrm{ml}$ e o volume máximo permissível para ser colocado no aparelho de ultra-som também era de 200ml, foram feitos testes para se verificar a influência do volume de lodo a ser desintegrado (100 e $200 \mathrm{ml}$ ) e o tempo de exposição.

Foram efetuadas análises microscópicas do lodo para se poder verificar os microrganismos presentes nos reatores, bem como visualizar o grau de desintegração do lodo após aplicação do ultra-som em diferentes tempos de exposição. Durante a etapa teste, foram realizadas análises mensais de microscopia para acompanhamento dos microrganismos presentes nos reatores e sua correlação com os outros exames. As amostras eram coletadas sempre no início de cada ciclo, imediatamente após o descarte do volume necessário para manutenção da idade do lodo em cada reator.

Para as análises microbiológicas do lodo, foi utilizado o Microscópio Olympus BX60, acoplado à câmera com captura de imagem e software Image-Pro Plus. As análises das morfologias seguiram as orientações fornecidas por Jenkins et al. (1993).

A estimativa do Número Mais Provável (NMP) de bactérias nitrificantes foi realizada segundo método descrito por Schmidt \& Belser (1984), adaptando-o para 
amostras de esgotos sanitários, visto que o método foi desenvolvido para amostras de solo.

O processo de nitrificação, conforme explanado anteriormente, ocorre em duas etapas: a nitritação e a nitratação. Assim, a determinação do NMP das bactérias nitrificantes é realizada também em duas etapas: o NMP das bactérias oxidadoras de amônia e o NMP das bactérias oxidadoras de nitrito.

Devido ao grande tempo dispendido (cerca de 1 mês) para determinação de NMP, essas determinações foram efetuadas apenas uma vez durante cada etapa do estudo, sempre ao seu final.

Foram efetuadas também análises da taxa de consumo de oxigênio (TCO) para poder verificar as variações no consumo de oxigênio nos dois reatores antes e depois da lise celular. Para a análise foi utilizado um aparelho medidor de oxigênio dissolvido consistindo de uma sonda DO-DIN, um coletor de dados do tipo CBL (Computer-Based Laboratory System) e uma calculadora TI-89. Todos os componentes da Texas Instruments.

Para se medir o consumo de oxigênio em reatores contínuos se faz uso de um aparato similar em regime de batelada, assim pode-se medir o consumo de oxigênio naquele instante que vai servir para qualquer outro tempo se as condições de alimentação e oxigenação não variarem no sistema contínuo.

Para os reatores em batelada as concentrações variam com o tempo. Por isso, para uma medição mais fiel da taxa de consumo de oxigênio no reator em batelada, foram realizadas "bateladas" durante todo o tempo de duração do ciclo dos reatores A e B (aproximadamente onze horas). 
Imediatamente após o início de um ciclo, foi retirada uma amostra e introduzida em um erlenmeyer contendo um imã. Esse aparato foi colocado em cima de um agitador magnético que permaneceu ligado durante todo o experimento para evitar zonas mortas (na fase aerada do experimento) e para evitar a sedimentação do lodo (na fase sem aeração). Dentro do erlenmeyer também estava contido a sonda de oxigênio dissolvido e uma pedra porosa ligada a um aerador de aquário, que por sua vez estava ligado ao computador que monitorava os reatores.

Depois de colocada a amostra, foram ligadas a sonda e o aerador. A sonda registrava a quantidade de oxigênio dissolvido a cada 99 segundos. O aerador de aquário foi programado para ligar e desligar em intervalos de tempo préestabelecidos. A cada hora e 30 trinta minutos aproximadamente o aerador era desligado por cerca de 20 minutos e ligado novamente. Com isso tinha-se uma idéia do comportamento da taxa de consumo durante todo o ciclo operacional.

Foram também efetuados balanços de massa nos dois reatores (A e B) para as etapas controle e teste para poder quantificar as formas de DQO e nitrogênio presentes no afluente e efluente dos reatores. A figura 4.5 ilustra o esquema das massa nos reatores.

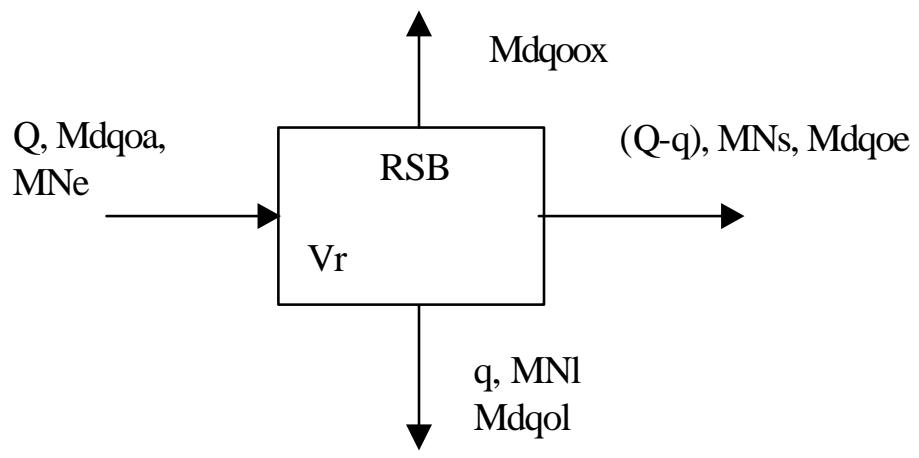

Figura 4. 5 - Balanço de massa dos reatores em batelada 
As variáveis envolvidas no balanço de DQO e nitrogênio estão descritas na tabela 4.3:

Tabela 4. 3 - Variáveis envolvidas nos balanços de massa

\begin{tabular}{|c|c|c|}
\hline Variáveis & & $\begin{array}{c}\text { unidade } \\
\mathrm{maDQO} / \text { ciclo }\end{array}$ \\
\hline DQOe & DQO total afluente & mgDQO/ciclo \\
\hline DQOs & DQO total efluente & $\mathrm{mgDQO} /$ ciclo \\
\hline Q & Vazão afluente & l/ciclo \\
\hline$q$ & Vazão de lodo & l/ciclo \\
\hline Sta & DQO afluente & $\mathrm{mg} / \mathrm{l}$ \\
\hline Ste & DQO efluente & $\mathrm{mg} / \mathrm{l}$ \\
\hline fev & Razão DQO/SSV & $\mathrm{mg} \mathrm{DQO} / \mathrm{mg} \mathrm{SSV}$ \\
\hline Xv & SSV no tanque & mgSSV/l \\
\hline Ot & Taxa de Utilização de oxigênio & $\mathrm{mgO}_{2} \mathrm{l} \cdot \mathrm{h}$ \\
\hline Mon & Massa de Oxigênio para Nitrificação & $\mathrm{mgO}_{2} /$ ciclo \\
\hline $\mathrm{Vr}$ & Volume do reator & I \\
\hline Ntka & Nitrogênio total Kjeldahl afluente & $\mathrm{mgN} / \mathrm{l}$ \\
\hline Ntke & Nitrogênio total Kjeldahl efluente & $\mathrm{mgN} / \mathrm{l}$ \\
\hline Nna & Nitrato no alfuente & \\
\hline Nne & Nitrato no efluente & $\mathrm{mgN} / \mathrm{l}$ \\
\hline fn & fração de Nitrogênio no lodo & $\mathrm{mgN} / \mathrm{l}$ \\
\hline Mdqoe & Massa de DQO no efluente & $\mathrm{mgDQO} /$ ciclo \\
\hline Mdqol & Massa de DQO no lodo & $\mathrm{mgDQO} /$ ciclo \\
\hline Mdqoox & Massa de DQO oxidada & mgDQO/ciclo \\
\hline MNna & Massa de nitrato no afluente & mgN/ciclo \\
\hline MNne & Massa de nitrato efluente & $\mathrm{mgN} /$ ciclo \\
\hline $\begin{array}{l}\text { MNte } \\
\text { MNI }\end{array}$ & $\begin{array}{l}\text { Massa de Nitrogênio total efluente } \\
\text { Massa de Nitrogênio no lodo }\end{array}$ & $\begin{array}{l}\mathrm{mgN} / \text { ciclo } \\
\mathrm{mgN} / \text { ciclo }\end{array}$ \\
\hline \%DQO & Balanço de DQO & $\%$ \\
\hline$\% \mathrm{~N}$ & Balanço de Nitrogênio & $\%$ \\
\hline
\end{tabular}

Segundo Barker \& Dold (1995), para se efetuar um balanço de DQO em um sistema, é necessário estimar a DQO no efluente, no lodo e a quantidade oxidada. A massa de DQO no efluente é dada por:

$$
\text { Mdqoe }=\text { Q.Ste }
$$

Similarmente, conhecendo a concentração de sólidos no lodo em excesso, e conhecendo a razão DQO/SSV (fcv), a massa de DQO no lodo é dada por:

$$
\mathrm{Mdqol}=\mathrm{q} \cdot \mathrm{Xv} \cdot \mathrm{fcv}
$$


Em um sistema aeróbio, a quantidade de DQO oxidada é determinada pela taxa de consumo de oxigênio, após dedução do oxigênio requerido para nitrificação. A massa de oxigênio requerida para a nitrificação é dada por:

$$
\text { Mon }=\text { Q. } . \text { Ntka-Ntke) }
$$

A massa de DQO oxidada por ciclo de operação será dada por:

Mdqoox=Ot.Vr.12-Mon

A massa total de DQO que deixa o reator é dada por:

DQOs=Mdqoe+Mdqol+Mdqoox

A massa de DQO que entra no reator é dada pela seguinte equação:

$$
\text { DQOe }=\text { Q.Sta }
$$

Com isso, a relação de DQO, em termos de porcentagem, é dada por:

$$
\% D Q O=\left(\frac{D Q O s}{D Q O e}\right) 100
$$

Para o balanço de nitrogênio é necessário estimar a massa de nitrato no efluente, a massa de Nitrogênio Total Kjeldahl (NTK) no efluente e a massa de NTK no lodo. A massa de nitrato no efluente é dada por:

$$
\text { MNne=Q.Nne }
$$

Analogamente, a massa de NTK no efluente é dada por:

$$
\text { MNtke=Q.Ntke= }
$$


Para se estimar a massa de nitrogênio no lodo, deve-se assumir uma valor para o valor da fração de nitrogênio no lodo (fn) e seguir a equação (4.16):

$$
\mathrm{MNl}=\mathrm{q} \cdot \mathrm{Xv} \cdot \mathrm{fn}
$$

Para o cálculo da massa de nitrogênio efluente reator, se faz necessário uma soma das equações (4.14), (4.15) e (4.16):

$\mathrm{MNs}=\mathrm{Mne}+\mathrm{Mntke}+\mathrm{MNl}$

Para o cálculo da massa que entra no reator, segue-se a equação (4.18):

$\mathrm{MNe}=\mathrm{Q} \cdot \mathrm{Ntka}+\mathrm{Q} \cdot \mathrm{Nna}$

Assim, para se calcular a relação entrada-saída, usa-se a equação (4.19):

$$
\% N=\left(\frac{M N s}{M N e}\right) \cdot 100
$$

\subsection{Monitoramento}

Visando uma comparação entre os reatores A e B e também entre as etapas de controle e teste, foi feito um monitoramento no sistema de lodos ativados

Foram realizadas amostragens nos pontos afluente, efluente e tanque de aeração de cada reator para monitoramento dos sistemas de tratamento. Foram realizadas análises de DQO bruta e filtrada; sólidos totais, fixos, e voláteis; sólidos suspensos totais, fixos e voláteis; fósforo total; nitrogênio total, amoniacal orgânico; nitrito e nitrato. Além dessas análises, foram também efetuadas medições de IVL. 
As análises efetuadas, bem como suas freqüências, estão relacionadas na Tabela 4.4. Todos as análises foram realizadas de acordo com as metodologias citadas no Standard Methods (APHA, 1998).

Tabela 4. 4 - Parâmetros analisados nas duas etapas do estudo

\begin{tabular}{|c|c|c|}
\hline Parâmetro & Método & Freqüência \\
\hline$\overline{\mathrm{DQO}}$ solúvel $\left(\mathrm{mgO}_{2} / l\right)$ & espectrofotométrico & 2x semana \\
\hline DQO total $\left(\mathrm{mgO}_{2} / l\right)$ & espectrofotométrico & 2x semana \\
\hline N-NTK (mgN/l) & titulométrico & 1x semana \\
\hline $\mathrm{N}-\mathrm{NH}_{4}(\mathrm{mgN} / \mathrm{l})$ & titulométrico & 1x semana \\
\hline $\mathrm{N}-\mathrm{NO}_{2}^{-}(\mathrm{mgN} / \mathrm{l})$ & espectrofotométrico & 1x semana \\
\hline $\mathrm{N}-\mathrm{NO}_{3}{ }^{-}(\mathrm{mgN} / \mathrm{l})$ & espectrofotométrico & 1x semana \\
\hline Fósforo (mgP/l) & espectrofotométrico & 1x semana \\
\hline $\mathrm{SST}(\mathrm{mg} / \mathrm{l})$ & gravimétrico & 2x semana \\
\hline $\mathrm{SSV}(\mathrm{mg} / \mathrm{l})$ & gravimétrico & 2x semana \\
\hline $\mathrm{SSF}(\mathrm{mg} / \mathrm{l})$ & gravimétrico & 2x semana \\
\hline $\mathrm{OD}(\mathrm{mg} / \mathrm{l})$ & potenciométrico & - \\
\hline $\mathrm{pH}$ & potenciométrico & - \\
\hline
\end{tabular}

As análises de nitrogênio e fósforo foram realizadas na forma de perfil semanal durante a etapa teste. Durante a etapa controle, essas análises foram esporádicas visando acompanhar se ocorria nitrificação e remoção de fósforo em cada reator. Somente na etapa teste é que o acompanhamento foi mais freqüente, visto que, na etapa controle, o processo nitrificação e remoção de fósforo em reatores aeróbios em batelada tratando esgoto sintético já foi bastante estudado em pesquisas anteriores no laboratório de Processos Biológicos (Sousa, 1996; Callado, 2001; Oliveira, 2001). 


\section{Resultados e Discussão}

Para poder gerar uma melhor visualização dos resultados obtidos nessa pesquisa, os resultados aqui obtidos foram divididos por análise realizada e subdivididos nas etapas controle e teste para cada um dos reatores. Antes de mostrar os resultados do monitoramento de cada etapa, serão mostrados os testes preliminares com o aparelho de ultra-som.

A etapa denominada controle foi realizada durante o período de 130 dias e tinha por finalidade a verificação do desempenho dos reatores A e B para futura comparação com a etapa posterior (aqui denominada de etapa teste).

Para a etapa de controle foi conseguido um lodo que estava sendo utilizado em outra pesquisa nas dependências do Laboratório de Processos Biológicos da Escola de engenharia de São Carlos. A escolha desse lodo foi devido ao fato que o mesmo já estava adaptado ao substrato sintético e a temperatura de trabalho $(30 \pm$ $2^{\circ}$ ). Com o lodo já escolhido, o mesmo foi colocado nos dois reatores e foram alimentados com o substrato sintético, já descrito anteriormente, por 40 dias (80ciclos) para que a idade do lodo escolhida para cada reator estivesse adaptada (12 dias para o reator A e 8 dias para o reator B). 
A etapa teste teve a duração aproximada de 90 dias e teve como finalidade analisar o comportamento dos reatores A e B quando do retorno de seus lodos de excesso depois de submetidos ao ultra-som (lise celular forçada). Nesta etapa foram feitas as análises já descritas anteriormente, e também foi feito um acompanhamento microbiológico das biomassas dos dois reatores.

\subsection{Testes com o ultra-som}

Para a lise celular forçada foi utilizado o aparelho de ultra-som da Thorton (ver figura 4.4). Primeiramente foram feitos testes de desintegração do lodo em função da potência aplicada e tempo de exposição. A figura 5.1 ilustra o comportamento da DQO filtrada do lodo quando submetido ao aparelho de ultrasom. O lodo utilizado para os experimentos era o do descarte dos reatores A e B durante a etapa controle. A desintegração foi medida em termos de DQO determinada segundo procedimento do Standard Methods (APHA,1998).

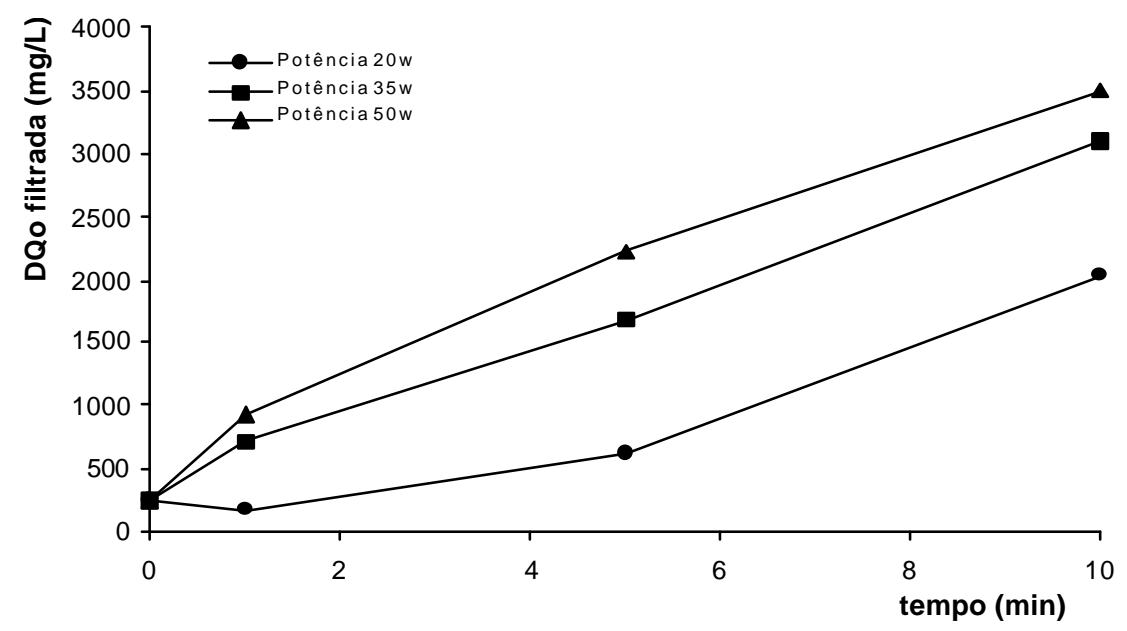

Figura 5. 1- DQO filtrada do lodo submetido a diferentes tempos e frequiências de ultra-som 
Como pôde ser observado, a lise celular induzida provocou um aumento na DQO filtrada, indicando que o lodo está sendo desintegrado e solubilizado. Esse aumento é proporcional ao tempo de exposição e aumento da potência do ultra-som. No caso estudado, a concentração do lodo estava em torno de $14000 \mathrm{mg} / \mathrm{L}$ em termos de sólidos totais. Após esse primeiro teste foi definido que a potência de trabalho seria de 95w, próximo a faixa limite do aparelho que é de $100 \mathrm{w}$.

Com o andamento da etapa de controle e descarte diário dos lodos em cada reator, foi observado que o volume de lodo nos cones Imhoff, preenchidos com os respectivos volumes de descarte, se situava em torno de $100 \mathrm{ml}$ por ciclo. Como eram dois ciclos por dia, o volume total de lodo sedimentado se situava em torno de $200 \mathrm{ml}$ para cada reator.

Como o volume diário descartado era de $200 \mathrm{ml}$ e o volume máximo permissível para ser colocado no aparelho ultra-som que estava sendo utilizado também era de $200 \mathrm{ml}$, foram feitos outros testes para se verificar a influência do volume de lodo a ser lisado e o tempo de exposição.

Primeiramente foram feitos testes com o aparelho de ultra-som para uma amostra contendo $200 \mathrm{ml}$ de lodo sedimentado, o que corresponde ao lodo de dois ciclos de 12 horas. A figura 5.2 ilustra o comportamento da DQO do lodo em função do tempo de exposição da amostra ao aparelho com uma potência de 95w (o que dá uma potência volumétrica de $0,48 \mathrm{w} / \mathrm{ml})$. O objetivo desses testes era avaliar a possibilidade de se realizar somente uma aplicação de ultra-som no lodo diário (dois ciclos) em vez de duas aplicações de ultra-som (uma para cada ciclo)

Como pode ser observado, a DQO bruta não mostra uma variação significativa com o aumento da exposição do lodo ao ultra-som. 


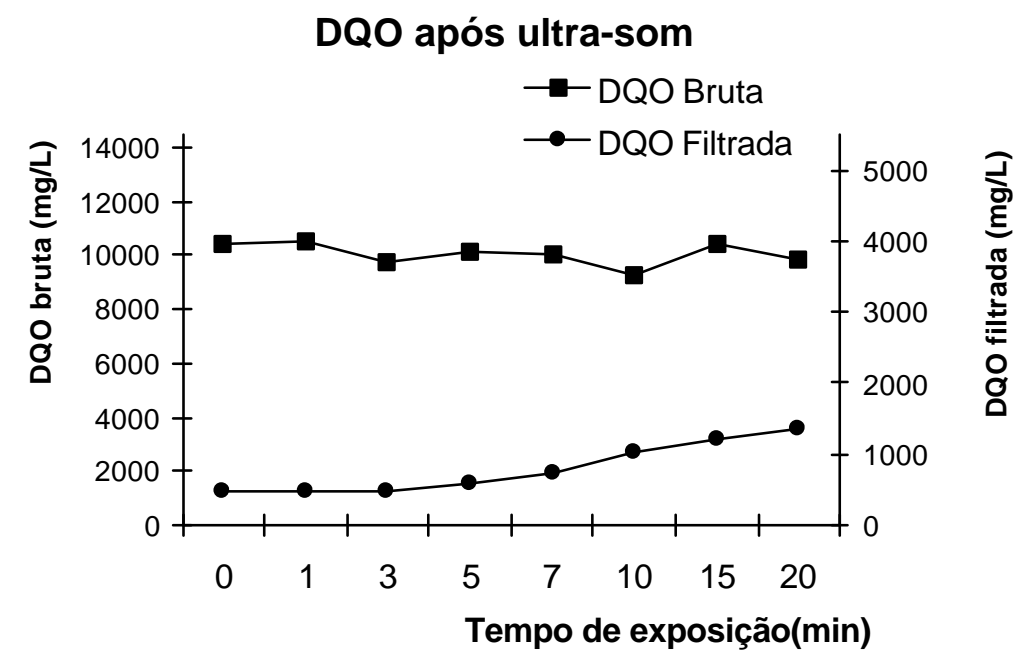

Figura 5. 2 - Variação da DQO após ultra-som para 200ml de amostra

Como pode ser observado, a DQO bruta não mostra uma variação significativa com o aumento da exposição do lodo ao ultra-som, o que foi levado em conta na fórmula para se calcular o grau de desintegração onde se coloca a DQO bruta como o máximo de DQO que a filtrada pode alcançar após a lise celular forçada

A tabela 5.1 fornece a eficiência do ultra-som em relação ao tempo de exposição.

Tabela 5. 1- Tempo de exposição e eficiência do ultra-som para 200ml de amostra

\begin{tabular}{cccc}
\hline Tempo lise $(\mathrm{min})$ & DQO Bruta & DQO Filtrada & \% lise \\
\hline 0 & 10443 & 470 & 0,00 \\
1 & 10510 & 497 & 0,27 \\
3 & 9768 & 497 & 0,29 \\
5 & 10173 & 578 & 1,11 \\
7 & 10038 & 751 & 2,94 \\
10 & 9296 & 1021 & 6,24 \\
15 & 10412 & 1205 & 7,40 \\
20 & 9799 & 1346 & 9.39 \\
\hline DQO máxima & 10510 & & \\
DQO mínima & 9296 & & \\
\hline
\end{tabular}

Obs. - Ver equação 4.7 para o cálculo da \% lise 
Nota-se que o grau de desintegração, calculado de acordo com a equação 4.7, foi da ordem de $9 \%$ para um tempo de exposição de 20 minutos. Como a medida do grau de desintegração é realizada de maneiras diferentes entres os pesquisadores já citados no capítulo Materiais e Métodos, fica difícil fazer uma correlação entre este estudo e o de outros autores.

Foi realizado outro teste com um volume de amostra de $100 \mathrm{ml}$ (potência volumétrica de $0,95 \mathrm{w} / \mathrm{ml})$. A figura 5.3 ilustra as variações ocorridas neste teste.

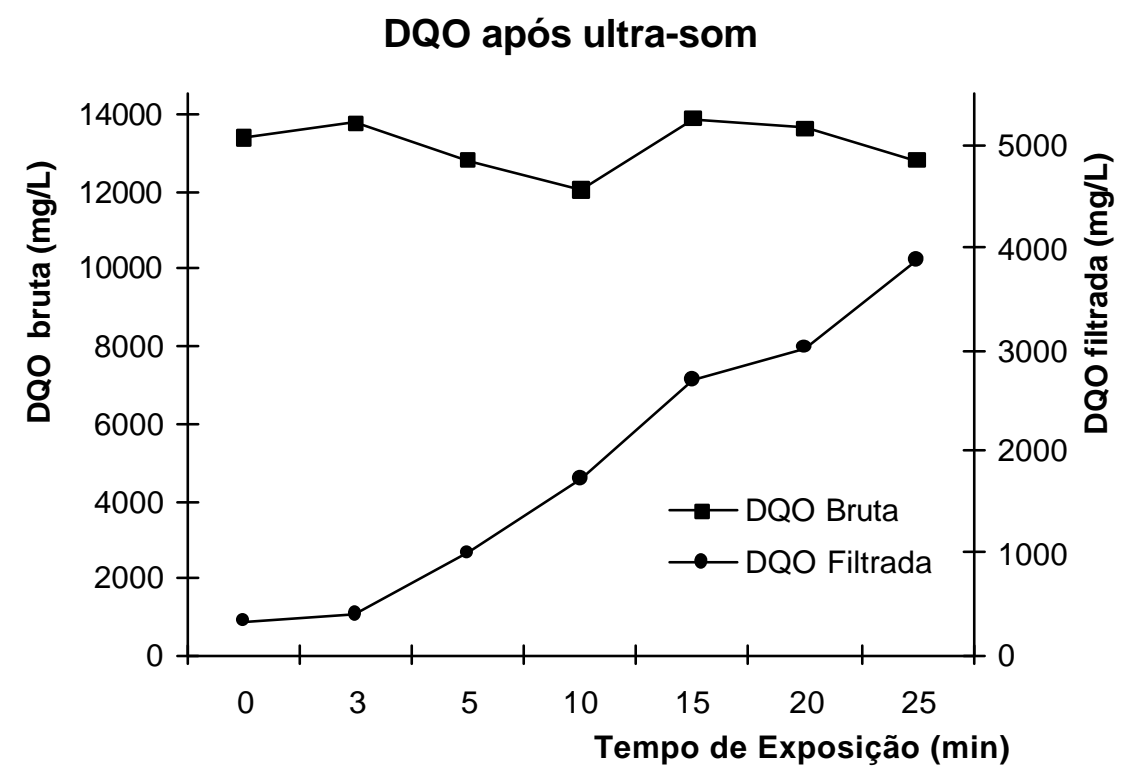

Figura 5. 3- Variação da DQO após ultra-som para 100ml de amostra

Nota-se claramente que a eficiência do ultra-som foi bem mais significativa para a amostra contendo $100 \mathrm{ml}$ de lodo, como observado na tabela 5.2. O valor da DQO filtrada para a amostra de $100 \mathrm{ml}$ alcançou o valor de $3017 \mathrm{mg} / \mathrm{L}$ contra 1346mg/L, para a amostra de 200ml, em um mesmo tempo de exposição. 
Tabela 5. 2- Tempo de exposição e eficiência do ultra-som para 100ml de amostra

\begin{tabular}{cccc}
\hline Tempo lise $(\mathrm{min})$ & DQO Bruta & DQO Filtrada & $\%$ lise \\
\hline 0 & 13343 & 346 & 0,00 \\
3 & 13747 & 400 & 0,40 \\
5 & 12803 & 994 & 5,20 \\
10 & 12061 & 1722 & 11,74 \\
15 & 13882 & 2693 & 17,34 \\
20 & 13613 & 3017 & 20,13 \\
25 & 12803 & 3880 & 28,37 \\
\hline DQO máxima & 13882 & & \\
DQO mínima & 12061 & & \\
\hline
\end{tabular}

Para uma melhor ilustração, foi elaborado um gráfico que correlaciona a DQO filtrada com o tempo de exposição para as duas potências volumétricas aplicadas. A figura 5.4 ilustra este comportamento.

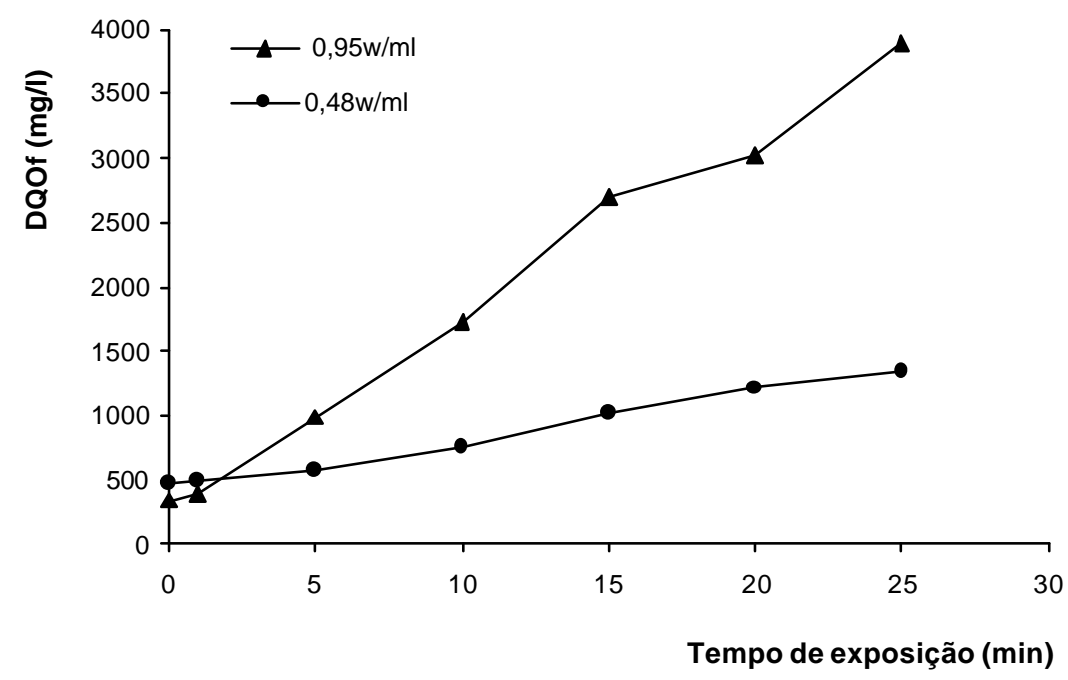

Figura 5. 4- Comportamento da DQO filtrada em condições de potência e tempos diferentes

Nota-se claramente que uma maior potência volumétrica aplicada ao lodo, gera uma maior DQO filtrada em um menor tempo apesar de que, no teste com uma potência volumétrica de $0,95 \mathrm{w} / \mathrm{ml}$, havia uma maior concentração de DQO devido a uma maior concentração de sólidos. De acordo com Portenlänger (1999), a 
concentração de sólidos influi positivamente na eficiência da lise celular forçada, pois favorece o choque entre as partículas mais próximas uma das outras, auxiliando na desintegração celular.

Com isso foi estipulado que a lise forçada seria realizada duas vezes ao dia (uma vez por ciclo) para cada reator, perfazendo o total de quatro aplicações de ultrasom por dia. Além disso, o tempo de exposição ao ultra-som seria de 20 minutos. Caso fosse preciso, esse tempo seria aumentado. Entretanto temia-se por uma falha do aparelho de ultra-som, pois o mesmo quebrou duas vezes durante a etapa de testes preliminares.

Importante lembrar que não foi realizado um estudo para avaliar se a quantidade de aplicações em função do grau de desintegração era mais ou menos viável economicamente. $\mathrm{O}$ objetivo da pesquisa era o de se analisar o comportamento do lodo no retorno ao tanque de aeração após a desintegração com ultra-som.

\subsection{Análise microscópica do lodo submetido ao ultra-som}

Depois de concluir que o tempo de exposição dos lodos de descarte ao ultra-som seria de 20 minutos para cada amostra de $100 \mathrm{ml}$, um outro teste foi feito utilizando análises microscópicas do lodo após a aplicação do ultra-som. As análises foram feitas para cada reator: A e B. A figura 5.5 ilustra o comportamento dos flocos durante o tempo de aplicação do ultra-som para o reator A.

Como pode ser observado, o lodo do reator A apresentava um floco um pouco pequeno e disperso, mas apresentava uma fauna bastante variada, característica de um lodo bem estabilizado. Com a exposição do lodo ao ultra-som, 
pôde-se notar que os flocos começavam a se desintegrar até chegar a uma completa desintegração no tempo de 20 minutos.

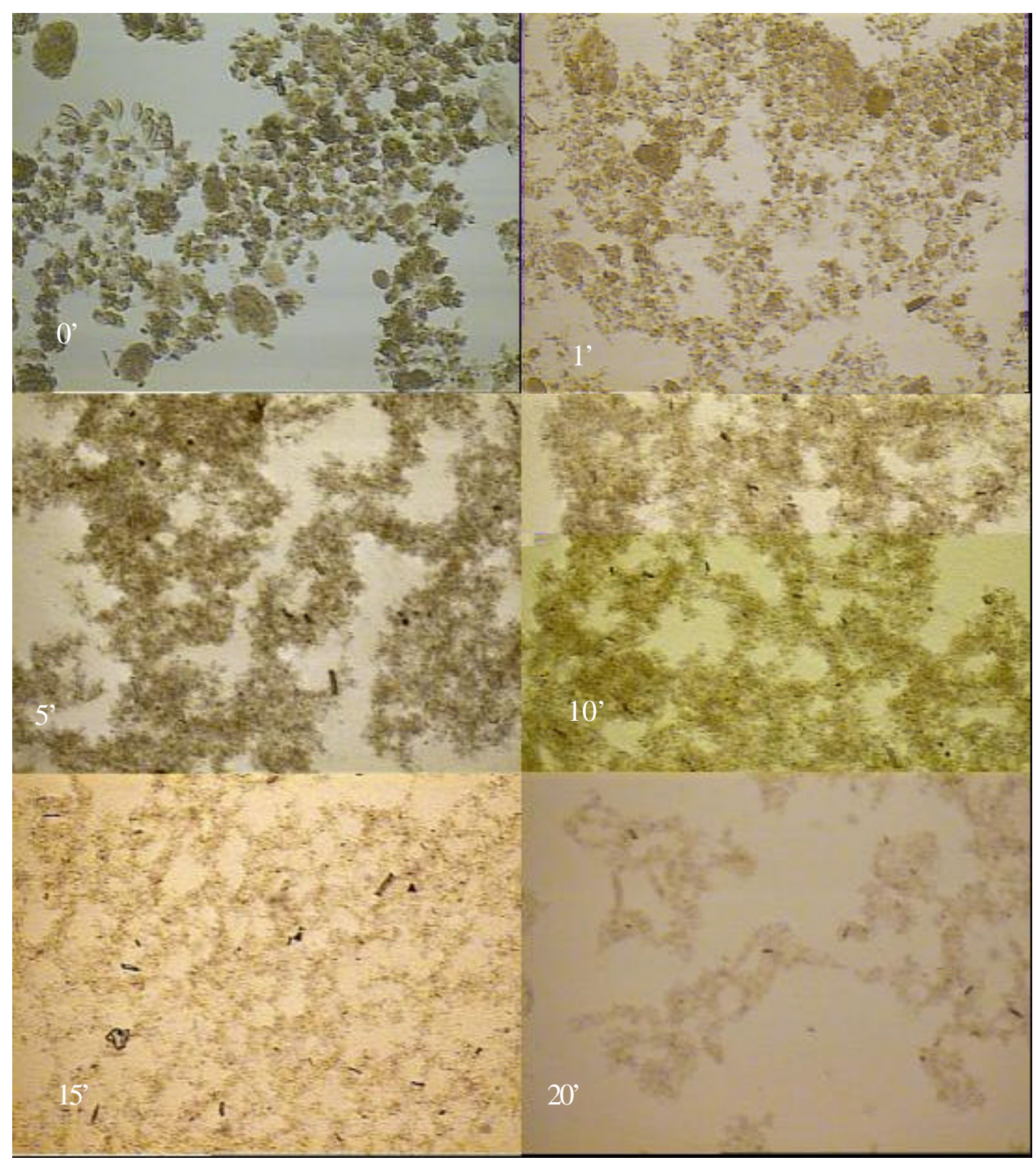

Figura 5. 1- Aspecto do lodo do reator A após exposição ao ultra-som (40x) 
Os exames microscópicos indicaram que, no tempo de 1 minuto, o lodo ainda apresentava um floco bem definido. Após o tempo de 5 minutos de aplicação, os flocos já apresentavam algumas rupturas e podia-se notar um aumento nos sólidos em suspensão. Foram encontrados microrganismos como rotíferos, ciliados fixos e ciliados rastejantes, porém sem movimentação alguma. Com o tempo de exposição de 10 minutos, a única forma conhecida de microrganismos encontrada foi a de rotíferos (sem movimentação alguma), sugerindo que os demais microrganismos já estavam desintegrados. Entretanto o floco ainda apresentava algum tipo de estrutura.

A análise do lodo para o tempo de 15 minutos indicou que os flocos estavam cada vez menos agregados e se misturando com as partículas em suspensão. Com esse tempo de exposição, não foram encontradas morfologias definidas de microrganismos. Para o tempo de 20 minutos pôde-se notar que os flocos estavam totalmente desintegrados e completamente misturados às partículas em suspensão. Já se podia inferir que a biomassa se transformou em matéria orgânica que serviria de alimento aos microrganismos presentes no reator.

O lodo do reator $\mathrm{B}$ apresentou floco bem melhor definido e menos disperso que o lodo do reator A. Foi observada a presença de ciliados fixos, livres e rastejantes, flagelados, rotíferos e uma quantidade expressiva de bactérias filamentosas. Entretanto essas bactérias não causaram nenhum problema de intumescimento do lodo, durante todo o decorrer da pesquisa com os reatores em batelada (figura 5.6).

Com a exposição de 1 minuto, pôde-se notar uma pequena dispersão do lodo. Não se podia afirmar ainda que a dispersão era causada pelo ultra-som ou pela amostragem. Para o tempo de 5 minutos, observou-se claramente que os grandes 
flocos já estavam desaparecendo. Não era mais notada a presença de ciliados fixos e rastejantes, e não se encontravam mais formas definidas de bactérias filamentosas.

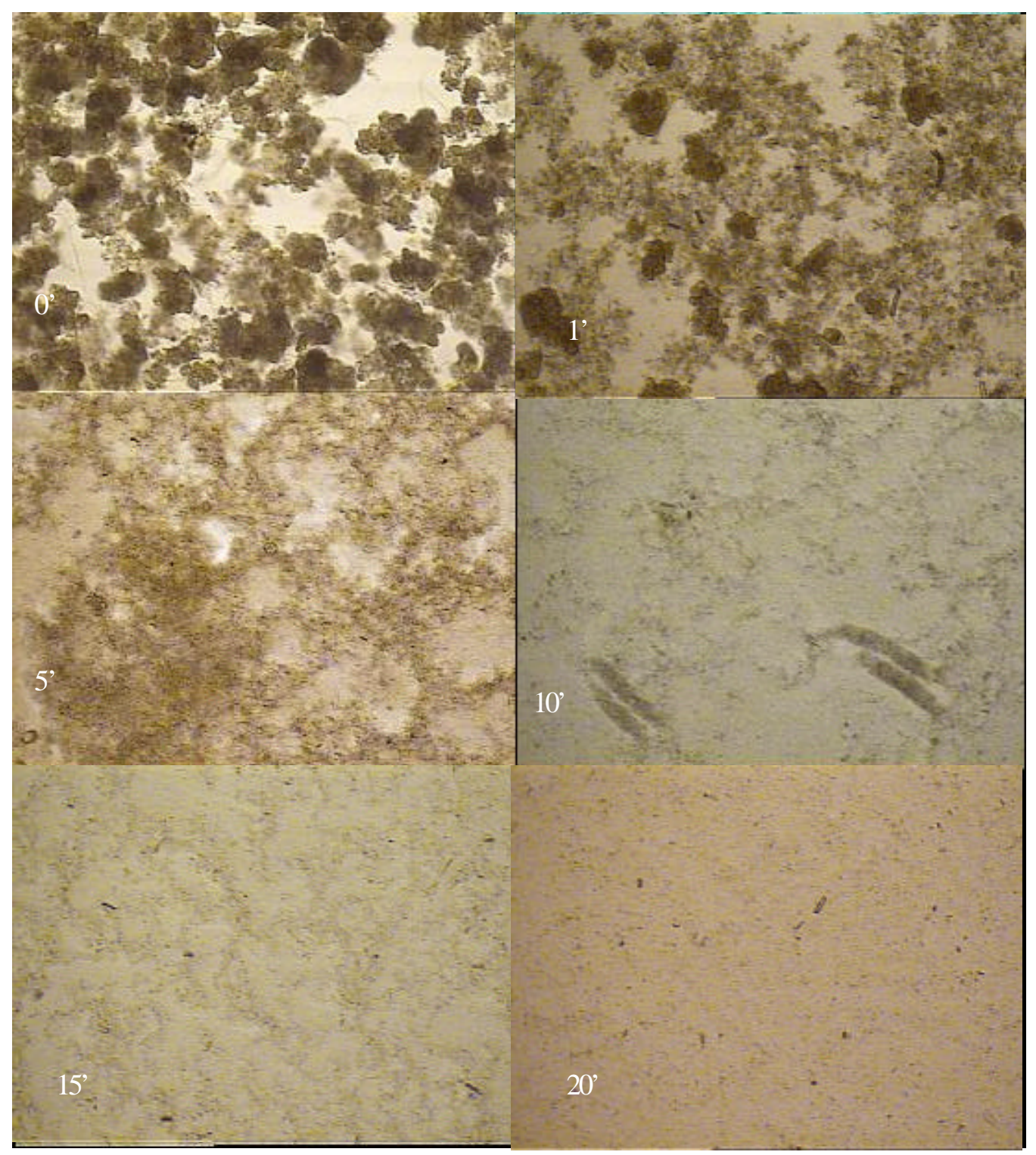

Figura 5. 2- Aspecto do lodo do reator B após exposição ao ultra-som (40x)

No tempo de exposição de 10 minutos, praticamente já não havia a presença de flocos definidos. Não foi encontrada também a presença de alguma morfologia 
conhecida, exceto rotíferos (em quantidade bem menor que no tempo 0). No tempo de 15 minutos, os flocos já haviam se transformado em pequenos filetes de matéria. Não foi observada a presença de nenhuma morfologia conhecida. No tempo de 20 minutos, toda a matéria encontrava-se misturada. Não se podiam definir flocos e nem filetes de matéria.

A figura 5.7 ilustra o comportamento dos lodos antes e depois do ultra-som, após 30 minutos de sedimentação. Pode-se notar que o lodo submetido ao ultra-som (direita) não sofreu sedimentação devido as suas partículas estarem bem mais homogêneas no meio líquido

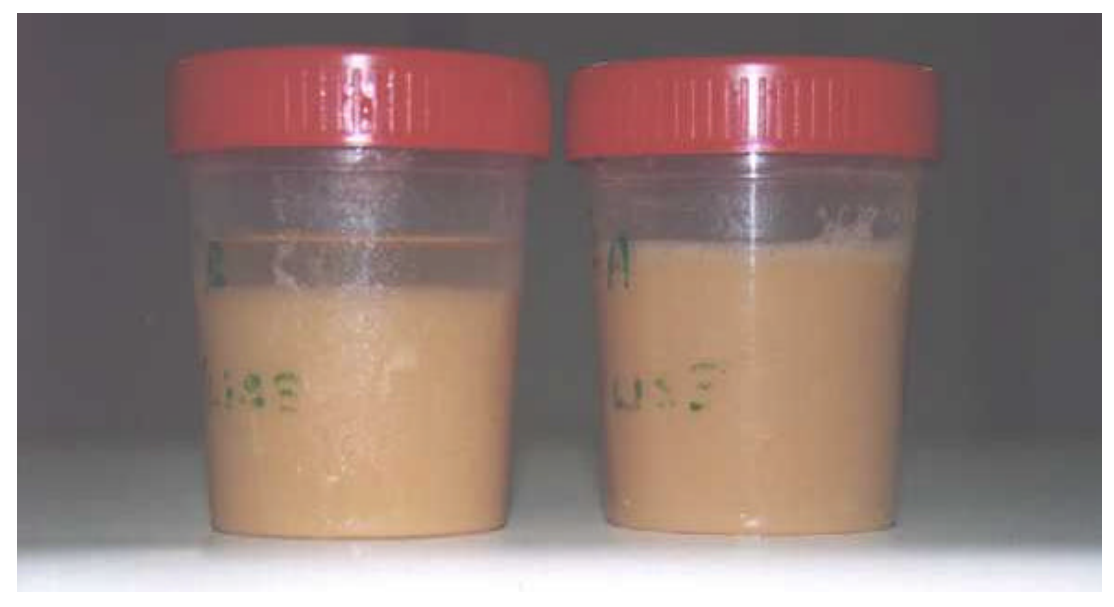

Figura 5. 7-Lodo de descarte antes e depois do ultra-som.

\subsection{Análise de DQO}

Como explicado anteriormente, os resultados serão agrupados por tipo de análise para cada etapa do monitoramento (controle e teste) e para cada reator (A e B), para melhor visualização e comparação dos resultados. 


\subsubsection{Etapa controle}

A figura 5.8 ilustra o comportamento da concentração de entrada e saída do substrato no reator A, em termos de DQO, e sua respectiva eficiência.

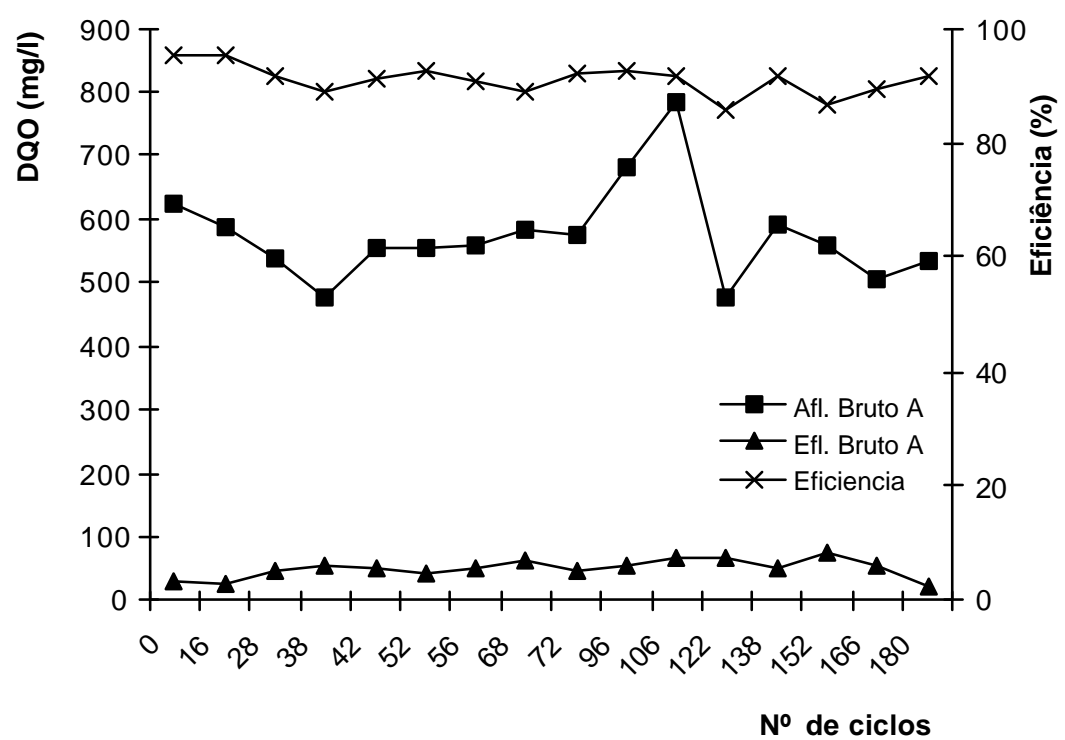

Figura 5. 8- Eficiência de remoção em termos de DQO para o reator A - Etapa controle

Como observado, a eficiência de remoção sempre se situou acima dos $80 \%$, tendo uma média de 90,9\% em termos de remoção de DQO bruta. A concentração média afluente (em termos de DQO bruta) foi de $574 \pm 78 \mathrm{mg} / \mathrm{L}$, e a concentração média de saída foi de $50 \pm 13 \mathrm{mg} / \mathrm{L}$. Já a DQO média filtrada afluente foi de $440 \pm$ $30 \mathrm{mg} / \mathrm{L}$, e efluente de $30 \pm 14 \mathrm{mg} / \mathrm{L}$ DQO. Pode ser observado também que não houve quedas acentuadas nas eficiências, indicando que o reator estava em um bom regime de operação. A figura 5.9 ilustra o comportamento da DQO bruta para o reator $\mathrm{B}$. 


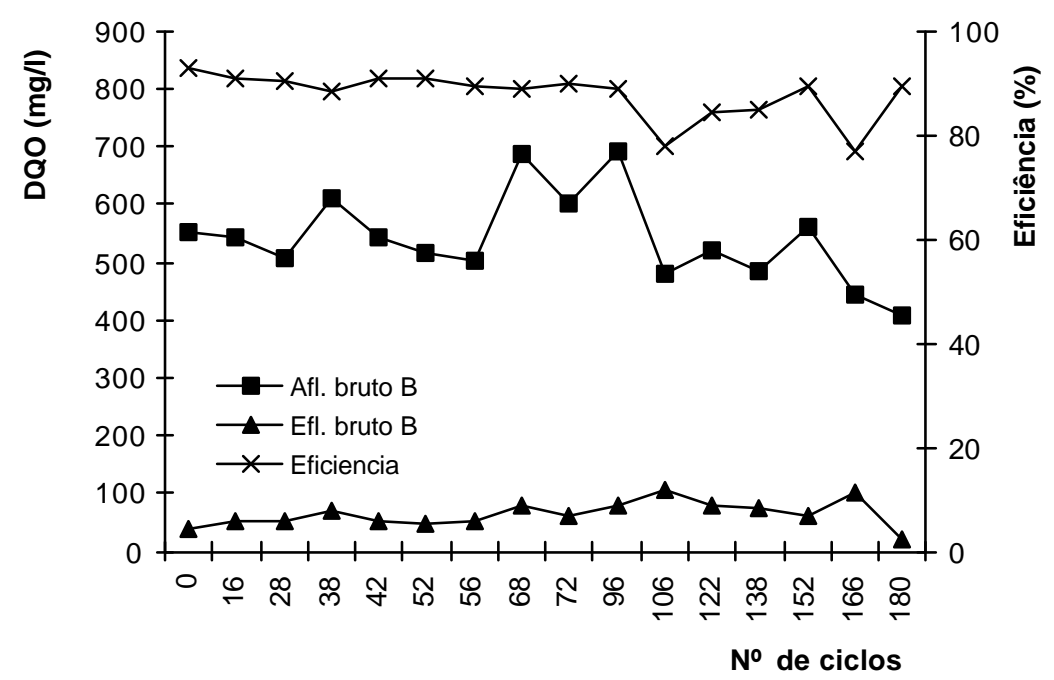

Figura 5. 9 - Eficiência de remoção em termos de DQO para o reator B - Etapa controle

Para o Reator B, a eficiência de remoção em termos de DQO bruta sofreu alterações mais acentuadas que no reator A, porém a eficiência média de remoção de DQO bruta ficou em 87,7\%, o que é muito próxima da eficiência média atingida pelo reator A. Para o reator B, a DQO média bruta afluente foi de $541 \pm 72 \mathrm{mg} / \mathrm{L}$ e a DQO média efluente foi de $64 \pm 20 \mathrm{mg} / \mathrm{L}$. Para a DQO filtrada, a média afluente foi de 406 $\pm 50 \mathrm{mg} / \mathrm{L}$ e a efluente foi de $28 \pm 14 \mathrm{mg} / \mathrm{L}$.

Foi também feito um perfil do consumo de DQO ao longo do tempo de ciclo para os dois reatores. Para amenizar os efeitos da diluição, que certamente iam mascarar os resultados, para o cálculo do consumo de DQO foi seguida a equação 5.1.

$$
D Q O_{D I L}=D Q O_{E} * \frac{9,5}{15}+D Q O_{S} * \frac{9,5}{15}
$$

Em que: $\mathrm{DQO}_{\mathrm{DL}}=\mathrm{DQO}$ corrigida com a diluição;

$\mathrm{DQO}_{\mathrm{E}}=\mathrm{DQO}$ de entrada no reator;

$\mathrm{DQO}_{\mathrm{S}}=\mathrm{DQO}$ de saída do reator. 
Como o reator tem um volume útil de 15 litros e o volume de cada alimentação é de 9,5 litros, necessário se faz um cálculo da DQO de entrada com a diluição. Para isso devemos levar o efeito da variação de volumes quando do enchimento do reator, e o efeito da DQO residual e sua respectiva variação quando do enchimento do reator.

Feito os ajustes, foi elaborado um gráfico da variação temporal da DQO onde foi ajustada uma curva de primeira ordem com residual, por meio do software Origin versão 6.0. A figura 5.10 ilustra o comportamento do consumo da DQO para o reator $\mathrm{A}$.

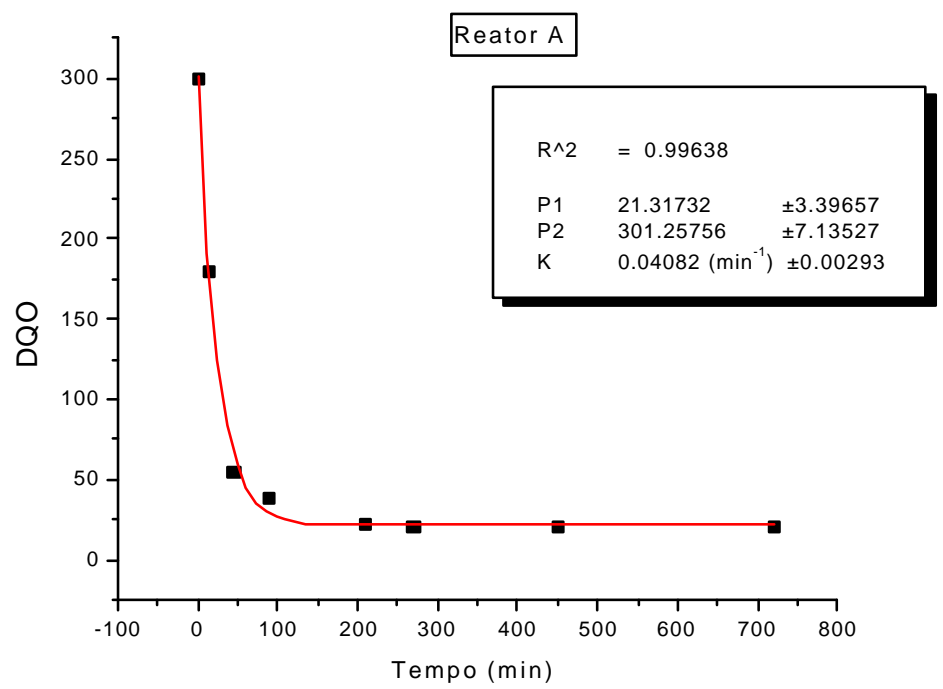

Figura 5. 10- Variação temporal da DQO bruta para o reator A - Etapa controle.

Como pode ser observado, a curva se ajustou ao modelo de primeira ordem com residual: 


$$
\mathrm{Y}=\mathrm{P}_{1}+\left(\mathrm{P}_{2}-\mathrm{P}_{1}\right) \cdot \mathrm{e}^{-\mathrm{kt}}
$$

Em que: $\mathrm{P}_{1}=\mathrm{DQO}$ de entrada $(\mathrm{mg} / \mathrm{l})$;

$$
\begin{aligned}
& \mathrm{P}_{2}=\text { DQO residual }(\mathrm{mg} / \mathrm{l}) ; \\
& \mathrm{k}=\text { coeficiente cinético aparente }\left(\mathrm{min}^{-1}\right) ; \\
& \mathrm{t}=\text { tempo }(\mathrm{min}) .
\end{aligned}
$$

$\mathrm{O}$ valor de $\mathrm{k}$ (coeficiente cinético aparente) foi de $0,04082 \mathrm{~min}^{-1}$, enquanto o valor do coeficiente específico, razão entre o coeficiente aparente e os sólidos suspensos voláteis presentes no reator, foi de $0,02278 \mathrm{~min}^{-1} / \mathrm{gSSV}$.

Para o reator $\mathrm{B}$ foi calculada a diluição também seguindo a seguindo a equação (5.1). O resultado da variação da DQO para o reator B pode ser visto na figura 5.11.

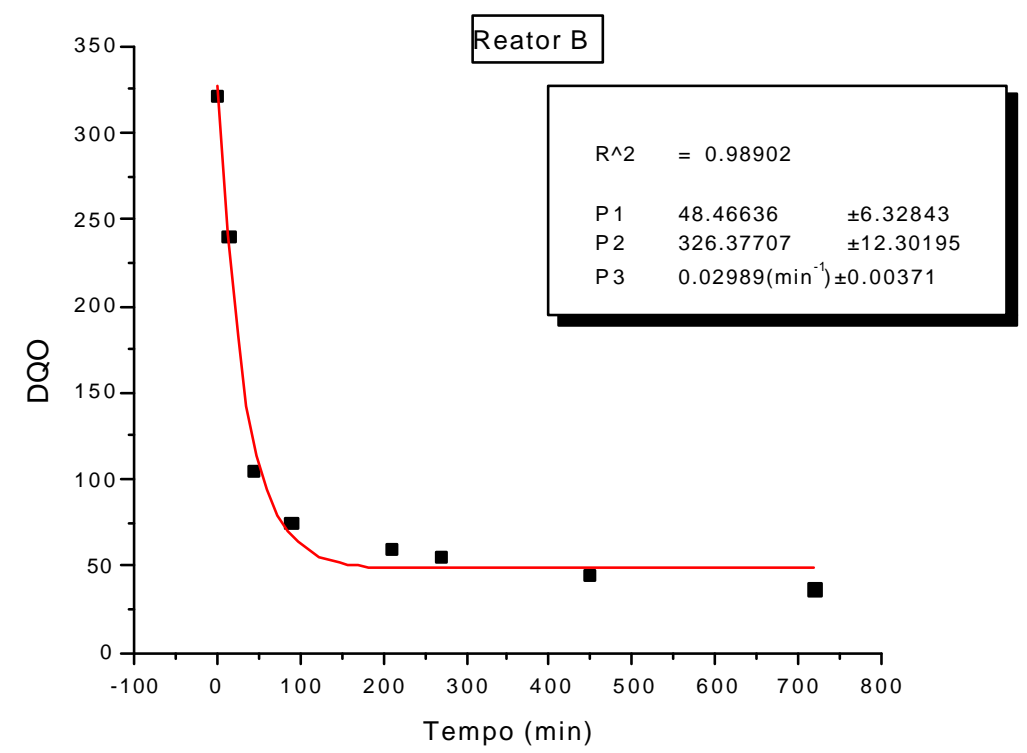

Figura 5. 11- Variação temporal da DQO bruta para o reator B - Etapa controle. 
Como no reator A, a curva apresentou um bom ajuste também para o reator B. Já o valor do coeficiente cinético aparente (k) foi de 0,02989 $\mathrm{min}^{-1}$, e o coeficiente especifico foi de $0,01624 \mathrm{~min}^{-1} / \mathrm{gSSV}$, indicando que o reator $\mathrm{B}$ apresentou uma velocidade de consumo do substrato menor que o reator $\mathrm{A}$ nesta etapa. Isto provavelmente se deve a uma maior concentração, em termos de DQO, no afluente do reator $\mathrm{A}$.

\subsubsection{Etapa teste}

Analisando o reator A com relação a DQO afluente, foi notado um aumento na sua concentração, em comparação a etapa controle, como mostrada na figura 5.12.

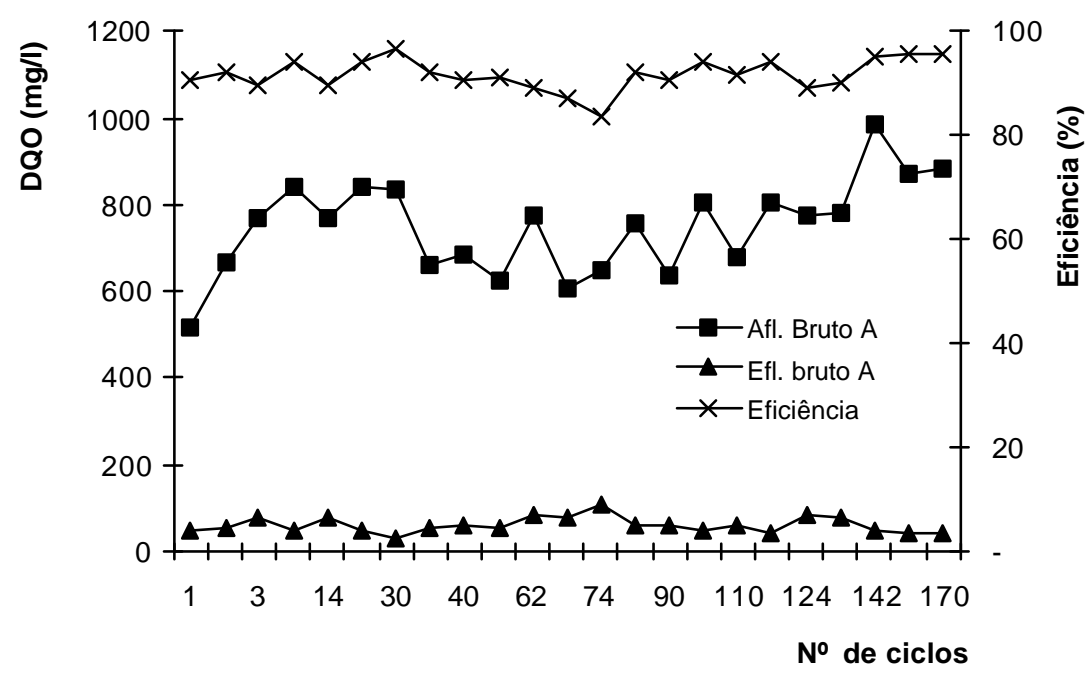

Figura 5. 12- Eficiência de remoção em termos de DQO para o reator A - Etapa teste

A eficiência de remoção em termos de DQO bruta foi de $92 \%$. Houve um aumento na eficiência, ainda que pequeno, se comparado ao reator A da etapa controle. A concentração média bruta afluente foi de $749 \pm 109 \mathrm{mg} / \mathrm{L}$, e a concentração média de saída foi de $60+19 \mathrm{mg} / \mathrm{L}$. Para a DQO filtrada, a 
concentração média afluente foi de $362 \pm 68 \mathrm{mg} / \mathrm{L}$ a média efluente foi de $32 \pm$ $11 \mathrm{mg} / \mathrm{L}$. O aumento da concentração afluente se deve ao fato da inclusão do lodo de excesso após aplicação do ultra-som. Notou-se uma maior variação nas concentrações afluente devido ao fato que a concentração de retorno do lodo lisado nunca é a mesma. Entretanto notou-se também que, apesar das variações da concentração afluente, não houve variações significativas na eficiência.

Para o reator $\mathrm{B}$, a figura 5.13 ilustra o comportamento da concentração afluente e efluente, assim como a eficiência de remoção.

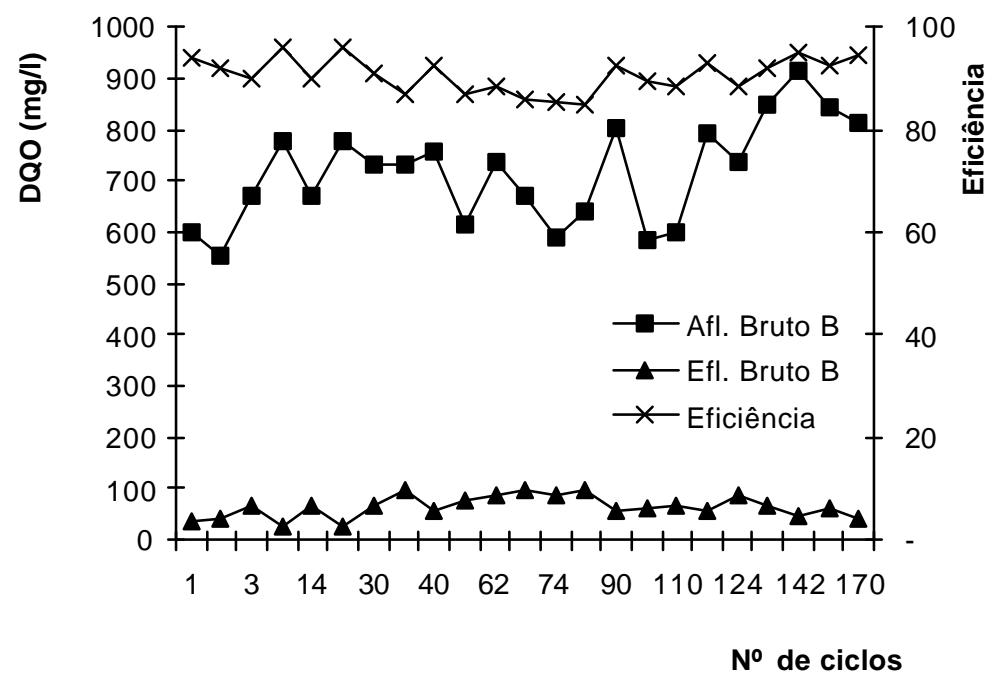

Figura 5. 13- Eficiência de remoção em termos de DQO para o reator B - Etapa teste

O reator B apresentou uma eficiência média de remoção de DQO bruta de 91\%, a qual também é ligeiramente maior que a eficiência do reator B para a etapa controle. Como esperado, a DQO afluente sofreu um acréscimo devido ao retorno do lodo e a média da DQO bruta afluente foi de $716 \pm 99 \mathrm{mg} / \mathrm{L}$ e DQO filtrada afluente foi de $363 \pm 67 \mathrm{mg} / \mathrm{L}$. Notou-se também uma variação da DQO afluente devido ao retorno do lodo desintegrado pelo ultra-som. Entretanto essas variações foram 
amortecidas pelo reator que sempre lançava um efluente com baixa concentração em termos de DQO, com a média de $64 \pm 20 \mathrm{mg} / \mathrm{L}$.

Nota-se que os valores da DQO filtrada afluente para a etapa teste foram menores que os valores para a etapa controle. Isso pode ser devido ao fato da liberação de polímeros quando da aplicação do ultra-som ao lodo em excesso e seu retorno ao tanque de aeração. Os polímeros agem como aglomerantes dos sólidos presentes no tanque de alimentação e dificultam a filtração da amostra, diminuindo a passagem de sólidos que anteriormente passariam pelo mesmo diâmetro do poro da membrana.

Também na etapa teste foram feitos perfis temporais para se verificar a degradação da matéria orgânica em termos de DQO. Aqui também foi levado em conta o efeito da diluição para não mascarar os resultados da constante cinética aparente. A figura 5.14 ilustra o decaimento da DQO ao longo do tempo.

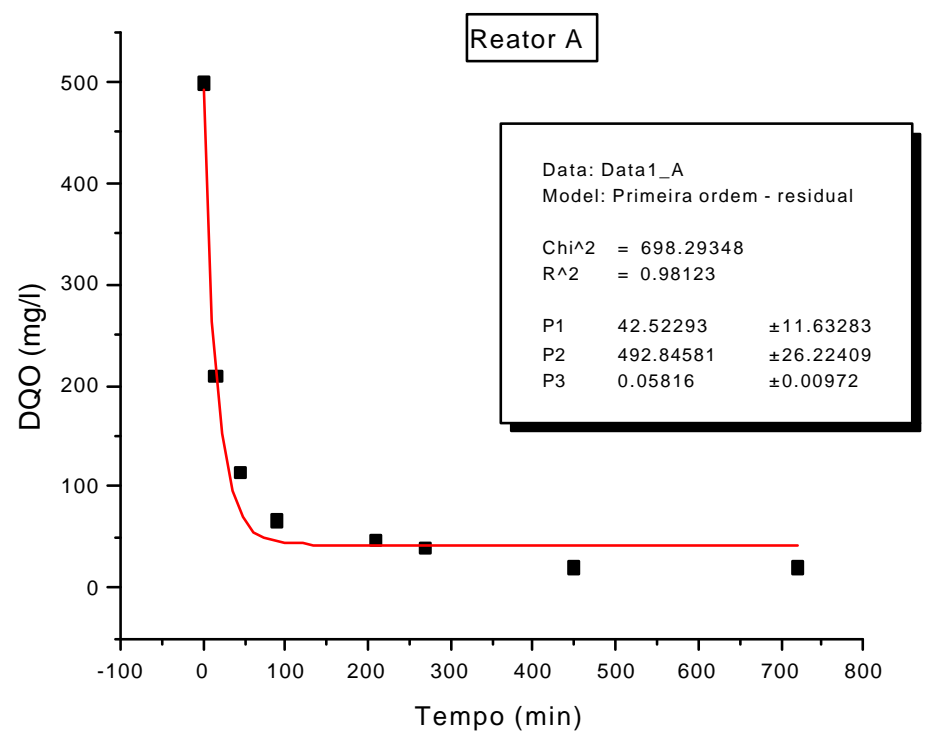

Figura 5. 14 Variação temporal da DQO bruta para o reator A - Etapa teste. 
O consumo da DQO bruta também aconteceu nas três primeiras horas do ciclo de doze horas, da mesma maneira como ocorreu na etapa controle. O modelo de primeira ordem com residual (equação 5.2) também apresentou uma boa correlação. Pode-se notar um aumento no valor do coeficiente cinético aparente para 0,05816 $\mathrm{min}^{-1}$, e o coeficiente específico foi de $0,01813 \mathrm{~min}^{-1} / \mathrm{mgSSV}$., indicando que a velocidade de consumo praticamente não variou com o aumento da DQO de entrada, devido a uma maior concentração de sólidos no reator durante a etapa teste.

Já para o reator B, a figura 5.15 ilustra o decaimento da DQO ao longo do tempo.

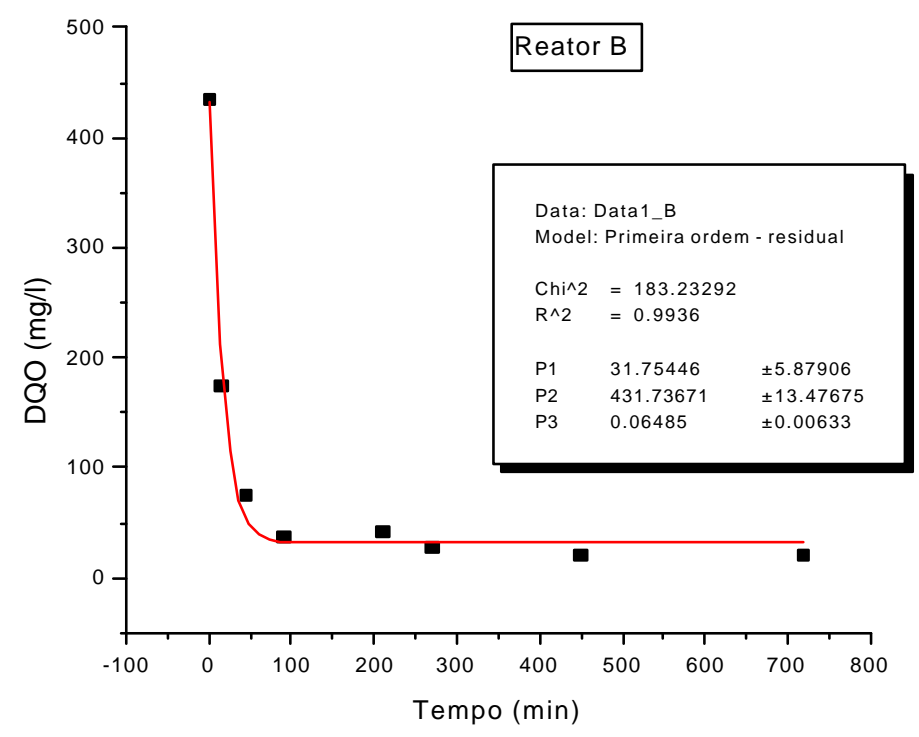

Figura 5. 15- Variação temporal da DQO bruta para o reator B - Etapa teste.

Também para o reator $\mathrm{B}$ houve um bom ajuste da curva de primeira ordem com residual. $\mathrm{O}$ valor do coeficiente cinético aparente sofreu um aumento considerável $\left(\mathrm{k}=0.06485 \mathrm{~min}^{-1}\right)$ e o valor do coeficiente específico foi de 0,26086 $\min ^{-1} / \mathrm{gSSV}$, em relação ao valor da constante para a etapa controle. 
Esse aumento pode ser devido a uma melhor desintegração do lodo de retorno do reator $\mathrm{B}$, pois a concentração de lodo a ser desintegrada é maior no reator B que no reator A devido a menor idade do lodo. Com uma maior DQO de entrada e uma maior disponibilidade de substrato altamente biodegradável, houve um aumento no coeficiente específico.

\subsection{Análise de sólidos}

Para melhor visualização, os gráficos estarão contemplando o comportamento dos dois reatores para cada etapa de monitoramento (controle e teste).

\subsection{1 etapa controle}

Quanto ao teor de sólidos presentes no afluente dos reatores, a figura 5.16 ilustra esse comportamento. Vale ressaltar que os teores de sólidos estão em termos de sólidos suspensos voláteis.

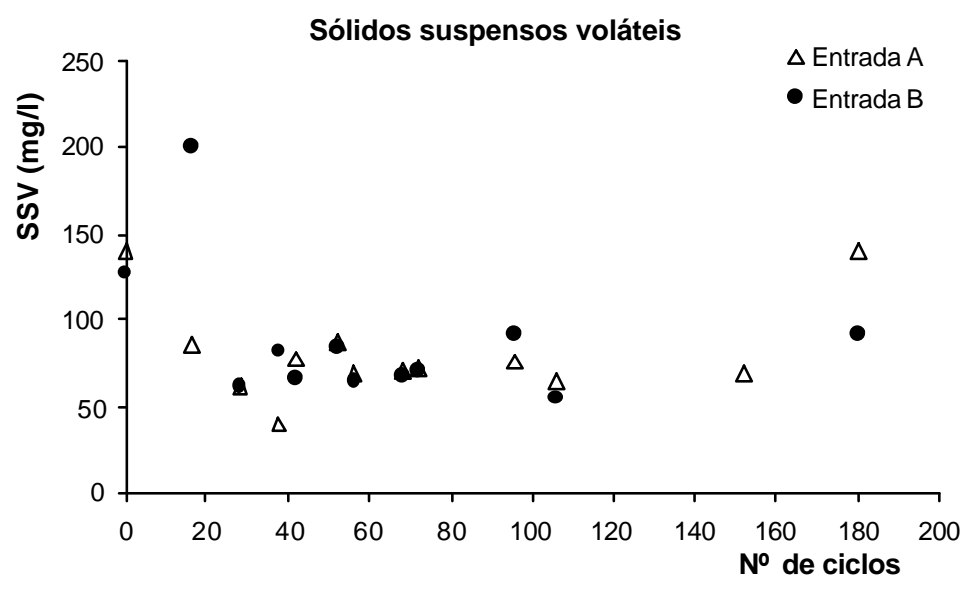

Figura 5. 16- Sólidos suspensos voláteis afluente para os reatores A e B - Etapa controle. 
A concentração média de sólidos suspensos voláteis para o reator A foi de

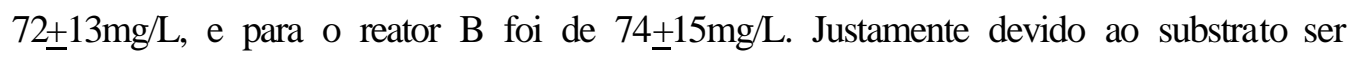
sintético, pôde-se notar uma constância no teor de sólidos suspensos voláteis no afluente dos reatores A e B para a etapa controle

Quanto ao comportamento do teor de sólidos suspensos voláteis no tanque de aeração dos reatores $\mathrm{A}$ e $\mathrm{B}$, a figura 5.17 indica esse comportamento.

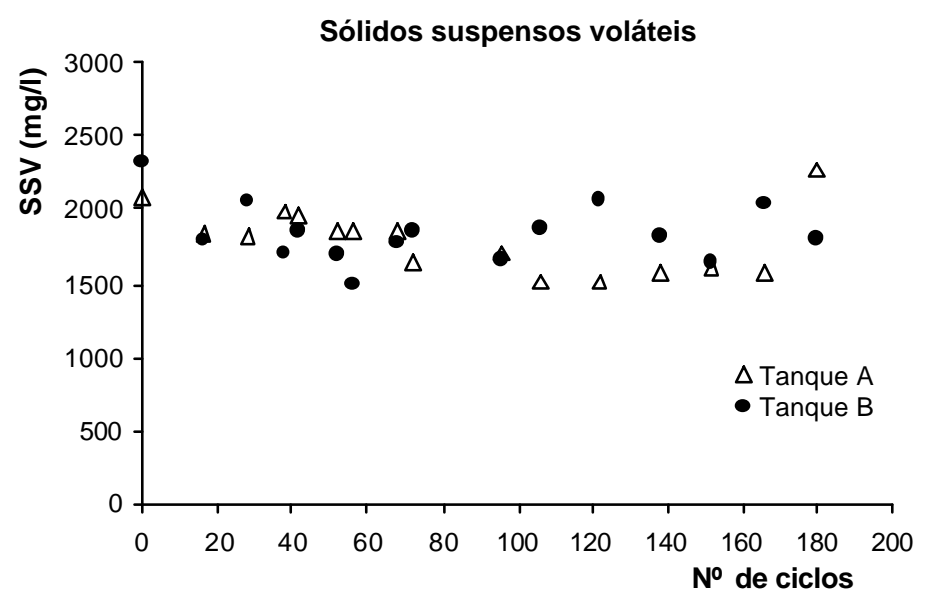

Figura 5. 17- Sólidos suspensos voláteis nos tanques dos reatores A e B - Etapa controle

Pode-se observar que o teor dos sólidos suspensos voláteis no interior dos tanques A e B variavam em uma função mais ou menos cíclica (aumento e diminuição da concentração), mas permaneceram sempre no patamar médio de $1792 \pm 218 \mathrm{mg} / \mathrm{L}$ para o reator A, e de $1841 \pm 202 \mathrm{mg} / \mathrm{L}$ para o reator B. Pode-se inferir também que a variação se deveu ao equilíbrio dinâmico da biomassa.

Com relação ao teor de sólidos suspensos no efluente dos reatores A e B, a figura 5.18 fornece esse comportamento. 


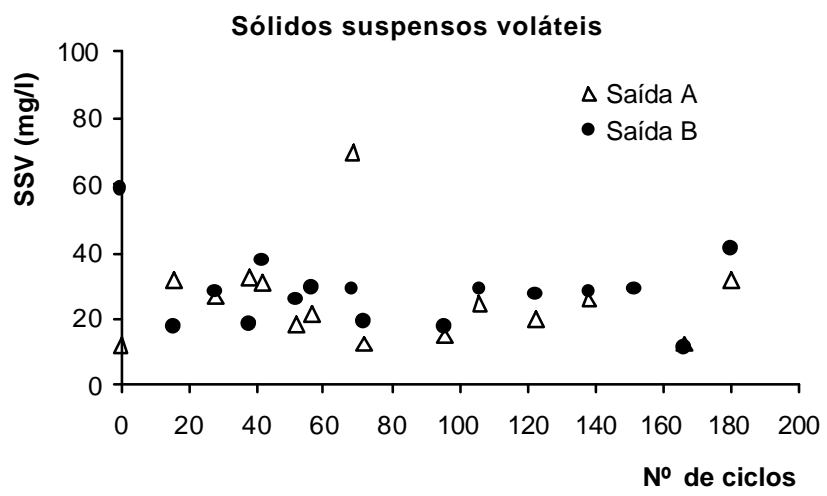

Figura 5. 18- Sólidos suspensos voláteis efluente para os reatores A e B - Etapa controle.

Verificou-se, pela análise do teor de sólidos no efluente dos dois reatores, que o lodo apresentava uma boa sedimentação. A média das concentrações de sólidos suspensos no efluente do reator A foi de $24 \pm 16 \mathrm{mg} / \mathrm{l}$, e para o reator B foi de $28+11 \mathrm{mg} /$ l. Nota-se o comportamento semelhante dos dois reatores quanto ao teor de sólidos no tanque de aeração e no efluente dos sistemas, independente da idade do lodo.

Quanto a relação sólidos suspensos fixos e sólidos suspensos voláteis (SSF/SSV) para o afluente dos reatores, a figura 5.19 ilustra o comportamento.

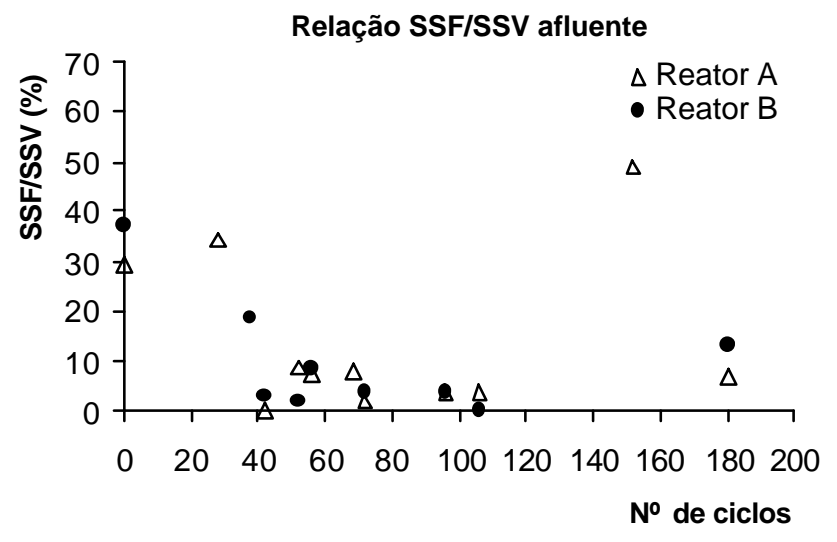

Figura 5. 19- Relação SSF/SSV afluente para os reatores A e B - Etapa controle. 
Como se pode notar, as relações SSF/SSV afluente para os reatores A e B sofreram variações ao longo do tempo. Essas variações provavelmente foram devidas a erros de pesagem dos componentes que compõem o substrato por causa das pequenas massas e pequenos volumes empregados, o que gerava essa variação, tanto nas relações citadas quanto na variação da DQO.

$\mathrm{O}$ afluente do reator $\mathrm{A}$ obteve uma relação média de $14 \%$, enquanto que o reator B obteve uma média de $10 \%$ de relação SSF/SSV.

Para a relação no efluente dos reatores, a figura 5.20 ilustra o comportamento.

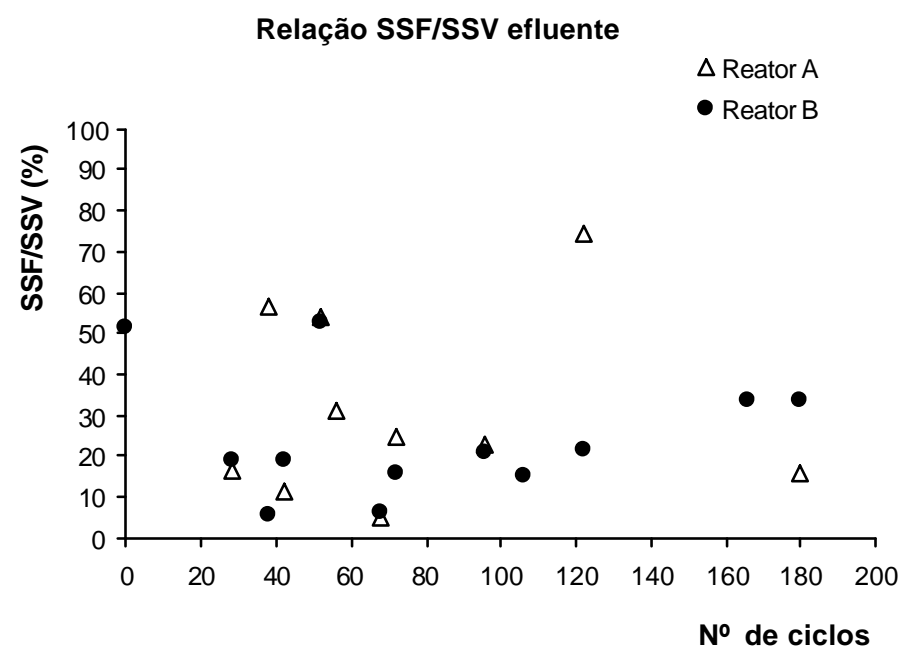

Figura 5. 20- Relação SSF/SSV efluente para os reatores A e B - Etapa controle.

Importante notar o aumento na relação SSF/SSV efluente para os dois reatores, indicando uma mineralização da matéria. A relação média SSF/SSV para o reator A foi de $31 \%$ e para o reator B foi de $25 \%$. Como o reator A tem uma maior idade do lodo, já era de se esperar uma maior mineralização da matéria afluente em relação ao reator B. 
Com relação aos tanques de aeração, a figura 5.21 ilustra o comportamento da relação SSF/SSV. Pode-se notar que a relação praticamente permaneceu constante por toda a etapa controle e muito semelhante entre os dois reatores. A relação média para o reator A foi de $19 \%$, enquanto que para o reator B essa relação foi de $18 \%$.

Relação SSF/SSV tanque de aeração

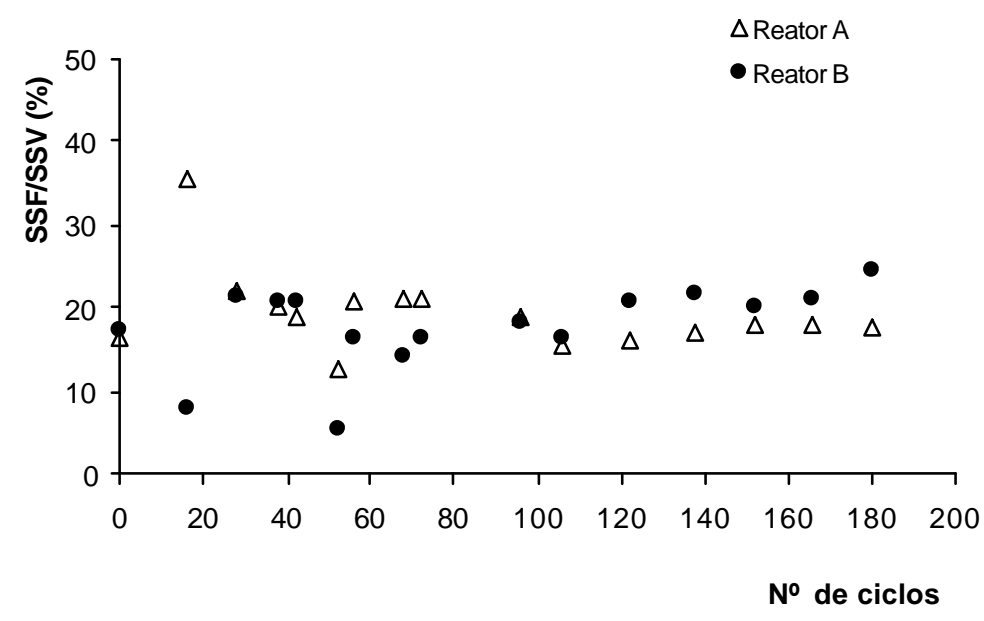

Figura 5. 21-Relação SSF/SSV no tanque de aeração dos reatores A e B - Etapa controle.

Com relação ao IVL, pode-se verifica o comportamento dos dois reatores na figura 5.22.

IVL

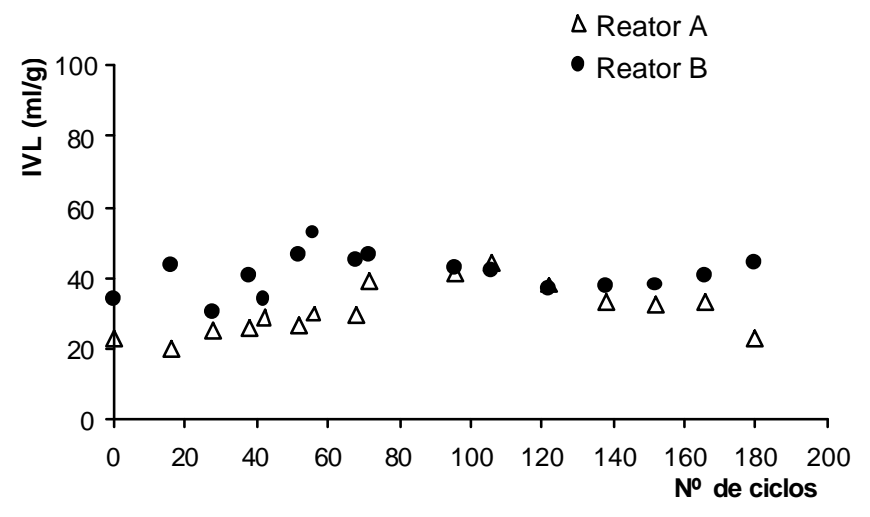

Figura 5. 22- Índice Volumétrico do lodo para os reatores A e B - Etapa controle. 
Os dois reatores apresentaram um bom resultado para o IVL durante toda a etapa controle, apresentando um IVL médio de $31 \mathrm{ml} / \mathrm{g}$ para o reator A, e $41 \mathrm{ml} / \mathrm{g}$ para o reator $\mathrm{B}$, bem abaixo da faixa recomendada para se evitar bulking, que é em torno de $300 \mathrm{ml} / \mathrm{g}$.

Outro fator importante no controle dos reatores é a produção de lodo e o crescimento aparente da biomassa ( $\mathrm{Y}_{\mathrm{obs}}$ ). $\mathrm{O}$ cálculo da produção acumulada de lodo, foi realizado de acordo com a equação (5.3) e (5.4):

$$
\begin{aligned}
& \mathrm{Px}=\mathrm{V}_{\mathrm{R}} \cdot \mathrm{SSV}_{\mathrm{R}}+\mathrm{V}_{\mathrm{E} \cdot S S V_{\mathrm{E}}} \\
& P x_{A C}=\sum_{n=1}^{i} P x n
\end{aligned}
$$

Em que: Px = Produção de lodo (SSV);

$\mathrm{V}_{\mathrm{R}}=$ Volume de retirada do lodo em excesso $(\mathrm{L})$;

$\mathrm{SSV}_{\mathrm{R}}=$ Concentração no lodo em excesso (mgSSV/L);

$\mathrm{V}_{\mathrm{E}}=$ Volume do efluente $(\mathrm{L})$;

$\mathrm{SSV}_{\mathrm{E}}=$ Concentração no efluente $(\mathrm{mgSSV} / \mathrm{L})$;

$\mathrm{Px}_{\mathrm{AC}}=$ Produção de lodo acumulado;

$\mathrm{n}=$ número de ciclos.

Para o cálculo do consumo acumulado de DQO, utilizou-se as equações (5.5) e (5.6):

$$
\begin{gathered}
\mathrm{DQO}_{\mathrm{R}}=\left(\mathrm{DQO}_{\mathrm{A}}-\mathrm{DQO}_{\mathrm{E}}\right) \cdot \mathrm{V}_{\mathrm{E}} \\
D Q O_{A C}=\sum_{n=1}^{i} D Q O_{R} n
\end{gathered}
$$

Em que: $\mathrm{DQO}_{\mathrm{R}}=\mathrm{DQO}$ removida no reator $(\mathrm{mg})$;

$$
\begin{aligned}
& \mathrm{DQO}_{\mathrm{A}}=\mathrm{DQO} \text { afluente }(\mathrm{mg} / \mathrm{L}) \\
& \mathrm{DQO}_{\mathrm{E}}=\mathrm{DQO} \text { efluente }(\mathrm{mg} / \mathrm{L}) ;
\end{aligned}
$$


$\mathrm{DQO}_{\mathrm{AC}}=$ Remoção acumulada de DQO (mg);

$\mathrm{V}_{\mathrm{E}}=$ Volume do efluente;

$\mathrm{n}=$ Número de ciclos.

Para o cálculo da produção observada de lodo por DQO removida, faz-se uso da equação (5.7):

$$
Y_{o b s}=\frac{P x}{D Q O_{R}}
$$

Em que: $\mathrm{Y}_{\mathrm{obs}}=$ Produção de lodo por DQO removida (mgSSV/mg);

Px = Produção de lodo (SSV);

$\mathrm{DQO}_{\mathrm{R}}=\mathrm{DQO}$ removida no reator $(\mathrm{mg})$.

Com ajuda das equações acima citadas, pôde-se montar um gráfico do Yobs para o reator A, conforme a figura 5.23.

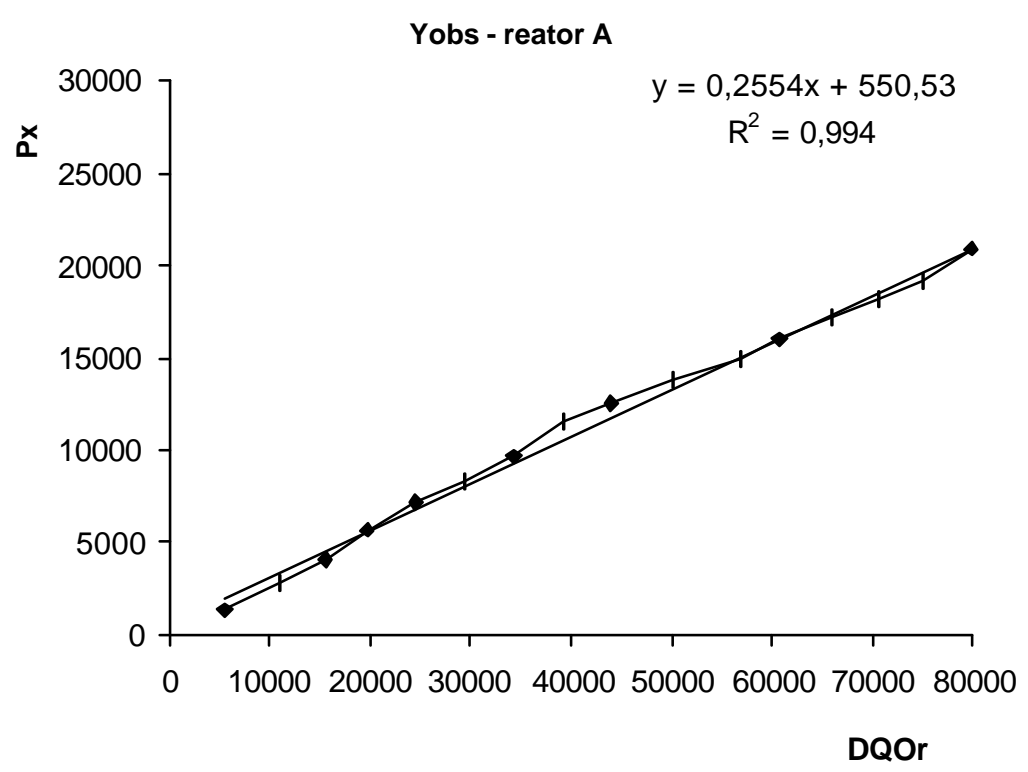

Figura 5. 23- Produção de lodo $\left(\mathrm{Y}_{\mathrm{obs}}\right)$ para o reator A - Etapa controle. 
Pode-se notar que a produção de lodo por DQO removida foi de 0,26 mgSSV/mg, abaixo da faixa citada em literatura para sistemas aeróbios, que é situada em tomo de 0,5 .

Para o reator B, a figura 5.24 ilustra o comportamento da produção de lodo por DQO removida.

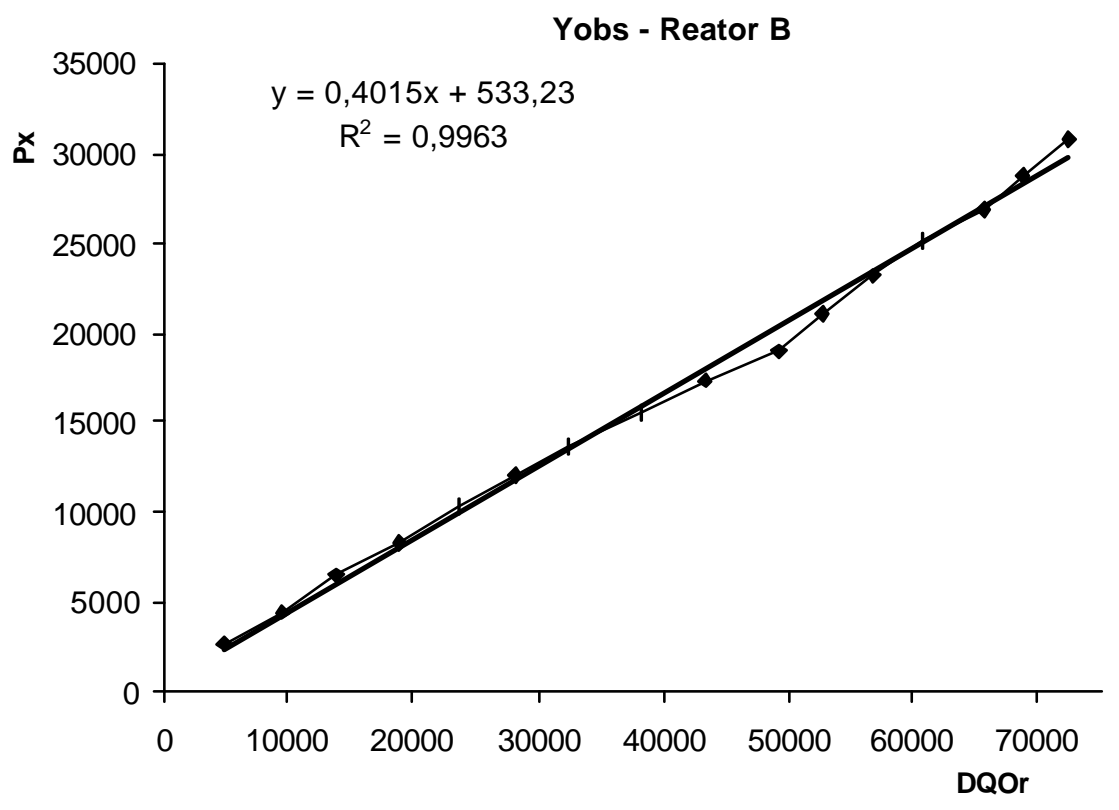

Figura 5. 24- Produção de lodo ( $\left.\mathrm{Y}_{\mathrm{obs}}\right)$ para o reator B - Etapa controle.

Pode-se notar que o valor do $\mathrm{Y}_{\mathrm{obs}}$ para o reator $\mathrm{B}$ foi maior que em relação ao reator A. Este fato pode ser explicado pela maior idade do lodo do reator A. Mesmo assim ainda está abaixo da faixa relatada pela literatura.

\subsubsection{Etapa teste}

Nesta etapa deve ser lembrado que houve a aplicação do ultra-som no lodo em excesso dos reatores e posterior retorno desse lodo ao respectivo afluente. 
Com relação ao teor de sólidos suspensos afluente, a figura 5.25 ilustra o comportamento.

Sólidos suspensos voláteis

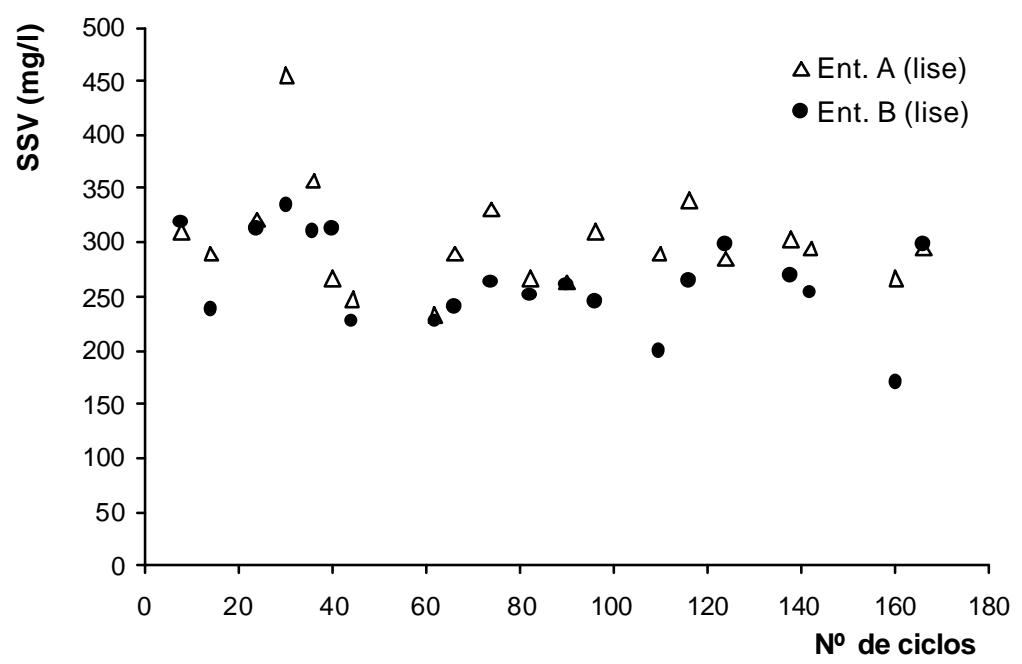

Figura 5. 25- Sólidos suspensos voláteis afluente para os reatores A e B - Etapa teste.

Devido ao retorno do lodo desintegrado ao afluente de seu respectivo reator, era de se esperar um aumento no teor de sólidos suspensos voláteis. A concentração média dos sólidos suspensos voláteis para o afluente do reator A foi de $292 \pm 47 \mathrm{mg} / \mathrm{L}$ (contra $72 \pm 13 \mathrm{mg} / \mathrm{L}$ do controle), e para o reator B foi de $260 \pm 43 \mathrm{mg} / \mathrm{L}$

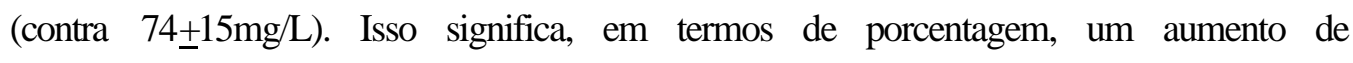
cerca $300 \%$ no teor de sólidos que entram no reator A, e um aumento de $250 \%$ no teor de sólidos para o reator B.

Já a concentração, em termos de sólidos suspensos voláteis, no interior dos reatores é mostrada pela figura 5.26. 


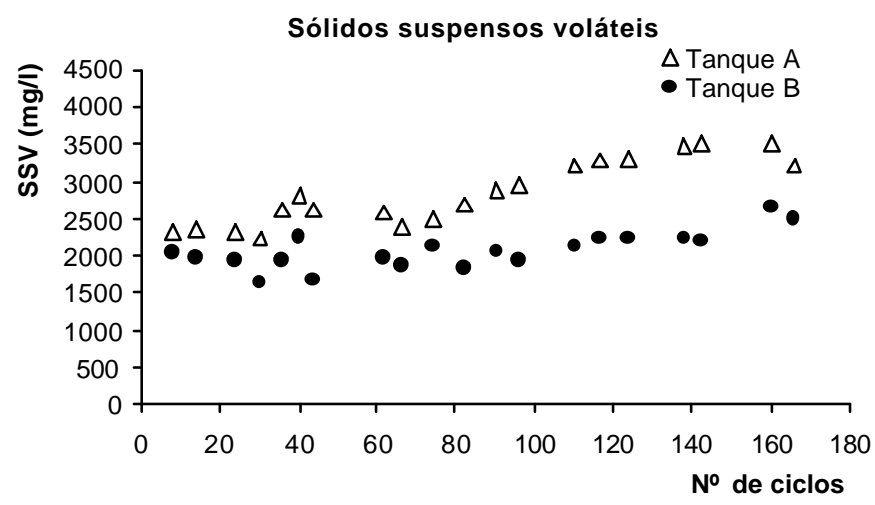

Figura 5. 26- Sólidos suspensos voláteis no nos tanques dos reatores A e B - Etapa teste.

Com o aumento da DQO e da concentração de sólidos afluente, era de se esperar também um aumento na concentração de sólidos suspensos voláteis no interior do reator devido a maior presença de matéria orgânica disponível pra degradação.

Comparando com a etapa experimental, nesta etapa também houve uma variação de forma cíclica (aumento e diminuição da concentração ao longo do tempo de ciclo), principalmente no reator B. Para o reator A essa variação cíclica foi somente até $\mathrm{o} 100^{\circ}$ ciclo aproximadamente. A partir desse ponto, a concentração no reator A começou a subir, ainda que de forma lenta. Nota-se uma tendência de estabilização, e até mesmo queda no teor de sólidos suspensos voláteis a partir do $140^{\circ}$ ciclo. Entretanto não se pode afirmar que a tendência seria mantida visto que o experimento precisou ser interrompido no $166^{\circ}$ ciclo por motivos de força maior.A concentração média de sólidos no reator. A foi de $2749 \pm 436 \mathrm{mg} / \mathrm{L}$, e de $2057 \pm 249 \mathrm{mg} / \mathrm{L}$ para o reator B.

Importante citar também que o teor de sólidos suspensos voláteis no interior do reator na etapa teste foi maior para o reator A que para o reator B. Isso se deve ao 
fato que o teor de sólidos na entrada do reator $\mathrm{A}$ foi também maior, além da concentração em termos de DQO também ter sido. Isso pode ser explicado pelo fato de a desintegração não ser igual para cada tipo de lodo. $\mathrm{O}$ lodo do reator $\mathrm{A}$ se mostrou menos "suscetível" ao ultra-som que o lodo do reator B. Além disso, com o aumento de biomassa, gerava também um aumento da DQO e aumento no teor de sólidos na amostra que ia para o ultra-som.

No que diz respeito ao teor de sólidos suspensos voláteis na saída dos reatores, a figura 5.27 ilustra esse comportamento.

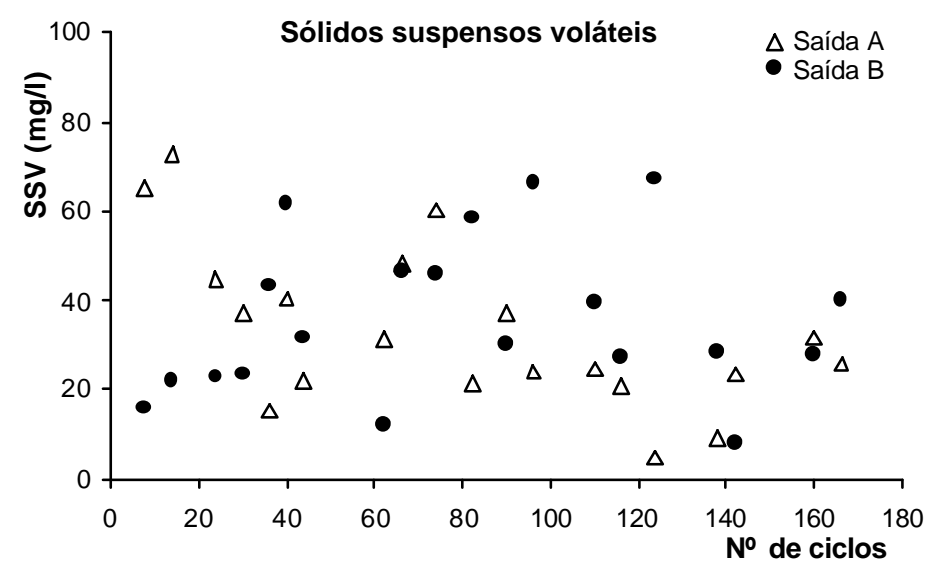

Figura 5. 27- Sólidos suspensos voláteis efluente para os reatores A e B - Etapa teste.

Em comparação com a etapa controle, o teor de sólidos suspensos voláteis na saída dos reatores A e B sofreu um pequeno acréscimo. A concentração média na saída do reator A ficou em $28 \pm 18 \mathrm{mg} / \mathrm{L}$ (contra $24 \pm 16 \mathrm{mg} / \mathrm{L}$ da etapa controle). Já para o reator $\mathrm{B}$, a concentração média de sólidos suspensos voláteis foi de $31 \pm 18 \mathrm{mg} / \mathrm{L}$ (contra $28 \pm 11 \mathrm{mg} / \mathrm{L})$. Foi verificada também um maior desvio nas médias dos efluentes para a etapa teste indicando que a saída já não era tão constante quanto na etapa controle, principalmente devido a entrada que também sofria 
variações de acordo com a quantidade de lodo desintegrada que era adicionada ao efluente.

A relação SSF/SSV no afluente dos reatores A e B para a etapa teste pode ser vista na figura 5.28.

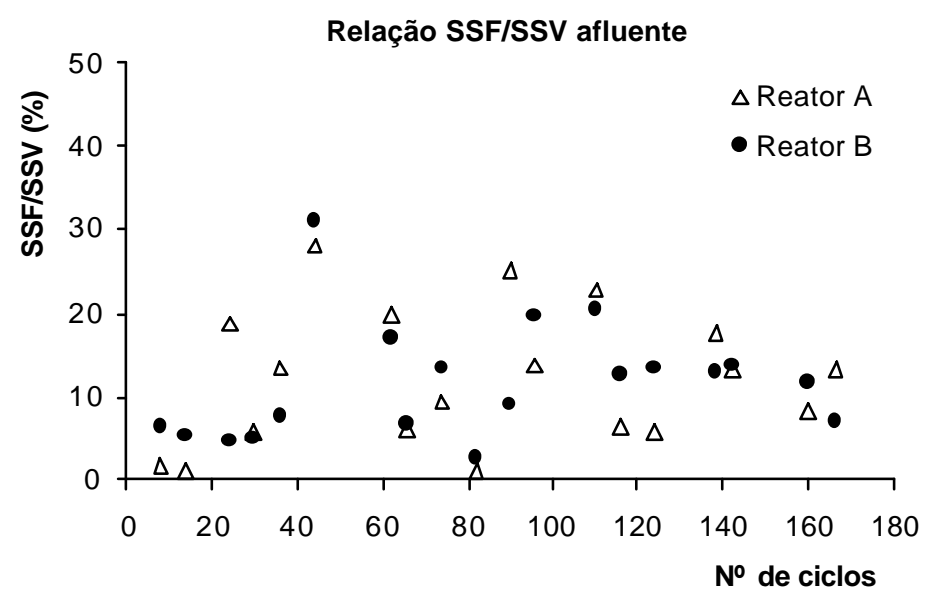

Figura 5. 28- Relação SSF/SSV afluente para os reatores A e B - Etapa teste.

Devido ao retorno do lodo após a desintegração com ultra-som e esse retorno não ter uma certa regularidade na concentração de sólidos, pode-se notar que a relação SSF/SSV sofreu variações ao longo do tempo. O efluente do reator A apresentou uma relação média SSF/SSV de 12\%, abaixo da relação média para a etapa controle, indicando que o reator não recirculava matéria mineral. Para o reator B a relação média foi também de $12 \%$, um pouco acima da média para a etapa controle.

Com referência a relação SSF/SSV no efluente dos reatores A e B, a figura 5.29 ilustra o comportamento. 


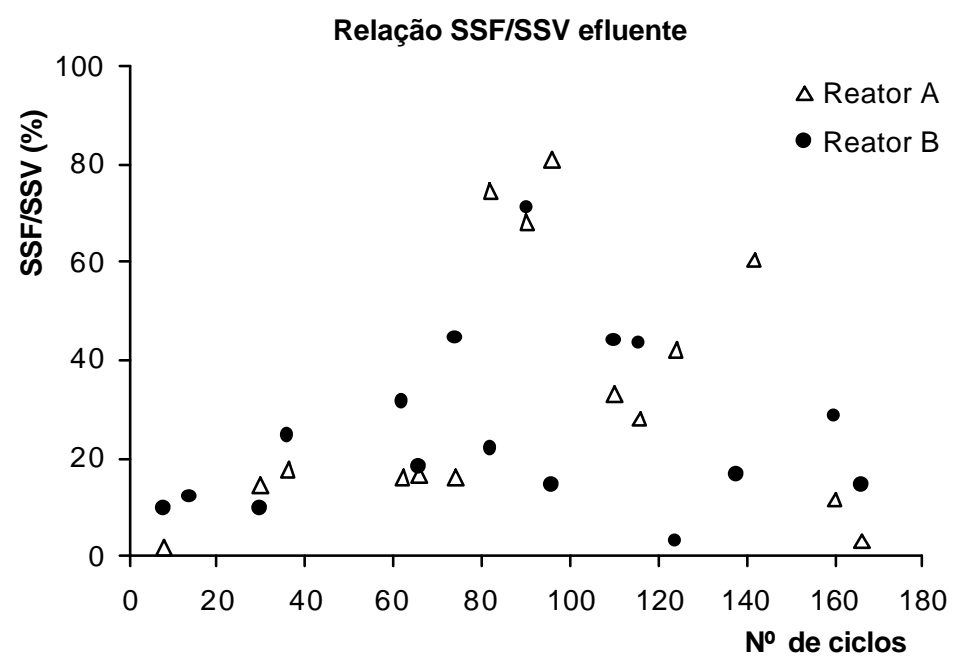

Figura 5. 29- Relação SSF/SSV efluente para os reatores A e B - Etapa teste.

Como observado na figura 5.29, a relação SSF/SSV tendeu a aumentar com o tempo de duração da etapa teste, indicando que mais matéria mineralizada foi expulsa do reator, evitando assim seu acúmulo nos tanques de aeração quando da recirculação do lodo desintegrado. A relação média para o reator A foi de $32 \%$, enquanto que para o reator B essa relação foi de $25 \%$. Pode-se notar ainda que a relação é maior para o reator A que para o reator B devido a maior idade do lodo no reator A.

Importante notar também que a recirculação do lodo desintegrado não afetou a relação SSF/SSV se comparado com os valores da etapa controle (31\% para o reator $\mathrm{A}$ e $25 \%$ para o reator $\mathrm{B})$.

A relação SSF/SSV para o tanque de aeração está ilustrada na figura 5.30. 


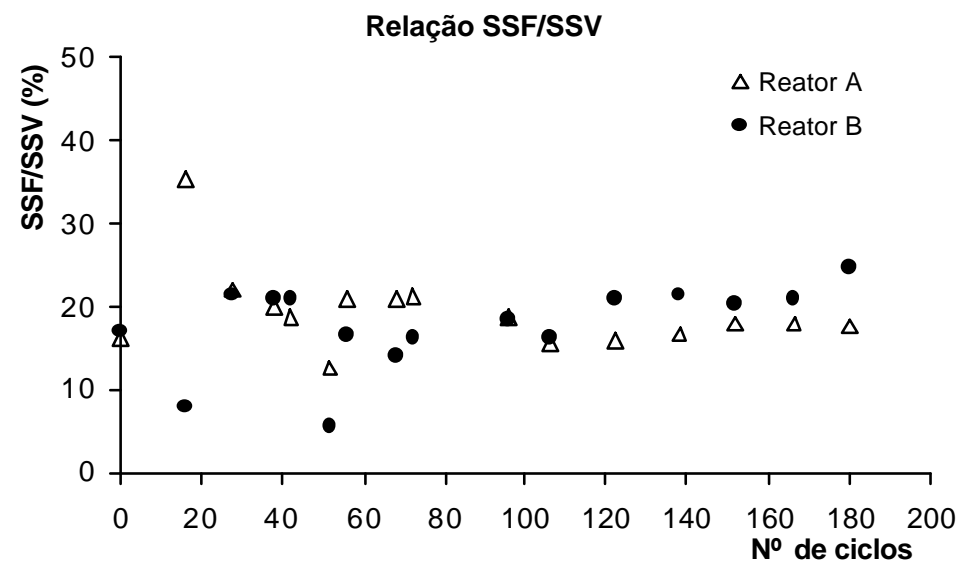

Figura 5. 30- Relação SSF/SSV no tanque de aeração dos reatores A e B - Etapa teste.

Nota-se que, mais uma vez, os reatores tiveram comportamentos semelhantes ao longo da etapa teste. Houve variações cíclicas na relação SSF/SSV para os dois reatores se comparado com a etapa teste, e a relação média foi de $12 \%$ para o reator A e de $14 \%$ para o reator B. Essas relações indicam que não houve acúmulo de sólidos suspensos fixos no tanque de aeração dos reatores, o que poderia diminuir as suas eficiências. Com relação ao IVL, a figura 5.31 ilustra o comportamento durante a etapa teste.

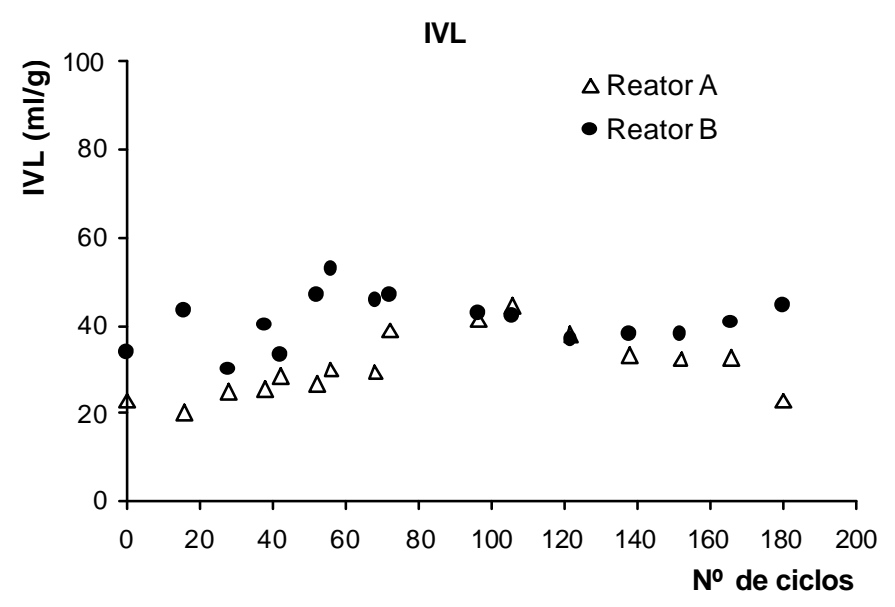

Figura 5. 31- Índice Volumétrico do lodo dos reatores A e B - Etapa teste. 
Os dois reatores continuaram apresentando bons resultados para IVL também na etapa teste. O reator A apresentou um valor médio de $29 \mathrm{ml} / \mathrm{g}$, muito semelhante ao da etapa controle, mesmo com um aumento no teor de sólidos no tanque de aeração. Já o reator B apresentou um acréscimo no valor médio do IVL (56 $\mathrm{ml} / \mathrm{g}$ ), mesmo assim ficando muito abaixo da faixa-limite de $300 \mathrm{ml} / \mathrm{g}$ recomendada para se evitar bulking.

De acordo com Erdincler \& Vesilind (2000), a desintegração do lodo lança no meio materiais poliméricos com alto peso molecular que podem agir como polieletrólitos promovendo a floculação do lodo. Isso pode explicar o fato do baixo valor de IVL mesmo com aumento da biomassa nos tanques de aeração.

Quanto a produção de lodo nos reatores durante a etapa teste, a figura 5.32 ilustra o comportamento para o reator A.

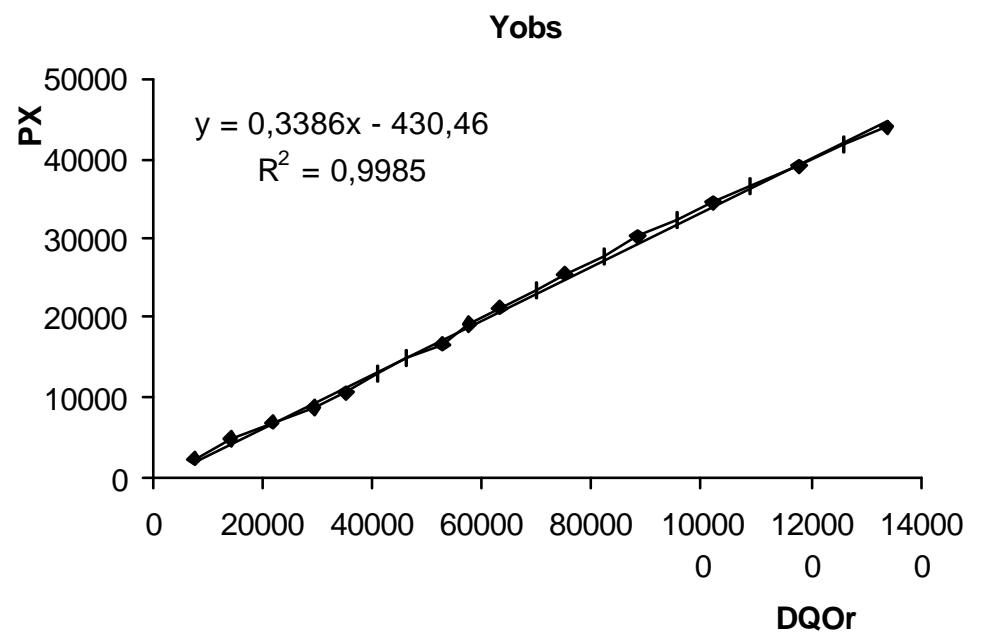

Figura 5. 32- Produção de lodo (Yobs) para o reator A - Etapa teste.

Nota-se que o valor de $\mathrm{Y}_{\mathrm{obs}}$ sofreu um pequeno acréscimo se comparado a etapa controle. Isso provavelmente deve-se ao fato de o reator ter recebido uma 
maior carga afluente devido a recirculação do lodo desintegrado. Entretanto deve-se lembrar que não houve em nenhum momento descarte de lodo do reator. Isso nos dá um $\mathrm{Y}_{\mathrm{obs}}$ teórico de zero, não levando em conta o teor de sólidos no efluente.

Quanto ao $\mathrm{Y}_{\mathrm{obs}}$ para o reator B, a figura 5.33 ilustra o comportamento.

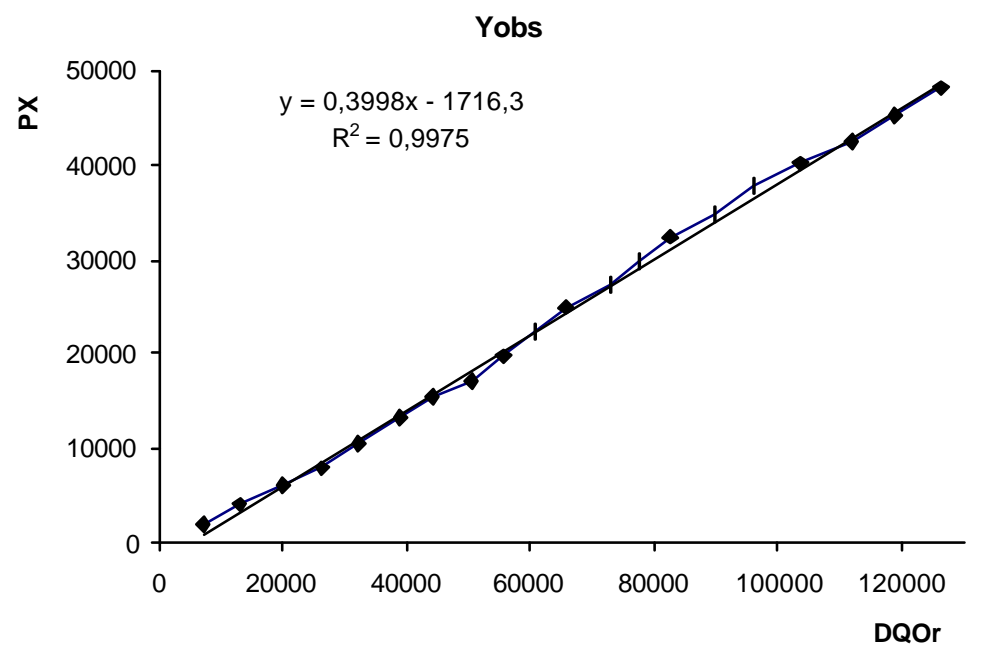

Figura 5. 33- Produção de lodo $\left(\mathrm{Y}_{\mathrm{obs}}\right)$ para o reator $\mathrm{B}$ - Etapa teste.

Já para o reator $\mathrm{B}$, houve um decréscimo (ainda que pequeno) no valor do $Y_{\text {obs }}$. Yasui \& Shibata (1994) estudaram a influência da ozonização no lodo em excesso de um sistema de lodos ativados e retorno do lodo ao tanque de aeração, onde foi observada um decréscimo no valor do $\mathrm{Y}_{\text {obs }}$. Os autores concluíram que o lodo ozonizado, transformado em alimento, e durante a degradação gerava em torno da metade da DBO em material mineralizado. Com isso a produção de lodo em excesso diminuía, como ilustrado na figura 5.34. Chen et al. (2000) citam que se $50 \%$ dos substratos eventualmente são convertidos em dióxido de carbono pela biooxidação, assim o excesso de lodo pode ser reduzido. 


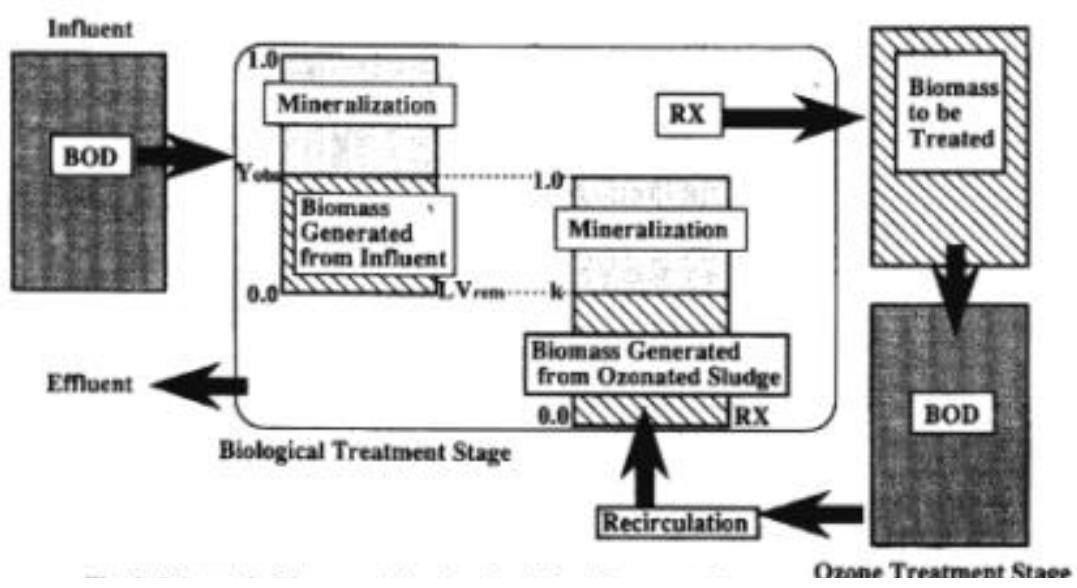

Figura 5. 34 - Diagrama do processo de tratamento com recirculação

Fonte : Yasui \& Shibata (1994)

Outra provável explicação é que o lodo produzido, além de a sua metade ser transformada em dióxido de carbono, vem desintegrado pelo ultra-som. Essa desintegração pode causar um craqueamento das substâncias transformando-as em outras substâncias com menor valor energético. Assim a energia obtida pela massa microbiana seria menor e portanto menor seria a produção de biomassa.

Outra consideração a fazer sobre a diminuição do lodo em excesso é devido ao fato que o retorno do lodo com substâncias altamente biodegradáveis, além de ser um lodo desintegrado do tipo "primário" (Já citado na revisão), podem causar um desbalanceamento nas equações de anabolismo e catabolismo. A energia obtida na quebra dos materiais presentes no afluente não é utilizada normalmente para aumento de biomassa (energy spilling). 
Bitton $^{1}$ apud Liu \& Tay (2001) comenta que a produção de biomassa está ligada diretamente a quantidade de energia produzida pelo catabolismo, entretanto existem evidências, sob determinadas condições como a presença de metais pesados, temperaturas anormais, ciclos alternados aeróbio-anaeróbio que causam dissociação entre o catabolismo e anabolismo. Liu \& Tay (2001) comentam ainda que do ponto de vista da engenharia ambiental o conceito de dissociação pode ser extendido para o fenômeno pelo qual a taxa de consumo de substrato é maior que a requerida para crescimento e manutenção. Como resultado, o crescimento da biomassa é reduzido sensivelmente.

Durante a aplicação do ultra-som no lodo podem ter ocorrido reações que produziram compostos químicos que pudessem atuar como dissociadores. Mayhew \& Stephenson (1998) estudaram adição de 2,4 Dinitrofenol como dissociador químico em um reator de lodo ativado e constataram que a produção de lodo diminuiu de $Y=0,42$ para $Y=0,30$. Liu (2000) cita que existe uma forte evidência no fato de que o aumento na relação concentração de substrato por biomassa ( $\mathrm{S} / \mathrm{X})$ possa ocasionar uma diminuição no valor de $\mathrm{Y}$. O autor comenta que o aumento desta esta relação possa atuar como dissociador.

O valor da relação $\mathrm{S} / \mathrm{X}$ para $\mathrm{o}$ reator $\mathrm{A}$ na fase controle foi de 0,32mgDQO/mgSSV, e na etapa teste foi de 0,26mgDQO/mgSSV. Para o reator B, o qual teve a sua produção de lodo reduzida durante a etapa teste, a relação foi de 0,26mgDQO/mgSSV na etapa controle, e de 0,34mgDQO/mgSSV na etapa teste, indo de encontro a afirmação de Liu (2000): maior S/X implicando em menor Y.

\footnotetext{
${ }^{1}$ Bitton, G. (1994). Wastewater Microbiology. Willey-liss, New York.
} 


\subsection{Nutrientes}

Quanto à remoção de nutrientes, foram feitos perfis temporais para se verificar o comportamento dos compostos nitrogenados verificando suas transformações até a nitrificação. Foram realizados alguns perfis para verificar o comportamento dos reatores quanto a nitrificação.

Passados 180 dias, observou-se que o reator A ainda não apresentava nitrificação. Decidiu-se não modificar as relações de nutrientes e começar a etapa teste para verificar se a mudança na relação de nutrientes afetaria a nitrificação.

\subsubsection{Etapa controle}

Para fins didáticos, só serão apresentados os resultados do último perfil de nitrogênio realizado na etapa teste onde é mostrado o comportamento do reator imediatamente antes a etapa teste. Os outros perfis se encontram em tabelas no anexo. A figura 5.35 ilustra o perfil realizado para o reator A.

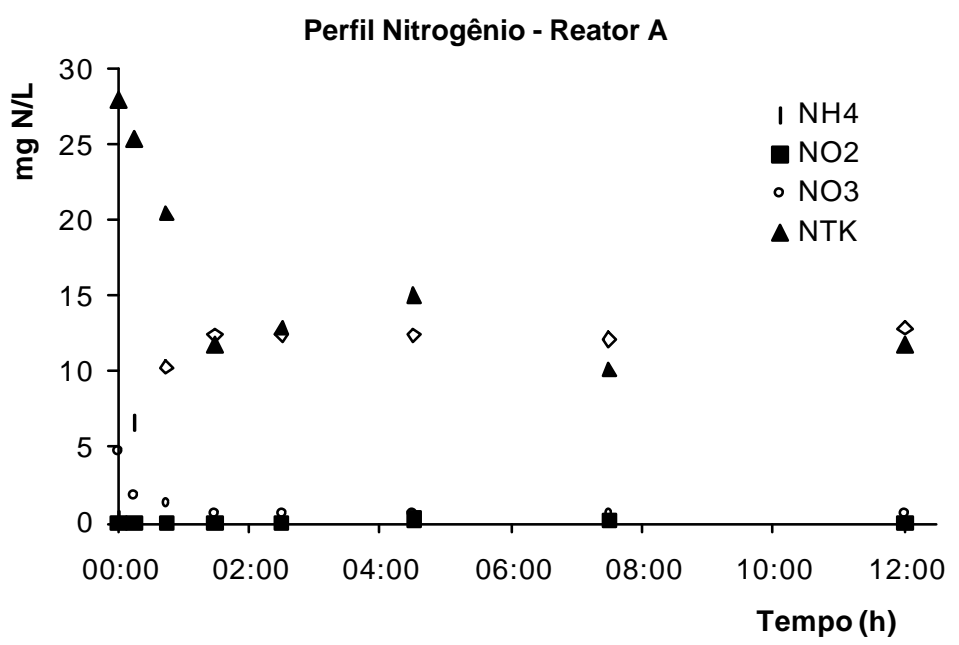

Figura 5. 35- Perfil temporal de compostos nitrogenados para o reator A - Etapa controle. 
Como se observou, o reator A não apresentou um bom perfil de nitrificação. Houve uma queda de aproximadamente $55 \%$ no teor de nitrogênio total, acompanhado de um incremento no teor de nitrogênio amoniacal, indicando assim um processo de amonificação do afluente. Entretanto a amonificação não foi completa, e também não houve uma significativa formação de nitrato. Interessante notar que o teor de nitrato decresceu com o tempo e houve uma remoção média de 63\% no teor de nitrogênio total (NTK, nitrito e nitrato), o que sugere uma desnitrificação aeróbia. Este fato também foi notado por Oliveira (2001) estudando relações de carbono e nitrogênio em um reator semelhante ao estudado

Casey et al. (1992) citam que, inicialmente a desnitrificação só era considerada. por via anóxica, ocorrendo na total ausência de oxigênio. Entretanto já existem demonstrações da desnitrificação aeróbia em culturas puras.

Já o reator $\mathrm{B}$, a figura 5.36 ilustra o comportamento dos compostos nitrogenados. $\mathrm{O}$ reator $\mathrm{B}$ apresentou uma melhora no processo de nitrificação: houve uma redução quase completa do teor de nitrogênio total, um aumento do teor de nitrogênio amoniacal e depois um decréscimo, sugerindo que a amônia se transformou em nitrito. O teor de nitrito sofreu um leve aumento e depois um decréscimo, sugerindo, assim, que tenha se transformado em nitrato. Já o teor de nitrato sofreu um acréscimo ao longo do tempo, entretanto não o suficiente para que todo o nitrogênio tenha se oxidado para essa forma. 


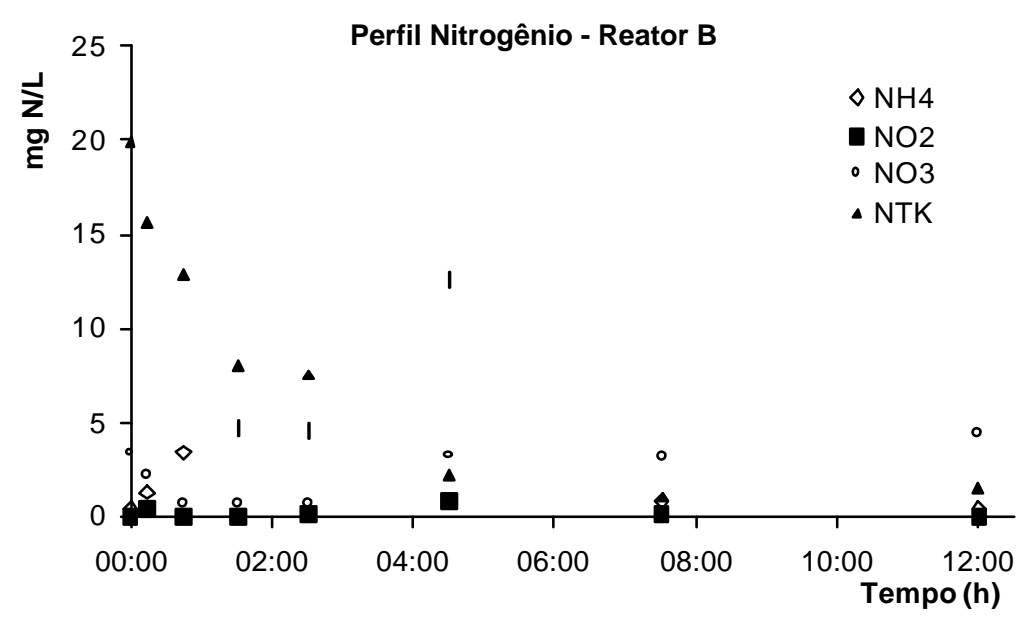

Figura 5. 36- Perfil temporal de compostos nitrogenados para o reator B - Etapa controle.

Acredita-se mais uma vez, que tenha havido algum tipo de desnitrificação aeróbia, visto que a remoção média foi de $67 \%$ para o reator B.

Apesar de a nitrificação não ser completa em ambos os reatores, optou-se por não fazer nenhuma mudança nos teores de nutrientes presentes no substrato sintético, acreditando que, com a lise, haveria um aumento nos nutrientes presentes no afluente, melhorando assim as relações carbono-nitrogênio-fósforo.

Com relação ao fósforo total, a figura 5.37 ilustra o comportamento.

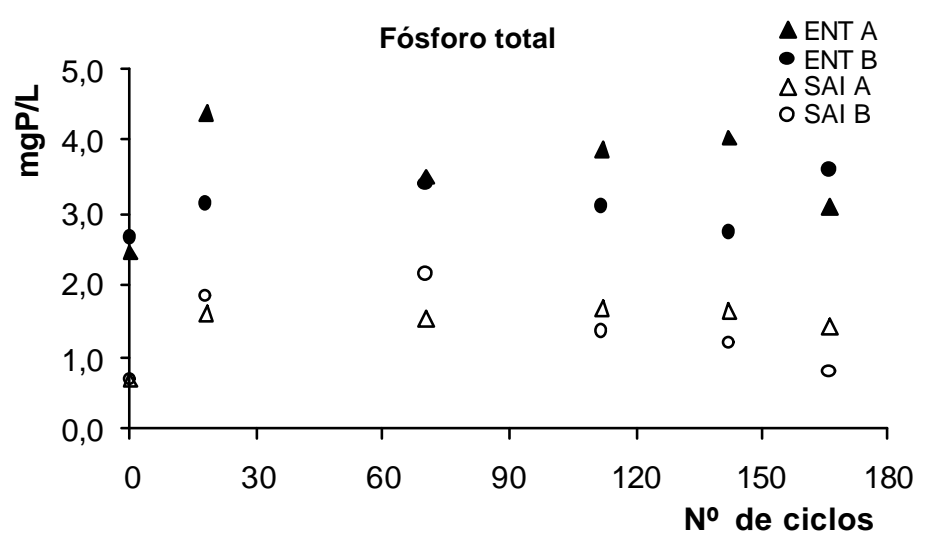

Figura 5. 37- Teor de fósforo total afluente e efluente dos reatores A e B - Etapa controle. 
Os reatores apresentaram comportamento semelhante no que diz respeito à remoção de fósforo total. A eficiência média de remoção para o reator A foi de $60 \%$, e para o reator B foi de 57\%, valores acima dos citados em literatura. Segundo Von Sperling (1996), a eficiência de remoção de fósforo varia entre 30 e 45\%, para sistemas convencionais, e entre 10 e $20 \%$ para sistemas com aeração prolongada.

\subsubsection{Etapa teste}

Durante a etapa teste, foram realizados perfis semanais dos nutrientes para verificar o comportamento dos mesmos quando da recirculação do lodo desintegrado. Para fins didáticos, só será colocado o último perfil de cada reator.

Com relação a remoção de nitrogênio total, a figura 5.38 fornece o comportamento ao longo da etapa teste para o reator A.

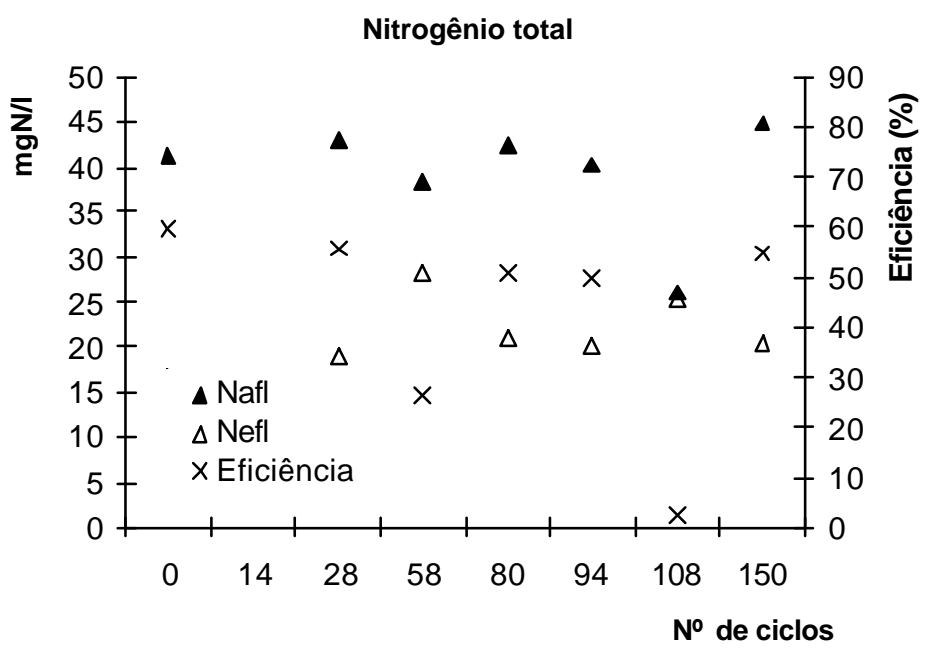

Figura 5. 38 - Eficiência de remoção de nitrogênio total no reator A - Etapa teste.

A eficiência de remoção do nitrogênio total situou-se em torno de $43 \%$ para o reator A, porém com quedas a praticamente zero de eficiência. Houve um 
decréscimo com relação a eficiência da etapa controle. Só tem sentido se falar em eficiência de remoção de nitrogênio total se o sistema for dotado de um ambiente anóxico para desnitrificação, seja na forma de zonas com deficiência de aeração ou mesmo zonas anóxicas no interior do floco. Mesmo que esses casos não tenham sido analisados nesse estudo, pode-se inferir que houve algum tipo de desnitrificação aeróbia no reator.

O mesmo vale para o reator $\mathrm{B}$, como ilustrado na figura 5.39. A eficiência de remoção do nitrogênio total se situou em torno de 55\%, menor que na etapa controle. A eficiência foi menor na etapa teste porque começaram a aparecer as formas de nitrogênio que normalmente aparecem em um sistema aeróbio: aumento de nitrato e decaimento de nitrogênio total.

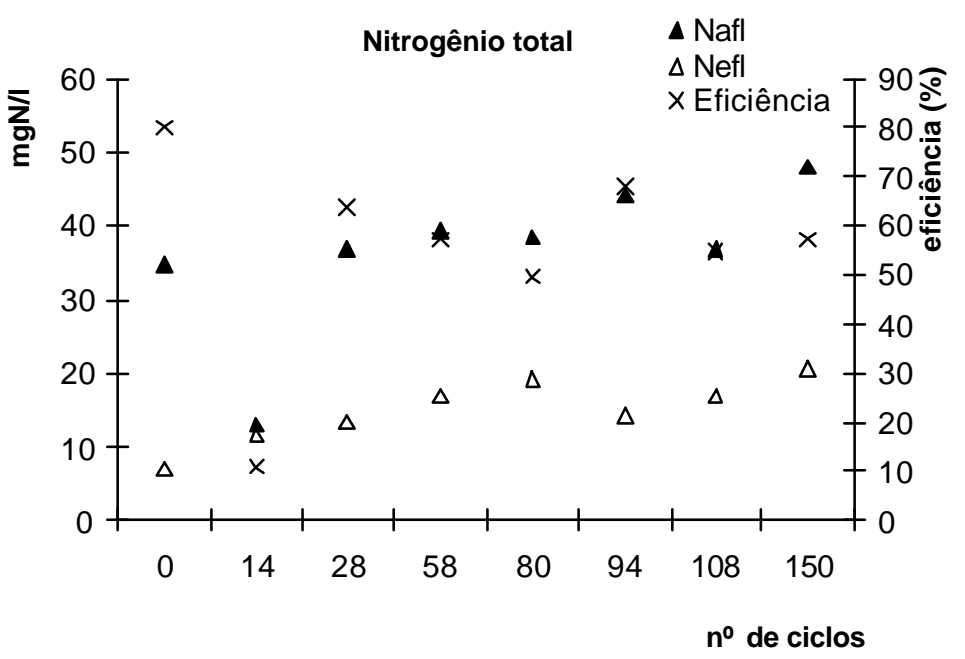

Figura 5. 39 - Eficiência de remoção de nitrogênio total para o reator B - Etapa teste

Para sistemas aeróbios a eficiência de remoção de nitrogênio total é muito baixa, visto que todas as formas de nitrogênio tendem a ir a nitrato e uma pequena parcela é utilizada para crescimento celular. 
Como foram vários perfis realizados na etapa teste, só será colocado aqui o perfil inicial e final de cada reator estudado. Assim se poderá visualizar o comportamento dos nutrientes com o decorrer do estudo.

Nesta etapa teste foram também efetuados perfis para fósforo total, como mostrados na figura 5.38 .

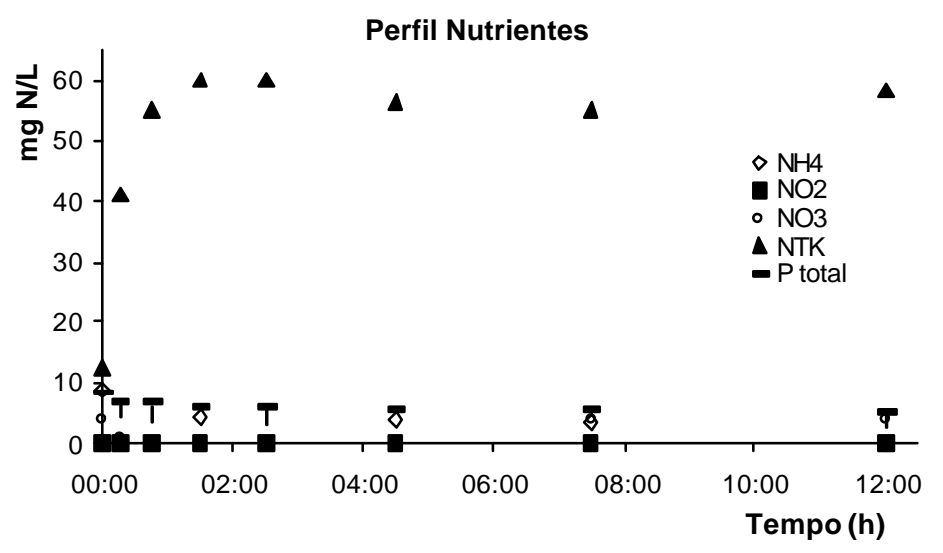

Figura 5. 40 - Perfil de nutrientes no início da etapa teste para o reator A.

No início da etapa teste, o reator A não apresentou um comportamento de nitrificação como demonstrado na figura 5.40. Notou-se que o teor de NTK aumentou e depois permaneceu constante. Isso pode ser devido ao acúmulo de nitrogênio orgânico proveniente da biomassa do lodo desintegrado. Entretanto já se pode notar um decréscimo no teor de nitrogênio amoniacal e um acréscimo no teor de nitrato indicando um processo, ainda que incompleto, de nitrificação.

Quanto a remoção de fósforo, houve uma queda na eficiência em relação a etapa controle. Nesta etapa, a eficiência de transferência foi de 35\% (contra $60 \%$ da etapa controle). Essa baixa na eficiência deve-se ao fato que o fósforo, ao contrário do nitrogênio que sai no efluente, fica retido na biomassa. Como o excesso de lodo é 
reciclado após ultra-som, há um retorno de fósforo ao afluente aumentando assim a concentração inicial. O decréscimo também pode ser explicado pela adaptação da biomassa as novas condições de carga afluente.

Quanto ao reator $\mathrm{B}$, o perfil de nutrientes no início da etapa teste é mostrado na figura 5.41.

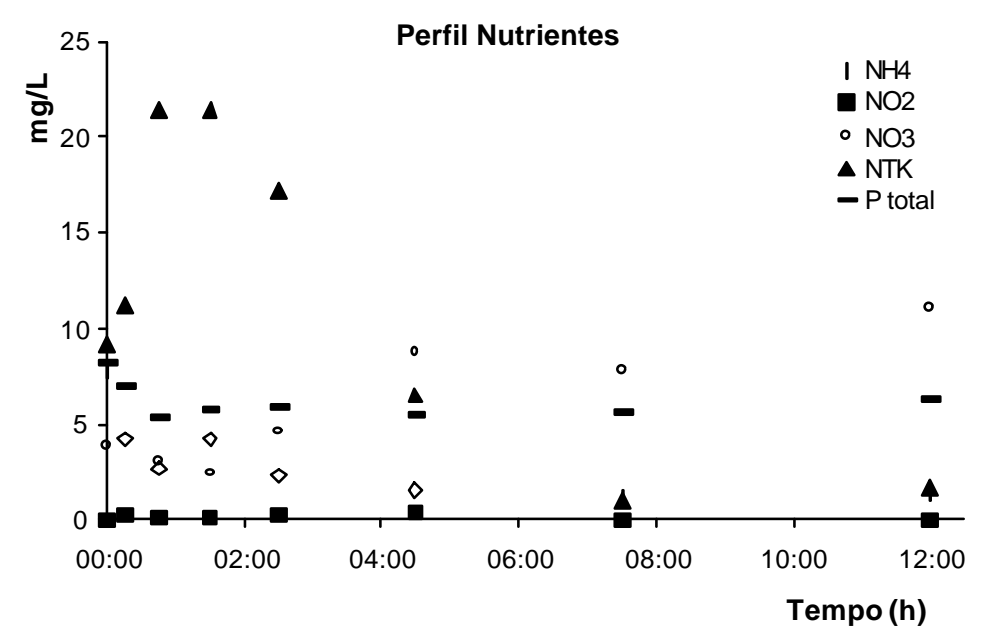

Figura 5. 41- Perfil de nutrientes no início da etapa teste para o reator B

No reator $\mathrm{B}$, a remoção de nitrogênio total foi mais acentuada que no reator A para o início da etapa teste. Notou-se um crescimento de NTK no início do perfil devido principalmente ao retorno de nitrogênio na forma orgânica presente no lodo retornado ao afluente. Entretanto o Nitrogênio total foi prontamente oxidado chegando a quase zero no fim do perfil. Notou-se também uma leve oscilação no teor de nitrogênio amoniacal. Inicialmente ele estava sendo transformado em nitrito e começou a decrescer. Entretanto o nitrogênio total estava sendo transformado em amoniacal e isso acarretou em um pequeno crescimento no teor de nitrogênio na forma amoniacal. Após a primeira hora do ciclo já se podia notar o decréscimo do 
nitrogênio amoniacal que estava sendo oxidado a nitrito. Notou-se também um leve aumento no teor de nitrito, entretanto ele foi logo oxidado a nitrato, forma mais oxidada possível.

Com relação ao teor de fósforo, o mesmo comportamento observado no reator A pode ser descrito para o reator B. Houve uma menor remoção em relação ao reator B da etapa controle $(22 \%$ de remoção na etapa teste contra $57 \%$ na etapa controle). Pode-se deduzir que a redução na remoção de fósforo deve-se ao aumento da quantidade de fósforo presente no afluente quando da adição do lodo desintegrado com o ultra-som. Após 8 perfis dos reatores A e B, chegou-se ao final da pesquisa com o reator A apresentando o comportamento ilustrado na figura 5.42.

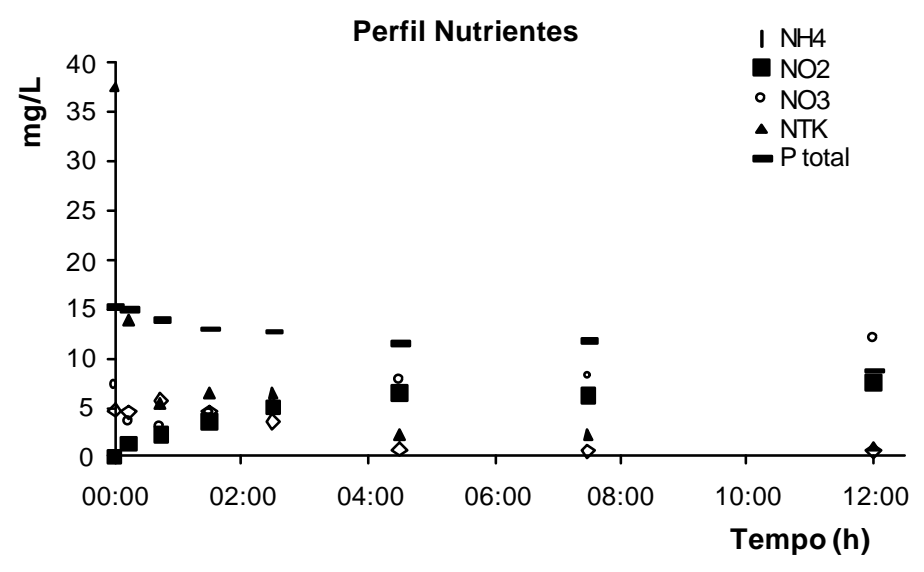

Figura 5. 42- Perfil de nutrientes no final da etapa teste para o reator A.

Como ilustrado na figura, notou-se que o reator A apresentou melhora em sua nitrificação. Já se podia notar uma maior diminuição no nitrogênio total e no nitrogênio amoniacal e um aumento no teor de nitrato. Mesmo assim a nitrificação não foi completa pois havia uma grande quantidade de nitrito presente. 
Com relação ao fósforo total, o reator continuava apresentando uma eficiência menor que na etapa controle, porém muito maior que no início da etapa teste: $42 \%$.

Para o reator $\mathrm{B}$, a figura 5.43 ilustra o comportamento dos nutrientes no final da pesquisa.

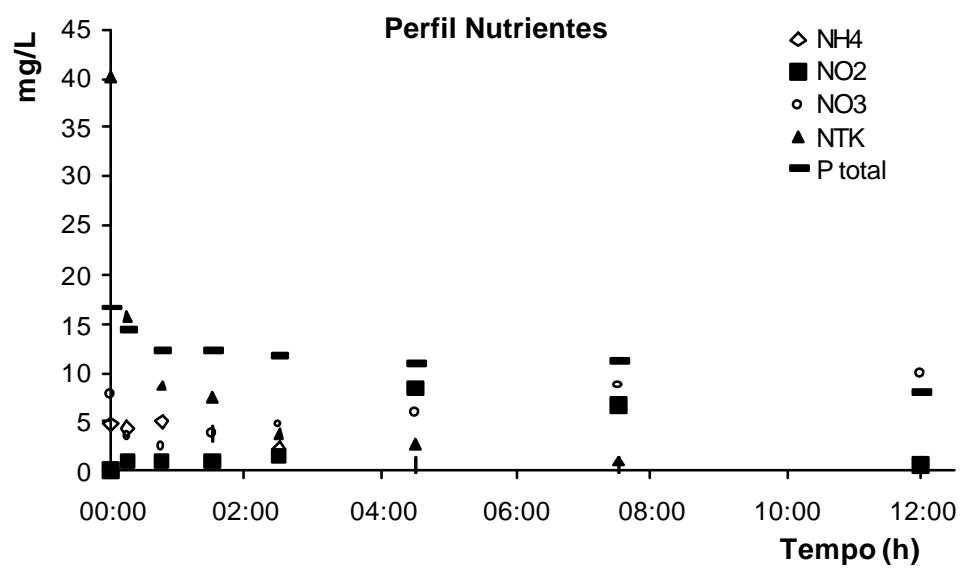

Figura 5. 43-Perfil de nutrientes no final da etapa teste para o reator B

Como ilustrado na figura 5.43, o reator B apresentou uma completa nitrificação. Verificou-se que todas as formas de nitrogênio foram para a sua forma mais oxidada: o nitrato. Apesar de o consumo da DQO ter sido praticamente completo nas primeiras três horas, o processo de nitrificação levou as doze horas do ciclo.

Com relação ao fósforo, o reator $\mathrm{B}$ continuou a apresentar uma menor eficiência de remoção com relação a etapa inicial. Mas apresentou uma melhora em sua eficiência se comparado a fase inicial da etapa teste: $44 \%$. 
As melhorias no processo de nitrificação para os dois reatores durante a etapa teste podem ser relacionadas com a diminuição da relação DQO/NTK. Esta relação para o reator $\mathrm{A}$, foi de $24,3 \mathrm{mgDQO} / \mathrm{mgN}$ para a etapa controle e de 21,1mgDQO/mgN para a etapa teste.Para o reator $\mathrm{B}$ a relação foi de $27,2 \mathrm{mgDQO} / \mathrm{mgN}$ para a etapa controle e $23,8 \mathrm{mgDQO} / \mathrm{mgN}$ para a etapa teste.

Esta diminuição na relação deve-se ao fato que a concentração de nitrogênio no lodo retornado foi, em proporção, maior que a quantidade de DQO retornada.

\subsection{Microbiologia}

Foram realizados exames microscópicos no lodo dos dois reatores 1 vez a cada mês e analisadas as frequiências dos microrganismos presentes na amostra de acordo com a tabela 5.3.

Tabela 5. 3 - Freqüência dos microrganismos na amostra

\begin{tabular}{ccc}
\hline Freqüência de aparecimento & Definição \\
\hline 0 & Rusente \\
+ & Raro ou pouco comum, ou algum \\
++ & Comum \\
+++ & Muito comum \\
++++ & Abundante \\
\hline
\end{tabular}

A figura 5.44 ilustra o ambiente microscópico presente nos reatores A e B. 


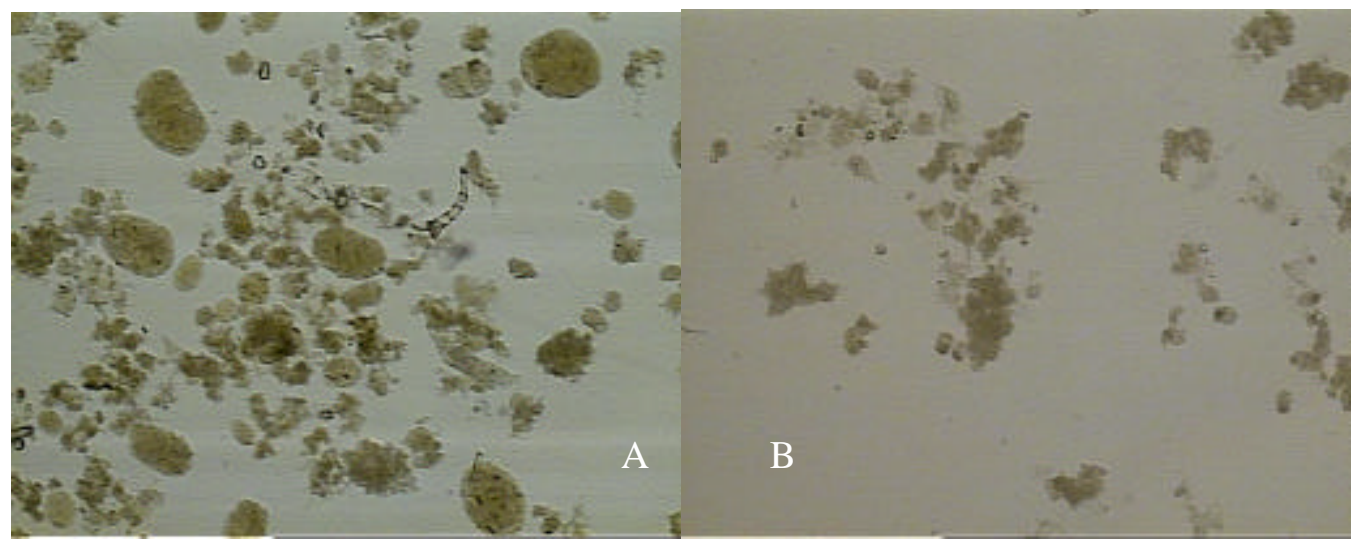

Figura 5. 44 - Microscopia dos lodos após 1 mês de aplicação do ultra-som. (40x)

$\mathrm{O}$ reator A apresentou um lodo com floco pequeno e disperso, presença de ácaros, rotíferos $(+++)$, ciliados livres(+), rastejantes $(+)$ uma pequena quantidade de bactérias filamentosas (+). A microfauna do reator A não apresentava uma grande variedade de microrganismos, característico de um lodo estabilizado.

$\mathrm{O}$ reator $\mathrm{B}$ já apresentava uma maior variedade de microrganismos. $\mathrm{O}$ floco se apresentava pequeno, mas menos disperso que o reator A (apesar de a figura 44 não fazer justiça). Foi notada a presença de rotíferos (+++), flagelados (++), ciliados rastejantes (+++), fixos (+), livres (+) e filamentosas $(++)$.

Após dois meses foi realizado outro exame microscópico ilustrado na figura 45. Após dois meses de aplicação do ultra-som, notou-se uma melhora na microfauna do lodo do reator A. O floco era pequeno e aberto e apresentava uma grande quantidade de rotíferos (++++). Apresentava também ciliados fixos (+), rastejantes $(++)$, ameba $(++)$, presença de cistos $(++)$ e filamentos $(+)$, e grande quantidade de bactérias em suspensão (++). 


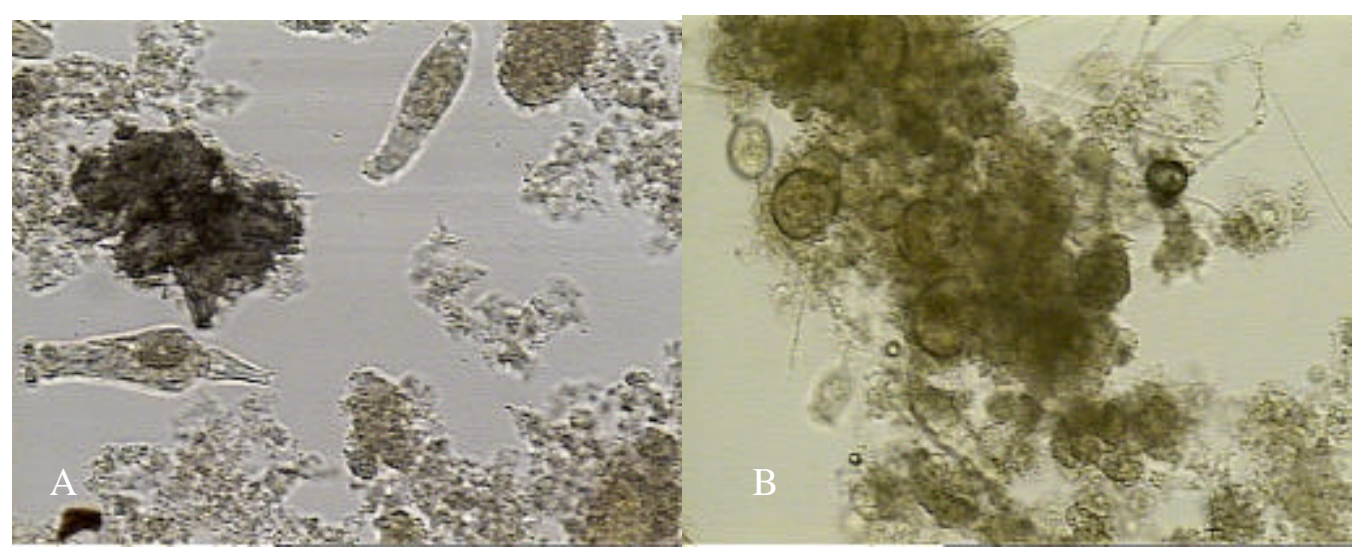

Figura 5. 45 - Microscopia dos lodos após 2 meses de aplicação do ultra-som. (100x)

No reator B foi observada a presença de ciliados rastejantes $(++++)$, fixos $(++)$ e livres (+), um aumento na quantidade de bactérias filamentosas (++), flagelados(+), ameba (+).

No terceiro mês de aplicação de ultra-som foi realizada outra análise microscópica como mostrado na figura 5.46.

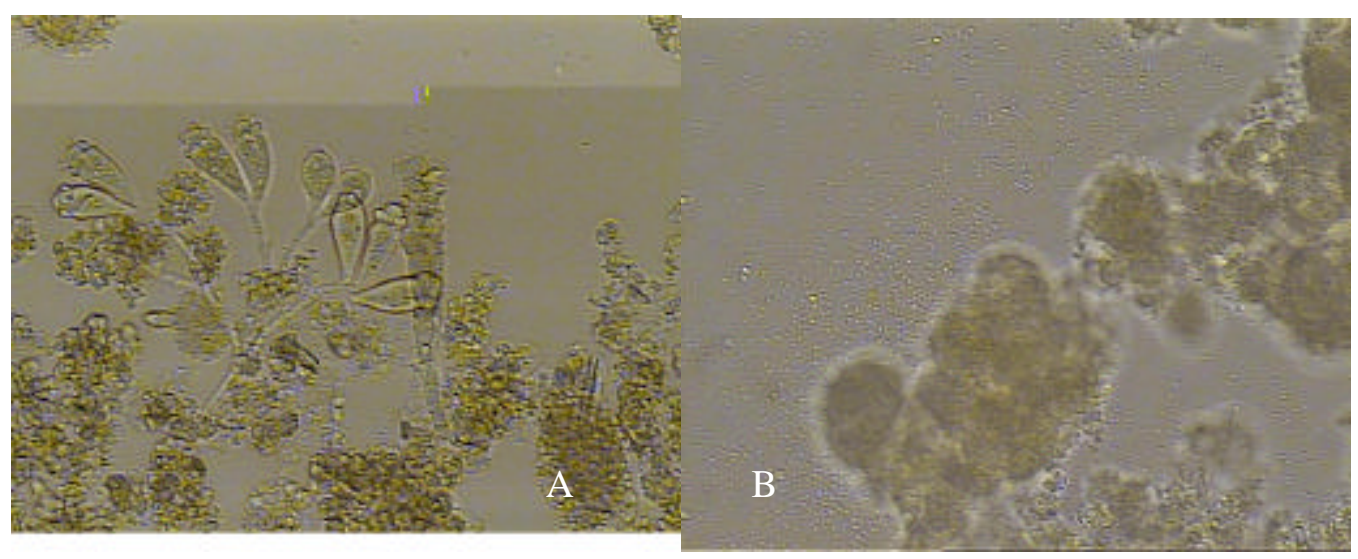

Figura 5. 46 - Microscopia dos lodos após 3 meses de aplicação do ultra-som. (100x)

O reator A apresentava um floco menos disperso que nas análises anteriores. Havia a presença de rotíferos (++), ciliados fixos (+++), rastejantes (+1+), flagelados (++), filamentos (+) e bactéria s em suspensão (+). 
No lodo do reator $\mathrm{B}$, o floco apresentava-se mais compacto. Havia a presença de ciliados fixos $(++)$, rastejantes $(+)$, livres. Apresentava também uma grande quantidade de filamentosas $(+++)$, presença de ameba(+) e bactérias em suspensão.

Com relação ao Número Mais Provável (NMP) de bactérias nitrificantes, também foram realizadas análises nos reatores A e B nas etapas controle e teste. Como se trata de uma análise bastante demorada (cerca de 1 mês), só foi realizada uma análise para a etapa controle e uma análise para a etapa teste, sempre ao final de cada etapa.

\subsubsection{Etapa controle}

Para a etapa controle, o NMP do reator A para as bactérias oxidadoras de amônia foi de $8,3 \times 10^{3} \mathrm{NMP} / \mathrm{gSSV}$, e para as bactérias oxidadoras de nitrito foi de 2,3x10 $0^{4} \mathrm{NMP} / \mathrm{gSSV}$. Para o reator B, o NMP para as bactérias oxidadoras de amônia foi de 2,2x10 ${ }^{6} \mathrm{NMP} / \mathrm{gSSV}$, e para as bactérias oxidadoras de nitrito foi de $1,1 \times 10^{5} \mathrm{NMP} / \mathrm{gSSV}$. Mendonça et al. (2001), estudando a atividade bacteriana em um reator aeróbio seqüencial em batelada, obtiveram valores de $1,3 \times 10^{9} \mathrm{NMP} / \mathrm{gSSV}$ para

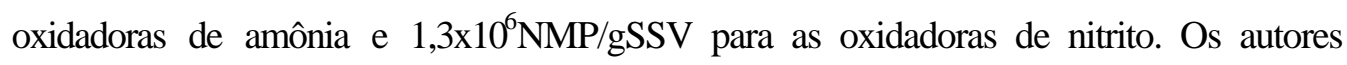
ainda cometam que houve uma boa eficiência na nitrificação. $O$ Baixo valor encontrado nesta pesquisa, com relação aos resultados descritos pelos autores acima, podem explicar o fato de que não houve nitrificação no reator A e pouca nitrificação no reator $\mathrm{B}$. 
Os resultados encontrados para NMP de bactérias nitrificantes são muito variados. Araki et al. (1999) $)^{2}$ apud Mendonça et. al (2001) estudando um reator de pós-tratamento de reatores UASB, quantificaram a população nitrificante na ordem de $10^{3}$ a $10^{4} \mathrm{NMP} / \mathrm{ml}$.

5.6.2 Etapa teste

$\mathrm{Na}$ etapa teste foi notada uma diminuição dos valores de NMP dos organismos nitrificantes, com exceção do NMP para as oxidadoras de amônia no reator A.

Para o reator A o NMP das bactérias oxidadoras de amônia foi de 2,5x10 $\mathrm{NMP} / \mathrm{gSSV}$, e o NMP para as oxidadoras de nitrito foi de 5,9x10 ${ }^{3} \mathrm{NMP} / \mathrm{gSSV}$. Para o reator B o NMP das bactérias oxidadoras de amônia foi de $2,5 \times 10^{4} \mathrm{NMP} / \mathrm{gSSV}$, e o NMP para as oxidadoras de nitrito foi de $3,6 \times 10^{4} \mathrm{NMP} / \mathrm{gSSV}$.

Apesar da diminuição do NMP na etapa teste, foi notada uma melhora no processo de nitrificação em ambos os reatores. Com isso foram cogitadas algumas possibilidades:

1. A aplicação do ultra-som pode ter selecionado algum microrganismo predador das bactérias nitrificantes;

2. A aplicação do ultra-som pode ter gerado algum composto tóxico para as bactérias nitrificantes;

\footnotetext{
${ }^{2}$ Araki, N.; Ohashi, A.; Machdar, I.; Harada H. (1999). Behaviors of Nitrifiers in a Novel Biofilm Reactor Employing Hanging Sponge-Cubes as Attachment Site. Wat. Sci. Tech., v. 39, n. 7, pp. 2331.
} 
3. A nitrificação melhorou por causa da melhora da relação DQO/NTK, apesar da diminuição do NMP das bactérias;

4. Erro na análise de NMP.

\subsection{Consumo de oxigênio}

A seguir serão mostrados os valores encontrados nos perfis respirométricos durante as etapas controle e teste. Como já citado anteriormente, foi realizado um ensaio em batelada do reator em batelada. Com isso podia se verificar o comportamento da taxa de consumo de oxigênio (TCO) ao longo do tempo e verificar a sua variação nas etapas controle e teste dos dois reatores. A figura 5.47 ilustra o comportamento do oxigênio dissolvido durante o ensaio de TCO.

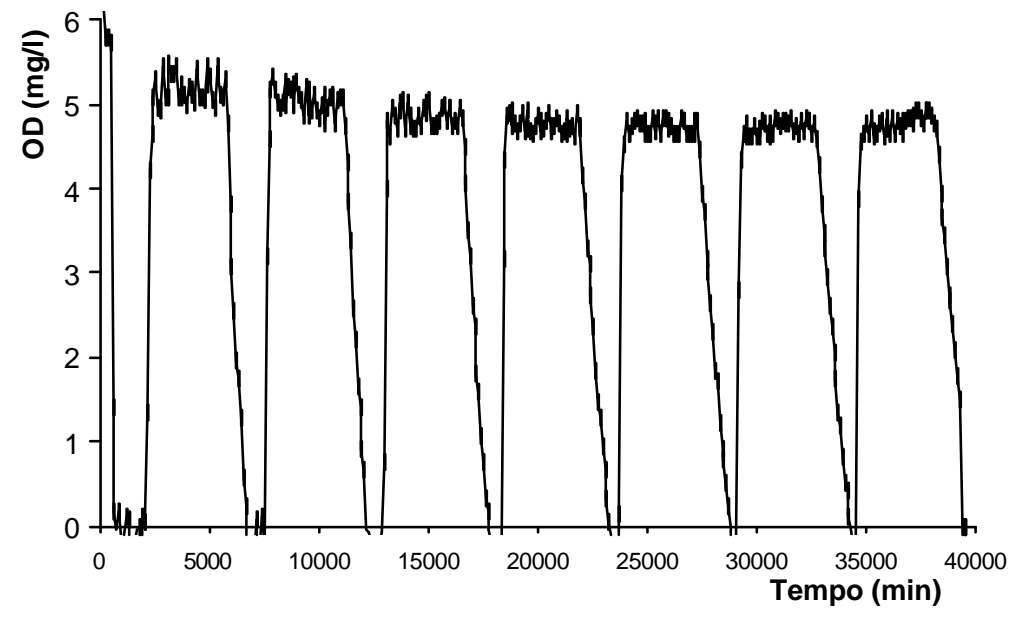

Figura 5. 47 - Ensaio para verificação da TCO ao longo de um ciclo.

Após a elaboração do gráfico, foi medido o decaimento do oxigênio dissolvido em todas as vezes que era parada a aeração no interior do erlenmeyer 
utilizado para os ensaios. Com isso se achava o valor da taxa de consumo ao longo do tempo.

\subsubsection{Etapa controle}

O perfil respirométrico para o reator A está ilustrado na figura 5.48.

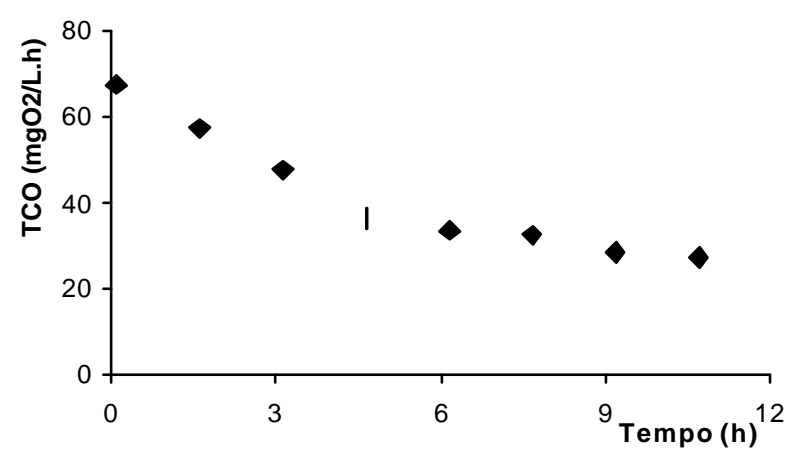

Figura 5. 48 - Perfil respirométrico para o reator A - Etapa controle.

Como pode ser notado, a taxa de consumo de oxigênio variou com o tempo do ciclo. O consumo de oxigênio, dado pela área abaixo da curva, foi de 429,6 $\mathrm{mgO}_{2} /$ L.A taxa média de consumo de oxigênio, utilizada neste estudo para o balanço de massa, foi de $39,1 \mathrm{mgO}_{2} /$ L.h. A taxa média foi calculada como sendo a razão entre a área e o tempo do experimento.

Van Haandel e Marais (1999) comentam que o valor da TCO, na maioria dos sistemas de lodos ativados, está situado entre 30 a $100 \mathrm{mgO}_{2} / \mathrm{L} . \mathrm{h}$, entretanto esses valores devem estar relacionados com reatores contínuos ou não utilizem de uma taxa média de TCO. 
Com relação a taxa de consumo de oxigênio para o reator Bna etapa teste, a figura 5.49 ilustra o comportamento.

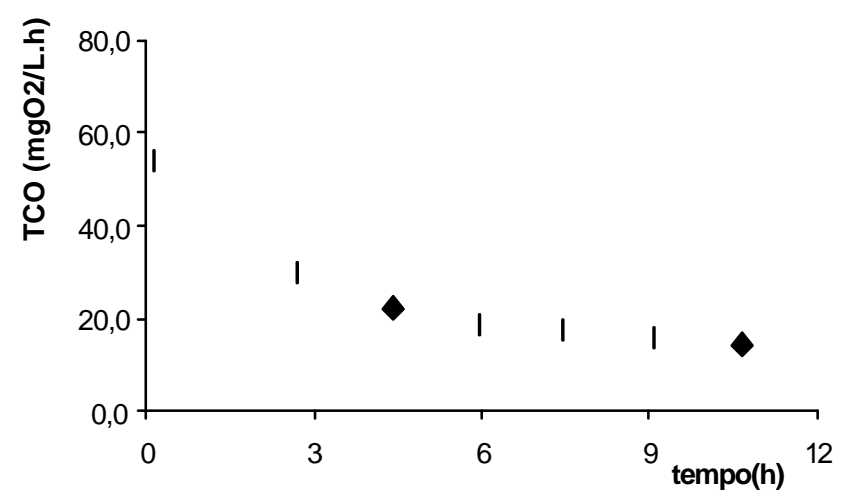

Figura 5. 49- Perfil respirométrico para o reator B - Etapa controle.

$\mathrm{O}$ reator $\mathrm{B}$ apresentou um consumo de oxigênio de $260,8 \mathrm{mgO}_{2} / \mathrm{L}$. Esse valor é menor que o do reator A para a etapa controle, provavelmente devido a menor idade do lodo do reator B. A taxa média de consumo de oxigênio se situou em 23,7mgO 2 L.h.

Pelos perfis respirométricos ilustrados dá para ter uma idéia do consumo ao longo do tempo e projetar o sistema para variar a vazão de ar introduzida de acordo com a necessidade do reator, otimizando o sistema.

\subsubsection{Etapa teste}

Para a etapa teste também foram realizados perfis respirométricos. A figura 5.50 ilustra o perfil para o reator A. 


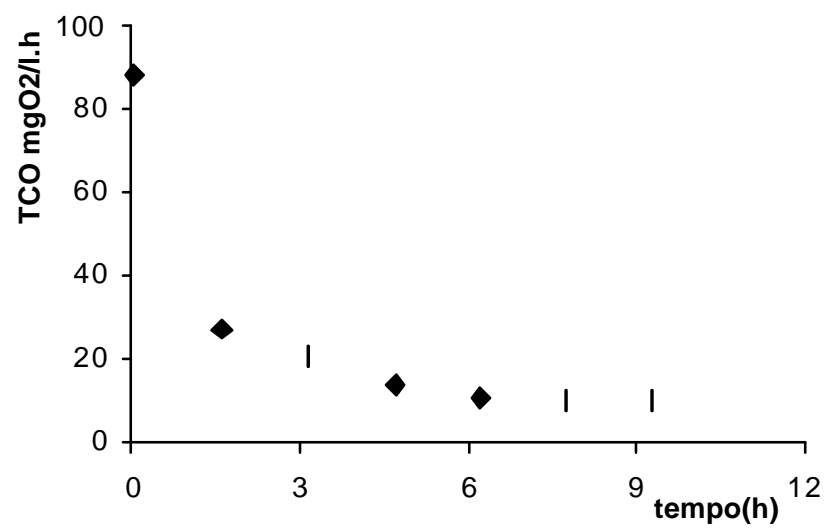

Figura 5. 50 - Perfil respirométrico para o reator A - Etapa teste.

Pode-se notar o aumento na taxa de consumo inicial nesta etapa teste. A TCO inicial para o reator A na etapa controle foi de $67,2 \mathrm{mgO}_{2} / \mathrm{L}$.h, e para a etapa teste foi de $88,2 \mathrm{mgO}_{2} /$ L.h. Entretanto a taxa cai rapidamente com o decorrer do tempo de operação, provavelmente devido ao retorno de substâncias altamente biodegradáveis presentes no lodo desintegrado e que auxiliaram na degradação aeróbia. Este fato é corroborado pela diminuição da taxa média de consumo,que se situou em $18,3 \mathrm{mgO}_{2} / \mathrm{L}$.h, e o consumo total, que se situou em torno de $201,6 \mathrm{mgO}_{2} / \mathrm{L}$. Isto significa que, mesmo com o aumento da carga, o consumo de oxigênio diminuiu, evidenciando que o lodo desintegrado atuou como uma espécie de catalisador acelerando a reação de degradação.

O mesmo fato foi notado para o reator B, ilustrado pela figura 5.51. 


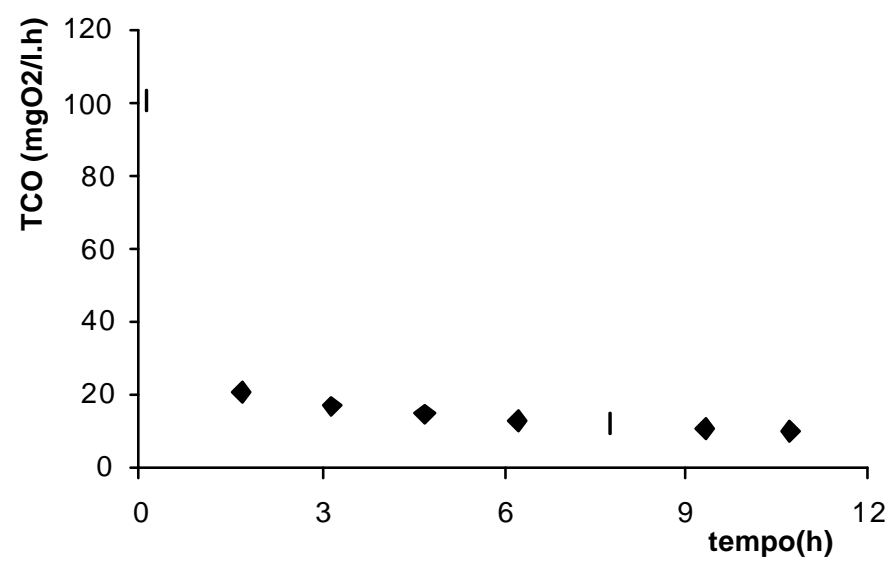

Figura 5. 51 - Perfil respirométrico para o reator B - Etapa teste.

$\mathrm{O}$ reator $\mathrm{B}$ também apresentou um taxa de consumo de oxigênio alta no início do experimento $\left(100,6 \mathrm{mgO}_{2} / \mathrm{L} \cdot \mathrm{h}\right)$ se comparado a etapa controle (56,0 $\mathrm{mgO}_{2} /$ L.h $)$, devido ao aumento da caga inicial. Entretanto o consumo total sofreu um decréscimo para $219,7 \mathrm{mgO}_{2} / \mathrm{L}$, e a taxa média de consumo caiu para cerca de $20,1 \mathrm{mgO}_{2} /$ L.h.

Nota-se ainda que o valor da TCO residual para o reator A também sofreu um decréscimo, indo de $27,1 \mathrm{mgO}_{2} / \mathrm{L} . \mathrm{h}$ para $9,9 \mathrm{mgO}_{2} / \mathrm{L}$.h. Isto indica que ainda existia atividade dentro do reator, na etapa teste, além da respiração endógena. Possivelmente poderia estar ocorrendo uma desnitrificação aeróbia, já que a matéria carbonácea foi praticamente consumida dentro das 3 primeiras horas do ciclo.

O mesmo pode ser notado para o reator B. A TCO residual foi de $14,0 \mathrm{mgO} / 2$ L.h para a etapa controle e de $10,1 \mathrm{mgO}_{2} / \mathrm{L}$.h para a etapa teste. 


\subsection{Balanços de massa}

Para se efetuar o balanço de massa para a matéria carbonácea e nitrogenada, se fez necessário a inclusão de algumas considerações:

1. A massa de oxigênio consumida para a nitrificação não foi calculada segundo a formação de nitrato e sim pela diferença das concentrações de NTK afluente e efluente, visto que não foram encontrado valores de nitrato, principalmente na etapa controle, correspondentes ao decaimento do NTK;

2. O valor da Razão DQO/SSV (fcv) foi calculado a partir dos valores encontrados na etapa teste para cada reator (lodo retornado e sua respectiva DQO). Assim não foi utilizado o valor usual da literatura que é de $1,48 \mathrm{mg}$ DQO/mg SSV;

3. Foi utilizado a TCO média dos respectivos reatores em suas respectivas etapas;

4. Os resultados são dados por ciclo de operação e não por dia.

\subsubsection{Etapa controle}

Os dados de entrada para o balanço de massa do reator A encontram-se na tabela 5.4 
Tabela 5. 4 - Dados de entrada para o balanço de massa do reator A - Etapa controle.

\begin{tabular}{|c|c|c|c|}
\hline Parâmetros & $\begin{array}{c}\text { Dados de } \\
\text { entrada }\end{array}$ & Nomenclatura & unidade \\
\hline $\mathrm{Q}$ & 9,5 & Vazão afluente & 1/ciclo \\
\hline $\mathrm{q}$ & 0,625 & Vazão de lodo & 1/ciclo \\
\hline Sta & 574 & DQO afluente & $\mathrm{mg} / \mathrm{l}$ \\
\hline Ste & 50 & DQO efluente & $\mathrm{mg} / \mathrm{l}$ \\
\hline$f c v$ & 0,97 & Razão DQO/SSV & $\mathrm{mg} \mathrm{DQO} / \mathrm{mg} \mathrm{SSV}$ \\
\hline $\mathrm{Xv}$ & 1792,0 & SSV no tanque & $\mathrm{mgSSV} / \mathrm{l}$ \\
\hline Ot & 39,11 & Taxa de Utilização de oxigênio & $\mathrm{mgO}_{2} / \mathrm{lh}$ \\
\hline $\mathrm{Vr}$ & 15 & Volume do reator & 1 \\
\hline Ntka & 25,79 & Nitrogênio total Kjeldahl afluente & $\mathrm{mgN} / \mathrm{l}$ \\
\hline Ntke & 9,13 & Nitrogênio total efluente & $\mathrm{mgN} / \mathrm{l}$ \\
\hline Nna & 4,22 & Nitrato no alfuente & $\mathrm{mgN} / \mathrm{l}$ \\
\hline Nne & 0,67 & Nitrato no efluente & $\mathrm{mgN} / \mathrm{l}$ \\
\hline fn & 0,1 & fração de Nitrogênio no lodo & $\mathrm{mgN} / \mathrm{l}$ \\
\hline
\end{tabular}

Com os dados da tabela 5.4 calcula-se o balanço de massa para DQO e

nitrogênio no reator A de acordo com as equações (4.7) a (4.19).

$\underline{\text { Balanço de DQO }}$

Massa de DQO efluente
Mdqoe=Q.Ste
$475 \mathrm{mgDQO} /$ ciclo

Massa de DQO no lodo
$\mathrm{Mdqol}=\mathrm{q} \cdot \mathrm{Xv} \cdot \mathrm{fcv}=$
1086mgDQO/ciclo

Massa de oxigênio para nitrificação

$$
\text { Mon=Q.(Ntka-Ntke).4,57= 723mgO2/ciclo }
$$

Massa de DQO oxidada

$$
\text { Mdqoox=Ot.Vr.12-Mon= 6317mgDQO/ciclo }
$$

DQO de saída

$$
\text { DQOs=Mdqoe }+ \text { Mdqol+Mdqoox }=\quad \text { 7847mgDQO/ciclo }
$$


DQO de entrada

DQOe=Q.Sta $=\quad 5453 \mathrm{mgDQO} /$ ciclo

Relação de DQO \%

$\% \mathrm{DQO}=(\mathrm{DQOs} / \mathrm{DQOe}) .100 \quad 144 \%$

Balanço de Nitrogênio

Massa de Nitrato no efluente

MNne=Q.Nne=

$6 \mathrm{mgN} /$ ciclo

Massa de nitrato no afluente

$\mathrm{MNna}=\mathrm{Q} \cdot \mathrm{Nna}=$

40mgN/ciclo

Massa de NTK no efluente

MNte=Q.Ntke=

81mgN/ciclo

Massa de Nitrogênio no lodo

$$
\mathrm{MNl}=\mathrm{q} \cdot \mathrm{Xv} \cdot \mathrm{fn}=
$$

$112 \mathrm{mgN} /$ ciclo

Massa de nitrogênio na saída

MNs=Mne+Mntke+Mnl=

199mgN/ciclo

Massa de Nitrogênio na entrada

$\mathrm{MNe}=\mathrm{Q} \cdot \mathrm{Ntka}+\mathrm{MNna}=$

$285 \mathrm{mgN} /$ ciclo

Relação de Nitrogênio (\%)

$\% \mathrm{~N}=(\mathrm{MNs} / \mathrm{MNe}) \cdot 100=$

$70 \%$

Os balanços não conseguiram ser fechados, mas dão uma idéia das frações correspondentes de DQO e nitrogênio em cada entrada e saída do reator. Um motivo do não fechamento dos balanços é o baixo consumo de oxigênio pra nitrificação. 
Valor baixo deu origem a um alto valor de consumo de oxigênio devido a oxidação da matéria carbonácea, o que gera um maior valor na DQO de saída que de entrada, gerando o desbalancemento. $\mathrm{O}$ mesmo ocorre com o balanço de nitrogênio, onde a massa de saída por nitrificação foi pequena em relação a massa de entrada de NTK, sugerindo, mais uma vez, algum processo de desnitrificação.

Os dados de entrada para o reator B estão na tabela 5.5

Tabela 5. 5 - Dados de entrada para o balanço de massa do reator B - Etapa controle.

\begin{tabular}{cccc}
\hline Parâmetros & $\begin{array}{c}\text { Dados de } \\
\text { entrada }\end{array}$ & Nomenclatura & unidade \\
\hline $\mathrm{Q}$ & 9,5 & Vazão afluente & $1 /$ ciclo \\
$\mathrm{q}$ & 0,935 & Vazão de lodo & $1 /$ ciclo \\
$\mathrm{Sta}$ & 541 & DQO afluente & $\mathrm{mg} / \mathrm{l}$ \\
$\mathrm{Ste}$ & 64 & DQO efluente & $\mathrm{mg} / \mathrm{l}$ \\
$\mathrm{fcv}$ & 1,17 & Razão DQO/SSV & $\mathrm{mg} \mathrm{DQO} / \mathrm{mg} \mathrm{SSV}$ \\
$\mathrm{Xv}$ & 1841,0 & SSV no tanque & $\mathrm{mgSSV} / \mathrm{l}$ \\
$\mathrm{Ot}$ & 23,75 & Taxa de Utilização de oxigênio & $\mathrm{mgO} 2 / \mathrm{l} . \mathrm{h}$ \\
$\mathrm{Vr}$ & 15 & Volume do reator & 1 \\
$\mathrm{Nta}$ & 19,88 & Nitrogênio total afluente & $\mathrm{mgN} / \mathrm{l}$ \\
$\mathrm{Ntke}$ & 4,3 & Nitrogênio total efluente & $\mathrm{mgN} / \mathrm{l}$ \\
$\mathrm{Nna}$ & 4,22 & Nitrato no alfuente & $\mathrm{mgN} / \mathrm{l}$ \\
$\mathrm{Nne}$ & 3,94 & Nitrato no efluente & $\mathrm{mgN} / \mathrm{l}$ \\
$\mathrm{fn}$ & 0,1 & fração de Nitrogênio no lodo & $\mathrm{mgN} / \mathrm{l}$ \\
\hline
\end{tabular}

Para o reator B, os balanços foram os seguintes:

Massa de DQO oxidada

Mdqoox=Ot.Vr.12-Mon=

$3599 \mathrm{mgDQO} /$ ciclo

DQO de saída

$$
\text { DQOs=Mdqoe+Mdqol+Mdqoox }=\quad 6221 \mathrm{mgDQO} / \text { ciclo }
$$

DQO de entrada

$$
\text { DQOe=Q.Sta= }
$$

Relação de DQO \%

$$
\% \mathrm{DQO}=(\mathrm{DQOs} / \mathrm{DQOe}) .100 \quad 121 \%
$$


$\underline{\text { Balanço de Nitrogênio }}$

Massa de Nitrato no efluente
$\mathrm{MNne}=\mathrm{Q} \cdot \mathrm{Nne}=$
$37 \mathrm{mgN} /$ ciclo

Massa de nitrato no afluente
$\mathrm{MNna}=\mathrm{Q} \cdot \mathrm{Nna}=$
$40 \mathrm{mgN} /$ ciclo

Massa de NTK no efluente

$$
\text { MNte=Q.Ntke= }
$$

$41 \mathrm{mgN} /$ ciclo

Massa de Nitrogênio no lodo

$$
\mathrm{MNl}=\mathrm{q} \cdot \mathrm{Xv} \cdot \mathrm{fn}=
$$

Massa de nitrogênio na saída

$$
\mathrm{MNs}=\mathrm{Mne}+\mathrm{Mntke}+\mathrm{Mnl}=
$$

$$
250 \mathrm{mgN} / \text { ciclo }
$$

Massa de Nitrogênio na entrada

$$
\mathrm{MNe}=\mathrm{Q} \cdot \mathrm{Ntka}+\mathrm{MNna}=
$$

$$
229 \mathrm{mgN} / \text { ciclo }
$$

Relação de Nitrogênio (\%)

$\% \mathrm{~N}=(\mathrm{MNs} / \mathrm{MNe}) \cdot 100=$

$109 \%$

O mesmo caso ocorreu para o reator B no que diz respeito a DQO de saída ser maior que de entrada devido ao baixo valor de oxigênio devido a nitrificação.

Entretanto pode-se notar um melhor valor para os dois balanços devido a uma melhor nitrificação do reator $\mathrm{B}$ em relação ao A para a etapa controle. 


\subsubsection{Etapa teste}

Para os balanços de DQO e nitrogênio para a etapa teste, não foi considerado

o reciclo, pois assim só teriam valores de entrada e saída, já que o lodo era reciclado.

Considerou-se o aumento do lodo devido ao reciclo e o descarte, para se ter uma

idéia das formas de DQO e nitrogênio presentes.

Os dados de entrada para o reator A estão na tabela 5.6

Tabela 5. 6 - Dados de entrada para o balanço de massa do reator A - Etapa teste.

\begin{tabular}{cccc}
\hline Parâmetros & $\begin{array}{c}\text { Dados de } \\
\text { entrada }\end{array}$ & Nomenclatura & unidade \\
\hline $\mathrm{Q}$ & 9,5 & Vazão afluente & $\mathrm{l} /$ ciclo \\
$\mathrm{q}$ & 0,625 & Vazão de lodo & $\mathrm{1} / \mathrm{ciclo}$ \\
$\mathrm{Sta}$ & 749 & DQO afluente & $\mathrm{mg} / \mathrm{l}$ \\
$\mathrm{Ste}$ & 60 & DQO efluente & $\mathrm{mg} / \mathrm{l}$ \\
$\mathrm{fcv}$ & 0,97 & Razão DQO/SSV & $\mathrm{mg} \mathrm{DQO} / \mathrm{mg} \mathrm{SSV}$ \\
$\mathrm{Xv}$ & 2845,0 & SSV no tanque & $\mathrm{mgSSV} / \mathrm{l}$ \\
$\mathrm{Ot}$ & 18,36 & Taxa de Utilização de oxigênio & $\mathrm{mgO} / \mathrm{l} . \mathrm{h}$ \\
$\mathrm{Vr}$ & 15 & Volume do reator & 1 \\
$\mathrm{Nta}$ & 33,84 & Nitrogênio total afluente & $\mathrm{mgN} / \mathrm{l}$ \\
$\mathrm{Ntke}$ & 14,12 & Nitrogênio total efluente & $\mathrm{mgN} / \mathrm{l}$ \\
$\mathrm{Nna}$ & 5,38 & Nitrato no alfuente & $\mathrm{mgN} / \mathrm{l}$ \\
$\mathrm{Nne}$ & 4,83 & Nitrato no efluente & $\mathrm{mgN} / \mathrm{l}$ \\
& & & \\
$\mathrm{fn}$ & 0,1 & fração de Nitrogênio mo lodo &
\end{tabular}

O balanço de DQO e nitrogênio para o reator A foi o seguinte:

\section{$\underline{\text { Balanço de DQO }}$}

Massa de DQO efluente

$$
\text { Mdqoe=Q.Ste } \quad 570 \mathrm{mgDQO} / \text { ciclo }
$$

Massa de DQO no lodo

$$
\text { Mdqol=q.Xv.fcv }=\quad 1725 \mathrm{mgDQO} / \text { ciclo }
$$

Massa de oxigênio para nitrificação

$$
\text { Mon=Q.(Ntka-Ntke).4,57= } \quad 856 \mathrm{mgO}_{2} / \text { ciclo }
$$


Massa de DQO oxidada

Mdqoox=Ot.Vr.12-Mon=

DQO de saída

DQOs=Mdqoe + Mdqol+Mdqoox $=$

DQO de entrada

DQOe=Q.Sta $=$

Relação de DQO \%

$\% \mathrm{DQO}=(\mathrm{DQO} / \mathrm{DQOe}) .100$

Balanço de Nitrogênio

Massa de Nitrato no efluente

$$
\text { MNne=Q.Nne= }
$$

Massa de nitrato no afluente

$$
\mathrm{MNna}=\mathrm{Q} \cdot \mathrm{Nna}=
$$

Massa de NTK no efluente

$$
\text { MNte=Q.Ntke= }
$$

Massa de Nitrogênio no lodo

$$
\mathrm{MNl}=\mathrm{q} \cdot \mathrm{Xv} \cdot \mathrm{fn}=
$$

Massa de nitrogênio na saída

MNs=Mne + Mntke + Mnl=

Massa de Nitrogênio na entrada

$$
\mathrm{MNe}=\mathrm{Q} \cdot \mathrm{Ntka}+\mathrm{MNna}=
$$

Relação de Nitrogênio (\%)

$\% \mathrm{~N}=(\mathrm{MNs} / \mathrm{MNe}) \cdot 100=$
$2449 \mathrm{mgDQO} /$ ciclo

$4743 \mathrm{mgDQO} /$ ciclo

7116 mgDQO/ciclo

$67 \%$

$46 \mathrm{mgN} /$ ciclo

$51 \mathrm{mgN} /$ ciclo

$125 \mathrm{mgN} /$ ciclo

$178 \mathrm{mgN} /$ ciclo

$349 \mathrm{mgN} /$ ciclo

$373 \mathrm{mgN} /$ ciclo

$94 \%$ 
O balanço de DQO para o reator A da etapa controle apresentou um aumento nas quantidades de entrada e saída devido ao aumento da carga proporcionado pelo retorno do lodo após aplicação do ultra-som. Pode-se notar que houve um desbalanceamento mas, neste caso, a massa de DQO de saída foi menor que a de entrada. Como o aumento da DQO foi absorvido pelo reator, o que resulta numa DQO efluente muito próxima do valor da etapa controle, pode-se inferir que o aumento da DQO de entrada não gerou um aumento proporcional da DQO da biomassa.

O balanço de nitrogênio apresentou uma boa correlação, coincidindo com a melhora na nitrificação no reator A na etapa teste. Nota-se também valores mais altos na entrada e saída devido ao retorno do lodo.

Para o reator B, a tabela 5.7 ilustra os dados de entrada.

Tabela 5. 7 - Dados de entrada para o balanço de massa do reator B - Etapa teste.

\begin{tabular}{cccc}
\hline Parâmetros & $\begin{array}{c}\text { Dados de } \\
\text { entrada }\end{array}$ & Nomenclatura & unidade \\
\hline $\mathrm{Q}$ & 9,5 & Vazão afluente & $1 /$ ciclo \\
$\mathrm{q}$ & 0,935 & Vazão de lodo & $\mathrm{1} /$ ciclo \\
$\mathrm{Sta}$ & 716 & DQO afluente & $\mathrm{mg} / \mathrm{l}$ \\
$\mathrm{Ste}$ & 64 & DQO efluente & $\mathrm{mg} / \mathrm{l}$ \\
$\mathrm{fcv}$ & 1,17 & Razão DQO/SSV & $\mathrm{mg} \mathrm{DQO} / \mathrm{mg} \mathrm{SSV}$ \\
$\mathrm{Xv}$ & 2072,0 & SSV no tanque & $\mathrm{mgSSV} / \mathrm{l}$ \\
$\mathrm{Ot}$ & 20,01 & Taxa de Utilização de oxigênio & $\mathrm{mgO} / \mathrm{l} . \mathrm{h}$ \\
$\mathrm{Vr}$ & 15 & Volume do reator & 1 \\
$\mathrm{Ntka}$ & 30,62 & Nitrogênio total afluente & $\mathrm{mgN} / \mathrm{l}$ \\
$\mathrm{Ntke}$ & 2,28 & Nitrogênio total efluente & $\mathrm{mgN} / \mathrm{l}$ \\
$\mathrm{Nna}$ & 5,8 & Nitrato no afluente & \\
Nne & 11,8 & Nitrato no efluente & $\mathrm{mgN} / \mathrm{l}$ \\
$\mathrm{fn}$ & 0,1 & fração de Nitrogênio no lodo & $\mathrm{mgN} / \mathrm{l}$ \\
\hline
\end{tabular}

$\mathrm{O}$ balanço de $\mathrm{DQO}$ e nitrogênio para o reator $\mathrm{B}$ foi o seguinte: 
$\underline{\text { Balanço de DQO }}$

Massa de DQO efluente

Mdqoe=Q.Ste

Massa de DQO no lodo

$\mathrm{Mdqol}=\mathrm{q} \cdot \mathrm{Xv} \cdot \mathrm{fcv}=$

Massa de oxigênio para nitrificação

Mon=Q.(Ntka-Ntke).4,57=

Massa de DQO oxidada

Mdqoox=Ot.Vr.12-Mon=

DQO de saída

DQOs=Mdqoe + Mdqol+Mdqoox=

DQO de entrada

$$
\mathrm{DQOe}=\mathrm{Q} . \mathrm{Sta}=
$$

Relação de DQO \%

$\% \mathrm{DQO}=(\mathrm{DQO} / \mathrm{DQOe}) .100$

$\underline{\text { Balanço de Nitrogênio }}$

Massa de Nitrato no efluente

$$
\text { MNne=Q.Nne= }
$$

Massa de nitrato no afluente

$$
\mathrm{MNna}=\mathrm{Q} \cdot \mathrm{Nna}=
$$

Massa de NTK no efluente

$$
\text { MNte=Q.Ntke= }
$$

$608 \mathrm{mgDQO} /$ ciclo

$2267 \mathrm{mgDQO} /$ ciclo

$1230 \mathrm{mmO}_{2} /$ ciclo

$2371 \mathrm{mgDQO} /$ ciclo

$5246 \mathrm{mgDQO} /$ ciclo

$6802 \mathrm{mgDQO} /$ ciclo

$77 \%$

$112 \mathrm{mgN} /$ ciclo

$55 \mathrm{mgN} /$ ciclo

$20 \mathrm{mgN} /$ ciclo 
Massa de Nitrogênio no lodo

$$
\mathrm{MNl}=\mathrm{q} \cdot \mathrm{Xv} \cdot \mathrm{fn}=\quad \mathrm{mgN} / \text { ciclo }
$$

Massa de nitrogênio na saída

$$
\mathrm{MNs}=\mathrm{Mne}+\mathrm{Mntke}+\mathrm{Mnl}=\quad \mathrm{mgN} / \text { ciclo }
$$

Massa de Nitrogênio na entrada

$\begin{array}{ll}\mathrm{MNe}=\mathrm{Q} . \mathrm{Ntka}+\mathrm{MNna}= & 346 \\ \mathrm{mgN} / \text { ciclo }\end{array}$

Relação de Nitrogênio (\%)

$\% \mathrm{~N}=(\mathrm{MNs} / \mathrm{MNe}) \cdot 100=\quad 94 \%$

O mesmo caso ocorreu para o reator $\mathrm{B}$ no que diz respeito ao balanço de DQO. Houve novamente um desbalanceamento devido a uma menor DQO de saída em relação a DQO de entrada, sugerindo mais uma vez que a DQO não foi traduzida em biomassa. Nota-se também valores maiores de DQO na entrada e na saída devido ao retorno do lodo.

No caso do balanço de nitrogênio, o balanço final não sofreu grandes alterações em seu balanço pois o reator B já apresentava uma nitrificação na etapa controle. 


\section{Conclusões e Recomendações}

Os reatores apresentaram uma boa eficiência de remoção de DQO (em torno de $90 \%$ ) tanto para a etapa controle quanto para a etapa teste. O retorno do lodo lisado não afetou esta eficiência;

Houve um aumento no teor de sólidos suspensos voláteis no afluente e no tanque de aeração dos reatores A e B durante a etapa teste devido ao retorno do lodo lisado;

O reator A apresentou um aumento constante no teor de sólidos suspensos até aproximadamente o $140^{\circ}$ ciclo, quando permaneceu praticamente constante. Entretanto este aumento não causou nenhum dano em seu desempenho apesar de não ter havido descarte de lodo durante toda a etapa teste;

O IVL permaneceu em um patamar ótimo durante as duas etapas deste estudo para os dois reatores. Em momento algum houve bulking nos dois reatores;

Embora o reator A operasse com maior idade do lodo (12 dias), foi o reator B (idade do lodo de 8 dias)que apresentou uma melhor nitrificação nas duas etapas do estudo;

A eficiência de remoção de nitrogênio total foi alta tendo em vista um sistema aeróbio, indicando uma possível desnitrificação nos reatores;

Houve um aumento na concentração de DQO, nitrogênio e fósforo no afluente dos dois reatores durante a etapa teste devido ao retorno do lodo lisado. 
Entretanto este aumento melhorou a relação DQO/NTK resultando em uma melhor nitrificação nos dois reatores;

A taxa média de consumo de oxigênio foi menor na etapa teste que na etapa controle para os dois reatores, apesar do aumento da carga. O lodo lisado atuou como uma espécie de catalisador acelerando as reações, diminuindo a carga afleutent rapidamente com o tempo e assim diminuindo a taxa de consumo de oxigênio ao longo do ciclo;

Os balanços de massa para a DQO na etapa teste sugerem que a DQO não foi transformada em biomassa na mesma proporção que na etapa controle, sugerindo assim uma menor produção de lodo nos reatores, apesar do aumento da carga aplicada.

Deve-se estudar melhor o efeito do ultra-som em relação a concentração da amostra. Deve-se avaliar também outros tipos de desintegradores, maiores, mais econômicos e mais robustos, tais como, moinhos de bolas, homogenizadores a alta pressão, autoclave;

Para melhor avaliação dos resultados recomenda-se o estudo com esgoto real;

Fazer um estudo de viabilidade econômica do ultra-som e de outros tipos de desintegradores;

Estudar mais detalhadamente a menor produção de lodo quando da aplicação da lise, verificar a possível ação do lodo lisado como dissociador do catabolismo/anabolismo;

Medir a atividade enzimática do lodo lisado. 


\section{Referências Bibliográficas}

ABREU, L. M. (1994). Aspectos Microbiológicos de los Procesos de Nitrificación-

Desnitrificación, in: “III Taller Y Seminario Latino Americano: Tratamiento

Anaerobio de Aguas Residuales", p.55-64, Montevidéu, Uruguai

ALÉM SOBRINHO, P. (2001). Tratamento de Esgoto e Geração do Lodo. In: Biossólidos na Agricultura. Milton tomoyuki Tsutyia, João Baptista Comparini, Pedro Além Sobrinho, Ivanildo Hespanhol, Paulo de Campos Torres de Carvalho, Adolpho José Melphi, Wanderley José de Melo e Marcos Omir Marques (editores). SABESP, São Paulo.

ANDREOLI, C. V.; PINTO, M. A. T. (2001). Capítulo de Introdução In: Resíduos Sólidos de Saneamento: Processamento, Reciclagem e Disposição Final. Cleverson Vitório Andreoli (Coordenador), ABES, Rio de Janeiro.

APHA (1998). Standard Methods for the examination of Water and Wastewater. $20^{\mathrm{a}}$ ed., Washington, D.C.

BAIER, U.; SCHMIDHEINY, P. Enhanced Anaerobic Degradation of Mechanically Disintegrated Sludge. Wat. Sci. Tech. V. 36, n.11, pp 137-143.

BAILEY, J. E.; OLLIS, D. F. (1986). Biochemical Engineering Fundamentals, McGraw Hill, Singapore. 
BARKER, P. S.; DOLD, P. L. (1995). COD and Nitrogen Mass Balances in Activated Sludge Systems. Water Research, v. 29, n. 2, pp 663-643.

BERLINER, S. (1999).S. Berliner, III's Ultrasonics homepage. URL http://home.att.net/ Berliner-Ultrasonics/uson-3.html) . 10 de maio de 2002.

BIEN, J; WOLNY, L. (1997). Changes in some Sewage Sludge Parameters Prepared with an Ultrasonic Field. Wat. Sci. Tech. V. 36, n.11, pp 121-128.

BLUME, T.; MARTÍNEZ, I.; NEIS, U. (2002). Wastewater disinfection using Ultrasound and UV Light. In Technical University of Hamburg-Harburg Reports on Sanitary Engineering 35: Ultrasound in Environmental Engineering II. Hamburg. Neis U. (ed). pp 117-128.

BOMBERG, A; KRAMER, P (1988). Cell Disintegration by Highly Turbulent Liquid Impingement Jets - An Alternative Mechanical Disruption Procedure. in: DECHEMA Biotechnology Conferences: Bioreactors, Downstream Processes, Process and Reactor Modeling Bioprocesses, Frankfurt.

BRANCO, S. M. (1986). Hidrobiologia Aplicada a Engenharia Sanitária. CETESB, São Paulo.

CALlado, N. H. (2000). Reatores Seqüenciais em Batelada em Sistemas Anaeróbio/Aeróbio Tratando Esgoto Sanitário Sintético. Tese (Doutorado) Escola de engenharia de São Carlos, Universidade de São Paulo.

CAMPOS, J.R. (1994). Alternativas para Tratamento de Esgotos - Pré-Tratamento de Águas para Abastecimento, publicação n. 09, Consórcio Intermunicipal das Bacias dos Rios Piracicaba e Capivari, Americana, SP.

CASEY, T. G.; WENTZEL, M. C.; LOEWENTHAL, G. A.; EKAMA, G. A.; MARAI, G. v. R. (1992). A Hypothesis for the Cause of Low F/M Filament 
Bulking in Nutrient Removal Activated Sludge Systems. Water Research, v. 26, n. 6 , pp. $867-869$.

CRITES, R.; TCHBANOGLOUS, G. (2000) Tratamiento de Aguas Residuales en Pequeñas Poblaciones. MacGraw-Hill, Bogotá.

CHEN, G-H.; MO, H-K.; SABY, S.; YIP, W-K.; LIU, Y. (2000). Minimisation of Activated Sludge Production by Chemically Stimulated Energy Spilling. Wat. Sci. Tech. v. 42, n. 12, pp. 189-200.

CHIU, Y-C.; CHANG, C-N.; LIN, J-G.; HUANG, S-J. (1997). Alkaline and Ultrasonic Pretreatment of sludge before anaerobic digestion. Wat. Sci. Tech.. v. 36, n. 11, pp. 155-162.

CHU, C. P.; LEE, D. J.; CHANG, B-V.; YOU, C. S.; TAY, J.H. (1999). "Weak" Ultrasonic Pre-treatment on Anaerobic Digestion of Flocculated Activated Biosolids. Water research, v. 36, pp. 2681-2688.

DOHÁNYOS, M; ZÁBRANSKÁ, J; JENICECK, P.; STEPOVÁ, J.; KUTIL, V.;

HOREJS, J. (2000). The Intensification of Sludge Digestion by the Disintegration of Activated Sludge and the Thermal Conditioning of Digested Sludge. Wat. Sci. Tech. v. 42, n. 9, pp. 57-64.

DOHÁNYOS, M; ZÁBRANSKÁ, J; PAVEL, J. (1997). Enhancement of Sludge Anaerobic Digestion by Using of a Special Thickening Centrifuge. Wat. Sci. Tech.. v. 36, n. 11, pp. 145-153.

DOHÁNYOS, M; ZÁBRANSKÁ, J; PAVEL, J. (1997b). Innovative Technology for the Improvement of the Anaerobic Methane Fermentation. Wat. Sci. Tech. 36, v. 6-7, pp. 333-340. 
EIKELBOOM, D. H.(2000). Process Control of Activated Sludge Plants by microscopic Investigation. IWA Publishing, Londres.

ERDINCLER, A.; VESILIND, P. A. Effect of Sludge Cell Disruption on Compactibility of Biological Sludges. Wat. Sci. Tech., v. 42, n. 9, pp. 119-126.

FERNANDES, F. (1997). Biossólidos, Lodos de ETA e o Programa de Pesquisa. Informe Especial, ano 9, n2, mai/jun, p.41, Revista BIO, ABES, Rio de Janeiro.

FERNANDES, F.; SOUZA, S. G. (2001). Estabilização de Lodo de Esgoto. In: Resíduos Sólidos de Saneamento: Processamento, Reciclagem e Disposição Final. Cleverson Vitório Andreoli (Coordenador), ABES, Rio de Janeiro.

FERNANDES.F; LOPES, D. D.; ANDREOLI, C. V.; SILVA, S. M. C. P. (2001). Avaliação de Alternativas e Gerenciamento de Lodo na ETE. In: Princípio do Tratamento Biológico de Águas Residuárias - Lodos de Esgotos: Tratamento e Disposição Final. Cleverson Vitório Andreoli, Marcos Von Sperling e Fernando Fernandes (editores). DESA - UFMG, SANEPAR, Belo Horizonte.

GONCALVES, R. F.; LUDUVICE, M. (2000). Alternativas de Minimização da Produção e Desaguamento de Lodo de Esgoto. In: Impacto Ambiental do Uso Agrícola do Lodo de Esgoto. Wagner Bettiol e Otávio A. Camargo (editores). EMBRAPA Meio Ambiente, Jaguariúna.

HANNELORE, F.; POTTHOFF, A.; FRIEDERICH, E.; HIELSCHER, H. (1999). Improving Settling Properties and Dewaterability of Sewage Sludges by Application of the Ultrasound Technology. In Technical University of Hamburg-Harburg Reports on Sanitary Engineering 25: Ultrasound in Environmental Engineering. Hamburg. Tiehm A. \& Neis U. (eds). pp 245-255. 
HIGGINS, J. A.; SPRINGER, A. M. (1998). Reducing excess Biological sludge in the Activated-sludge Process. (Relatório interno - Miami University).

JENKINS, D.; RICHARD, M. G. \& DAIGGER, G. T. (1993), Manual on the Causes and Control of Activated Sludge Bulking and Foaming, $2^{\mathrm{a}}$ Ed., Lewis Publishers, Inc, Estados Unidos.

JETTEN, M. S. M. et al (1997). Novel Principles in the Microbial Conversion of Nitrogen Compounds, Antonie van Leeuwenhoek, 71, p.75-93

LAWSON, B. S. (1993). Study of the Effects of Primary Sludge Disintegration on the Performance of an Anaerobic Sludge Digester. Master Thesis, Miami University, Oxford.

LEHNE, G.; MULLER, A. (1991). The influence of the Energy Consumption on the Sewage sludge Disintegration In Technical University of Hamburg-Harburg Reports on Sanitary Engineering 25: Ultrasound in Environmental Engineering. Hamburg. Tiehm A. \& Neis U. (eds). pp 205-215.

LEHNE, G.; MULLER, A.; SHWEDES, J.(1999). Mechanical Disintegration and Anaerobic Digestion of Sewage Sludge. In: IAWQ Conference on Disposal and Utilization of Sewage Sludge, Athens, Greece.

LIN, J-G; MA, Y-S; HUANG, C-C. (1998). Alkaline Hydrolysis of the Sludge Generated From a High-Strength, Nitrogenous-Wastewater Biological Treatment Process. Bioresource Technology, 65, pp 35-42.

LIU, Y., TAY, J-H. (2001). Strategy for minimization of excess sludge production from the activated sludge process. Biotechnology Advances 19(2), pp. 97-107.

LUDUVICE, M. (1998). Gestão de Biossólidos e o Mercosul, in: I Seminário sobre gerenciamento de Biossólidos do Mercosul. SANEPAR/ABES, Curitiba. 
MASON, T. J. (1999). Ultrasound in environmental protection - an overview. In:Technical University of Hamburg-Harburg Reports on Sanitary Engineering 25: Ultrasound in Environmental Engineering. Tiehm A. \& Neis U. (ee.). Hamburg. pp 1-10.

MATTHEWS, P.J. (1992). Sewage Sludge Disposal in the UK: A new Challenge for the Next Twenty Years . Journal of the Institution of Water Environmental Management, v.6, pp 551-559, out.

MAYHEW, M.; STEPHENSON, T. (1998). Biomass Yield Reduction: Is Biochemical Manipulation Possible Without Affecting Activated Sludge Process Efficiency? Wat. Sci. Tech. v. 38, n. 89, pp. 137-144.

MENDONÇA, S.R. (1993). Tratamento de lodos, in: Curso sobre projeto de estação de tratamento de esgotos, Brasília, 22 a 26 mar.

MENDONÇA, L. C.; OLIVEIRA, A. L.; GIANOTTI, E. P.; CAMPOS, J. R.; BLUNDI, C. E.†.(2001). Caracterização Microbiológica de um Sistema de Remoção de Nitrogênio em Batelada. In: $21^{\circ}$ Congresso Brasileiro de Engenharia Sanitária e Ambiental, ABES, João Pessoa.

METCALF \& EDDY (1991). Wastewater Engineering: Treatment, Disposal, Reuse, 3- edição, McGraw-Hill, 1334p., Nova York, Estados Unidos

MIKI, M. K.; ANDRIGUETI, E. J.; ALÉM SOBRINHO, P.(2001). Tratamento da Fase Sólida em Estações de Tratamento de Esgotos. In: Biossólidos na Agricultura. Milton Tomoyuki Tsutiya, João Baptista Comparini, Pedro Além Sobrinho, Ivanildo Hespanhol, Paulo de Campos Torres de Carvalho, Adolpho José Melphi, Wanderley José de Melo e Marcos Omir Marques (editores). SABESP, São Paulo. 
MULLER, J. (1998). Sewage Sludge Disintegration - Research and Application, Newsletter IAWQ Specialist Group on Sludge Management, Out 1998, pp 9-11.

MULLER, J. (2000). Disintegration as a key-step in sewage sludge minimization. Wat. Sci. Tech. v. 41, n.8, pp. 123-130.

MULLER, J. (2001). Prospects and Problems of Sludge Pre-treatment Processes. Wat. Sci. Tech., 44, v. 10, pp. 121-128.

MUlleR, J.; LEHNE, G.; PIEPER, P.; DICHTL, N. (2000). Mechanical Disintegration of Sewage Sludge. $1^{\text {st }}$ World Congress of the International Water Association, Paris.

MULLER, J.; LEHNE, G.; SCHWEDES, J.; BATTENBERG, S.; NAVEKE, R.; KOPP, J.; DICHTL, N.; SCHEMINSKI, A.; KRULL, R.; HEMPEL, D.C. (1998) Disintegration of Sewage Sludge and Influence on Anaerobic Digestion. Wat. Sci. Tech., v. 38, n. 8-9, pp. 425-433.

NEIS, U.(2000). Ultrasound in Water, Wastewater and Sludge Treatment. Water 21, April, pp. 36-39.

NEIS, U.; TIEHM A. (1999). Ultrasound in Wastewater Treatment. In Technical University of Hamburg-Harburg Reports on Sanitary Engineering 25: Ultrasound in Environmental Engineering. Tiehm A. \& Neis U. (ee). Hamburg. pp 39-61.

NICKEL, K. (1999). Improving Anaerobic Degradation by Ultrasonic Disintegration of Sewage Sludge. In: Technical University of HamburgHarburg Reports on Sanitary Engineering 25: Ultrasound in Environmental Engineering. Tiehm A. \& Neis U. (ee), Hamburg, pp 217-232. 
NOLASCO, M. A. (1998). Redução da Produção de lodo no tratamento aeróbio de efluentes da indústria de celulose e papel. São Carlos. 170 pp. Tese (Doutorado) - Escola de Engenharia de São Carlos, Universidade de São Paulo.

NOLASCO, M. A.; CAMPOS, A. L. O.; SPRINGER, A. M.; PIRES, E. C.(2001). Use of Lysis and Recycle to Control Excess Sludge Production in Activated Sludge Treatment: Bench Scale study and effect of Chlorinated Organic Compounds. In: IWA Specialized Conference on Sludge Management: Regulation, Treatment, Utilization and Disposal. Acapulco, México.

OLIVEIRA, A. L. (2001). Influência do Tipo de Matéria Orgânica no Processo de Desnitrificação em Reatores seqüenciais em Batelada. Dissertação (Mestrado) - Escola de engenharia de São Carlos, Universidade de São Paulo.

PÉTRIER, C.; JIANG, A.; LAMY, M-F. (1999). Aromatics and Chloroaromatics Sonochemical Degradation: Yields and By-products. In: Technical University of Hamburg-Harburg Reports on Sanitary Engineering 25: Ultrasound in Environmental Engineering. Tiehm A. \& Neis U. (ee). Hamburg. pp 23-37.

PHULl, S. S.; NEWMAN, A. P.; LORIMER, J. P.; POLlET, B.; MASON, J. T. (1997). The Development and Evaluation of Ultrasound in the Biocidal Treatment. Ultrasonics Sonochemistry, 4, pp 157-164.

PHULL, S. S.; STERNAGEL, M..; LORIMER, J. P.; POLLET, B.; MASON, J. T. (1999). The Use of Ultrasound for remediation of biological Decontamination in Water. In: Technical University of Hamburg-Harburg Reports on Sanitary Engineering 25: Ultrasound in Environmental Engineering. Tiehm A. \& Neis U. (ee). Hamburg. pp 181-188. 
PORTENLÄNGER, T. (1999). Mechanical and Radical Effects of Ultrasound. In: Technical University of Hamburg-Harburg Reports on Sanitary Engineering 25: Ultrasound in Environmental Engineering. Tiehm A. \& Neis U. (ee). Hamburg. pp 11-22.

PUHLER, A; STADLER, P. (1993). Mechanical Methods of Cell Disruption. In: Biotechnology: A Multi Volume Comprehensive Treatise, New York.

ROGALlA, F. (1998). Produção, Caracterização e Processamento de Biossólidos. in: I Seminário sobre gerenciamento de Biossólidos do Mercosul. SANEPAR/ABES, Curitiba.

ROJAS, J. A. R. (2000). Tratamiento de Aguas Residuales: Teoría y Principios de Diseño. Escuela Colombiana de Ingeniería, Bogotá.

SANTOS, H.F; TSUTYIA, M.T (1997). Aproveitamento e disposição Final do Lodo de Estações de Tratamento do Estado de São Paulo. Engenharia Sanitária e Ambiental, v. 2, n 2, abrfun, pp. 70-81, ABES, Rio de Janeiro.

SCHMIDT, E. L. \& BELSER, L. W. (1984), Nitrifying Bacteria, in: "Methods of Soil Analysis - Chemical and Microbiological Properties", Number 9, Part 2, 2 Ed., p.1027-1042, Wisconsin, Estados Unidos

SCHMITZ, U.; BERGER, C. R.; ORTH, H. Protein Analysis as a Simple Method for the Quantitative Assessment of Sewage Sludge Disintegration. Water Research, v.34, n. 14, pp. 3682-3685.

SHIMIZU, T; KUDO, K; YOSHIKAZU, N. (1993). Anaerobic Waste-activated sludge digestion - A Bioconversion Mechanism and Kinetic Model. Biotechnology and Bioengineering, v. 41, pp. 1082 - 1091. 
SPERANDIO, M.; PAUL, E. Estimation of Wastewater Biodegrade COD Fractions by Combining Respirometric Experiments in Various So/Xo Ratios. Water Research, v. 34, n. 4, pp. 1233-1246.

SPRINGER, A. M.; DIETRICH-VELAZQUEZ, G.; HIGBY, C. M.; DIGIACOMO, D. (1996). Feasibility Study of Sludge Lysis and Recycle in the activatedsludge Process. TAPPI Journal, 79 (5), pp.162-170.

TIEHM, A; NICKEL, K; NEIS, U.(1997). The Use of Ultrasound to Accelerate the Anaerobic Digestion of Sewage Sludge. Wat. Sci. Tech.. v. 36, n. 11, pp. 121128.

TORRES, P. (1992). Desempenho de um reator anaeróbio de manta de lodo (UASB) de bancada no tratamento de substrato sintético simulando esgoto sanitário sob diferentes condições de operação. São Carlos. Dissertação (Mestrado) - Escola de Engenharia de São Carlos, Universidade de São Paulo.

VAN HAANDEL, A; GUIMARÃES, P.(2000). Modelamento do Tratamento Anaeróbio-Aeróbio Usando-se o Reator UASB e lodos Ativados em Bateladas Seqüenciais. Pós-tratamento de Efluentes Anaeróbios: Coletânea de Trabalhos. Carlos Augusto Lemos Chernicharo - Coordenador. Projeto PROSAB, Belo Horizonte.

VAN HAANDEL, A; MARAIS, G. (1999). O Comportamento do Sistema de Lodo Ativado. Epgraf, Campina Grande.

VAZOLLER, R. F. (1989), Microbiologia de Lodos Ativados, Série Manuais, Companhia de Tecnologia de Saneamento Ambiental, São Paulo. 
VON SPERLING, M. (1996). Princípio do Tratamento Biológico de Águas Residuárias. Vol. 1. Introdução à Qualidade das Águas e ao Tratamento de Esgotos. DESA, UFMG, Belo Horizonte.

VON SPERLING, M. (1997). Princípio do Tratamento Biológico de Águas Residuárias - Lodos Ativados. DESA, UFMG, Belo Horizonte.

WEF (1996). Operation of Municipal Wastewater Treatment Plants. Water Environment Federation, Alexandria.

YASUI, H.; SHIBATA, M. (1994). An Innovative Approach to Reduce Excess Sludge Production in the Activated Sludge Process. Wat.Sci. Tech. v. 30, n. 9, pp 11-20. 
ANEXO 
ANÁLISE DE DQO - ETAPA CONTROLE

\begin{tabular}{c|c|c|c|c|c|c|c|c|}
\hline & \multicolumn{9}{c|}{ BRUTA } \\
\hline Tempo & Afluente A & Afluente A & Afluente B & Afluente B & Efluente A & Efluente A & Efluente B & Efluente B \\
\hline 0 & 641 & 608 & 586 & 523 & 23 & 36 & 34 & 45 \\
\hline 16 & 559 & 619 & 527 & 556 & 30 & 25 & 43 & 56 \\
\hline 28 & 537 & 542 & 505 & 506 & 45 & 46 & 51 & 47 \\
\hline 38 & 492 & 463 & 638 & 583 & 50 & 55 & 84 & 56 \\
\hline 42 & 563 & 548 & 535 & 555 & 51 & 50 & 50 & 53 \\
\hline 52 & 565 & 545 & 513 & 516 & 41 & 44 & 50 & 42 \\
\hline 56 & 558 & 560 & 494 & 510 & 51 & 51 & 54 & 55 \\
\hline 68 & 583 & 579 & 702 & 667 & & 64 & 82 & 72 \\
\hline 72 & 607 & 541 & 626 & 581 & 47 & 46 & 54 & 71 \\
\hline 96 & 644 & 721 & 694 & 690 & 58 & 47 & 79 & 76 \\
\hline 106 & 785 & & 480 & & 66 & & 105 & \\
\hline 122 & 476 & & 519 & & 67 & & 81 & \\
\hline 138 & 591 & & 486 & & 49 & & 73 & \\
\hline 152 & 560 & & 563 & & 75 & & 60 & \\
\hline 166 & 503 & & 444 & & 54 & & 102 & \\
\hline 180 & 534 & & 408 & & 24 & & 20 & \\
\hline média & 575 & 573 & 545 & 569 & 49 & 46 & 64 & 57 \\
Desvio & 75 & 67 & 79 & 64 & 14 & 10 & 22 & 12 \\
\hline
\end{tabular}


ANÁLISE DE DQO - ETAPA CONTROLE - Cont.

\begin{tabular}{|c|c|c|c|c|c|c|c|c|}
\hline & \multicolumn{8}{|c|}{ FILTRADA } \\
\hline Tempo & Afluente A & Afluente A & Afluente B & Afluente B & Efluente A & Efluente A & Efluente B & Efluente B \\
\hline 0 & 423 & 430 & 399 & 379 & 25 & 24 & 30 & 34 \\
\hline 16 & 361 & 359 & 378 & 384 & 17 & & 10 & 11 \\
\hline 28 & 453 & 432 & 365 & 384 & 18 & 17 & 16 & 19 \\
\hline 38 & 377 & 396 & 505 & 510 & 39 & 45 & 38 & 42 \\
\hline 42 & 426 & 405 & 418 & 458 & 28 & 37 & 22 & 15 \\
\hline 52 & 421 & 510 & 369 & 363 & 16 & 23 & 16 & 14 \\
\hline 56 & 434 & 473 & 399 & 364 & 15 & 18 & 16 & \\
\hline 68 & 463 & 480 & 471 & & 20 & 35 & 19 & 19 \\
\hline 72 & 507 & 474 & 462 & 416 & 35 & 22 & 44 & 22 \\
\hline 96 & 513 & 414 & 409 & 423 & 32 & 41 & 22 & 27 \\
\hline 106 & 564 & & 345 & & 46 & & 41 & \\
\hline 122 & 408 & & 389 & & 15 & & 19 & \\
\hline 138 & 464 & & 403 & & 29 & & 40 & \\
\hline 152 & 518 & & 500 & & 60 & & 58 & \\
\hline 166 & 405 & & 372 & & 48 & & 47 & \\
\hline 180 & 413 & & 322 & & 20 & & 20 & \\
\hline média & 447 & 437 & 407 & 409 & 29 & 29 & 29 & 23 \\
\hline Desvio & 56 & 46 & 50 & 49 & 14 & 11 & 14 & 10 \\
\hline
\end{tabular}


ANALISE DE DQO - ETAPA TESTE

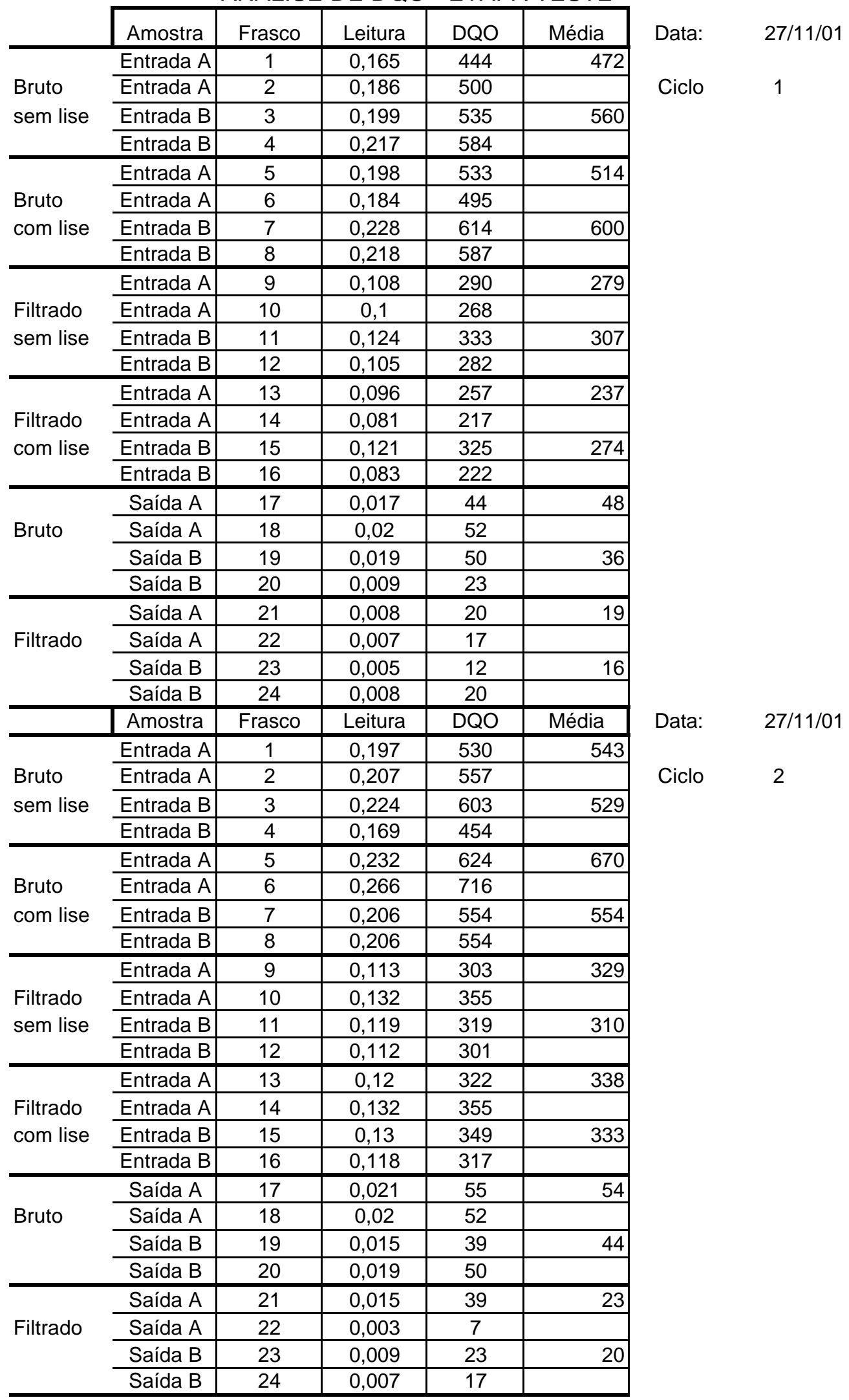


ANALISE DE DQO - ETAPA TESTE - Cont.

\begin{tabular}{|c|c|c|c|c|c|c|c|}
\hline & Amostra & Frasco & Leitura & DQO & Média & Data: & $28 / 11 / 01$ \\
\hline \multirow{4}{*}{$\begin{array}{l}\text { Bruto } \\
\text { sem lise }\end{array}$} & Entrada A & 1 & 0,259 & 697 & 689 & \multirow{24}{*}{ Ciclo } & \\
\hline & Entrada $\mathrm{A}$ & 2 & 0,253 & 681 & & & 3 \\
\hline & Entrada B & 3 & 0,187 & 503 & 508 & & \\
\hline & Entrada B & 4 & 0,191 & 514 & & & \\
\hline \multirow{4}{*}{$\begin{array}{l}\text { Bruto } \\
\text { com lise }\end{array}$} & Entrada A & 5 & 0,302 & 813 & 767 & & \\
\hline & Entrada $\mathrm{A}$ & 6 & 0,268 & 721 & & & \\
\hline & Entrada B & 7 & 0,25 & 673 & 670 & & \\
\hline & Entrada B & 8 & 0,248 & 667 & & & \\
\hline \multirow{4}{*}{$\begin{array}{l}\text { Filtrado } \\
\text { sem lise }\end{array}$} & Entrada $\mathrm{A}$ & 9 & 0,141 & 379 & 376 & & \\
\hline & Entrada A & 10 & 0,139 & 373 & & & \\
\hline & Entrada B & 11 & 0,104 & 279 & 288 & & \\
\hline & Entrada B & 12 & 0,111 & 298 & & & \\
\hline \multirow{4}{*}{$\begin{array}{l}\text { Filtrado } \\
\text { com lise }\end{array}$} & Entrada A & 13 & 0,141 & 379 & 388 & & \\
\hline & Entrada $\mathrm{A}$ & 14 & 0,148 & 398 & & & \\
\hline & Entrada B & 15 & 0,127 & 341 & 319 & & \\
\hline & Entrada B & 16 & 0,111 & 298 & & & \\
\hline \multirow{4}{*}{ Bruto } & Saída A & 17 & 0,031 & 82 & 79 & & \\
\hline & Saída A & 18 & 0,029 & 77 & & & \\
\hline & Saída B & 19 & 0,023 & 60 & 66 & & \\
\hline & Saída B & 20 & 0,027 & 71 & & & \\
\hline \multirow{5}{*}{ Filtrado } & Saída A & 21 & 0,024 & 63 & 46 & & \\
\hline & Saída A & 22 & 0,011 & 28 & & & \\
\hline & Saída B & 23 & 0,013 & 34 & 34 & & \\
\hline & Saída B & 24 & 0,013 & 34 & & & \\
\hline & Amostra & Frasco & Leitura & DQO & Média & \multirow[t]{2}{*}{ Data: } & $01 / 12 / 01$ \\
\hline \multirow{4}{*}{$\begin{array}{l}\text { Bruto } \\
\text { sem lise }\end{array}$} & Entrada $\mathrm{A}$ & 1 & 0,262 & 705 & 701 & & \\
\hline & Entrada A & 2 & 0,259 & 697 & & \multirow[t]{23}{*}{ Ciclo } & 8 \\
\hline & Entrada B & 3 & 0,206 & 554 & 561 & & \\
\hline & Entrada B & 4 & 0,211 & 568 & & & \\
\hline \multirow{4}{*}{$\begin{array}{l}\text { Bruto } \\
\text { com lise }\end{array}$} & Entrada A & 5 & 0,308 & 829 & 840 & & \\
\hline & Entrada $\mathrm{A}$ & 6 & 0,316 & 851 & & & \\
\hline & Entrada B & 7 & 0,278 & 748 & 778 & & \\
\hline & Entrada B & 8 & 0,3 & 808 & & & \\
\hline \multirow{4}{*}{$\begin{array}{l}\text { Filtrado } \\
\text { sem lise }\end{array}$} & Entrada $\mathrm{A}$ & 9 & 0,158 & 425 & 430 & & \\
\hline & Entrada A & 10 & 0,162 & 435 & & & \\
\hline & Entrada B & 11 & 0,13 & 349 & 350 & & \\
\hline & Entrada B & 12 & 0,131 & 352 & & & \\
\hline \multirow{4}{*}{$\begin{array}{l}\text { Filtrado } \\
\text { com lise }\end{array}$} & Entrada A & 13 & 0,136 & 365 & 377 & & \\
\hline & Entrada $\mathrm{A}$ & 14 & 0,145 & 390 & & & \\
\hline & Entrada B & 15 & 0,128 & 344 & 337 & & \\
\hline & Entrada B & 16 & 0,123 & 330 & & & \\
\hline \multirow{4}{*}{ Bruto } & Saída A & 17 & 0,018 & 47 & 48 & & \\
\hline & Saída A & 18 & 0,019 & 50 & & & \\
\hline & Saída B & 19 & 0,012 & 31 & 29 & & \\
\hline & Saída B & 20 & 0,011 & 28 & & & \\
\hline \multirow{4}{*}{ Filtrado } & Saída A & 21 & 0,015 & 39 & 46 & & \\
\hline & Saída A & 22 & 0,02 & 52 & & & \\
\hline & Saída B & 23 & 0,022 & 58 & 51 & & \\
\hline & Saída B & 24 & 0,017 & 44 & & & \\
\hline
\end{tabular}


ANALISE DE DQO - ETAPA TESTE - Cont.

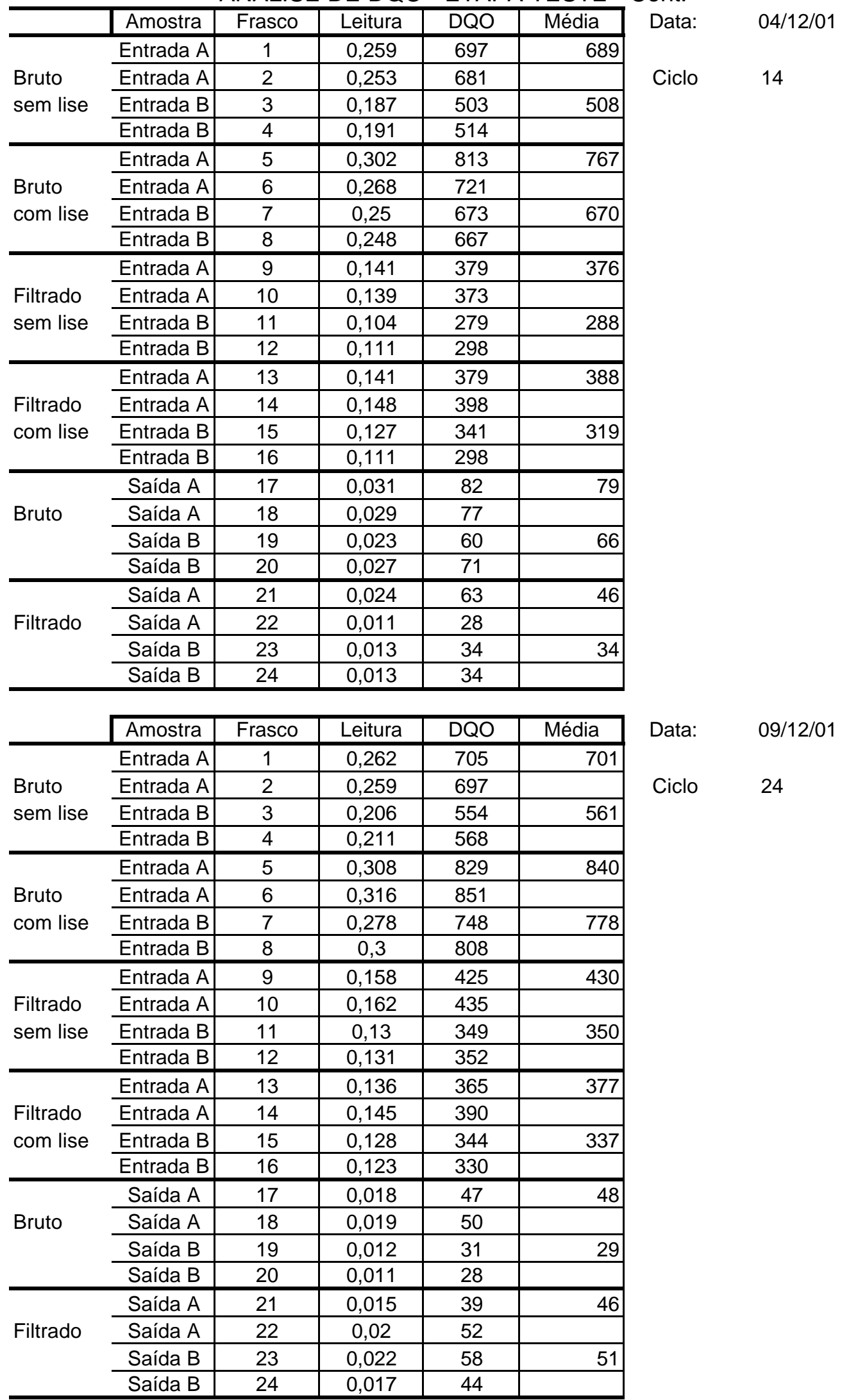


ANALISE DE DQO - ETAPA TESTE - Cont.

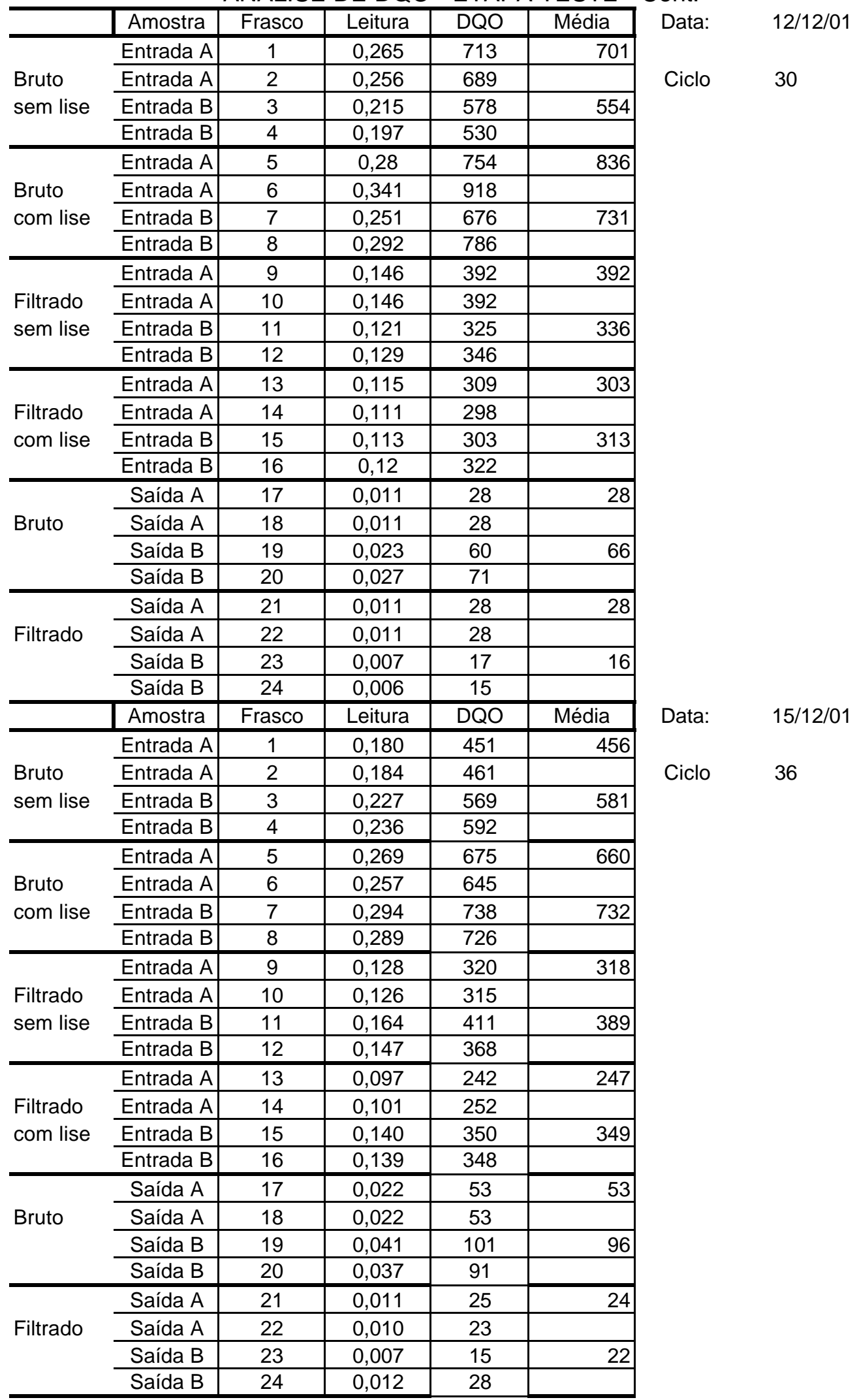


ANALISE DE DQO - ETAPA TESTE - Cont.

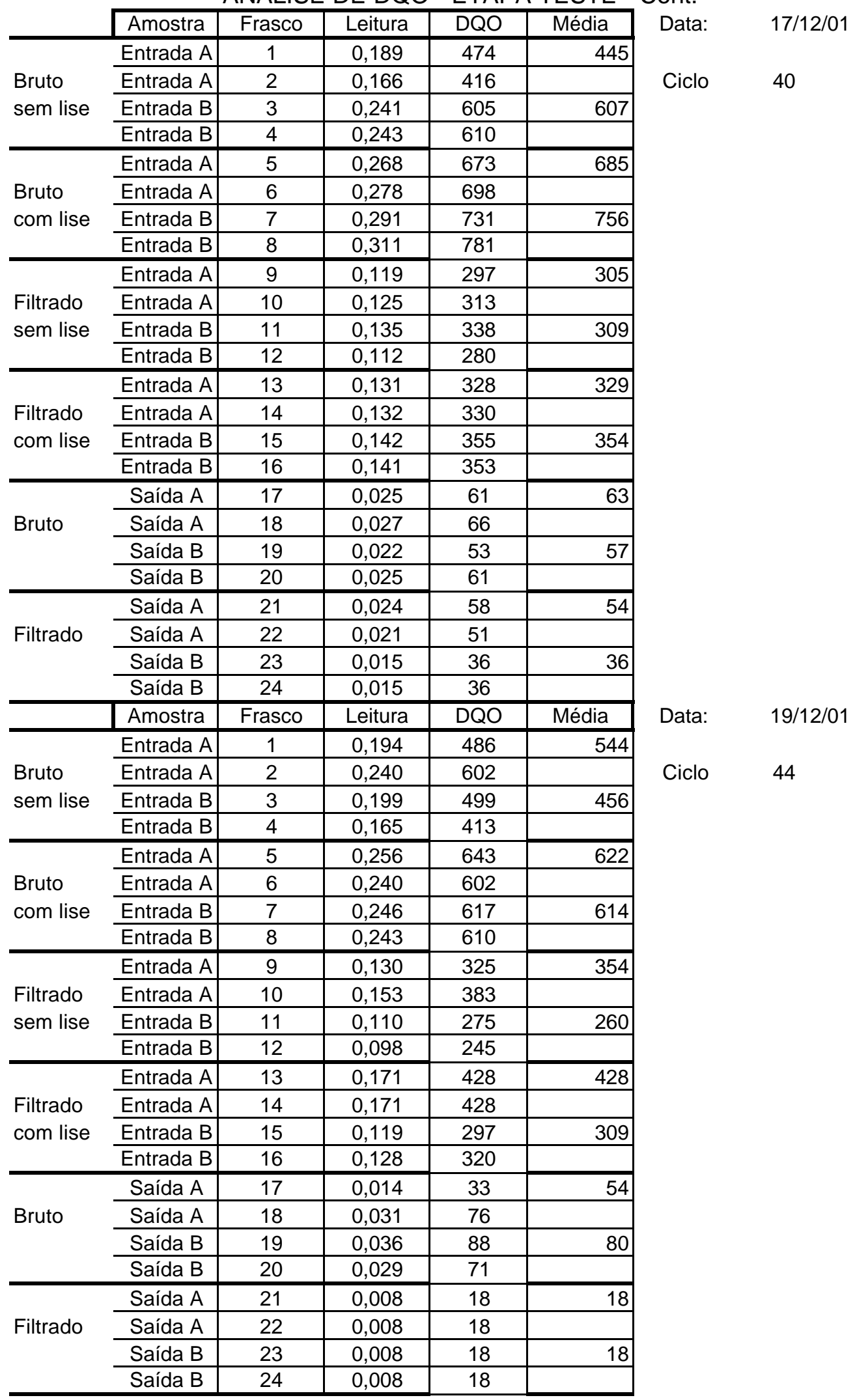


ANALISE DE DQO - ETAPA TESTE - Cont.

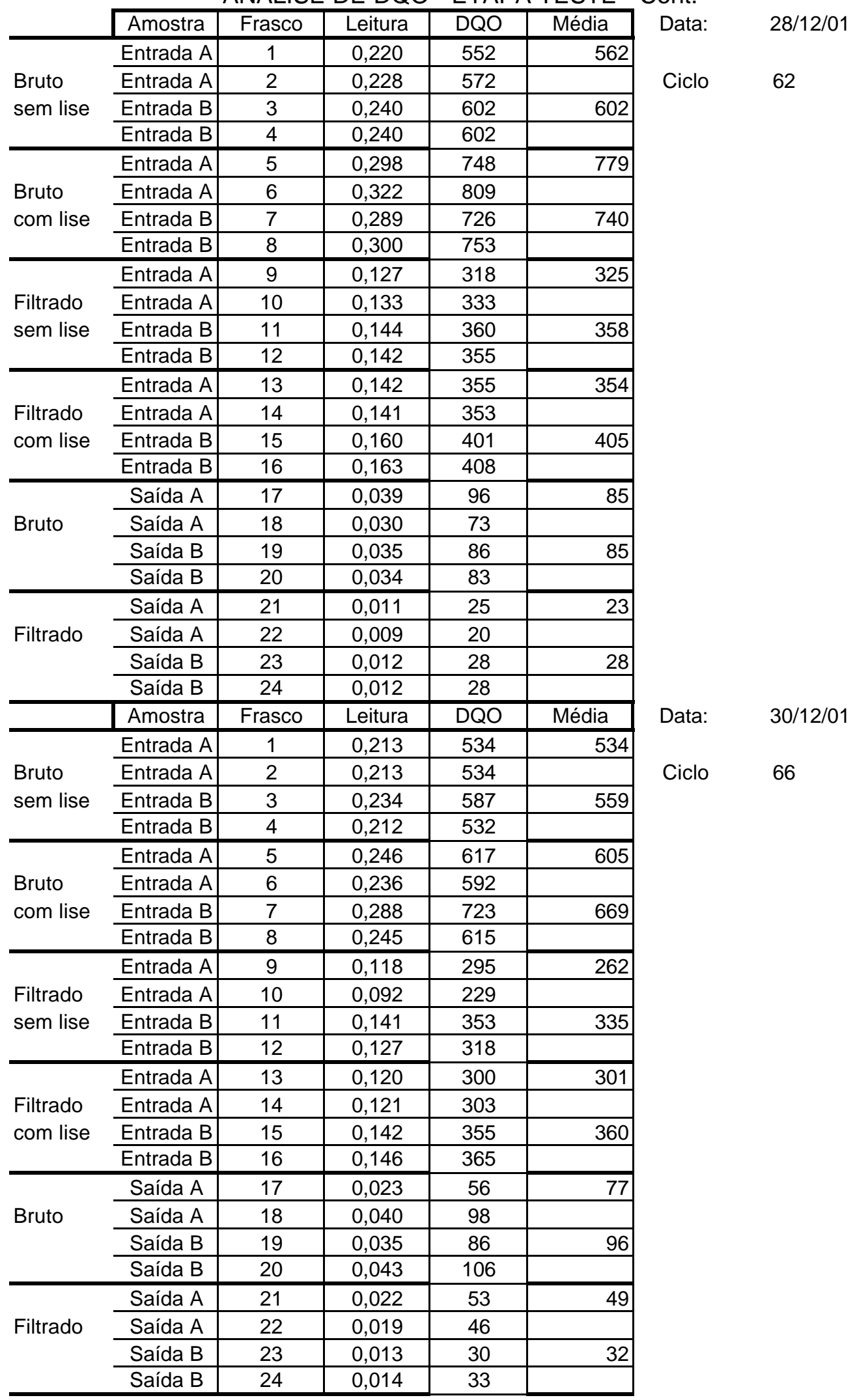


ANALISE DE DQO - ETAPA TESTE - Cont.

\begin{tabular}{|c|c|c|c|c|c|c|c|}
\hline & Amostra & Frasco & Leitura & DQO & Média & Data: & 03/01/02 \\
\hline \multirow{4}{*}{$\begin{array}{l}\text { Bruto } \\
\text { sem lise }\end{array}$} & Entrada $\mathrm{A}$ & 1 & 0,221 & 554 & 534 & \multirow{24}{*}{ Ciclo } & \multirow{24}{*}{74} \\
\hline & Entrada $\mathrm{A}$ & 2 & 0,205 & 514 & & & \\
\hline & Entrada B & 3 & 0,165 & 413 & 427 & & \\
\hline & Entrada B & 4 & 0,176 & 441 & & & \\
\hline \multirow{4}{*}{$\begin{array}{l}\text { Bruto } \\
\text { com lise }\end{array}$} & Entrada A & 5 & 0,250 & 627 & 651 & & \\
\hline & Entrada $\mathrm{A}$ & 6 & 0,269 & 675 & & & \\
\hline & Entrada B & 7 & 0,235 & 590 & 590 & & \\
\hline & Entrada B & 8 & 0,235 & 590 & & & \\
\hline \multirow{4}{*}{$\begin{array}{l}\text { Filtrado } \\
\text { sem lise }\end{array}$} & Entrada $\mathrm{A}$ & 9 & 0,125 & 313 & 297 & & \\
\hline & Entrada A & 10 & 0,113 & 282 & & & \\
\hline & Entrada B & 11 & 0,118 & 295 & 274 & & \\
\hline & Entrada B & 12 & 0,101 & 252 & & & \\
\hline \multirow{4}{*}{$\begin{array}{l}\text { Filtrado } \\
\text { com lise }\end{array}$} & Entrada A & 13 & 0,128 & 320 & 325 & & \\
\hline & Entrada $\mathrm{A}$ & 14 & 0,132 & 330 & & & \\
\hline & Entrada B & 15 & 0,106 & 265 & 274 & & \\
\hline & Entrada B & 16 & 0,113 & 282 & & & \\
\hline \multirow{4}{*}{ Bruto } & Saída A & 17 & 0,031 & 76 & 107 & & \\
\hline & Saída A & 18 & 0,056 & 139 & & & \\
\hline & Saída B & 19 & 0,038 & 93 & 86 & & \\
\hline & Saída B & 20 & 0,032 & 78 & & & \\
\hline \multirow{5}{*}{ Filtrado } & Saída A & 21 & 0,019 & 46 & 38 & & \\
\hline & Saída A & 22 & 0,013 & 30 & & & \\
\hline & Saída B & 23 & 0,019 & 46 & 42 & & \\
\hline & Saída B & 24 & 0,016 & 38 & & & \\
\hline & Amostra & Frasco & Leitura & DQO & Média & \multirow[t]{2}{*}{ Data: } & \multirow[t]{2}{*}{ 07/01/02 } \\
\hline \multirow{4}{*}{$\begin{array}{l}\text { Bruto } \\
\text { sem lise }\end{array}$} & Entrada A & 1 & 0,224 & 562 & 558 & & \\
\hline & Entrada $\mathrm{A}$ & 2 & 0,221 & 554 & & \multirow[t]{23}{*}{ Ciclo } & \multirow[t]{23}{*}{82} \\
\hline & Entrada B & 3 & 0,203 & 509 & 524 & & \\
\hline & Entrada B & 4 & 0,215 & 539 & & & \\
\hline \multirow{4}{*}{$\begin{array}{l}\text { Bruto } \\
\text { com lise }\end{array}$} & Entrada A & 5 & 0,297 & 746 & 756 & & \\
\hline & Entrada A & 6 & 0,305 & 766 & & & \\
\hline & Entrada B & 7 & 0,273 & 685 & 639 & & \\
\hline & Entrada B & 8 & 0,236 & 592 & & & \\
\hline \multirow{4}{*}{$\begin{array}{l}\text { Filtrado } \\
\text { sem lise }\end{array}$} & Entrada A & 9 & 0,147 & 368 & 374 & & \\
\hline & Entrada A & 10 & 0,152 & 381 & & & \\
\hline & Entrada B & 11 & 0,129 & 323 & 321 & & \\
\hline & Entrada B & 12 & 0,128 & 320 & & & \\
\hline \multirow{4}{*}{$\begin{array}{l}\text { Filtrado } \\
\text { com lise }\end{array}$} & Entrada $\mathrm{A}$ & 13 & 0,141 & 353 & 358 & & \\
\hline & Entrada $\mathrm{A}$ & 14 & 0,145 & 363 & & & \\
\hline & Entrada B & 15 & 0,133 & 333 & 323 & & \\
\hline & Entrada B & 16 & 0,125 & 313 & & & \\
\hline \multirow{4}{*}{ Bruto } & Saída A & 17 & 0,023 & 56 & 59 & & \\
\hline & Saída A & 18 & 0,026 & 63 & & & \\
\hline & Saída B & 19 & 0,037 & 91 & 96 & & \\
\hline & Saída B & 20 & 0,041 & 101 & & & \\
\hline \multirow{4}{*}{ Filtrado } & Saída A & 21 & 0,014 & 33 & 33 & & \\
\hline & Saída A & 22 & 0,014 & 33 & & & \\
\hline & Saída B & 23 & 0,014 & 33 & 27 & & \\
\hline & Saída B & 24 & 0,009 & 20 & & & \\
\hline
\end{tabular}


ANALISE DE DQO - ETAPA TESTE - Cont.

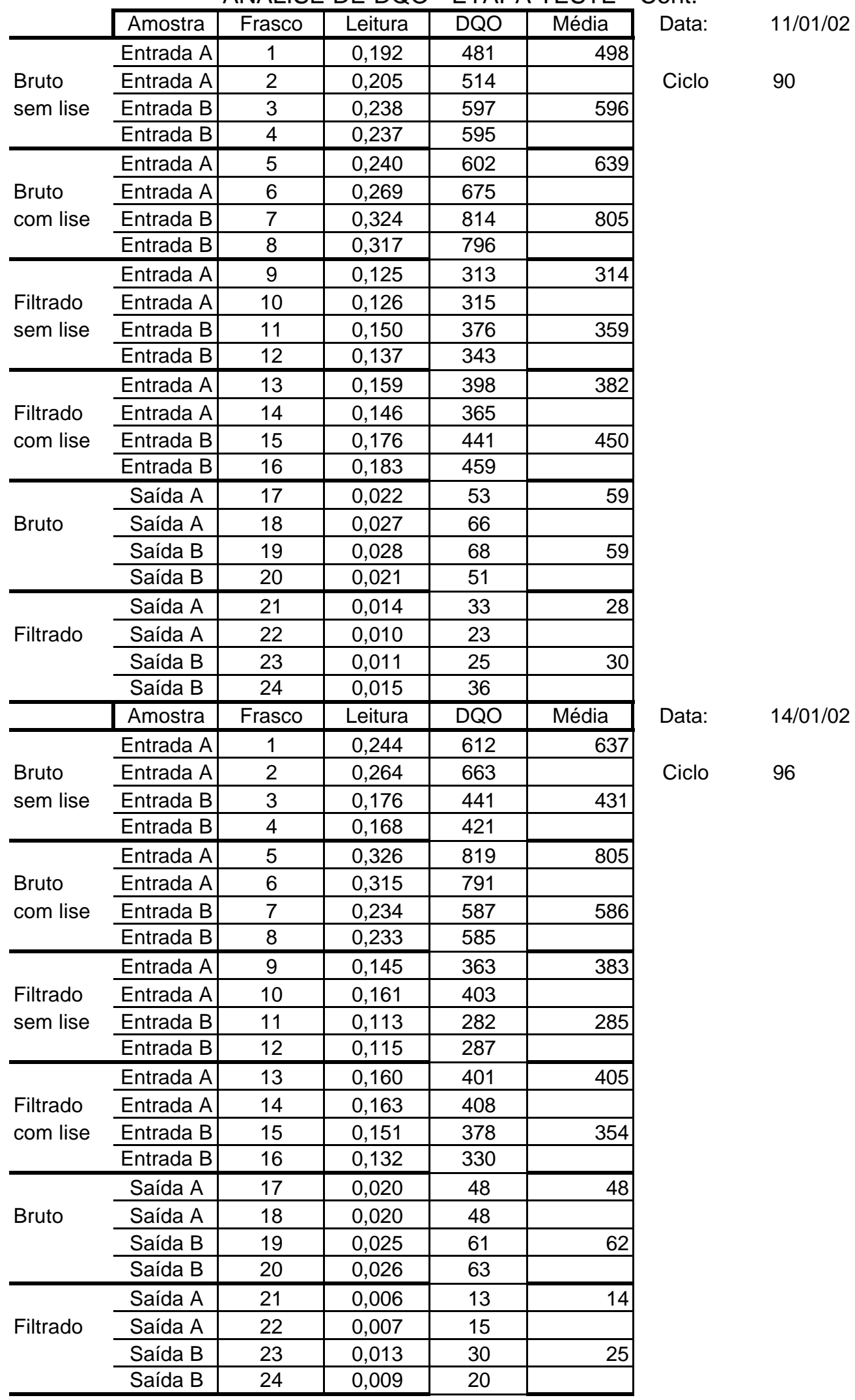


ANALISE DE DQO - ETAPA TESTE - Cont.

\begin{tabular}{|c|c|c|c|c|c|c|c|}
\hline & Amostra & Frasco & Leitura & DQO & Média & Data: & $21 / 01 / 02$ \\
\hline \multirow{4}{*}{$\begin{array}{l}\text { Bruto } \\
\text { sem lise }\end{array}$} & Entrada $\mathrm{A}$ & 1 & 0,163 & 408 & 389 & \multirow{24}{*}{ Ciclo } & \multirow{24}{*}{110} \\
\hline & Entrada $\mathrm{A}$ & 2 & 0,148 & 371 & & & \\
\hline & Entrada B & 3 & 0,165 & 413 & 455 & & \\
\hline & Entrada B & 4 & 0,198 & 496 & & & \\
\hline \multirow{4}{*}{$\begin{array}{l}\text { Bruto } \\
\text { com lise }\end{array}$} & Entrada A & 5 & 0,257 & 645 & 678 & & \\
\hline & Entrada $\mathrm{A}$ & 6 & 0,283 & 711 & & & \\
\hline & Entrada B & 7 & 0,266 & 668 & 601 & & \\
\hline & Entrada B & 8 & 0,213 & 534 & & & \\
\hline \multirow{4}{*}{$\begin{array}{l}\text { Filtrado } \\
\text { sem lise }\end{array}$} & Entrada $\mathrm{A}$ & 9 & 0,106 & 265 & 245 & & \\
\hline & Entrada A & 10 & 0,090 & 224 & & & \\
\hline & Entrada B & 11 & 0,123 & 308 & 294 & & \\
\hline & Entrada B & 12 & 0,112 & 280 & & & \\
\hline \multirow{4}{*}{$\begin{array}{l}\text { Filtrado } \\
\text { com lise }\end{array}$} & Entrada A & 13 & 0,124 & 310 & 297 & & \\
\hline & Entrada $\mathrm{A}$ & 14 & 0,114 & 285 & & & \\
\hline & Entrada B & 15 & 0,137 & 343 & 296 & & \\
\hline & Entrada B & 16 & 0,100 & 250 & & & \\
\hline \multirow{4}{*}{ Bruto } & Saída A & 17 & 0,013 & 30 & 57 & & \\
\hline & Saída A & 18 & 0,034 & 83 & & & \\
\hline & Saída B & 19 & 0,028 & 68 & 68 & & \\
\hline & Saída B & 20 & 0,028 & 68 & & & \\
\hline \multirow{5}{*}{ Filtrado } & Saída A & 21 & 0,014 & 33 & 33 & & \\
\hline & Saída A & 22 & 0,014 & 33 & & & \\
\hline & Saída B & 23 & 0,025 & 61 & 57 & & \\
\hline & Saída B & 24 & 0,022 & 53 & & & \\
\hline & Amostra & Frasco & Leitura & DQO & Média & \multirow[t]{2}{*}{ Data: } & \multirow[t]{2}{*}{$24 / 01 / 02$} \\
\hline \multirow{4}{*}{$\begin{array}{l}\text { Bruto } \\
\text { sem lise }\end{array}$} & Entrada A & 1 & 0,200 & 501 & 523 & & \\
\hline & Entrada $\mathrm{A}$ & 2 & 0,217 & 544 & & \multirow[t]{23}{*}{ Ciclo } & \multirow[t]{23}{*}{116} \\
\hline & Entrada B & 3 & 0,235 & 590 & 651 & & \\
\hline & Entrada B & 4 & 0,284 & 713 & & & \\
\hline \multirow{4}{*}{$\begin{array}{l}\text { Bruto } \\
\text { com lise }\end{array}$} & Entrada A & 5 & 0,316 & 794 & 804 & & \\
\hline & Entrada A & 6 & 0,324 & 814 & & & \\
\hline & Entrada B & 7 & 0,284 & 713 & 795 & & \\
\hline & Entrada B & 8 & 0,349 & 877 & & & \\
\hline \multirow{4}{*}{$\begin{array}{l}\text { Filtrado } \\
\text { sem lise }\end{array}$} & Entrada A & 9 & 0,137 & 343 & 347 & & \\
\hline & Entrada A & 10 & 0,140 & 350 & & & \\
\hline & Entrada B & 11 & 0,141 & 353 & 364 & & \\
\hline & Entrada B & 12 & 0,150 & 376 & & & \\
\hline \multirow{4}{*}{$\begin{array}{l}\text { Filtrado } \\
\text { com lise }\end{array}$} & Entrada $\mathrm{A}$ & 13 & 0,144 & 360 & 365 & & \\
\hline & Entrada $\mathrm{A}$ & 14 & 0,148 & 371 & & & \\
\hline & Entrada B & 15 & 0,166 & 416 & 413 & & \\
\hline & Entrada B & 16 & 0,164 & 411 & & & \\
\hline \multirow{4}{*}{ Bruto } & Saída A & 17 & 0,019 & 46 & 46 & & \\
\hline & Saída A & 18 & 0,019 & 46 & & & \\
\hline & Saída B & 19 & 0,023 & 56 & 54 & & \\
\hline & Saída B & 20 & 0,022 & 53 & & & \\
\hline \multirow{4}{*}{ Filtrado } & Saída A & 21 & 0,013 & 30 & 32 & & \\
\hline & Saída A & 22 & 0,014 & 33 & & & \\
\hline & Saída B & 23 & 0,014 & 33 & 33 & & \\
\hline & Saída B & 24 & 0,014 & 33 & & & \\
\hline
\end{tabular}


ANALISE DE DQO - ETAPA TESTE - Cont.

\begin{tabular}{|c|c|c|c|c|c|c|c|}
\hline & Amostra & Frasco & Leitura & DQO & Média & Data: & $28 / 01 / 02$ \\
\hline \multirow{4}{*}{$\begin{array}{l}\text { Bruto } \\
\text { sem lise }\end{array}$} & Entrada A & 1 & 0,220 & 552 & 562 & \multirow{24}{*}{ Ciclo } & \multirow{24}{*}{124} \\
\hline & Entrada $\mathrm{A}$ & 2 & 0,228 & 572 & & & \\
\hline & Entrada B & 3 & 0,240 & 602 & 602 & & \\
\hline & Entrada B & 4 & 0,240 & 602 & & & \\
\hline \multirow{4}{*}{$\begin{array}{l}\text { Bruto } \\
\text { com lise }\end{array}$} & Entrada A & 5 & 0,298 & 748 & 779 & & \\
\hline & Entrada $\mathrm{A}$ & 6 & 0,322 & 809 & & & \\
\hline & Entrada B & 7 & 0,289 & 726 & 740 & & \\
\hline & Entrada B & 8 & 0,300 & 753 & & & \\
\hline \multirow{4}{*}{$\begin{array}{l}\text { Filtrado } \\
\text { sem lise }\end{array}$} & Entrada $\mathrm{A}$ & 9 & 0,127 & 318 & 325 & & \\
\hline & Entrada A & 10 & 0,133 & 333 & & & \\
\hline & Entrada B & 11 & 0,144 & 360 & 358 & & \\
\hline & Entrada B & 12 & 0,142 & 355 & & & \\
\hline \multirow{4}{*}{$\begin{array}{l}\text { Filtrado } \\
\text { com lise }\end{array}$} & Entrada A & 13 & 0,142 & 355 & 354 & & \\
\hline & Entrada $\mathrm{A}$ & 14 & 0,141 & 353 & & & \\
\hline & Entrada B & 15 & 0,160 & 401 & 405 & & \\
\hline & Entrada B & 16 & 0,163 & 408 & & & \\
\hline \multirow{4}{*}{ Bruto } & Saída A & 17 & 0,039 & 96 & 85 & & \\
\hline & Saída A & 18 & 0,030 & 73 & & & \\
\hline & Saída B & 19 & 0,035 & 86 & 85 & & \\
\hline & Saída B & 20 & 0,034 & 83 & & & \\
\hline \multirow{5}{*}{ Filtrado } & Saída A & 21 & 0,011 & 25 & 23 & & \\
\hline & Saída A & 22 & 0,009 & 20 & & & \\
\hline & Saída B & 23 & 0,012 & 28 & 28 & & \\
\hline & Saída B & 24 & 0,012 & 28 & & & \\
\hline & Amostra & Frasco & Leitura & DQO & Média & \multirow[t]{2}{*}{ Data: } & \multirow[t]{2}{*}{$04 / 02 / 02$} \\
\hline \multirow{4}{*}{$\begin{array}{l}\text { Bruto } \\
\text { sem lise }\end{array}$} & Entrada A & 1 & & 596 & 600 & & \\
\hline & Entrada $\mathrm{A}$ & 2 & & 604 & & \multirow[t]{23}{*}{ Ciclo } & \multirow[t]{23}{*}{138} \\
\hline & Entrada B & 3 & & 663 & 667 & & \\
\hline & Entrada B & 4 & & 670 & & & \\
\hline \multirow{4}{*}{$\begin{array}{l}\text { Bruto } \\
\text { com lise }\end{array}$} & Entrada A & 5 & & 800 & 779 & & \\
\hline & Entrada A & 6 & & 758 & & & \\
\hline & Entrada B & 7 & 0,341 & 857 & 848 & & \\
\hline & Entrada B & 8 & 0,334 & 839 & & & \\
\hline \multirow{4}{*}{$\begin{array}{l}\text { Filtrado } \\
\text { sem lise }\end{array}$} & Entrada A & 9 & & 439 & 464 & & \\
\hline & Entrada A & 10 & & 489 & & & \\
\hline & Entrada B & 11 & & 476 & 478 & & \\
\hline & Entrada B & 12 & & 479 & & & \\
\hline \multirow{4}{*}{$\begin{array}{l}\text { Filtrado } \\
\text { com lise }\end{array}$} & Entrada $\mathrm{A}$ & 13 & & 474 & 477 & & \\
\hline & Entrada $\mathrm{A}$ & 14 & & 480 & & & \\
\hline & Entrada B & 15 & & 512 & 511 & & \\
\hline & Entrada B & 16 & & 510 & & & \\
\hline \multirow{4}{*}{ Bruto } & Saída A & 17 & & 77 & 79 & & \\
\hline & Saída A & 18 & & 81 & & & \\
\hline & Saída B & 19 & & 67 & 67 & & \\
\hline & Saída B & 20 & & 67 & & & \\
\hline \multirow{4}{*}{ Filtrado } & Saída A & 21 & & 28 & 28 & & \\
\hline & Saída A & 22 & & 28 & & & \\
\hline & Saída B & 23 & & 23 & 23 & & \\
\hline & Saída B & 24 & & 23 & & & \\
\hline
\end{tabular}


ANALISE DE DQO - ETAPA TESTE - Cont.

\begin{tabular}{|c|c|c|c|c|c|c|c|}
\hline & Amostra & Frasco & Leitura & DQO & Média & Data: & 06/02/02 \\
\hline \multirow{4}{*}{$\begin{array}{l}\text { Bruto } \\
\text { sem lise }\end{array}$} & Entrada A & 1 & & 748 & 780 & \multirow{24}{*}{ Ciclo } & \multirow{24}{*}{142} \\
\hline & Entrada $\mathrm{A}$ & 2 & 0,323 & 811 & & & \\
\hline & Entrada B & 3 & & 640 & 687 & & \\
\hline & Entrada B & 4 & & 734 & & & \\
\hline \multirow{4}{*}{$\begin{array}{l}\text { Bruto } \\
\text { com lise }\end{array}$} & Entrada A & 5 & 0,390 & 980 & 988 & & \\
\hline & Entrada $\mathrm{A}$ & 6 & 0,396 & 995 & & & \\
\hline & Entrada B & 7 & 0,367 & 922 & 916 & & \\
\hline & Entrada B & 8 & 0,362 & 910 & & & \\
\hline \multirow{4}{*}{$\begin{array}{l}\text { Filtrado } \\
\text { sem lise }\end{array}$} & Entrada $\mathrm{A}$ & 9 & & 573 & 568 & & \\
\hline & Entrada A & 10 & & 563 & & & \\
\hline & Entrada B & 11 & & 483 & 485 & & \\
\hline & Entrada B & 12 & & 487 & & & \\
\hline \multirow{4}{*}{$\begin{array}{l}\text { Filtrado } \\
\text { com lise }\end{array}$} & Entrada A & 13 & & 520 & 538 & & \\
\hline & Entrada $\mathrm{A}$ & 14 & & 555 & & & \\
\hline & Entrada B & 15 & & 518 & 518 & & \\
\hline & Entrada B & 16 & & 518 & & & \\
\hline \multirow{4}{*}{ Bruto } & Saída A & 17 & & 39 & 47 & & \\
\hline & Saída A & 18 & & 54 & & & \\
\hline & Saída B & 19 & & 35 & 45 & & \\
\hline & Saída B & 20 & & 55 & & & \\
\hline \multirow{5}{*}{ Filtrado } & Saída A & 21 & & 28 & 34 & & \\
\hline & Saída A & 22 & & 39 & & & \\
\hline & Saída B & 23 & & 30 & 32 & & \\
\hline & Saída B & 24 & & 34 & & & \\
\hline & Amostra & Frasco & Leitura & $\overline{D Q O}$ & Média & \multirow[t]{2}{*}{ Data: } & \multirow[t]{2}{*}{$18 / 02 / 02$} \\
\hline \multirow{4}{*}{$\begin{array}{l}\text { Bruto } \\
\text { sem lise }\end{array}$} & Entrada A & 1 & & 604 & 608 & & \\
\hline & Entrada $\mathrm{A}$ & 2 & 0,323 & 612 & & \multirow[t]{23}{*}{ Ciclo } & \multirow[t]{23}{*}{166} \\
\hline & Entrada B & 3 & & 618 & 591 & & \\
\hline & Entrada B & 4 & & 563 & & & \\
\hline \multirow{4}{*}{$\begin{array}{l}\text { Bruto } \\
\text { com lise }\end{array}$} & Entrada A & 5 & 0,349 & 877 & 872 & & \\
\hline & Entrada A & 6 & 0,345 & 867 & & & \\
\hline & Entrada B & 7 & 0,347 & 872 & 845 & & \\
\hline & Entrada B & 8 & 0,326 & 819 & & & \\
\hline \multirow{4}{*}{$\begin{array}{l}\text { Filtrado } \\
\text { sem lise }\end{array}$} & Entrada A & 9 & & 453 & 456 & & \\
\hline & Entrada A & 10 & & 458 & & & \\
\hline & Entrada B & 11 & & 432 & 418 & & \\
\hline & Entrada B & 12 & & 403 & & & \\
\hline \multirow{4}{*}{$\begin{array}{l}\text { Filtrado } \\
\text { com lise }\end{array}$} & Entrada $\mathrm{A}$ & 13 & & 432 & 432 & & \\
\hline & Entrada $\mathrm{A}$ & 14 & & 432 & & & \\
\hline & Entrada B & 15 & & 424 & 430 & & \\
\hline & Entrada B & 16 & & 436 & & & \\
\hline \multirow{4}{*}{ Bruto } & Saída A & 17 & & 40 & 39 & & \\
\hline & Saída A & 18 & & 38 & & & \\
\hline & Saída B & 19 & & 66 & 63 & & \\
\hline & Saída B & 20 & & 59 & & & \\
\hline \multirow{4}{*}{ Filtrado } & Saída A & 21 & & 27 & 22 & & \\
\hline & Saída A & 22 & & 17 & & & \\
\hline & Saída B & 23 & & 18 & 21 & & \\
\hline & Saída B & 24 & & 23 & & & \\
\hline
\end{tabular}


ANALISE DE DQO - ETAPA TESTE - Cont.

\begin{tabular}{|c|c|c|c|c|c|}
\hline & Amostra & Frasco & Leitura & $\mathrm{DQO}$ & Média \\
\hline \multirow{4}{*}{$\begin{array}{l}\text { Bruto } \\
\text { sem lise }\end{array}$} & Entrada A & 1 & & 489 & 511 \\
\hline & Entrada A & 2 & & 533 & \\
\hline & Entrada B & 3 & & 569 & 557 \\
\hline & Entrada B & 4 & & 545 & \\
\hline \multirow{4}{*}{$\begin{array}{l}\text { Bruto } \\
\text { com lise }\end{array}$} & Entrada A & 5 & 0,342 & 859 & 883 \\
\hline & Entrada A & 6 & 0,361 & 907 & \\
\hline & Entrada B & 7 & 0,284 & 713 & 811 \\
\hline & Entrada B & 8 & 0,362 & 910 & \\
\hline \multirow{4}{*}{$\begin{array}{l}\text { Filtrado } \\
\text { sem lise }\end{array}$} & Entrada A & 9 & & 296 & 298 \\
\hline & Entrada A & 10 & & 300 & \\
\hline & Entrada B & 11 & & 329 & 334 \\
\hline & Entrada B & 12 & & 338 & \\
\hline \multirow{4}{*}{$\begin{array}{l}\text { Filtrado } \\
\text { com lise }\end{array}$} & Entrada A & 13 & & 323 & 317 \\
\hline & Entrada A & 14 & & 310 & \\
\hline & Entrada B & 15 & & 359 & 362 \\
\hline & Entrada B & 16 & & 364 & \\
\hline \multirow{4}{*}{ Bruto } & Saída A & 17 & & 36 & 40 \\
\hline & Saída A & 18 & & 43 & \\
\hline & Saída B & 19 & & 56 & 45 \\
\hline & Saída B & 20 & & 33 & \\
\hline \multirow{4}{*}{ Filtrado } & Saída A & 21 & & 24 & 26 \\
\hline & Saída A & 22 & & 27 & \\
\hline & Saída B & 23 & & 22 & 21 \\
\hline & Saída B & 24 & & 20 & \\
\hline
\end{tabular}

Data: 20/02/02

Ciclo $\quad 170$ 
ANÁLISE DE DQO - ETAPA TESTE - RESUMO

\begin{tabular}{|c|c|c|c|c|c|c|c|c|c|c|c|c|c|c|c|c|c|}
\hline \multirow{3}{*}{ DATA } & \multirow[b]{3}{*}{ Tempo } & & \multicolumn{4}{|c|}{ Relaçao filt/total } \\
\hline & & \multicolumn{2}{|c|}{ Bruto sem lise } & \multicolumn{2}{|c|}{ Bruto com lise } & \multicolumn{2}{|c|}{ Filtrado sem lise } & \multicolumn{2}{|c|}{ Filtrado com lise } & \multicolumn{2}{|c|}{ Bruto } & \multicolumn{2}{|c|}{ Filtrado } & \multicolumn{2}{|c|}{ Reator A } & \multicolumn{2}{|c|}{ Reator B } \\
\hline & & Entrada $\mathrm{A}$ & Entrada B & Entrada A & Entrada B & Entrada A & Entrada B & Entrada A & Entrada B & Saída A & Saída B & Saída A & Saída B & Afluente A & Efluente $\mathrm{A}$ & \begin{tabular}{|l|} 
Afluente B \\
\end{tabular} & Efluente B \\
\hline $27 / 11 / 01$ & 1 & 472 & 560 & 514 & 600 & 279 & 307 & 237 & 274 & 48 & 36 & 19 & 16 & \begin{tabular}{|l|}
46,1 \\
\end{tabular} & 38,6 & 45,6 & 44,1 \\
\hline $27 / 11 / 01$ & 2 & 543 & 529 & 670 & 554 & 329 & 310 & 338 & 333 & 54 & 44 & 23 & 20 & 50,5 & 42,3 & 60,1 & 45,2 \\
\hline $28 / 12 / 01$ & 3 & 689 & 508 & 767 & 670 & 376 & 288 & 388 & 319 & 79 & 66 & 46 & 34 & 50,6 & 57,5 & 47,7 & 50,9 \\
\hline $1 / 12 / 01$ & 8 & 701 & 561 & 840 & 778 & 430 & 350 & 377 & 337 & 48 & 29 & 46 & 51 & 44,9 & 94,4 & 43,3 & \\
\hline $4 / 12 / 01$ & 14 & 689 & 508 & 767 & 670 & 376 & 288 & 388 & 319 & 79 & 66 & 46 & 34 & 50,6 & 57,5 & 47,7 & 50,9 \\
\hline 9/12/01 & 24 & 701 & 561 & 840 & 778 & 430 & 350 & 377 & 337 & 48 & 29 & 46 & 51 & 44,9 & 94,4 & 43,3 & \\
\hline $12 / 12 / 01$ & 30 & 701 & 554 & 836 & 731 & 392 & 336 & 303 & 313 & 28 & 66 & 28 & 16 & 36,3 & & 42,8 & 24,2 \\
\hline $15 / 12 / 01$ & 36 & 456 & 581 & 660 & 732 & 318 & 389 & 247 & 349 & 53 & 96 & 24 & 22 & 37,4 & 45,5 & 47,7 & 22,6 \\
\hline $17 / 12 / 01$ & 40 & 445 & 607 & 685 & 756 & 305 & 309 & 329 & 354 & 63 & 57 & 54 & 36 & 48,0 & 86,1 & 46,9 & 62,4 \\
\hline $19 / 12 / 01$ & 44 & 544 & 456 & 622 & 614 & 354 & 260 & 428 & 309 & 54 & 80 & 18 & 18 & 68,8 & 32,9 & 50,3 & 22,5 \\
\hline $28 / 12 / 01$ & 62 & 562 & 602 & 779 & 740 & 325 & 358 & 354 & 405 & 85 & 85 & 23 & 28 & 45,5 & 27,1 & 54,7 & 33,0 \\
\hline $30 / 12 / 01$ & 66 & 534 & 559 & 605 & 669 & 262 & 335 & 301 & 360 & 77 & 96 & 49 & 32 & 49,8 & 64,1 & 53,9 & 33,1 \\
\hline $03 / 01 / 02$ & 74 & 534 & 427 & 651 & 590 & 297 & 274 & 325 & 274 & 107 & 86 & 38 & 42 & 49,9 & 35,5 & 46,4 & 48,7 \\
\hline $7 / 1 / 02$ & 82 & 558 & 524 & 756 & 639 & 374 & 321 & 358 & 323 & 59 & 96 & 33 & 27 & 47,4 & 55,5 & 50,5 & 27,8 \\
\hline $11 / 01 / 02$ & 90 & 498 & 596 & 639 & 805 & 314 & 359 & 382 & 450 & 59 & 59 & 28 & 30 & 59,8 & 47,0 & 55,9 & 51,3 \\
\hline $14 / 01 / 02$ & 96 & 637 & 431 & 805 & 586 & 383 & 285 & 405 & 354 & 48 & 62 & 14 & 25 & 50,3 & 29,3 & 60,4 & 41,1 \\
\hline $21 / 01 / 02$ & 110 & 389 & 455 & 678 & 601 & 245 & 294 & 297 & 296 & 57 & 68 & 33 & 57 & 43,9 & 58,0 & 49,3 & 83,4 \\
\hline $24 / 01 / 02$ & 116 & 523 & 651 & 804 & 795 & 347 & 364 & 365 & 413 & 46 & 54 & 32 & 33 & 45,5 & 69,6 & 52,0 & 60,7 \\
\hline $28 / 01 / 02$ & 124 & 562 & 602 & 779 & 740 & 325 & 358 & 354 & 405 & 85 & 85 & 23 & 28 & 45,5 & 27,1 & 54,7 & 33,0 \\
\hline $04 / 02 / 02$ & 138 & 600 & 667 & 779 & 848 & 464 & 478 & 477 & 511 & 79 & 67 & 28 & 23 & 61,2 & 35,4 & 60,3 & 34,3 \\
\hline $06 / 02 / 02$ & 142 & 780 & 687 & 988 & 916 & 568 & 485 & 538 & 518 & 47 & 45 & 34 & 32 & 54,4 & 72,0 & 56,6 & 71,1 \\
\hline $18 / 02 / 02$ & 166 & 608 & 591 & 872 & 845 & 456 & 418 & 432 & 430 & 39 & 63 & 22 & 21 & 49,6 & 56,4 & 50,9 & 32,8 \\
\hline $20 / 02 / 02$ & 170 & 511 & 557 & 883 & 811 & 298 & 334 & 317 & 362 & 40 & 45 & 26 & 21 & 35,8 & 64,6 & 44,6 & 47,2 \\
\hline & media & 576 & 555 & 749 & 716 & 359 & 341 & 362 & 363 & 60 & 64 & 32 & 30 & 49 & 54 & 51 & 44 \\
\hline & desvio & 99 & 70 & 109 & 99 & 75 & 58 & 68 & 67 & 19 & 20 & 11 & 11 & 8 & 20 & 6 & 16 \\
\hline
\end{tabular}




\section{ANÁLISE DE SÓLIDOS - ETAPA CONTROLE}

\begin{tabular}{|c|c|c|c|c|c|c|c|c|}
\hline Tempo & Amostra & Volume & $\mathrm{PO}$ & $\mathrm{P} 1$ & $\mathrm{P} 2$ & Totais & Fixos & Voláteis \\
\hline \multirow{8}{*}{0} & Entrada A & 50 & 24,29157 & 24,3006 & 24,29362 & 181 & 41 & 140 \\
\hline & Entrada B & 50 & 29,08916 & 29,09791 & 29,09153 & 175 & 47 & 128 \\
\hline & Saída A & 50 & 24,66521 & 24,66581 & 24,665 & 12 & 0 & 12 \\
\hline & Saída B & 50 & 21,65128 & 21,65574 & 21,65279 & 89 & 30 & 59 \\
\hline & Tanque $\mathrm{A}$ & 25 & 26,20418 & 26,26499 & 26,2127 & 2432 & 341 & 2092 \\
\hline & Tanque B & 25 & 23,12468 & 23,1926 & 23,13463 & 2717 & 398 & 2319 \\
\hline & Tanque $\mathrm{A}$ & 25 & 77,91148 & 77,9837 & 77,9296 & 2889 & 725 & 2164 \\
\hline & Tanque $\mathrm{B}$ & 25 & 82,8553 & 82,9346 & 82,8679 & 3172 & 504 & 2668 \\
\hline \multirow{8}{*}{16} & Amostra & Volume & $\mathrm{P} 0$ & $\mathrm{P} 1$ & $\mathrm{P} 2$ & Totais & Fixos & Voláteis \\
\hline & Entrada A & 50 & 19,91321 & 19,9175 & 19,9126 & 86 & 0 & 86 \\
\hline & Entrada B & 50 & 22,45097 & 22,461 & 22,4504 & 201 & 0 & 201 \\
\hline & Saída A & 50 & 22,54181 & 22,5434 & 22,541 & 32 & 0 & 32 \\
\hline & Saída B & 50 & 24,0701 & 24,071 & 24,06835 & 18 & 0 & 18 \\
\hline & Tanque A & 19 & 83,5714 & 83,6189 & 83,5838 & 2500 & 653 & 1847 \\
\hline & Tanque B & 19 & 82,4686 & 82,5052 & 82,4713 & 1926 & 142 & 1784 \\
\hline & Tanque $\mathrm{A}$ & & & & & & & \\
\hline \multirow{13}{*}{28} & Tanque $\mathrm{B}$ & & & & & & & \\
\hline & Amostra & Volume & P0 & P1 & P2 & Totais & Fixos & Voláteis \\
\hline & Entrada A & 50 & 22,4501 & 22,4543 & 22,45117 & 84 & 21 & 63 \\
\hline & Entrada B & 50 & 22,51642 & 22,5195 & 22,51542 & 62 & 0 & 62 \\
\hline & Saída A & 50 & 22,64616 & 22,6477 & 22,64638 & 31 & 4 & 26 \\
\hline & Saída B & 50 & 20,13952 & 20,1412 & 20,13979 & 34 & 5 & 28 \\
\hline & Tanque A & 15 & 19,92082 & 19,9543 & 19,92686 & 2232 & 403 & 1829 \\
\hline & Tanque B & 15 & 22,98245 & 23,02 & 22,98905 & 2503 & 440 & 2063 \\
\hline & Tanque A & 50 & 76,30136 & 76,44509 & 76,33522 & 2875 & 677 & 2197 \\
\hline & Tanque $\mathrm{B}$ & 50 & 51,67797 & 51,8429 & 51,71656 & 3299 & 772 & 2527 \\
\hline & Amostra & Volume & P0 & $\mathrm{P} 1$ & P2 & Totais & Fixos & Voláteis \\
\hline & Entrada A & 50 & 76,60227 & 76,60425 & 76,602 & 40 & 0 & 40 \\
\hline & Entrada B & 50 & 23,47554 & 23,4804 & 23,47631 & 97 & 15 & 82 \\
\hline \multirow[t]{9}{*}{38} & Saída A & 50 & 22,70788 & 22,71038 & 22,70878 & 50 & 18 & 32 \\
\hline & Saída B & 50 & 79,14546 & 79,14643 & 79,14551 & 19 & 1 & 18 \\
\hline & Tanque A & 15 & 54,95 & 54,98565 & 54,95594 & 2377 & 396 & 1981 \\
\hline & Tanque B & 15 & 76,15604 & 76,18709 & 76,16139 & 2070 & 357 & 1713 \\
\hline & Tanque $\mathrm{A}$ & 50 & 61,01829 & 61,18358 & 61,0535 & 3306 & 704 & 2602 \\
\hline & Tanque $\mathrm{B}$ & 50 & 54,01353 & 54,17863 & 54,05401 & 3302 & 810 & 2492 \\
\hline & Amostra & Volume & P0 & $\mathrm{P} 1$ & P2 & Totais & Fixos & Voláteis \\
\hline & Entrada A & 90 & 20,1396 & 20,14662 & 20,13961 & 78 & 0 & 78 \\
\hline & Entrada B & 90 & 22,6444 & 22,65057 & 22,64458 & 69 & 2 & 67 \\
\hline \multirow[t]{6}{*}{42} & Saída A & 90 & 22,4501 & 22,45323 & 22,45042 & 35 & 4 & 31 \\
\hline & Saída B & 90 & 22,9842 & 22,98825 & 22,98485 & 45 & 7 & 38 \\
\hline & Tanque $\mathrm{A}$ & 19 & 22,5164 & 22,56076 & 22,52345 & 2335 & 371 & 1964 \\
\hline & Tanque B & 19 & 19,922 & 19,96443 & 19,92931 & 2233 & 385 & 1848 \\
\hline & Tanque A & 80 & 92,0155 & 92,2309 & 92,0699 & 2693 & 680 & 2013 \\
\hline & Tanque B & 80 & 89,1677 & 89,3795 & 89,223 & 2647 & 691 & 1956 \\
\hline
\end{tabular}


ANÁLISE DE SÓLIDOS - ETAPA CONTROLE - Cont.

\begin{tabular}{|c|c|c|c|c|c|c|c|c|}
\hline \multirow[t]{3}{*}{ Tempo } & Amostra & Volume & P0 & $\mathrm{P} 1$ & $\mathrm{P} 2$ & Totais & Fixos & Voláteis \\
\hline & Entrada A & 50 & 22,7071 & 22,71184 & 22,70748 & 95 & 8 & 87 \\
\hline & Entrada B & 50 & 23,47683 & 23,48118 & 23,47692 & 87 & 2 & 85 \\
\hline \multirow[t]{9}{*}{52} & Saída A & 50 & 54,9472 & 54,9486 & 54,94769 & 28 & 10 & 18 \\
\hline & Saída B & 50 & 76,15438 & 76,15635 & 76,15506 & 39 & 14 & 26 \\
\hline & Tanque $\mathrm{A}$ & 19 & 76,60313 & 76,64278 & 76,60761 & 2087 & 236 & 1851 \\
\hline & Tanque $\mathrm{B}$ & 19 & 79,14436 & 79,17821 & 79,14614 & 1782 & 94 & 1688 \\
\hline & Tanque A & 50 & 61,01048 & 61,15119 & 61,04601 & 2814 & 711 & 2104 \\
\hline & Tanque B & 50 & 54,01183 & 54,13789 & 54,03865 & 2521 & 536 & 1985 \\
\hline & Amostra & Volume & P0 & P1 & P2 & Totais & Fixos & Voláteis \\
\hline & Entrada A & 90 & 22,45045 & 22,4571 & 22,4509 & 74 & 5 & 69 \\
\hline & Entrada B & 90 & 22,51582 & 22,52213 & 22,5163 & 70 & 5 & 65 \\
\hline \multirow[t]{8}{*}{56} & Saída A & 90 & 20,14151 & 20,144 & 20,1421 & 28 & 7 & 21 \\
\hline & Saída B & 90 & 22,64516 & 22,64779 & 22,645 & 29 & 0 & 29 \\
\hline & Tanque A & 19 & 22,9827 & 23,02516 & 22,99 & 2235 & 384 & 1851 \\
\hline & Tanque $\mathrm{B}$ & 19 & 19,9198 & 19,95293 & 19,9245 & 1744 & 247 & 1496 \\
\hline & Tanque A & 55 & 92,0171 & 92,1715 & 92,0585 & 2807 & 753 & 2055 \\
\hline & Tanque $\mathrm{B}$ & 90 & 89,1706 & 89,3775 & 89,2243 & 2299 & 597 & 1702 \\
\hline & Amostra & Volume & P0 & P1 & P2 & Totais & Fixos & Voláteis \\
\hline & Entrada A & 80 & 0,0881 & 0,09425 & 0,08855 & 77 & 6 & 71 \\
\hline \multirow[t]{10}{*}{68} & Entrada B & 100 & 0,0885 & 0,09522 & 0,08818 & 67 & 0 & 67 \\
\hline & Saída A & 90 & 0,0886 & 0,09522 & 0,08892 & 74 & 4 & 70 \\
\hline & Saída B & 90 & 0,0874 & 0,09016 & 0,08756 & 31 & 2 & 29 \\
\hline & Tanque A & 19 & 0,089 & 0,13169 & 0,09641 & 2247 & 390 & 1857 \\
\hline & Tanque B & 19 & 0,0882 & 0,12666 & 0,09295 & 2024 & 250 & 1774 \\
\hline & Tanque A & 60 & 54,0147 & 54,19457 & 54,0522 & 2998 & 625 & 2373 \\
\hline & Tanque B & 60 & 61,0209 & 61,1858 & 61,0565 & 2748 & 593 & 2155 \\
\hline & Amostra & Volume & P0 & $\mathrm{P} 1$ & P2 & Totais & Fixos & Voláteis \\
\hline & Entrada A & 80 & 0,08757 & 0,09342 & 0,08767 & 73 & 1 & 72 \\
\hline & Entrada B & 80 & 0,08809 & 0,09399 & 0,08832 & 74 & 3 & 71 \\
\hline \multirow[t]{9}{*}{72} & Saída A & 80 & 0,08797 & 0,08924 & 0,08822 & 16 & 3 & 13 \\
\hline & Saída B & 80 & 0,08844 & 0,0902 & 0,08868 & 22 & 3 & 19 \\
\hline & Tanque A & 19 & 0,08683 & 0,1248 & 0,09348 & 1998 & 350 & 1648 \\
\hline & Tanque B & 19 & 0,08641 & 0,12724 & 0,09211 & 2149 & 300 & 1849 \\
\hline & Tanque $\mathrm{A}$ & 70 & 89,0325 & 89,2422 & 89,0903 & 2996 & 826 & 2170 \\
\hline & Tanque $\mathrm{B}$ & 80 & 82,4726 & 82,6981 & 82,5326 & 2819 & 750 & 2069 \\
\hline & Amostra & Volume & P0 & $\mathrm{P} 1$ & P2 & Totais & Fixos & Voláteis \\
\hline & Entrada A & 80 & 0,08787 & 0,09419 & 0,0881 & 79 & 3 & 76 \\
\hline & Entrada B & 80 & 0,08715 & 0,09474 & 0,08743 & 95 & 3 & 91 \\
\hline \multirow[t]{9}{*}{96} & Saída A & 80 & 0,08896 & 0,09042 & 0,08923 & 18 & 3 & 15 \\
\hline & Saída B & 80 & 0,08779 & 0,08949 & 0,08808 & 21 & 4 & 18 \\
\hline & Tanque A & 19 & 0,08872 & 0,12726 & 0,09486 & 2028 & 323 & 1705 \\
\hline & Tanque $\mathrm{B}$ & 19 & 0,08768 & 0,12487 & 0,09347 & 1957 & 305 & 1653 \\
\hline & Tanque $\mathrm{A}$ & 80 & 76,51499 & 76,73886 & 76,569 & 2798 & 675 & 2123 \\
\hline & Tanque B & 80 & 54,86259 & 55,06734 & 54,91312 & 2559 & 632 & 1928 \\
\hline & Amostra & Volume & $\mathrm{P} 0$ & $\mathrm{P} 1$ & P2 & Totais & Fixos & Voláteis \\
\hline & Entrada A & 70 & 0,0896 & 0,0943 & 0,08977 & 67 & 2 & 65 \\
\hline & Entrada B & 70 & & & & 0 & 0 & 0 \\
\hline \multirow[t]{6}{*}{106} & Saída A & 70 & & & & 0 & 0 & 0 \\
\hline & Saída B & 70 & 0,0905 & 0,0928 & 0,0908 & 33 & 4 & 29 \\
\hline & \begin{tabular}{|l|} 
Tanque $\mathrm{A}$ \\
\end{tabular} & 19 & 0,0901 & 0,1234 & 0,09459 & 1753 & 236 & 1516 \\
\hline & Tanque B & 19 & 0,0906 & 0,1321 & 0,09639 & 2184 & 305 & 1879 \\
\hline & Tanque A & 60 & 82,475 & 82,6648 & 82,5302 & 3163 & 920 & 2243 \\
\hline & Tanque $\mathrm{B}$ & 60 & 89,0412 & 89,2491 & 89,0926 & 3465 & 857 & 2608 \\
\hline
\end{tabular}


ANÁLISE DE SÓLIDOS - ETAPA CONTROLE - Cont.

\begin{tabular}{|c|c|c|c|c|c|c|c|c|}
\hline \multirow[t]{2}{*}{ Tempo } & Amostra & Volume & P0 & P1 & $\mathrm{P} 2$ & Totais & Fixos & Voláteis \\
\hline & Entrada A & & & & & \#DIV/0! & \#DIV/0! & \#DIV/0! \\
\hline \multirow[t]{9}{*}{122} & Entrada B & & & & & \#DIV/0! & \#DIV/0! & \#DIV/0! \\
\hline & Saída A & 70 & 0,09081 & 0,0932 & 0,09183 & 34 & 15 & 20 \\
\hline & Saída B & 70 & 0,08837 & 0,0907 & 0,08878 & 33 & 6 & 27 \\
\hline & Tanque A & 19 & 0,09175 & 0,1251 & 0,09635 & 1755 & 242 & 1513 \\
\hline & Tanque B & 19 & 0,08907 & 0,1366 & 0,09726 & 2502 & 431 & 2071 \\
\hline & Tanque $\mathrm{A}$ & 60 & 51,6802 & 51,8911 & 51,7322 & 3515 & 867 & 2648 \\
\hline & Tanque $\mathrm{B}$ & 60 & 54,0162 & 54,2405 & 54,0765 & 3738 & 1005 & 2733 \\
\hline & Amostra & Volume & $\mathrm{P} 0$ & $\mathrm{P} 1$ & P2 & Totais & Fixos & Voláteis \\
\hline & Entrada A & & & & & \#DIV/0! & \#DIV/0! & \#DIV/0! \\
\hline \multirow[t]{9}{*}{138} & Entrada B & & & & & \#DIV/0! & \#DIV/0! & \#DIV/0! \\
\hline & Saída A & 70 & 0,0888 & 0,0932 & 0,09138 & 63 & 37 & 26 \\
\hline & Tanque $\mathrm{A}$ & 19 & 0,08848 & 0,1236 & 0,09356 & 1848 & 267 & 1581 \\
\hline & Tanque B & 19 & 0,09139 & 0,1336 & 0,09888 & 2222 & 394 & 1827 \\
\hline & Tanque $\mathrm{A}$ & 60 & 76,52108 & 76,7121 & 76,57308 & 3184 & 867 & 2317 \\
\hline & Tanque B & 60 & 79,05311 & 79,2475 & 79,1062 & 3240 & 885 & 2355 \\
\hline & Amostra & Volume & $\mathrm{P} 0$ & $\mathrm{P} 1$ & P2 & Totais & Fixos & Voláteis \\
\hline & Entrada A & 70 & 0,09057 & 0,0978 & 0,09295 & 103 & 34 & 69 \\
\hline & Entrada B & & & & & \#DIV/0! & \#DIV/0! & \#DIV/0! \\
\hline \multirow[t]{9}{*}{152} & Saída A & & & & & \#DIV/0! & \#DIV/0! & \#DIV/0! \\
\hline & Saída B & 70 & 0,09081 & 0,0953 & 0,09327 & 64 & 35 & 29 \\
\hline & Tanque A & 19 & 0,08713 & 0,123 & 0,09258 & 1888 & 287 & 1601 \\
\hline & Tanque B & 19 & 0,08844 & 0,126 & 0,09478 & 1977 & 334 & 1643 \\
\hline & Tanque A & 60 & 60,47164 & 60,65169 & 60,51944 & 3001 & 797 & 2204 \\
\hline & Tanque $\mathrm{B}$ & 60 & 68,46194 & 68,65441 & 68,51627 & 3208 & 906 & 2302 \\
\hline & Amostra & Volume & $\mathrm{P} 0$ & $\mathrm{P} 1$ & P2 & Totais & Fixos & Voláteis \\
\hline & Entrada A & & & & & \#DIV/0! & \#DIV/0! & \#DIV/0! \\
\hline & Entrada B & & & & & \#DIV/0! & \#DIV/0! & \#DIV/0! \\
\hline \multirow[t]{9}{*}{166} & Saída A & 70 & 0,09066 & 0,0933 & 0,09244 & 38 & 25 & 12 \\
\hline & Saída B & 70 & 0,09027 & 0,0913 & 0,09053 & 15 & 4 & 11 \\
\hline & Tanque A & 19 & 0,09091 & 0,1261 & 0,09628 & 1852 & 283 & 1569 \\
\hline & Tanque B & 19 & 0,09025 & 0,1371 & 0,09839 & 2466 & 428 & 2037 \\
\hline & Tanque A & 60 & 76,06615 & 76,2386 & 76,11327 & 2874 & 785 & 2089 \\
\hline & Tanque B & 60 & 61,0145 & 61,2296 & 61,06872 & 3585 & 904 & 2681 \\
\hline & Amostra & Volume & $\mathrm{P} 0$ & $\mathrm{P} 1$ & P2 & Totais & Fixos & Voláteis \\
\hline & Entrada A & 100 & 24,41928 & 24,43426 & 24,42021 & 150 & 9 & 140 \\
\hline & Entrada B & 100 & 25,67341 & 25,68384 & 25,67463 & 104 & 12 & 92 \\
\hline \multirow[t]{7}{*}{180} & Saída A & 100 & 22,51998 & 22,52366 & 22,52049 & 37 & 5 & 32 \\
\hline & Saída B & 100 & 23,64212 & 23,64766 & 23,64352 & 55 & 14 & 41 \\
\hline & Tanque A & 19 & 26,7515 & 26,80224 & 26,75911 & 2671 & 401 & 2270 \\
\hline & Tanque B & 19 & 23,1472 & 23,19005 & 23,15566 & 2255 & 445 & 1810 \\
\hline & Tanque A & 80 & 54,0282 & 54,29797 & 54,10316 & 3372 & 937 & 2435 \\
\hline & Tanque B & 85 & 76,31955 & 76,55473 & 76,39012 & 2767 & 830 & 1937 \\
\hline & Entrada A & 80 & 72,3322 & 72,43408 & 72,38622 & 1273 & 675 & 598 \\
\hline \multirow[t]{3}{*}{ totais } & Entrada B & 70 & 61,0272 & 61,10371 & 61,0649 & 1093 & 539 & 554 \\
\hline & Saída A & 70 & 51,7073 & 51,76618 & 51,75228 & 841 & 643 & 199 \\
\hline & Saída B & 70 & 50,7109 & 50,75867 & 50,74626 & 682 & 505 & 177 \\
\hline
\end{tabular}


ANÁLISE DE SÓLIDOS - ETAPA CONTROLE

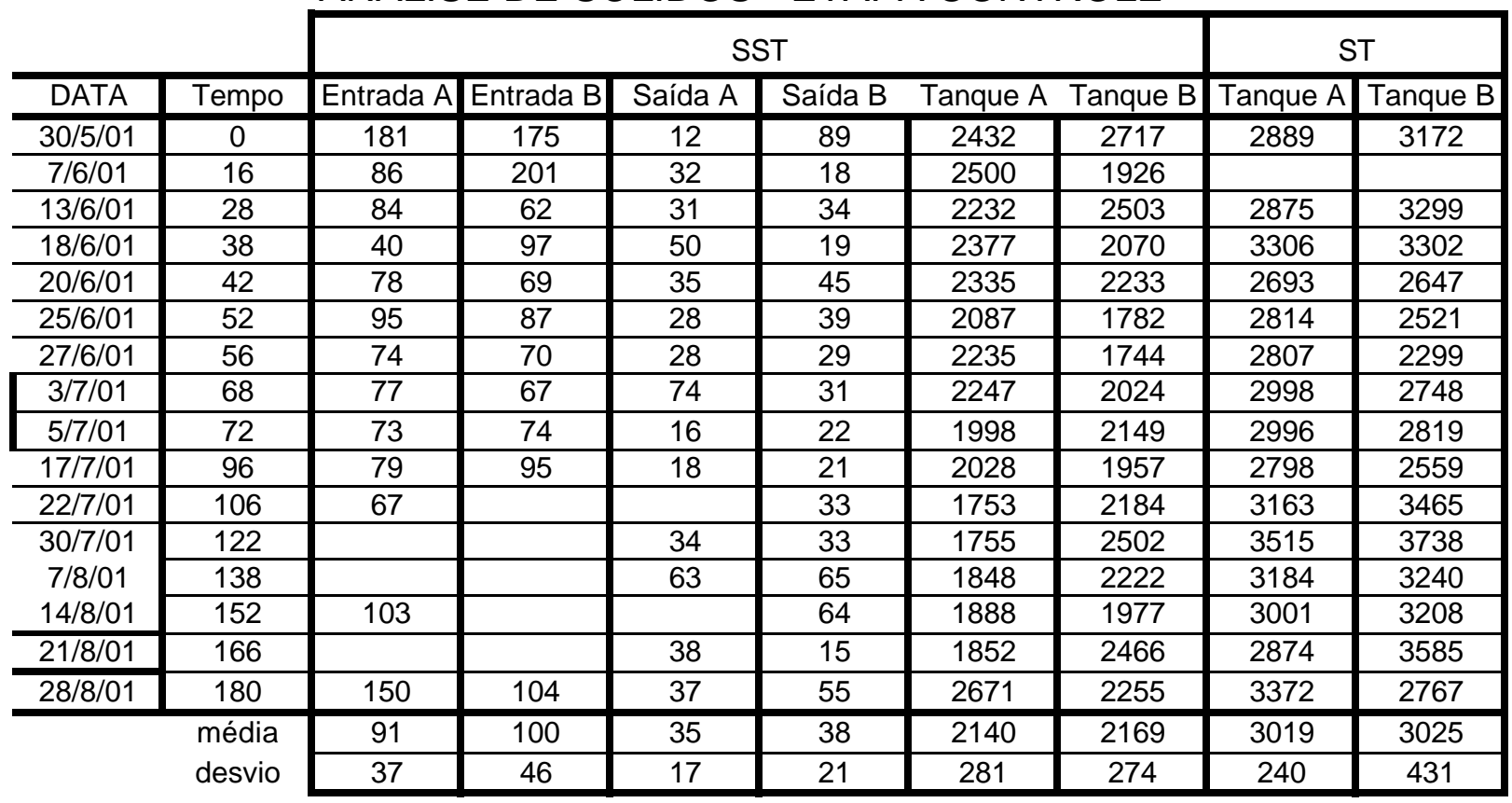


ANÁLISE DE SÓLIDOS - ETAPA CONTROLE - Cont.

\begin{tabular}{|c|c|c|c|c|c|c|c|c|}
\cline { 2 - 9 } \multicolumn{1}{c|}{} & \multicolumn{9}{c|}{ SSF } & \multicolumn{2}{c|}{ SF } \\
\hline Tempo & Entrada A Entrada B & Saída A & Saída B & Tanque A & \multicolumn{2}{c|}{ Tanque B } & Tanque A Tanque B \\
\hline 0 & 41 & 47 & 0 & 30 & 341 & 398 & 725 & 504 \\
\hline 16 & 0 & 0 & 0 & 0 & 653 & 142 & & \\
\hline 28 & 21 & 0 & 4 & 5 & 403 & 440 & 677 & 772 \\
\hline 38 & 0 & 15 & 18 & 1 & 396 & 357 & 704 & 810 \\
\hline 42 & 0 & 2 & 4 & 7 & 371 & 385 & 680 & 691 \\
\hline 52 & 8 & 2 & 10 & 14 & 236 & 94 & 711 & 536 \\
\hline 56 & 5 & 5 & 7 & 0 & 384 & 247 & 753 & 597 \\
\hline 68 & 6 & 0 & 4 & 2 & 390 & 250 & 625 & 593 \\
\hline 72 & 1 & 3 & 3 & 3 & 350 & 300 & 826 & 750 \\
\hline 96 & 3 & 3 & 3 & 4 & 323 & 305 & 675 & 632 \\
\hline 106 & 2 & 0 & 0 & 4 & 236 & 305 & 920 & 857 \\
\hline 122 & & & 15 & 6 & 242 & 431 & 867 & 1005 \\
\hline 138 & & & 37 & 37 & 267 & 394 & 867 & 885 \\
\hline 152 & 34 & & & 35 & 287 & 334 & 797 & 906 \\
\hline 166 & & & 25 & 4 & 283 & 428 & 785 & 904 \\
\hline 180 & 9 & 12 & 5 & 14 & 401 & 445 & 937 & 830 \\
\hline média & 10 & 8 & 9 & 10 & 348 & 328 & 770 & 751 \\
\hline desvio & 14 & 14 & 11 & 12 & 102 & 105 & 96 & 152 \\
\hline
\end{tabular}


ANÁLISE DE SÓLIDOS - ETAPA CONTROLE - Cont.

SSV

SV

\begin{tabular}{|c|c|c|c|c|c|c|c|c|}
\hline Tempo & \multicolumn{2}{|c|}{ Entrada A Entrada B Saída A } & Saída B & Tanque A & Tanque B & Tanque A & Tanque B \\
\hline 0 & 140 & 128 & 12 & 59 & 2092 & 2319 & 2164 & 2668 \\
\hline 16 & 86 & 201 & 32 & 18 & 1847 & 1784 & & \\
\hline 28 & 63 & 62 & 26 & 28 & 1829 & 2063 & 2197 & 2527 \\
\hline 38 & 40 & 82 & 32 & 18 & 1981 & 1713 & 2602 & 2492 \\
\hline 42 & 78 & 67 & 31 & 38 & 1964 & 1848 & 2013 & 1956 \\
\hline 52 & 87 & 85 & 18 & 26 & 1851 & 1688 & 2104 & 1985 \\
\hline 56 & 69 & 65 & 21 & 29 & 1851 & 1496 & 2055 & 1702 \\
\hline 68 & 71 & 67 & 70 & 29 & 1857 & 1774 & 2373 & 2155 \\
\hline 72 & 72 & 71 & 13 & 19 & 1648 & 1849 & 2170 & 2069 \\
\hline 96 & 76 & 91 & 15 & 18 & 1705 & 1653 & 2123 & 1928 \\
\hline 106 & 65 & 55 & 24 & 29 & 1516 & 1879 & 2243 & 2608 \\
\hline 122 & & & 20 & 27 & 1513 & 2071 & 2648 & 2733 \\
\hline 138 & & & 26 & 28 & 1581 & 1827 & 2317 & 2355 \\
\hline 152 & 69 & & & 29 & 1601 & 1643 & 2204 & 2302 \\
\hline 166 & & & 12 & 11 & 1569 & 2037 & 2089 & 2681 \\
\hline 180 & 140 & 92 & 32 & 41 & 2270 & 1810 & 2435 & 1937 \\
\hline média & 81 & 89 & 26 & 28 & 1792 & 1841 & 2249 & 2273 \\
\hline desvio & 29 & 40 & 14 & 11 & 218 & 202 & 191 & 334 \\
\hline
\end{tabular}


ANÁLISE DE SÓLIDOS - ETAPA TESTE

\begin{tabular}{|c|c|c|c|c|c|c|c|c|}
\hline Data & Amostra & Volume & P0 & P1 & P2 & Totais & Fixos & Voláteis \\
\hline \multirow[t]{2}{*}{ sem lise } & Entrada $\mathrm{A}$ & 80 & 23,48854 & 23,50178 & 23,48878 & 165 & 3 & 163 \\
\hline & Entrada B & 75 & 23,70736 & 23,72279 & 23,70755 & 206 & 3 & 203 \\
\hline \multirow{9}{*}{$\begin{array}{l}\text { com lise } \\
1 / 12 / 01\end{array}$} & Entrada A & 44 & 23,72531 & 23,73917 & 23,72554 & 315 & 5 & 310 \\
\hline & EntradaB & 35 & 28,63545 & 28,64735 & 28,63617 & 340 & 21 & 319 \\
\hline & Saída A & 75 & 26,21092 & 26,21588 & 26,21098 & 66 & 1 & 65 \\
\hline & Saída B & 80 & 24,71870 & 24,72010 & 24,71882 & 18 & 2 & 16 \\
\hline & Tanque $\mathrm{A}$ & 15 & 23,14967 & 23,18757 & 23,15236 & 2527 & 179 & 2347 \\
\hline & Tanque $\mathrm{B}$ & 15 & 26,75950 & 26,79185 & 26,76118 & 2157 & 112 & 2045 \\
\hline & Tanque $\mathrm{A}$ & 90 & 92,02410 & 92,30400 & 92,10230 & 3110 & 869 & 2241 \\
\hline & Tanque $\mathrm{B}$ & 90 & 82,75490 & 82,99080 & 82,82970 & 2621 & 831 & 1790 \\
\hline & Amostra & Volume & P0 & $\mathrm{P} 1$ & P2 & Totais & Fixos & Voláteis \\
\hline \multirow[t]{2}{*}{ sem lise } & Entrada A & 90 & 23,88394 & 23,90040 & 23,88411 & 183 & 2 & 181 \\
\hline & Entrada B & 90 & 22,96965 & 22,98473 & 22,96986 & 168 & 2 & 165 \\
\hline \multirow[t]{2}{*}{ com lise } & Entrada A & 45 & 23,30381 & 23,31698 & 23,30398 & 293 & 4 & 289 \\
\hline & EntradaB & 45 & 22,27645 & 22,28764 & 22,27700 & 249 & 12 & 236 \\
\hline \multirow[t]{7}{*}{$4 / 12 / 01$} & Saída A & 90 & 25,13811 & 25,14464 & 25,13770 & 73 & 0 & 73 \\
\hline & Saída B & 90 & 19,22459 & 19,22680 & 19,22483 & 25 & 3 & 22 \\
\hline & Tanque $\mathrm{A}$ & 19 & 25,99306 & 26,04380 & 25,99882 & 2671 & 303 & 2367 \\
\hline & Tanque B & 19 & 21,31847 & 21,35873 & 21,32140 & 2119 & 154 & 1965 \\
\hline & Tanque $\mathrm{A}$ & 80 & 80,68160 & 80,96260 & 80,75170 & 3512 & 876 & 2636 \\
\hline & Tanque $\mathrm{B}$ & 80 & 80,29120 & 80,52290 & 80,35860 & 2896 & 842 & 2054 \\
\hline & Amostra & Volume & P0 & $\mathrm{P} 1$ & P2 & Totais & Fixos & Voláteis \\
\hline \multirow[t]{2}{*}{ sem lise } & Entrada A & 90 & 26,56203 & 26,57760 & 26,56256 & 173 & 6 & 167 \\
\hline & Entrada B & 90 & 24,41748 & 24,43147 & 24,41938 & 155 & 21 & 134 \\
\hline \multirow[t]{2}{*}{ com lise } & Entrada A & 40 & 23,50171 & 23,51696 & 23,50412 & 381 & 60 & 321 \\
\hline & EntradaB & 35 & 21,24213 & 21,25356 & 21,24265 & 327 & 15 & 312 \\
\hline \multirow[t]{7}{*}{$9 / 12 / 01$} & Saída A & 90 & 24,67035 & 24,67435 & 24,67135 & 44 & 11 & 33 \\
\hline & Saída B & 90 & 21,65640 & 21,65845 & & 23 & 0 & 23 \\
\hline & Tanque $\mathrm{A}$ & 19 & 23,14931 & 23,20035 & 23,15625 & 2686 & 365 & 2321 \\
\hline & Tanque B & 19 & 24,02376 & 24,06575 & 24,02885 & 2210 & 268 & 1942 \\
\hline & Tanque $\mathrm{A}$ & 90 & 90,66410 & 90,97900 & 90,74490 & 3499 & 898 & 2601 \\
\hline & Tanque $\mathrm{B}$ & 90 & 142,24880 & 142,49830 & 142,32180 & 2772 & 811 & 1961 \\
\hline & Amostra & Volume & P0 & P1 & P2 & Totais & Fixos & Voláteis \\
\hline \multirow[t]{2}{*}{ sem lise } & Entrada A & 80 & 20,58342 & 20,59882 & 20,58359 & 192 & 2 & 190 \\
\hline & Entrada B & 90 & 25,63655 & 25,65138 & 25,63702 & 165 & 5 & 160 \\
\hline \multirow[t]{2}{*}{ com lise } & Entrada A & 30 & 25,99167 & 26,00608 & 25,99245 & 480 & 26 & 454 \\
\hline & EntradaB & 30 & 22,52112 & 22,53168 & 22,52163 & 352 & 17 & 335 \\
\hline \multirow[t]{6}{*}{$12 / 12 / 01$} & Saída A & 90 & 23,30362 & 23,30744 & 23,30410 & 42 & 5 & 37 \\
\hline & Saída B & 90 & 26,64604 & 26,64835 & 26,64624 & 26 & 2 & 23 \\
\hline & Tanque $\mathrm{A}$ & 19 & 26,30703 & 26,35637 & 26,31381 & 2597 & 357 & 2240 \\
\hline & Tanque B & 19 & 25,13875 & 25,17463 & 25,14350 & 1888 & 250 & 1638 \\
\hline & Tanque $\mathrm{A}$ & 80 & 79,01490 & 79,28990 & 79,08419 & 3438 & 866 & 2571 \\
\hline & Tanque $\mathrm{B}$ & 80 & 83,00240 & 83,21390 & 83,06650 & 2644 & 801 & 1842 \\
\hline
\end{tabular}


ANÁLISE DE SÓLIDOS - ETAPA TESTE - Cont.

\begin{tabular}{|c|c|c|c|c|c|c|c|c|}
\hline & & & & & \multirow{2}{*}{\multicolumn{2}{|c|}{ Totais }} & \multirow[b]{2}{*}{ Fixos } & \multirow[b]{2}{*}{ Voláteis } \\
\hline Data & \multicolumn{2}{|c|}{ Amostra Volume } & \multicolumn{2}{|c|}{$\begin{array}{ll}\mathrm{P} 0 & \mathrm{P} 1 \\
\end{array}$} & & & & \\
\hline \multirow[t]{2}{*}{ sem lise } & Entrada A & \begin{tabular}{|l|}
90 \\
\end{tabular} & 24,42051 & 24,43347 & 24,42120 & 144 & 8 & 136 \\
\hline & Entrada B & 90 & 24,72419 & 24,74290 & 24,72458 & 208 & 4 & 204 \\
\hline \multirow[t]{2}{*}{ com lise } & Entrada A & 30 & 24,30164 & 24,31385 & 24,30310 & 407 & 49 & 358 \\
\hline & EntradaB & 30 & 24,66772 & 24,67771 & 24,66842 & 333 & 23 & 310 \\
\hline \multirow[t]{7}{*}{$15 / 12 / 01$} & Saída A & 90 & 32,61260 & 32,61420 & 32,61284 & 18 & 3 & 15 \\
\hline & Saída B & 90 & 23,64016 & 23,64500 & 23,64111 & 54 & 11 & 43 \\
\hline & Tanque $\mathrm{A}$ & 19 & 25,20125 & 25,25745 & 25,20780 & 2958 & 345 & 2613 \\
\hline & Tanque B & 19 & 21,24317 & 21,28357 & 21,24690 & 2126 & 196 & 1930 \\
\hline & Tanque $\mathrm{A}$ & 70 & 89,06340 & 89,31920 & 89,11650 & 3654 & 759 & 2896 \\
\hline & Tanque $\mathrm{B}$ & 70 & 87,26800 & 87,49800 & 87,32870 & 3286 & 867 & 2419 \\
\hline & Amostra & Volume & P0 & $\mathrm{P} 1$ & $\mathrm{P} 2$ & Totais & Fixos & Voláteis \\
\hline \multirow[t]{2}{*}{ sem lise } & Entrada A & 90 & 24,02470 & 24,04020 & 24,02534 & 172 & 7 & 165 \\
\hline & Entrada B & 90 & 19,92384 & 19,94060 & 19,92408 & 186 & 3 & 184 \\
\hline \multirow[t]{2}{*}{ com lise } & Entrada A & 30 & 21,74636 & 21,75437 & 21,74767 & 267 & 44 & 223 \\
\hline & EntradaB & 30 & 22,39975 & 22,40909 & 22,40057 & 311 & 27 & 284 \\
\hline \multirow[t]{7}{*}{$17 / 12 / 01$} & Saída A & 90 & 25,93096 & 25,93462 & 25,93219 & 41 & 14 & 27 \\
\hline & Saída B & 90 & 21,32060 & 21,32617 & 21,32174 & 62 & 13 & 49 \\
\hline & Tanque $\mathrm{A}$ & 19 & 22,27924 & 22,33993 & 22,28644 & 3194 & 379 & 2815 \\
\hline & Tanque $\mathrm{B}$ & 19 & 23,14902 & 23,19488 & 23,15202 & 2414 & 158 & 2256 \\
\hline & Tanque $\mathrm{A}$ & 90 & 80,69390 & 81,00230 & 80,77340 & 3427 & 883 & 2543 \\
\hline & Tanque $\mathrm{B}$ & 90 & 80,29840 & 80,60280 & 80,37160 & 3382 & 813 & 2569 \\
\hline & Amostra & Volume & P0 & P1 & P2 & Totais & Fixos & Voláteis \\
\hline \multirow[t]{2}{*}{ sem lise } & Entrada A & 90 & 23,63839 & 23,65393 & 23,64087 & 173 & 28 & 145 \\
\hline & Entrada B & 90 & 19,85897 & 19,86840 & 19,85949 & 105 & 6 & 99 \\
\hline \multirow[t]{2}{*}{ com lise } & Entrada A & 50 & 23,47965 & 23,49550 & 23,48312 & 317 & 69 & 248 \\
\hline & EntradaB & 50 & 24,30061 & 24,31546 & 24,30413 & 297 & 70 & 227 \\
\hline \multirow[t]{7}{*}{$19 / 12 / 01$} & Saída A & 90 & 25,19882 & 25,20300 & 25,20102 & 46 & 24 & 22 \\
\hline & Saída B & 90 & 25,67385 & 25,67987 & 25,67700 & 67 & 35 & 32 \\
\hline & Tanque $\mathrm{A}$ & 19 & 22,05420 & 22,11300 & 22,06289 & 3095 & 457 & 2637 \\
\hline & Tanque B & 19 & 24,66853 & 24,70523 & 24,67352 & 1932 & 263 & 1669 \\
\hline & Tanque $\mathrm{A}$ & 80 & 83,87430 & 84,21710 & 83,96030 & 4285 & 1075 & 3210 \\
\hline & Tanque $\mathrm{B}$ & 80 & 90,65850 & 90,91270 & 90,73540 & 3177 & 961 & 2216 \\
\hline & Amostra & Volume & P0 & $\mathrm{P} 1$ & $\mathrm{P} 2$ & Totais & Fixos & Voláteis \\
\hline \multirow[t]{2}{*}{ sem lise } & Entrada A & 90 & 23,66435 & 23,67828 & 23,66469 & 155 & 4 & 151 \\
\hline & Entrada B & 90 & 18,78805 & 18,80335 & 18,78804 & 170 & 0 & 170 \\
\hline \multirow[t]{2}{*}{ com lise } & Entrada A & 50 & 26,56238 & 26,57641 & 26,56472 & 281 & 47 & 234 \\
\hline & EntradaB & 50 & 23,88591 & 23,89920 & 23,88784 & 266 & 39 & 227 \\
\hline \multirow[t]{6}{*}{$28 / 12 / 01$} & Saída A & 90 & 22,81871 & 22,82193 & 22,81915 & 36 & 5 & 31 \\
\hline & Saída B & 90 & 29,09888 & 29,09931 & 29,09922 & 5 & 4 & 1 \\
\hline & Tanque $\mathrm{A}$ & 19 & 26,09651 & 26,14873 & 26,09923 & 2748 & 143 & 2605 \\
\hline & Tanque B & 19 & 26,21424 & 26,25375 & 26,21628 & 2079 & 107 & 1972 \\
\hline & Tanque $\mathrm{A}$ & 90 & 79,02200 & 79,35995 & 79,08830 & 3755 & 737 & 3018 \\
\hline & Tanque B & 90 & 96,88170 & 97,14990 & 96,95200 & 2980 & 781 & 2199 \\
\hline
\end{tabular}


ANÁLISE DE SÓLIDOS - ETAPA TESTE - Cont.

\begin{tabular}{|c|c|c|c|c|c|c|c|c|}
\hline \multirow{3}{*}{ sem lise } & Amostra & Volume & P0 & $\mathrm{P} 1$ & P2 & Totais & Fixos & Voláteis \\
\hline & Entrada A & 90 & 24,30330 & 24,31599 & 24,30351 & 141 & 2 & 139 \\
\hline & Entrada B & 90 & 25,67460 & 25,68836 & 25,67528 & 153 & 8 & 145 \\
\hline \multirow[t]{2}{*}{ com lise } & Entrada A & 50 & 19,85909 & 19,87441 & 19,85998 & 306 & 18 & 289 \\
\hline & EntradaB & 50 & 19,26646 & 19,27922 & 19,26727 & 255 & 16 & 239 \\
\hline \multirow[t]{7}{*}{$30 / 12 / 01$} & Saída A & 90 & 23,64274 & 23,64780 & 23,64345 & 56 & 8 & 48 \\
\hline & Saída B & 90 & 24,66724 & 24,67217 & 24,66799 & 55 & 8 & 46 \\
\hline & Tanque $\mathrm{A}$ & 19 & 22,05853 & 22,10897 & 22,06318 & 2655 & 245 & 2410 \\
\hline & Tanque B & 19 & 23,48144 & 23,52146 & 23,48590 & 2106 & 235 & 1872 \\
\hline & Tanque $\mathrm{A}$ & 90 & 90,66170 & 90,99040 & 90,74150 & 3652 & 887 & 2766 \\
\hline & Tanque $\mathrm{B}$ & 90 & 83,86720 & 84,15230 & 83,95150 & 3168 & 937 & 2231 \\
\hline & Amostra & Volume & P0 & $\mathrm{P} 1$ & $\mathrm{P} 2$ & Totais & Fixos & Voláteis \\
\hline \multirow[t]{2}{*}{ sem lise } & Entrada $\mathrm{A}$ & 90 & 22,39930 & 22,41960 & 22,40130 & 226 & 22 & 203 \\
\hline & Entrada B & 90 & 30,37320 & 30,38629 & 30,37394 & 145 & 8 & 137 \\
\hline \multirow[t]{2}{*}{ com lise } & Entrada A & 50 & 24,02677 & 24,04491 & 24,02834 & 363 & 31 & 331 \\
\hline & EntradaB & 50 & 21,77319 & 21,78800 & 21,77493 & 296 & 35 & 261 \\
\hline \multirow[t]{7}{*}{$3 / 1 / 02$} & Saída A & 90 & 25,52250 & 25,52875 & 25,52336 & 69 & 10 & 60 \\
\hline & Saída B & 90 & 23,29366 & 23,29963 & 23,29550 & 66 & 20 & 46 \\
\hline & Tanque $\mathrm{A}$ & 19 & 21,97695 & 22,03010 & 21,98294 & 2797 & 315 & 2482 \\
\hline & Tanque B & 19 & 25,20162 & 25,24744 & 25,20717 & 2412 & 292 & 2119 \\
\hline & Tanque $\mathrm{A}$ & 70 & 96,88710 & 97,15420 & 96,95040 & 3816 & 904 & 2911 \\
\hline & Tanque $\mathrm{B}$ & 70 & 79,02600 & 79,25460 & 79,08800 & 3266 & 886 & 2380 \\
\hline & Amostra & Volume & P0 & P1 & P2 & Totais & Fixos & Voláteis \\
\hline \multirow[t]{2}{*}{ sem lise } & Entrada A & 90 & 23,48419 & 23,49990 & 23,48434 & 175 & 2 & 173 \\
\hline & Entrada B & 90 & 26,56409 & 26,57797 & 26,56493 & 154 & 9 & 145 \\
\hline \multirow[t]{2}{*}{ com lise } & Entrada $\mathrm{A}$ & 50 & 25,67751 & 25,69099 & 25,67765 & 270 & 3 & 267 \\
\hline & EntradaB & 50 & 26,21178 & 26,22463 & 26,21212 & 257 & 7 & 250 \\
\hline \multirow[t]{7}{*}{$7 / 1 / 02$} & Saída A & 90 & 22,05850 & 22,06183 & 22,05992 & 37 & 16 & 21 \\
\hline & Saída B & 90 & 23,66284 & 23,66928 & 23,66400 & 72 & 13 & 59 \\
\hline & Tanque $\mathrm{A}$ & 19 & 19,26712 & 19,32251 & 19,27154 & 2915 & 233 & 2683 \\
\hline & Tanque $\mathrm{B}$ & 19 & 23,64451 & 23,68401 & 23,64893 & 2079 & 233 & 1846 \\
\hline & Tanque $\mathrm{A}$ & 80 & 90,67130 & 90,97670 & 90,73580 & 3817 & 806 & 3011 \\
\hline & Tanque B & 80 & 83,87530 & 84,13720 & 83,94110 & 3274 & 823 & 2451 \\
\hline & Amostra & Volume & P0 & P1 & P2 & Totais & Fixos & Voláteis \\
\hline \multirow[t]{2}{*}{ sem lise } & Entrada A & 90 & 24,02449 & 24,03717 & 24,02563 & 141 & 13 & 128 \\
\hline & Entrada B & 90 & 30,37286 & 30,38807 & 30,37340 & 169 & 6 & 163 \\
\hline \multirow[t]{2}{*}{ com lise } & Entrada A & 45 & 22,39734 & 22,41215 & 22,40031 & 329 & 66 & 263 \\
\hline & EntradaB & 30 & 25,52111 & 25,52960 & 25,52182 & 283 & 24 & 259 \\
\hline \multirow[t]{6}{*}{$11 / 1 / 02$} & Saída A & 90 & 23,29232 & 23,29790 & 23,29458 & 62 & 25 & 37 \\
\hline & Saída B & 90 & 25,20133 & 25,20595 & 25,20325 & 51 & 21 & 30 \\
\hline & Tanque $\mathrm{A}$ & 19 & 21,77373 & 21,83645 & 21,78155 & 3301 & 412 & 2889 \\
\hline & Tanque B & 19 & 21,97633 & 22,02276 & 21,98343 & 2444 & 374 & 2070 \\
\hline & Tanque $\mathrm{A}$ & 90 & 96,88340 & 97,25230 & 96,99070 & 4099 & 1192 & 2907 \\
\hline & Tanque B & 90 & 79,02470 & 79,33300 & 79,13440 & 3426 & 1219 & 2207 \\
\hline
\end{tabular}


ANÁLISE DE SÓLIDOS - ETAPA TESTE - Cont.

Data

\begin{tabular}{|c|c|c|c|c|c|c|c|c|}
\hline \multirow{3}{*}{ sem lise } & Amostra & Volume & $\mathrm{P} 0$ & P1 & P2 & Totais & Fixos & Voláteis \\
\hline & Entrada A & 90 & 23,88689 & 23,90438 & 23,88866 & 194 & 20 & 175 \\
\hline & Entrada B & 90 & 25,67572 & 25,68860 & 25,67647 & 143 & 8 & 135 \\
\hline \multirow[t]{2}{*}{ com lise } & Entrada A & 30 & 24,72756 & 24,73814 & 24,72884 & 353 & 43 & 310 \\
\hline & EntradaB & 30 & 20,75766 & 20,76644 & 20,75910 & 293 & 48 & 245 \\
\hline \multirow[t]{7}{*}{$14 / 1 / 02$} & Saída A & 90 & 23,66081 & 23,66474 & 23,66257 & 44 & 20 & 24 \\
\hline & Saída B & 90 & 23,48201 & 23,48879 & 23,48286 & 75 & 9 & 66 \\
\hline & Tanque $\mathrm{A}$ & 19 & 26,09290 & 26,15490 & 26,09858 & 3263 & 299 & 2964 \\
\hline & Tanque $\mathrm{B}$ & 19 & 23,14924 & 23,19166 & 23,15480 & 2233 & 293 & 1940 \\
\hline & Tanque A & 90 & 80,30510 & 80,71510 & 80,38240 & 4556 & 859 & 3697 \\
\hline & Tanque B & 70 & 83,87260 & 84,10580 & 83,92530 & 3331 & 753 & 2579 \\
\hline & Amostra & Volume & $\mathrm{P} 0$ & $\mathrm{P} 1$ & P2 & Totais & Fixos & Voláteis \\
\hline \multirow[t]{2}{*}{ sem lise } & Entrada A & 90 & 26,40498 & 26,41272 & 26,40657 & 86 & 18 & 68 \\
\hline & Entrada B & 90 & 21,77594 & 21,78713 & 21,77726 & 124 & 15 & 110 \\
\hline \multirow[t]{2}{*}{ com lise } & Entrada A & 30 & 21,32363 & 21,33429 & 21,32560 & 355 & 66 & 290 \\
\hline & EntradaB & 30 & 24,02773 & 24,03489 & 24,02895 & 239 & 41 & 198 \\
\hline \multirow[t]{6}{*}{ 21/1/02 } & Saída A & 90 & 23,29674 & 23,29967 & 23,29747 & 33 & 8 & 24 \\
\hline & Saída B & 90 & 21,98099 & 21,98608 & 21,98254 & 57 & 17 & 39 \\
\hline & Tanque A & 19 & 25,20450 & 25,27047 & 25,20905 & 3472 & 239 & 3233 \\
\hline & Tanque B & 19 & 28,63681 & 28,68314 & 28,64286 & 2438 & 318 & 2120 \\
\hline & Tanque $\mathrm{A}$ & 70 & 96,89040 & 97,20060 & 96,93980 & 4431 & 706 & 3726 \\
\hline & Tanque B & 80 & 79,03036 & 79,28900 & 79,09210 & 3233 & 772 & 2461 \\
\hline
\end{tabular}

sem lise

com lise

$24 / 1 / 02$

Amostra Volume $\mathrm{P} 0$

\begin{tabular}{|c|c|c|c|c|c|c|c|}
\hline Entrada A & 90 & 21,24311 & 21,25609 & 21,24386 & 144 & 8 & 136 \\
\hline Entrada B & 90 & 25,14350 & 25,15927 & 25,14367 & 175 & 2 & 173 \\
\hline Entrada A & 30 & 25,93541 & 25,94622 & 25,93606 & 360 & 22 & 339 \\
\hline EntradaB & 30 & 23,15130 & 23,16026 & 23,15230 & 299 & 33 & 265 \\
\hline Saída A & 90 & 24,66972 & 24,67213 & 24,67025 & 27 & 6 & 21 \\
\hline Saída B & 90 & 22,82252 & 22,82606 & 22,82359 & 39 & 12 & 27 \\
\hline Tanque A & 19 & 26,56360 & 26,63293 & 26,57083 & 3649 & 381 & 3268 \\
\hline Tanque B & 19 & 20,58681 & 20,63508 & 20,59236 & 2541 & 292 & 2248 \\
\hline Tanque A & 90 & 90,66640 & 91,07440 & 90,75370 & 4533 & 970 & 3563 \\
\hline
\end{tabular}

sem lise

com lise

28/1/02

\begin{tabular}{c|c|c|c|c|c|c|c|}
\hline Amostra & Volume & P0 & P1 & P2 & \multicolumn{1}{c}{ Totais } & \multicolumn{1}{c|}{ Fixos } & \multicolumn{1}{c|}{ Voláteis } \\
\hline Entrada A & 90 & 26,06783 & 26,07778 & 26,06844 & 111 & 7 & 104 \\
\hline Entrada B & 90 & 24,72079 & 24,73569 & 24,72198 & 166 & 13 & 152 \\
\hline Entrada A & 40 & 26,21197 & 26,22406 & 26,21264 & 302 & 17 & 286 \\
\hline EntradaB & 40 & 25,63838 & 25,65196 & 25,63998 & 339 & 40 & 299 \\
\hline Saída A & 90 & 24,27082 & 24,27296 & 24,27101 & 24 & 2 & 22 \\
\hline Saída B & 90 & 26,75791 & 26,76414 & 26,75809 & 69 & 2 & 67 \\
\hline Tanque A & 19 & 21,74993 & 21,81891 & 21,75589 & 3631 & 314 & 3317 \\
\hline Tanque B & 19 & 23,70914 & 23,75687 & 23,71435 & 2512 & 274 & 2238 \\
\hline Tanque A & 75 & 79,03240 & 79,36890 & 79,09390 & 4487 & 820 & 3667 \\
\hline Tanque B & 80 & 96,89350 & 97,20450 & 96,96860 & 3887 & 939 & 2949 \\
\hline
\end{tabular}




\begin{tabular}{|c|c|c|c|c|c|c|c|c|}
\hline \multirow{2}{*}{ Data } & \multicolumn{8}{|c|}{ ANÁLISE DE SÓLIDOS - ETAPA TESTE - Cont. } \\
\hline & Amostra & Volume & P0 & $\mathrm{P} 1$ & P2 & Totais & Fixos & Voláteis \\
\hline \multirow[t]{2}{*}{ sem lise } & Entrada A & \begin{tabular}{|l|}
90 \\
\end{tabular} & 24,02854 & 24,03538 & 24,02979 & 76 & 14 & 62 \\
\hline & Entrada B & 90 & 21,24557 & 21,25398 & 21,24880 & 93 & 36 & 58 \\
\hline \multirow[t]{2}{*}{ com lise } & Entrada A & 30 & 20,58678 & 20,59744 & 20,58837 & 355 & 53 & 302 \\
\hline & EntradaB & 30 & 25,14246 & 25,15159 & 25,14351 & 304 & 35 & 269 \\
\hline \multirow[t]{7}{*}{$4 / 2 / 02$} & Saída A & 90 & 26,56468 & 26,56674 & 26,56592 & 23 & 14 & 9 \\
\hline & Saída B & 90 & 23,15287 & 23,15588 & 23,15330 & 33 & 5 & 29 \\
\hline & Tanque $\mathrm{A}$ & 19 & 25,93410 & 26,00585 & 25,93956 & 3776 & 287 & 3489 \\
\hline & Tanque B & 19 & 24,66931 & 24,71901 & 24,67658 & 2616 & 383 & 2233 \\
\hline & Tanque $\mathrm{A}$ & 90 & 90,67310 & 91,08030 & 90,74600 & 4524 & 810 & 3714 \\
\hline & Tanque $\mathrm{B}$ & 90 & 89,00640 & 89,36050 & 89,08180 & 3934 & 838 & 3097 \\
\hline & Amostra & Volume & $\mathrm{P} 0$ & $\mathrm{P} 1$ & P2 & Totais & Fixos & Voláteis \\
\hline \multirow[t]{2}{*}{ sem lise } & Entrada A & \begin{tabular}{|l|}
90 \\
\end{tabular} & 26,75376 & 26,76508 & 26,75482 & 126 & 12 & 114 \\
\hline & Entrada B & 90 & 24,72122 & 24,73118 & 24,72245 & 111 & 14 & 97 \\
\hline \multirow[t]{2}{*}{ com lise } & Entrada A & 30 & 23,64067 & 23,65066 & 23,64183 & 333 & 39 & 294 \\
\hline & EntradaB & 30 & 23,70594 & 23,71457 & 23,70698 & 288 & 35 & 253 \\
\hline \multirow[t]{7}{*}{$6 / 2 / 02$} & Saída A & 90 & 23,72652 & 23,72994 & 23,72781 & 38 & 14 & 24 \\
\hline & Saída B & 90 & 23,48786 & 23,48953 & 23,48879 & 19 & 10 & 8 \\
\hline & Tanque $\mathrm{A}$ & 19 & 26,09108 & 26,16431 & 26,09754 & 3854 & 340 & 3514 \\
\hline & Tanque B & 19 & 19,26768 & 19,31661 & 19,27505 & 2575 & 388 & 2187 \\
\hline & Tanque $\mathrm{A}$ & 90 & 80,29980 & 80,72010 & 80,38930 & 4670 & 994 & 3676 \\
\hline & Tanque B & 90 & 83,86160 & 84,19170 & 83,94620 & 3668 & 940 & 2728 \\
\hline & Amostra & Volume & P0 & P1 & P2 & Totais & Fixos & Voláteis \\
\hline \multirow[t]{2}{*}{ sem lise } & Entrada A & 90 & 27,31385 & 27,32133 & 27,31443 & 83 & 6 & 77 \\
\hline & Entrada B & 90 & 25,14282 & 25,14875 & 25,14304 & 66 & 2 & 63 \\
\hline \multirow[t]{2}{*}{ com lise } & Entrada A & 30 & 21,55522 & 21,56389 & 21,55588 & 289 & 22 & 267 \\
\hline & EntradaB & 30 & 23,88639 & 23,89205 & 23,88699 & 189 & 20 & 169 \\
\hline \multirow[t]{7}{*}{$15 / 2 / 02$} & Saída A & 90 & 23,64312 & 23,64631 & 23,64345 & 35 & 4 & 32 \\
\hline & Saída B & 90 & 22,45454 & 22,45777 & 22,45526 & 36 & 8 & 28 \\
\hline & Tanque $\mathrm{A}$ & 19 & 22,81997 & 22,89689 & 22,83026 & 4048 & 542 & 3507 \\
\hline & Tanque B & 19 & 25,99437 & 26,05432 & 26,00375 & 3155 & 494 & 2662 \\
\hline & Tanque $\mathrm{A}$ & 90 & 80,31120 & 80,73280 & 80,41170 & 4684 & 1117 & 3568 \\
\hline & Tanque B & 90 & 80,69960 & 81,02530 & 80,79940 & 3619 & 1109 & 2510 \\
\hline & Amostra & Volume & P0 & P1 & P2 & Totais & Fixos & Voláteis \\
\hline \multirow[t]{2}{*}{ sem lise } & Entrada A & \begin{tabular}{|l|}
90 \\
\end{tabular} & 22,54863 & 22,55697 & 22,54873 & 93 & 1 & 92 \\
\hline & Entrada B & 90 & 27,28312 & 27,28991 & 27,28374 & 75 & 7 & 69 \\
\hline \multirow[t]{2}{*}{ com lise } & Entrada A & 30 & 26,30969 & 26,31971 & 26,31086 & 334 & 39 & 295 \\
\hline & EntradaB & 30 & 21,98366 & 21,99327 & 21,98430 & 320 & 21 & 299 \\
\hline \multirow[t]{7}{*}{$18 / 2 / 02$} & Saída A & 90 & 26,06840 & 26,07079 & 26,06847 & 27 & 1 & 26 \\
\hline & Saída B & 90 & 26,04287 & 26,04696 & 26,04339 & 45 & 6 & 40 \\
\hline & Tanque $\mathrm{A}$ & 19 & 24,71600 & 24,78880 & 24,72784 & 3832 & 623 & 3208 \\
\hline & Tanque B & 19 & 20,63856 & 20,69874 & 20,65150 & 3167 & 681 & 2486 \\
\hline & Tanque $\mathrm{A}$ & 90 & 96,89170 & 97,31270 & 97,00018 & 4678 & 1205 & 3472 \\
\hline & Tanque $B$ & 90 & 79,03540 & 79,36190 & 79,13280 & 3628 & 1082 & 2546 \\
\hline & Amostra & Volume & P0 & P1 & P2 & Totais & Fixos & Voláteis \\
\hline \multirow[t]{2}{*}{ sem lise } & Entrada A & 90 & 21,55935 & 21,57199 & 22,54873 & 140 & 10993 & -10853 \\
\hline & Entrada B & 90 & 25,99601 & 26,00908 & 27,28374 & 145 & 14308 & -14163 \\
\hline \multirow[t]{2}{*}{ com lise } & Entrada A & 30 & 25,14577 & 25,15713 & 26,31086 & 379 & 38836 & -38458 \\
\hline & EntradaB & 30 & 27,31814 & 27,32678 & 21,98430 & 288 & 0 & 288 \\
\hline \multirow[t]{6}{*}{ 20/2/02 } & Saída A & 90 & 22,82347 & 22,82541 & 26,06847 & 22 & 36056 & -36034 \\
\hline & Saída B & 90 & 23,88927 & 23,89333 & 26,04339 & 45 & 23935 & -23890 \\
\hline & Tanque $\mathrm{A}$ & 19 & 22,45722 & 22,53712 & 24,72784 & 4205 & 119506 & -115301 \\
\hline & Tanque $\mathrm{B}$ & 19 & 23,64576 & 23,71333 & 20,65150 & 3556 & 0 & 3556 \\
\hline & Tanque $\mathrm{A}$ & 90 & 80,31360 & 80,82040 & 97,00018 & 5631 & 185406 & -179775 \\
\hline & Tanque B & 90 & 80,70000 & 81,08740 & 79,13280 & 4304 & 0 & 4304 \\
\hline
\end{tabular}


ANÁLISE DE SÓLIDOS - ETAPA TESTE

\begin{tabular}{|c|c|c|c|c|c|c|c|c|c|c|c|}
\hline & \multicolumn{9}{|c|}{ SST } & \multicolumn{2}{|c|}{ ST } \\
\hline DATA & Tempo & Entrada A & Entrada B & Ent. A (lise) & Ent. B (lise) & Saída A & Saída B & Tanque $\mathrm{A}$ & Tanque B & Tanque $\mathrm{A}$ & Tanque B \\
\hline $01 / 12 / 01$ & 8 & 165 & 206 & 315 & 340 & 66 & 18 & 2527 & 2157 & 3110 & 2621 \\
\hline $04 / 12 / 01$ & 14 & 183 & 168 & 293 & 249 & 73 & 25 & 2671 & 2119 & 3512 & 2896 \\
\hline $09 / 12 / 01$ & 24 & 173 & 155 & 381 & 327 & 0 & 23 & 2686 & 2210 & 3499 & 2772 \\
\hline $12 / 12 / 01$ & 30 & 192 & 165 & 480 & 352 & 42 & 26 & 2597 & 1888 & 3438 & 2644 \\
\hline $15 / 12 / 01$ & 36 & 144 & 208 & 407 & 333 & 18 & 54 & 2958 & 2126 & 3654 & 3286 \\
\hline $17 / 12 / 01$ & 40 & 172 & 186 & 267 & 311 & 41 & 62 & 3194 & 2414 & 4649 & 4493 \\
\hline $19 / 12 / 01$ & 44 & 173 & 105 & 317 & 297 & 46 & 67 & 3095 & 1932 & 4285 & 3177 \\
\hline $28 / 12 / 01$ & 62 & 155 & 170 & 281 & 266 & 36 & 5 & 2748 & 2079 & 3755 & 2980 \\
\hline $30 / 12 / 01$ & 66 & 141 & 153 & 306 & 255 & 56 & 55 & 2655 & 2106 & 3652 & 3168 \\
\hline $03 / 01 / 02$ & 74 & 226 & 145 & 363 & 296 & 69 & 66 & 2797 & 2412 & 3816 & 3266 \\
\hline $07 / 01 / 02$ & 82 & 175 & 154 & 270 & 257 & 37 & 72 & 2915 & 2079 & 3817 & 3274 \\
\hline $11 / 01 / 02$ & 90 & 141 & 169 & 329 & 283 & 62 & 51 & 3301 & 2444 & 4099 & 3426 \\
\hline $14 / 01 / 02$ & 96 & 194 & 143 & 353 & 293 & 44 & 75 & 3263 & 2233 & 4556 & 3331 \\
\hline $21 / 01 / 02$ & 110 & 86 & 124 & 355 & 239 & 33 & 57 & 3472 & 2438 & 4431 & 3233 \\
\hline $24 / 01 / 02$ & 116 & 144 & 175 & 360 & 299 & 27 & 39 & 3649 & 2541 & 4533 & 3417 \\
\hline $28 / 01 / 02$ & 124 & 111 & 166 & 302 & 339 & 24 & 69 & 3631 & 2512 & 4487 & 3887 \\
\hline $04 / 02 / 02$ & 138 & 76 & 93 & 355 & 304 & 23 & 33 & 3776 & 2616 & 4524 & 3934 \\
\hline $06 / 02 / 02$ & 142 & 126 & 111 & 333 & 288 & 38 & 19 & 3854 & 2575 & 4670 & 3668 \\
\hline $15 / 02 / 02$ & 160 & 83 & 66 & 289 & 189 & 35 & 36 & 4048 & 3155 & 4684 & 3619 \\
\hline $18 / 02 / 02$ & 166 & 93 & 75 & 334 & 320 & 27 & 45 & 3832 & 3167 & 4678 & 3628 \\
\hline & média & 147,6 & 146,9 & 334,5 & 291,8 & 39,8 & 44,8 & 3183,5 & 2360,1 & 4092,5 & 3336,0 \\
\hline & Desvio & 41,4 & 39,7 & 51,0 & 40,5 & 18,5 & 21,0 & 488,0 & 347,3 & 511,6 & 458,6 \\
\hline
\end{tabular}


ANÁLISE DE SÓLIDOS - ETAPA TESTE - Cont.

\begin{tabular}{|c|c|c|c|c|c|c|c|c|c|c|}
\hline & \multicolumn{8}{|c|}{ SSF } & \multicolumn{2}{|c|}{ SF } \\
\hline Tempo & Entrada A & Entrada B & Ent. A (lise) & Ent. B (lise) & Saída A & Saída B & Tanque $\mathrm{A}$ & Tanque B & Tanque A & Tanque $\mathrm{B}$ \\
\hline 8 & 3 & 3 & 5 & 21 & 1 & 2 & 179 & 112 & 869 & 831 \\
\hline 14 & 2 & 2 & 4 & 12 & 0 & 3 & 303 & 154 & 876 & 842 \\
\hline 24 & 6 & 21 & 60 & 15 & 0 & 0 & 365 & 268 & 898 & 811 \\
\hline 30 & 2 & 5 & 26 & 17 & 5 & 2 & 357 & 250 & 866 & 801 \\
\hline 36 & 8 & 4 & 49 & 23 & 3 & 11 & 345 & 196 & 759 & 867 \\
\hline 40 & 0 & 3 & 0 & 0 & 0 & 0 & 379 & 158 & 883 & 813 \\
\hline 44 & 28 & 6 & 69 & 70 & 24 & 35 & 457 & 263 & 1075 & 961 \\
\hline 62 & 4 & 0 & 47 & 39 & 5 & 4 & 143 & 107 & 737 & 781 \\
\hline 66 & 2 & 8 & 18 & 16 & 8 & 8 & 245 & 235 & 887 & 937 \\
\hline 74 & 22 & 8 & 31 & 35 & 10 & 20 & 315 & 292 & 904 & 886 \\
\hline 82 & 2 & 9 & 3 & 7 & 16 & 13 & 233 & 233 & 806 & 823 \\
\hline 90 & 13 & 6 & 66 & 24 & 25 & 21 & 412 & 374 & 1192 & 1219 \\
\hline 96 & 20 & 8 & 43 & 48 & 20 & 9 & 299 & 293 & 859 & 753 \\
\hline 110 & 18 & 15 & 66 & 41 & 8 & 17 & 239 & 318 & 706 & 772 \\
\hline 116 & 8 & 2 & 22 & 33 & 6 & 12 & 381 & 292 & 970 & 937 \\
\hline 124 & 7 & 13 & 17 & 40 & 2 & 2 & 314 & 274 & 820 & 939 \\
\hline 138 & 14 & 36 & 53 & 35 & 14 & 5 & 287 & 383 & 810 & 838 \\
\hline 142 & 12 & 14 & 39 & 35 & 14 & 10 & 340 & 388 & 994 & 940 \\
\hline 160 & 6 & 2 & 22 & 20 & 4 & 8 & 542 & 494 & 1117 & 1109 \\
\hline 166 & 1 & 7 & 39 & 21 & 1 & 6 & 623 & 681 & 1205 & 1082 \\
\hline média & 8,8 & 8,6 & 33,9 & 27,6 & 8,2 & 9,4 & 337,9 & 288,2 & 911,7 & 897,1 \\
\hline Desvio & 7,9 & 8,3 & 22,5 & 16,1 & 8,0 & 8,8 & 113,8 & 133,7 & 141,4 & 122,4 \\
\hline
\end{tabular}


ANÁLISE DE SÓLIDOS - ETAPA TESTE - Cont.

\begin{tabular}{|c|c|c|c|c|c|c|c|c|c|c|}
\hline & \multicolumn{8}{|c|}{ SSV } & \multicolumn{2}{|c|}{ SV } \\
\hline Tempo & Entrada A & Entrada B & Ent. A (lise) & Ent. B (lise) & Saída A & Saída B & Tanque $\mathrm{A}$ & Tanque B & Tanque $\mathrm{A}$ & Tanque $\mathrm{B}$ \\
\hline 8 & 163 & 203 & 310 & 319 & 65 & 16 & 2347 & 2045 & 2241 & 1790 \\
\hline 14 & 181 & 165 & 289 & 236 & 73 & 22 & 2367 & 1965 & 2636 & 2054 \\
\hline 24 & 167 & 134 & 321 & 312 & 45 & 23 & 2321 & 1942 & 2601 & 1961 \\
\hline 30 & 190 & 160 & 454 & 335 & 37 & 23 & 2240 & 1638 & 2571 & 1842 \\
\hline 36 & 136 & 204 & 358 & 310 & 15 & 43 & 2613 & 1930 & 2896 & 2419 \\
\hline 40 & 172 & 184 & 267 & 311 & 41 & 62 & 2815 & 2256 & 3766 & 3680 \\
\hline 44 & 145 & 99 & 248 & 227 & 22 & 32 & 2637 & 1669 & 3210 & 2216 \\
\hline 62 & 151 & 170 & 234 & 227 & 31 & 12 & 2605 & 1972 & 3018 & 2199 \\
\hline 66 & 139 & 145 & 289 & 239 & 48 & 46 & 2410 & 1872 & 2766 & 2231 \\
\hline 74 & 203 & 137 & 331 & 261 & 60 & 46 & 2482 & 2119 & 2911 & 2380 \\
\hline 82 & 173 & 145 & 267 & 250 & 21 & 59 & 2683 & 1846 & 3011 & 2451 \\
\hline 90 & 128 & 163 & 263 & 259 & 37 & 30 & 2889 & 2070 & 2907 & 2207 \\
\hline 96 & 175 & 135 & 310 & 245 & 24 & 66 & 2964 & 1940 & 3697 & 2579 \\
\hline 110 & 68 & 110 & 290 & 198 & 24 & 39 & 3233 & 2120 & 3726 & 2461 \\
\hline 116 & 136 & 173 & 339 & 265 & 21 & 27 & 3268 & 2248 & 3563 & 2480 \\
\hline 124 & 104 & 152 & 286 & 299 & 5 & 67 & 3317 & 2238 & 3667 & 2949 \\
\hline 138 & 62 & 58 & 302 & 269 & 9 & 29 & 3489 & 2233 & 3714 & 3097 \\
\hline 142 & 114 & 97 & 294 & 253 & 24 & 8 & 3514 & 2187 & 3676 & 2728 \\
\hline 160 & 77 & 63 & 267 & 169 & 32 & 28 & 3507 & 2662 & 3568 & 2510 \\
\hline 166 & 92 & 69 & 295 & 299 & 26 & 40 & 3208 & 2486 & 3472 & 2546 \\
\hline média & 138,8 & 138,3 & 300,7 & 264,2 & 33,0 & 35,9 & 2845,6 & 2071,9 & 3180,8 & 2438,9 \\
\hline Desvio & 41,4 & 43,5 & 47,4 & 43,2 & 18,0 & 17,6 & 436,5 & 248,5 & 481,0 & 442,3 \\
\hline
\end{tabular}




\section{PERFIL NUTRIENTES - ETAPA CONTROLE}

\begin{tabular}{|c|c|c|c|c|c|c|}
\hline \multirow[b]{3}{*}{ Tempo } & \multirow[b]{3}{*}{ Amostra } & \multirow{2}{*}{\multicolumn{2}{|c|}{$\begin{array}{l}\text { PERFIL } \\
\text { ml ácido }\end{array}$}} & \multicolumn{2}{|c|}{ Tempo } & \multirow{3}{*}{$\begin{array}{c}70 \\
\text { ml ácido } \\
\text { NTK }\end{array}$} \\
\hline & & & & \multicolumn{2}{|c|}{ absorbância } & \\
\hline & & DQO & $\mathrm{NH} 4$ & $\mathrm{NO} 2$ & NO3 & \\
\hline $0: 00$ & Entrada A & 440 & 0,11 & 0,003 & 0,125 & 0,52 \\
\hline $0: 00$ & Entrada B & 450 & 0,1 & 0,002 & 0,112 & 0,45 \\
\hline $0: 15$ & $1 \mathrm{~A}$ & 180 & 0,16 & 0,005 & 0,089 & 0,46 \\
\hline $0: 15$ & $1 \mathrm{~B}$ & 240 & 0,1 & 0,005 & 0,115 & 0,38 \\
\hline $0: 45$ & $2 \mathrm{~A}$ & 55 & 0,59 & 0,007 & 0,046 & 0,38 \\
\hline $0: 45$ & $2 B$ & 105 & 0,2 & 0,003 & 0,057 & 0,36 \\
\hline $1: 30$ & $3 \mathrm{~A}$ & 38 & 0,7 & 0,013 & 0,028 & 0,33 \\
\hline $1: 30$ & $3 \mathrm{~B}$ & 75 & 0,38 & 0,003 & 0,034 & 0,27 \\
\hline $2: 30$ & $4 \mathrm{~A}$ & 22 & 0,7 & 0,006 & 0,025 & 0,28 \\
\hline $2: 30$ & $4 \mathrm{~B}$ & 59 & 0,45 & 0,048 & 0,025 & 0,24 \\
\hline $4: 30$ & $5 \mathrm{~A}$ & 20 & 0,74 & 0,004 & 0,025 & 0,26 \\
\hline 4:30 & $5 \mathrm{~B}$ & 55 & 0,44 & 0,184 & 0,063 & 0,24 \\
\hline $7: 30$ & $6 \mathrm{~A}$ & 20 & 0,75 & 0,003 & 0,024 & 0,21 \\
\hline 7:30 & $6 \mathrm{~B}$ & 44 & 0,31 & 0,381 & 0,088 & 0,24 \\
\hline $12: 00$ & Saída A & 20 & 0,69 & 0,003 & 0,024 & 0,2 \\
\hline $12: 00$ & Saída B & 36 & 0,3 & 0,523 & 0,115 & 0,21 \\
\hline Tempo & Amostra & DQO & $\mathrm{NH} 4$ & NO2 & NO3 & NTK \\
\hline $0: 00$ & Entrada A & 440 & 0,11 & 0,003 & 0,125 & 0,52 \\
\hline $0: 15$ & $1 \mathrm{~A}$ & 180 & 0,16 & 0,005 & 0,089 & 0,46 \\
\hline $0: 45$ & $2 A$ & 55 & 0,59 & 0,007 & 0,046 & 0,38 \\
\hline $1: 30$ & $3 \mathrm{~A}$ & 38 & 0,7 & 0,013 & 0,028 & 0,33 \\
\hline $2: 30$ & $4 \mathrm{~A}$ & 22 & 0,7 & 0,006 & 0,025 & 0,28 \\
\hline $4: 30$ & $5 \mathrm{~A}$ & 20 & 0,74 & 0,004 & 0,025 & 0,26 \\
\hline 7:30 & $6 \mathrm{~A}$ & 20 & 0,75 & 0,003 & 0,024 & 0,21 \\
\hline $12: 00$ & Saída A & 20 & 0,69 & 0,003 & 0,024 & 0,2 \\
\hline Tempo & Amostra & DQO & $\mathrm{NH} 4$ & $\mathrm{NO} 2$ & $\mathrm{NO} 3$ & NTK \\
\hline 0:00 & Entrada B & 450 & 0,1 & 0,002 & 0,112 & 0,45 \\
\hline $0: 15$ & $1 \mathrm{~B}$ & 240 & 0,1 & 0,005 & 0,115 & 0,38 \\
\hline $0: 45$ & $2 \mathrm{~B}$ & 105 & 0,2 & 0,003 & 0,057 & 0,36 \\
\hline $1: 30$ & $3 \mathrm{~B}$ & 75 & 0,38 & 0,003 & 0,034 & 0,27 \\
\hline $2: 30$ & $4 \mathrm{~B}$ & 59 & 0,45 & 0,048 & 0,025 & 0,24 \\
\hline $4: 30$ & $5 \mathrm{~B}$ & 55 & 0,44 & 0,184 & 0,063 & 0,24 \\
\hline $7: 30$ & $6 \mathrm{~B}$ & 44 & 0,31 & 0,381 & 0,088 & 0,24 \\
\hline $12: 00$ & Saída B & 36 & 0,3 & 0,523 & 0,115 & 0,21 \\
\hline
\end{tabular}


PERFIL NUTRIENTES - ETAPA CONTROLE - Cont.

Tempo

ml ácido

absorbância

ml ácido

Tempo

\begin{tabular}{|c|r|}
\multicolumn{1}{c}{ Amostra } & \multicolumn{1}{c}{ DQ } \\
\hline Entrada A & 53 \\
\hline Entrada B & 415 \\
\hline $1 \mathrm{~A}$ & 220 \\
\hline $1 \mathrm{~B}$ & 150 \\
\hline $2 \mathrm{~A}$ & 48 \\
\hline $2 \mathrm{~B}$ & 47 \\
\hline $3 \mathrm{~A}$ & 2 \\
\hline $3 \mathrm{~B}$ & 24 \\
\hline $4 \mathrm{~A}$ & 2 \\
\hline $4 \mathrm{~B}$ & 22 \\
\hline $5 \mathrm{~A}$ & 2 \\
\hline $5 \mathrm{~B}$ & 20 \\
\hline $6 \mathrm{~A}$ & 20 \\
\hline $6 \mathrm{~B}$ & 20 \\
\hline Saída A & 20 \\
\hline Saída B & 20 \\
\hline
\end{tabular}

$\mathrm{NH} 4$

$\mathrm{NO} 2$

$\mathrm{NO} 3$

NTK

$0: 00$

$0: 00$

$0: 15$

$0: 15$

$0: 45$

$0: 45$

$1: 30$

$1: 30$

2:30

2:30

4:30

4:30

$7: 30$

7:30

12:00

12:00

535

0,003

0,146

0,6

\begin{tabular}{l|l}
\hline 15 & 0,1 \\
\hline
\end{tabular}

0,003

0,114

0,45

220

0,56

0,006

0,068

0,118

0,17

48

\begin{tabular}{l|l}
47 & 0,32
\end{tabular}

0,023

0,08

\begin{tabular}{l|l}
0,32 & \\
\hline 0,99 & 0,006 \\
\hline
\end{tabular}

\begin{tabular}{c|r}
0,08 & 0,37 \\
\hline 0,058 & 0,46 \\
\hline 0,04 & 0,32
\end{tabular}

\begin{tabular}{l|l}
\hline 2 & 0,99 \\
\hline 24 & 0,42 \\
\hline
\end{tabular}

0,42

\begin{tabular}{|c|c|c}
\hline 25 & 1 & 0,006 \\
\hline
\end{tabular}

\begin{tabular}{l|l}
22 & 0,41 \\
\hline
\end{tabular}

\begin{tabular}{l|l}
20 & 0,99 \\
\hline
\end{tabular}

\begin{tabular}{l|l}
20 & 1,01 \\
\hline
\end{tabular}

\begin{tabular}{l|l}
0,41 & 0,056 \\
\hline, 99 & 0,09
\end{tabular}

\begin{tabular}{l|l}
20 & 0,97 \\
\hline 20 & 0,13 \\
\hline
\end{tabular}

0,01
0,13
0,03

0,268

\begin{tabular}{c|c}
0,04 & 0,32 \\
\hline 0,04 & 0,3 \\
\hline 0,04 & 0,23 \\
\hline
\end{tabular}

\begin{tabular}{l|l}
0,04 & 0,3 \\
\hline 0,04 & 0,23
\end{tabular}

\begin{tabular}{l|l}
20 & 1,03 \\
\hline
\end{tabular}

0,033

\begin{tabular}{l|l}
1,03 & 0,013 \\
\hline
\end{tabular}

0,013

\begin{tabular}{l|l}
0,04 & 0,23 \\
\hline 0,04 & 0,32 \\
\hline 0,04 & 0,22
\end{tabular}

$\begin{array}{ll}0,04 & 0,32 \\ 0,04 & 0,22\end{array}$

Tempo

Amostra DQ

$\mathrm{NH} 4$

$\mathrm{NO} 2$

0,04

0,36

0:00

$0: 15$

$0: 45$

$1: 30$

$2: 30$

4:30

7:30

12:00

\begin{tabular}{|c|r|}
\hline Entrada A & 5 \\
\hline $1 \mathrm{~A}$ & 2 \\
\hline $2 \mathrm{~A}$ & 48 \\
\hline $3 \mathrm{~A}$ & 22 \\
\hline $4 \mathrm{~A}$ & 25 \\
\hline $5 \mathrm{~A}$ & 20 \\
\hline $6 \mathrm{~A}$ & 20 \\
\hline Saída A & 20 \\
\hline
\end{tabular}

535

0,1

0,003

$\mathrm{NO} 3$

\begin{tabular}{l|l}
0,04 & 0,27
\end{tabular}

0,106

\begin{tabular}{c|c}
0,106 & 0,1 \\
\hline 0,04 & 0,3 \\
\hline 0,141 & 0,11
\end{tabular}

0,1

Tempo

Saída A

\begin{tabular}{l|l}
48 & 0,8 \\
\hline
\end{tabular}

0,56

0,006

0,146

NTK

\begin{tabular}{|c|c|c|c|c|c|c|}
\hline Tempo & Amostra & DQO & $\mathrm{NH} 4$ & NO2 & NO3 & NTK \\
\hline 0:00 & Entrada B & 415 & 0,1 & 0,003 & 0,114 & 0,45 \\
\hline $0: 15$ & $1 \mathrm{~B}$ & 150 & 0,17 & 0,118 & 0,08 & 0,37 \\
\hline $0: 45$ & $2 \mathrm{~B}$ & 47 & 0,32 & 0 & 0,04 & 0,32 \\
\hline $1: 30$ & $3 \mathrm{~B}$ & 24 & 0,42 & 0 & 0,04 & 0,23 \\
\hline $2: 30$ & $4 \mathrm{~B}$ & 22 & 0,41 & 0,056 & 0,04 & 0,22 \\
\hline $4: 30$ & $5 \mathrm{~B}$ & 20 & 1,01 & 0,268 & 0,111 & 0,12 \\
\hline $7: 30$ & $6 \mathrm{~B}$ & 20 & 0,13 & 0,033 & 0,106 & 0,1 \\
\hline $12: 00$ & Saída B & 20 & 0,1 & 0,003 & 0,141 & 0,11 \\
\hline
\end{tabular}

FÓSFORO TOTAL

\begin{tabular}{|c|c|c|c|c|c|c|}
\hline TEMPO & ENT A & ENT B & SAI A & SAI B & $\%$ Rem A & $\%$ Rem B \\
\hline 0 & 2,4 & 2,6 & 0,7 & 0,7 & 72,7 & 74,1 \\
\hline 18 & 4,4 & 3,1 & 1,6 & 1,8 & 63,4 & 41,0 \\
\hline 70 & 3,5 & 3,4 & 1,5 & 2,2 & 56,5 & 36,9 \\
\hline 112 & 3,9 & 3,1 & 1,7 & 1,4 & 57,3 & 56,4 \\
\hline 142 & 4,0 & 2,7 & 1,6 & 1,2 & 59,9 & 56,2 \\
\hline 166 & 3,1 & 3,6 & 1,4 & 0,8 & 53,6 & 78,0 \\
\hline & & & & média & 60,6 & 57,1 \\
\hline
\end{tabular}


PERFIL DE NUTRIENTES - ETAPA TESTE

Data:

05/12/01

$\mathrm{ml}$ ácido

absorbância

$\mathrm{ml}$ ácido

\begin{tabular}{|c|c|c|c|c|c|c|}
\hline Tempo & Amostra & DQO & NH4 & NO2 & NO3 & NTK \\
\hline $0: 00$ & Entrada A & 0,281 & 0,22 & 0,003 & 0,182 & 0,74 \\
\hline $0: 00$ & Entrada B & 0,243 & 0,18 & 0,003 & 0,148 & 0,64 \\
\hline $0: 15$ & 1 A & 0,078 & 0,8 & 0,05 & 0,096 & 0,46 \\
\hline $0: 15$ & 1 B & 0,065 & 0,31 & 0,072 & 0,134 & 0,34 \\
\hline $0: 45$ & 2 A & 0,043 & 1,05 & 0,012 & 0,04 & 0,44 \\
\hline $0: 45$ & 2 B & 0,028 & 0,47 & 0,109 & 0,103 & 0,23 \\
\hline $1: 30$ & 3 A & 0,025 & 1,16 & 0,019 & 0,024 & 0,36 \\
\hline $1: 30$ & 3 B & 0,014 & 0,5 & 0,138 & 0,115 & 0,2 \\
\hline $2: 30$ & 4 A & 0,018 & 1,19 & 0,028 & 0,029 & 0,35 \\
\hline $2: 30$ & 4 B & 0,016 & 0,31 & 0,206 & 0,16 & 0,14 \\
\hline $4: 30$ & 5 A & 0,015 & 1,09 & 0,023 & 0,029 & 0,37 \\
\hline $4: 30$ & 5 B & 0,011 & 0,1 & 0,265 & 0,218 & 0,1 \\
\hline $7: 30$ & 6 A & 0,008 & 1,13 & 0,012 & 0,025 & 0,36 \\
\hline $7: 30$ & 6 B & 0,008 & 0,12 & 0,076 & 0,16 & 0,09 \\
\hline $12: 00$ & Saída A & 0,008 & 1,02 & 0,035 & 0,036 & 0,38 \\
\hline $12: 00$ & Saída B & 0,008 & 0,1 & 0,014 & 0,193 & 0,09 \\
\hline
\end{tabular}

\begin{tabular}{|c|c|c|c|c|c|c|}
\hline Tempo & Amostra & DQO & $\mathrm{NH} 4$ & $\mathrm{NO} 2$ & NO3 & NTK \\
\hline $0: 00$ & Entrada $\mathrm{A}$ & 0,281 & 0,22 & 0,003 & 0,182 & 0,74 \\
\hline $0: 15$ & $1 \mathrm{~A}$ & 0,078 & 0,8 & 0,05 & 0,096 & 0,46 \\
\hline $0: 45$ & $2 \mathrm{~A}$ & 0,043 & 1,05 & 0,012 & 0,04 & 0,44 \\
\hline $1: 30$ & $3 \mathrm{~A}$ & 0,025 & 1,16 & 0,019 & 0,024 & 0,36 \\
\hline $2: 30$ & $4 \mathrm{~A}$ & 0,018 & 1,19 & 0,028 & 0,029 & 0,35 \\
\hline 4:30 & $5 \mathrm{~A}$ & 0,015 & 1,09 & 0,023 & 0,029 & 0,37 \\
\hline $7: 30$ & $6 \mathrm{~A}$ & 0,008 & 1,13 & 0,012 & 0,025 & 0,36 \\
\hline $12: 00$ & Saída A & 0,008 & 1,02 & 0,035 & 0,036 & 0,38 \\
\hline
\end{tabular}

\begin{tabular}{c|c|c|c|c|c|c|}
\multicolumn{1}{c}{ Tempo } & Amostra & \multicolumn{1}{c}{ DQO } & NH4 & NO2 & NO3 & NTK \\
\hline $0: 00$ & Entrada B & 0,243 & 0,18 & 0,003 & 0,148 & 0,64 \\
\hline $0: 15$ & 1 B & 0,065 & 0,31 & 0,072 & 0,134 & 0,34 \\
\hline $0: 45$ & 2 B & 0,028 & 0,47 & 0,109 & 0,103 & 0,23 \\
\hline $1: 30$ & 3 B & 0,014 & 0,5 & 0,138 & 0,115 & 0,2 \\
\hline $2: 30$ & 4 B & 0,016 & 0,31 & 0,206 & 0,16 & 0,14 \\
\hline $4: 30$ & 5 B & 0,011 & 0,1 & 0,265 & 0,218 & 0,1 \\
\hline $7: 30$ & 6 B & 0,008 & 0,12 & 0,076 & 0,16 & 0,09 \\
\hline $12: 00$ & Saída B & 0,008 & 0,1 & 0,014 & 0,193 & 0,09 \\
\hline
\end{tabular}


PERFIL DE NUTRIENTES - ETAPA TESTE - Cont.

Data: $\quad 12 / 12 / 01$

$\mathrm{ml}$ ácido absorbância $\mathrm{ml}$ ácido abs

\begin{tabular}{|c|c|c|c|c|c|c|}
\hline Tempo & Amostra & NH4 & NO2 & NO3 & NTK & Fósforo \\
\hline $0: 00$ & Entrada A & 0,74 & 0,01 & 0,126 & 0,31 & 1,0281 \\
\hline $0: 00$ & Entrada B & 0,65 & 0,01 & 0,126 & 0,25 & 0,9769 \\
\hline $0: 15$ & 1 A & 0,49 & 0,01 & 0,046 & 0,85 & 1,0381 \\
\hline $0: 15$ & 1 B & 0,38 & 0,078 & 0,025 & 0,29 & 1,0516 \\
\hline $0: 45$ & 2 A & 0,42 & 0,016 & 0,025 & 1,11 & 1,0328 \\
\hline $0: 45$ & 2 B & 0,27 & 0,065 & 0,104 & 0,48 & 0,7953 \\
\hline $1: 30$ & 3 A & 0,4 & 0,007 & 0,025 & 1,2 & 0,8923 \\
\hline $1: 30$ & 3 B & 0,38 & 0,057 & 0,088 & 0,48 & 0,8682 \\
\hline $2: 30$ & 4 A & 0,41 & 0,003 & 0,025 & 1,2 & 0,9028 \\
\hline $2: 30$ & 4 B & 0,24 & 0,078 & 0,145 & 0,4 & 0,8776 \\
\hline $4: 30$ & 5 A & 0,37 & 0,02 & 0,025 & 1,13 & 0,8741 \\
\hline $4: 30$ & 5 B & 0,18 & 0,116 & 0,257 & 0,2 & 0,8264 \\
\hline $7: 30$ & 6 A & 0,35 & 0,003 & 0,135 & 1,11 & 0,8211 \\
\hline $7: 30$ & 6 B & 0,16 & 0,018 & 0,231 & 0,1 & 0,8476 \\
\hline $12: 00$ & Saída A & 0,37 & 0,043 & 0,128 & 1,17 & 0,8164 \\
\hline $12: 00$ & Saída B & 0,17 & 0,014 & 0,319 & 0,11 & 0,9464 \\
\hline
\end{tabular}

\begin{tabular}{|c|c|c|c|c|c|c|}
\multicolumn{1}{c}{ Tempo } & Amostra & NH4 & NO2 & NO3 & NTK & Fósforo \\
\hline $0: 00$ & Entrada A & 0,74 & 0,01 & 0,126 & 0,31 & 1,0281 \\
\hline $0: 15$ & $1 \mathrm{~A}$ & 0,49 & 0,01 & 0,046 & 0,85 & 1,0381 \\
\hline $0: 45$ & $2 \mathrm{~A}$ & 0,42 & 0,016 & 0,025 & 1,11 & 1,0328 \\
\hline $1: 30$ & $3 \mathrm{~A}$ & 0,4 & 0,007 & 0,025 & 1,2 & 0,8923 \\
\hline $2: 30$ & $4 \mathrm{~A}$ & 0,41 & 0,003 & 0,025 & 1,2 & 0,9028 \\
\hline $4: 30$ & $5 \mathrm{~A}$ & 0,37 & 0,02 & 0,025 & 1,13 & 0,8741 \\
\hline $7: 30$ & $6 \mathrm{~A}$ & 0,35 & 0,003 & 0,135 & 1,11 & 0,8211 \\
\hline $12: 00$ & Saída A & 0,37 & 0,043 & 0,128 & 1,17 & 0,8164 \\
\hline
\end{tabular}

\begin{tabular}{|c|c|c|c|c|c|c|}
\multicolumn{1}{c}{ Tempo } & Amostra & NH4 & NO2 & NO3 & NTK & Fósforo \\
\hline $0: 00$ & Entrada B & 0,65 & 0,01 & 0,126 & 0,25 & 0,9769 \\
\hline $0: 15$ & 1 B & 0,38 & 0,078 & 0,025 & 0,29 & 1,0516 \\
\hline $0: 45$ & 2 B & 0,27 & 0,065 & 0,104 & 0,48 & 0,7953 \\
\hline $1: 30$ & 3 B & 0,38 & 0,057 & 0,088 & 0,48 & 0,8682 \\
\hline $2: 30$ & 4 B & 0,24 & 0,078 & 0,145 & 0,4 & 0,8776 \\
\hline $4: 30$ & 5 B & 0,18 & 0,116 & 0,257 & 0,2 & 0,8264 \\
\hline $7: 30$ & 6 B & 0,16 & 0,018 & 0,231 & 0,1 & 0,8476 \\
\hline $12: 00$ & Saída B & 0,17 & 0,014 & 0,319 & 0,11 & 0,9464 \\
\hline
\end{tabular}


PERFIL DE NUTRIENTES - ETAPA TESTE - Cont.

Data:

$19 / 12 / 01$

$\mathrm{ml}$ ácido absorbância $\mathrm{ml}$ ácido abs

$\begin{array}{lllllll}\text { Tempo } & \text { Amostra } & \mathrm{NH} 4 & \mathrm{NO} 2 & \mathrm{NO} 3 & \mathrm{NTK} & \text { Fósforo }\end{array}$

\begin{tabular}{|c|c|c|c|c|c|c|}
\hline $0: 00$ & Entrada A & 0,17 & 0,003 & 0,182 & 0,77 & 1,1245 \\
\hline $0: 00$ & Entrada B & 0,07 & 0,003 & 0,171 & 0,66 & 1,5578 \\
\hline $0: 15$ & 1 A & 0,9 & 0,031 & 0,103 & 0,55 & 1,2674 \\
\hline $0: 15$ & 1 B & 0,24 & 0,157 & 0,165 & 0,34 & 1,2309 \\
\hline $0: 45$ & 2 A & 1,19 & 0,034 & 0,043 & 0,45 & 1,2662 \\
\hline $0: 45$ & 2 B & 0,44 & 0,212 & 0,17 & 0,26 & 1,1915 \\
\hline $1: 30$ & 3 A & 1,27 & 0,049 & 0,036 & 0,5 & 1,0022 \\
\hline $1: 30$ & 3 B & 0,37 & 0,313 & 0,198 & 0,26 & 0,9205 \\
\hline $2: 30$ & 4 A & 1,27 & 0,053 & 0,029 & 0,46 & 0,9728 \\
\hline $2: 30$ & 4 B & 0,2 & 0,365 & 0,268 & 0,17 & 0,9669 \\
\hline $4: 30$ & 5 A & 1,24 & 0,034 & 0,076 & 0,42 & 0,9493 \\
\hline $4: 30$ & 5 B & 0,09 & 0,024 & 0,249 & 0,18 & 1,0199 \\
\hline $7: 30$ & 6 A & 1,25 & 0,029 & 0,08 & 0,41 & 1,121 \\
\hline $7: 30$ & 6 B & 0,09 & 0,016 & 0,311 & 0,15 & 1,1962 \\
\hline $12: 00$ & Saída A & 1,37 & 0,034 & 0,043 & 0,42 & 0,9922 \\
\hline $12: 00$ & Saída B & 0,09 & 0,026 & 0,373 & 0,12 & 0,9028 \\
\hline
\end{tabular}

\begin{tabular}{|c|c|c|c|c|c|c|}
\hline Tempo & Amostra & NH4 & NO2 & NO3 & NTK & Fósforo \\
\hline $0: 00$ & Entrada A & 0,17 & 0,003 & 0,182 & 0,77 & 1,1245 \\
\hline $0: 15$ & $1 \mathrm{~A}$ & 0,9 & 0,031 & 0,103 & 0,55 & 1,2674 \\
\hline $0: 45$ & $2 \mathrm{~A}$ & 1,19 & 0,034 & 0,043 & 0,45 & 1,2662 \\
\hline $1: 30$ & $3 \mathrm{~A}$ & 1,27 & 0,049 & 0,036 & 0,5 & 1,0022 \\
\hline $2: 30$ & $4 \mathrm{~A}$ & 1,27 & 0,053 & 0,029 & 0,46 & 0,9728 \\
\hline $4: 30$ & $5 \mathrm{~A}$ & 1,24 & 0,034 & 0,076 & 0,42 & 0,9493 \\
\hline $7: 30$ & $6 \mathrm{~A}$ & 1,25 & 0,029 & 0,08 & 0,41 & 1,121 \\
\hline $12: 00$ & Saída A & 1,37 & 0,034 & 0,043 & 0,42 & 0,9922 \\
\hline
\end{tabular}

\begin{tabular}{|c|c|c|c|c|c|c|}
\hline Tempo & Amostra & NH4 & NO2 & NO3 & NTK & Fósforo \\
\hline $0: 00$ & Entrada B & 0,07 & 0,003 & 0,171 & 0,66 & 1,5578 \\
\hline $0: 15$ & 1 B & 0,24 & 0,157 & 0,165 & 0,34 & 1,2309 \\
\hline $0: 45$ & 2 B & 0,44 & 0,212 & 0,17 & 0,26 & 1,1915 \\
\hline $1: 30$ & 3 B & 0,37 & 0,313 & 0,198 & 0,26 & 0,9205 \\
\hline $2: 30$ & 4 B & 0,2 & 0,365 & 0,268 & 0,17 & 0,9669 \\
\hline $4: 30$ & 5 B & 0,09 & 0,024 & 0,249 & 0,18 & 1,0199 \\
\hline $7: 30$ & 6 B & 0,09 & 0,016 & 0,311 & 0,15 & 1,1962 \\
\hline $12: 00$ & Saída B & 0,09 & 0,026 & 0,373 & 0,12 & 0,9028 \\
\hline
\end{tabular}


PERFIL DE NUTRIENTES - ETAPA TESTE - Cont.

Data: $\quad 03 / 01 / 02$

\begin{tabular}{c|c|c|c|c|c|c|}
\multicolumn{1}{c}{} & \multicolumn{2}{c}{ ml ácido } & \multicolumn{2}{c}{ absorbância } & \multicolumn{1}{c}{ ml ácido } & abs \\
\multicolumn{1}{c}{ Tempo } & Amostra & NH4 & NO2 & \multicolumn{1}{c}{ NO3 } & NTK & \multicolumn{1}{c|}{ Fósforo } \\
\hline $0: 00$ & Entrada A & 0,17 & 0,003 & 0,158 & 0,7 & 1,1245 \\
\hline $0: 00$ & Entrada B & 0,14 & 0,003 & 0,159 & 0,72 & 1,5578 \\
\hline $0: 15$ & 1 A & 1,03 & 0,012 & 0,096 & 0,68 & 1,2674 \\
\hline $0: 15$ & 1 B & 0,35 & 0,165 & 0,167 & 0,49 & 1,2309 \\
\hline $0: 45$ & 2 A & 1,27 & 0,031 & 0,055 & 0,51 & 1,2662 \\
\hline $0: 45$ & 2 B & 0,44 & 0,204 & 0,167 & 0,36 & 1,1915 \\
\hline $1: 30$ & 3 A & 1,43 & 0,037 & 0,044 & 0,52 & 1,0022 \\
\hline $1: 30$ & 3 B & 0,44 & 0,353 & 0,237 & 0,25 & 0,9205 \\
\hline $2: 30$ & 4 A & 1,45 & 0,031 & 0,038 & 0,48 & 0,9728 \\
\hline $2: 30$ & 4 B & 0,4 & 0,414 & 0,288 & 0,22 & 0,9669 \\
\hline $4: 30$ & 5 A & 1,4 & 0,024 & 0,023 & 0,51 & 0,9493 \\
\hline $4: 30$ & 5 B & 0,12 & 0,229 & 0,361 & 0,15 & 1,0199 \\
\hline $7: 30$ & 6 A & 1,47 & 0,072 & 0,068 & 0,54 & 1,121 \\
\hline $7: 30$ & 6 B & 0,12 & 0,043 & 0,412 & 0,15 & 1,1962 \\
\hline $12: 00$ & Saída A & 1,6 & 0,055 & 0,069 & 0,57 & 0,9922 \\
\hline $12: 00$ & Saída B & 0,12 & 0,03 & 0,45 & 0,15 & 0,9028 \\
\hline
\end{tabular}

\begin{tabular}{l}
\multicolumn{1}{c}{ Tempo } \\
\begin{tabular}{|c|c|c|c|c|c|c|}
\multicolumn{1}{c}{ Amostra } & NH4 & NO2 & NO3 & NTK & Fósforo \\
\hline $0: 00$ & Entrada A & 0,17 & 0,003 & 0,158 & 0,7 & 1,1245 \\
\hline $0: 15$ & $1 \mathrm{~A}$ & 1,03 & 0,012 & 0,096 & 0,68 & 1,2674 \\
\hline $0: 45$ & $2 \mathrm{~A}$ & 1,27 & 0,031 & 0,055 & 0,51 & 1,2662 \\
\hline $1: 30$ & $3 \mathrm{~A}$ & 1,43 & 0,037 & 0,044 & 0,52 & 1,0022 \\
\hline $2: 30$ & $4 \mathrm{~A}$ & 1,45 & 0,031 & 0,038 & 0,48 & 0,9728 \\
\hline $4: 30$ & $5 \mathrm{~A}$ & 1,4 & 0,024 & 0,023 & 0,51 & 0,9493 \\
\hline $7: 30$ & $6 \mathrm{~A}$ & 1,47 & 0,072 & 0,068 & 0,54 & 1,121 \\
\hline $12: 00$ & Saída A & 1,6 & 0,055 & 0,069 & 0,57 & 0,9922 \\
\hline
\end{tabular}
\end{tabular}

\begin{tabular}{|c|c|c|c|c|c|c|}
\hline Tempo & Amostra & $\mathrm{NH} 4$ & $\mathrm{NO} 2$ & NO3 & NTK & Fósforo \\
\hline 0:00 & Entrada B & 0,14 & 0,003 & 0,159 & 0,72 & 1,5578 \\
\hline $0: 15$ & $1 \mathrm{~B}$ & 0,35 & 0,165 & 0,167 & 0,49 & 1,2309 \\
\hline $0: 45$ & $2 \mathrm{~B}$ & $\overline{0,44}$ & 0,204 & 0,167 & 0,36 & 1,1915 \\
\hline $1: 30$ & $3 \mathrm{~B}$ & 0,44 & 0,353 & 0,237 & 0,25 & 0,9205 \\
\hline $2: 30$ & $4 \mathrm{~B}$ & 0,4 & 0,414 & 0,288 & 0,22 & 0,9669 \\
\hline $4: 30$ & $5 \mathrm{~B}$ & 0,12 & 0,229 & 0,361 & 0,15 & 1,0199 \\
\hline $7: 30$ & $6 \mathrm{~B}$ & 0,12 & 0,043 & 0,412 & 0,15 & 1,1962 \\
\hline $12: 00$ & Saída B & 0,12 & 0,03 & 0,45 & 0,15 & 0,9028 \\
\hline
\end{tabular}


PERFIL DE NUTRIENTES - ETAPA TESTE - Cont.

Data: $\quad 14 / 01 / 02$

$\mathrm{ml}$ ácido absorbância $\mathrm{ml}$ ácido abs

$\begin{array}{lllllll}\text { Tempo Amostra } & \mathrm{NH} 4 & \mathrm{NO} 2 & \mathrm{NO} 3 & \mathrm{NTK} & \text { Fósforo }\end{array}$

\begin{tabular}{|c|c|c|c|c|c|c|}
\hline $0: 00$ & Entrada A & 0,3 & 0,003 & 0,149 & 0,78 & 0,397 \\
\hline $0: 00$ & Entrada B & 0,23 & 0,003 & 0,144 & 0,71 & 0,373 \\
\hline $0: 15$ & $1 \mathrm{~A}$ & 0,94 & 0,013 & 0,101 & 0,51 & 0,434 \\
\hline $0: 15$ & $1 \mathrm{~B}$ & 0,34 & 0,098 & 0,131 & 0,43 & 0,41 \\
\hline $0: 45$ & $2 \mathrm{~A}$ & 1,28 & 0,032 & 0,065 & 0,46 & 0,395 \\
\hline $0: 45$ & $2 \mathrm{~B}$ & 0,44 & 0,196 & 0,161 & 0,3 & 0,363 \\
\hline $1: 30$ & 3 A & 1,23 & 0,055 & 0,049 & 0,43 & 0,373 \\
\hline $1: 30$ & 3 B & 0,38 & 0,194 & 0,196 & 0,22 & 0,332 \\
\hline $2: 30$ & 4 A & 1,17 & 0,076 & 0,038 & 0,43 & 0,351 \\
\hline $2: 30$ & 4 B & 0,2 & 0,394 & 0,163 & 0,17 & 0,315 \\
\hline $4: 30$ & 5 A & 1,12 & 0,045 & 0,023 & 0,4 & 0,322 \\
\hline $4: 30$ & 5 B & 0,18 & 0,084 & 0,277 & 0,14 & 0,304 \\
\hline $7: 30$ & 6 A & 1,13 & 0,072 & 0,055 & 0,44 & 0,326 \\
\hline $7: 30$ & 6 B & 0,17 & 0,026 & 0,316 & 0,14 & 0,301 \\
\hline $12: 00$ & Saída A & 1,19 & 0,074 & 0,058 & 0,44 & 0,308 \\
\hline $12: 00$ & Saída B & 0,15 & 0,024 & 0,293 & 0,14 & 0,322 \\
\hline
\end{tabular}

\begin{tabular}{|c|c|c|c|c|c|c|}
\hline Tempo & Amostra & \multicolumn{1}{c}{$\mathrm{NH} 4$} & $\mathrm{NO} 2$ & $\mathrm{NO} 3$ & $\mathrm{NTK}$ & Fósforo \\
\hline $0: 00$ & Entrada A & 0,3 & 0,003 & 0,149 & 0,78 & 0,397 \\
\hline $0: 15$ & $1 \mathrm{~A}$ & 0,94 & 0,013 & 0,101 & 0,51 & 0,434 \\
\hline $0: 45$ & $2 \mathrm{~A}$ & 1,28 & 0,032 & 0,065 & 0,46 & 0,395 \\
\hline $1: 30$ & $3 \mathrm{~A}$ & 1,23 & 0,055 & 0,049 & 0,43 & 0,373 \\
\hline $2: 30$ & $4 \mathrm{~A}$ & 1,17 & 0,076 & 0,038 & 0,43 & 0,351 \\
\hline $4: 30$ & $5 \mathrm{~A}$ & 1,12 & 0,045 & 0,023 & 0,4 & 0,322 \\
\hline $7: 30$ & $6 \mathrm{~A}$ & 1,13 & 0,072 & 0,055 & 0,44 & 0,326 \\
\hline $12: 00$ & Saída A & 1,19 & 0,074 & 0,058 & 0,44 & 0,308 \\
\hline
\end{tabular}

\begin{tabular}{|c|c|c|c|c|c|c|}
\hline \multicolumn{1}{c}{ Tempo } & \multicolumn{1}{c}{ Amostra } & \multicolumn{1}{c}{ NH4 } & NO2 & NO3 & NTK & Fósforo \\
\hline $0: 00$ & Entrada B & 0,23 & 0,003 & 0,144 & 0,71 & 0,373 \\
\hline $0: 15$ & 1 B & 0,34 & 0,098 & 0,131 & 0,43 & 0,41 \\
\hline $0: 45$ & 2 B & 0,44 & 0,196 & 0,161 & 0,3 & 0,363 \\
\hline $1: 30$ & 3 B & 0,38 & 0,194 & 0,196 & 0,22 & 0,332 \\
\hline $2: 30$ & 4 B & 0,2 & 0,394 & 0,163 & 0,17 & 0,315 \\
\hline $4: 30$ & 5 B & 0,18 & 0,084 & 0,277 & 0,14 & 0,304 \\
\hline $7: 30$ & 6 B & 0,17 & 0,026 & 0,316 & 0,14 & 0,301 \\
\hline $12: 00$ & Saída B & 0,15 & 0,024 & 0,293 & 0,14 & 0,322 \\
\hline
\end{tabular}


PERFIL DE NUTRIENTES - ETAPA TESTE - Cont.

Data: $\quad 21 / 01 / 02$

$\mathrm{ml}$ ácido absorbância ml ácido abs

\begin{tabular}{|c|c|c|c|c|c|c|}
\hline Tempo & Amostra & NH4 & NO2 & NO3 & NTK & Fósforo \\
\hline $0: 00$ & Entrada A & 0,18 & 0,004 & 0,118 & 0,76 & 0,318 \\
\hline $0: 00$ & Entrada B & 0,23 & 0,007 & 0,182 & 0,79 & 0,456 \\
\hline $0: 15$ & 1 A & 0,99 & 0,112 & 0,098 & 0,48 & 0,418 \\
\hline $0: 15$ & 1 B & 0,36 & 0,193 & 0,199 & 0,42 & 0,521 \\
\hline $0: 45$ & 2 A & 1,18 & 0,166 & 0,064 & 0,42 & 0,378 \\
\hline $0: 45$ & 2 B & 0,54 & 0,133 & 0,132 & 0,33 & 0,437 \\
\hline $1: 30$ & 3 A & 1,13 & 0,187 & 0,061 & 0,38 & 0,365 \\
\hline $1: 30$ & 3 B & 0,46 & 0,255 & 0,196 & 0,27 & 0,386 \\
\hline $2: 30$ & 4 A & 1,1 & 0,235 & 0,066 & 0,38 & 0,349 \\
\hline $2: 30$ & 4 B & 0,2 & 0,323 & 0,223 & 0,19 & 0,366 \\
\hline $4: 30$ & 5 A & 1,03 & 0,325 & 0,079 & 0,36 & 0,334 \\
\hline $4: 30$ & 5 B & 0,07 & 0,098 & 0,252 & 0,15 & 0,311 \\
\hline $7: 30$ & 6 A & 1,03 & 0,438 & 0,102 & 0,36 & 0,315 \\
\hline $7: 30$ & 6 B & 0,07 & 0,111 & 0,213 & 0,15 & 0,341 \\
\hline $12: 00$ & Saída A & 1,03 & 0,512 & 0,104 & 0,37 & 0,365 \\
\hline $12: 00$ & Saída B & 0,07 & 0,087 & 0,262 & 0,15 & 0,33 \\
\hline
\end{tabular}

\begin{tabular}{|c|c|c|c|c|c|c|}
\hline Tempo & Amostra & NH4 & NO2 & NO3 & NTK & Fósforo \\
\hline $0: 00$ & Entrada A & 0,18 & 0,004 & 0,118 & 0,76 & 0,318 \\
\hline $0: 15$ & $1 \mathrm{~A}$ & 0,99 & 0,112 & 0,098 & 0,48 & 0,418 \\
\hline $0: 45$ & $2 \mathrm{~A}$ & 1,18 & 0,166 & 0,064 & 0,42 & 0,378 \\
\hline $1: 30$ & $3 \mathrm{~A}$ & 1,13 & 0,187 & 0,061 & 0,38 & 0,365 \\
\hline $2: 30$ & $4 \mathrm{~A}$ & 1,1 & 0,235 & 0,066 & 0,38 & 0,349 \\
\hline $4: 30$ & $5 \mathrm{~A}$ & 1,03 & 0,325 & 0,079 & 0,36 & 0,334 \\
\hline $7: 30$ & $6 \mathrm{~A}$ & 1,03 & 0,438 & 0,102 & 0,36 & 0,315 \\
\hline $12: 00$ & Saída A & 1,03 & 0,512 & 0,104 & 0,37 & 0,365 \\
\hline
\end{tabular}

\begin{tabular}{|c|c|c|c|c|c|c|}
\hline Tempo & Amostra & $\mathrm{NH} 4$ & $\mathrm{NO} 2$ & NO3 & NTK & Fósforo \\
\hline 0:00 & Entrada B & 0,23 & 0,007 & 0,182 & 0,79 & 0,456 \\
\hline $0: 15$ & $1 \mathrm{~B}$ & 0,36 & 0,193 & 0,199 & 0,42 & 0,521 \\
\hline $0: 45$ & $2 \mathrm{~B}$ & 0,54 & 0,133 & 0,132 & 0,33 & 0,437 \\
\hline $1: 30$ & $3 \mathrm{~B}$ & 0,46 & 0,255 & 0,196 & 0,27 & 0,386 \\
\hline $2: 30$ & $4 \mathrm{~B}$ & 0,2 & 0,323 & 0,223 & 0,19 & 0,366 \\
\hline $4: 30$ & $5 \mathrm{~B}$ & 0,07 & 0,098 & 0,252 & 0,15 & 0,311 \\
\hline $7: 30$ & $6 \mathrm{~B}$ & 0,07 & 0,111 & 0,213 & 0,15 & 0,341 \\
\hline $12: 00$ & Saída B & 0,07 & 0,087 & 0,262 & 0,15 & 0,33 \\
\hline
\end{tabular}


PERFIL DE NUTRIENTES - ETAPA TESTE - Cont.

Data:

$28 / 01 / 02$

$\mathrm{ml}$ ácido

absorbância

$\mathrm{ml}$ ácido abs

\begin{tabular}{|c|c|c|c|c|c|c|}
\hline Tempo & Amostra & NH4 & NO2 & NO3 & NTK & Fósforo \\
\hline $0: 00$ & Entrada A & 0,16 & 0,0023 & 0,6655 & 0,44 & 0,318 \\
\hline $0: 00$ & Entrada B & 0,15 & 0,0016 & 0,8957 & 0,6 & 0,456 \\
\hline $0: 15$ & 1 A & 0,54 & 0,149 & 0,3264 & 0,25 & 0,418 \\
\hline $0: 15$ & 1 B & 0,38 & 0,0628 & 0,5695 & 0,36 & 0,521 \\
\hline $0: 45$ & 2 A & 0,62 & 0,1898 & 0,2999 & 0,22 & 0,378 \\
\hline $0: 45$ & 2 B & 0,55 & 0,0659 & 0,4359 & 0,27 & 0,437 \\
\hline $1: 30$ & 3 A & 0,54 & 0,244 & 0,3837 & 0,28 & 0,365 \\
\hline $1: 30$ & 3 B & 0,45 & 0,1216 & 0,6464 & 0,23 & 0,386 \\
\hline $2: 30$ & 4 A & 0,42 & 0,298 & 0,6026 & 0,21 & 0,349 \\
\hline $2: 30$ & 4 B & 0,22 & 0,1571 & 0,9003 & 0,16 & 0,366 \\
\hline $4: 30$ & 5 A & 0,28 & 0,454 & 0,7936 & 0,16 & 0,334 \\
\hline $4: 30$ & 5 B & 0,13 & 0,89 & 1,0516 & 0,12 & 0,311 \\
\hline $7: 30$ & 6 A & 0,2 & 0,59 & 1,1117 & 0,12 & 0,315 \\
\hline $7: 30$ & 6 B & 0,12 & 0,441 & 1,1135 & 0,13 & 0,341 \\
\hline $12: 00$ & Saída A & 0,14 & 0,784 & 1,5388 & 0,12 & 0,365 \\
\hline $12: 00$ & Saída B & 0,12 & 0,572 & 1,9 & 0,12 & 0,33 \\
\hline
\end{tabular}

$\begin{array}{lllllll}\text { Tempo } & \text { Amostra } & \mathrm{NH} 4 & \mathrm{NO} 2 & \mathrm{NO} 3 & \mathrm{NTK} & \text { Fósforo }\end{array}$

\begin{tabular}{|c|c|c|c|c|c|c|}
\hline $0: 00$ & Entrada A & 0,16 & 0,0023 & 0,6655 & 0,44 & 0,318 \\
\hline $0: 15$ & $1 \mathrm{~A}$ & 0,54 & 0,149 & 0,3264 & 0,25 & 0,418 \\
\hline $0: 45$ & $2 \mathrm{~A}$ & 0,62 & 0,1898 & 0,2999 & 0,22 & 0,378 \\
\hline $1: 30$ & $3 \mathrm{~A}$ & 0,54 & 0,244 & 0,3837 & 0,28 & 0,365 \\
\hline $2: 30$ & $4 \mathrm{~A}$ & 0,42 & 0,298 & 0,6026 & 0,21 & 0,349 \\
\hline $4: 30$ & $5 \mathrm{~A}$ & 0,28 & 0,454 & 0,7936 & 0,16 & 0,334 \\
\hline $7: 30$ & $6 \mathrm{~A}$ & 0,2 & 0,59 & 1,1117 & 0,12 & 0,315 \\
\hline $12: 00$ & Saída A & 0,14 & 0,784 & 1,5388 & 0,12 & 0,365 \\
\hline
\end{tabular}

$\begin{array}{llllll}\text { Tempo Amostra } & \mathrm{NH} 4 & \mathrm{NO} 2 & \mathrm{NO} 3 & \mathrm{NTK} & \text { Fósforo }\end{array}$

\begin{tabular}{|c|c|c|c|c|c|c|}
\hline $0: 00$ & Entrada B & 0,15 & 0,0016 & 0,8957 & 0,6 & 0,456 \\
\hline $0: 15$ & 1 B & 0,38 & 0,0628 & 0,5695 & 0,36 & 0,521 \\
\hline $0: 45$ & 2 B & 0,55 & 0,0659 & 0,4359 & 0,27 & 0,437 \\
\hline $1: 30$ & 3 B & 0,45 & 0,1216 & 0,6464 & 0,23 & 0,386 \\
\hline $2: 30$ & 4 B & 0,22 & 0,1571 & 0,9003 & 0,16 & 0,366 \\
\hline $4: 30$ & 5 B & 0,13 & 0,89 & 1,0516 & 0,12 & 0,311 \\
\hline $7: 30$ & 6 B & 0,12 & 0,441 & 1,1135 & 0,13 & 0,341 \\
\hline $12: 00$ & Saída B & 0,12 & 0,572 & 1,9 & 0,12 & 0,33 \\
\hline
\end{tabular}


PERFIL DE NUTRIENTES - ETAPA TESTE - Cont.

Data:

$18 / 02 / 02$

$\mathrm{ml}$ ácido

absorbância

$\mathrm{ml}$ ácido abs

\begin{tabular}{|c|c|c|c|c|c|c|}
\cline { 2 - 7 } \multicolumn{1}{c|}{ Tempo } & Amostra & NH4 & NO2 & NO3 & NTK & Fósforo \\
\hline $0: 00$ & Entrada A & 0,42 & 0,003 & 0,727 & 0,78 & 1,827 \\
\hline $0: 00$ & Entrada B & 0,43 & 0,003 & 0,7726 & 0,83 & 2,0097 \\
\hline $0: 15$ & $1 \mathrm{~A}$ & 0,41 & 0,121 & 0,3469 & 0,34 & 1,7753 \\
\hline $0: 15$ & $1 \mathrm{~B}$ & 0,38 & 0,1029 & 0,3534 & 0,37 & 1,7218 \\
\hline $0: 45$ & $2 \mathrm{~A}$ & 0,5 & 0,234 & 0,2868 & 0,18 & 0,8305 \\
\hline $0: 45$ & $2 \mathrm{~B}$ & 0,44 & 0,094 & 0,257 & 0,24 & 0,4878 \\
\hline $1: 30$ & 3 A & 0,4 & 0,354 & 0,4359 & 0,2 & 0,77 \\
\hline $1: 30$ & 3 B & 0,34 & 0,1118 & 0,3697 & 0,22 & 1,2113 \\
\hline $2: 30$ & 4 A & 0,32 & 0,503 & 0,5579 & 0,2 & 1,5201 \\
\hline $2: 30$ & 4 B & 0,24 & 0,1407 & 0,4731 & 0,15 & 1,409 \\
\hline $4: 30$ & 5 A & 0,13 & 0,648 & 0,7717 & 0,12 & 1,3708 \\
\hline $4: 30$ & 5 B & 0,11 & 0,844 & 0,5989 & 0,13 & 1,3111 \\
\hline $7: 30$ & 6 A & 0,11 & 0,616 & 0,822 & 0,12 & 1,4032 \\
\hline $7: 30$ & 6 B & 0,11 & 0,663 & 0,8583 & 0,1 & 1,3538 \\
\hline $12: 00$ & Saída A & 0,11 & 0,741 & 0,2384 & 0,1 & 2,5946 \\
\hline $12: 00$ & Saída B & 0,11 & 0,04 & 0,1994 & 0,1 & 2,382 \\
\hline
\end{tabular}

\begin{tabular}{|c|c|c|c|c|c|c|}
\hline Tempo & Amostra & \multicolumn{1}{c}{$\mathrm{NH} 4$} & $\mathrm{NO} 2$ & $\mathrm{NO} 3$ & $\mathrm{NTK}$ & Fósforo \\
\hline $0: 00$ & Entrada A & 0,42 & 0,003 & 0,727 & 0,78 & 1,827 \\
\hline $0: 15$ & $1 \mathrm{~A}$ & 0,41 & 0,121 & 0,3469 & 0,34 & 1,7753 \\
\hline $0: 45$ & $2 \mathrm{~A}$ & 0,5 & 0,234 & 0,2868 & 0,18 & 0,8305 \\
\hline $1: 30$ & $3 \mathrm{~A}$ & 0,4 & 0,354 & 0,4359 & 0,2 & 0,77 \\
\hline $2: 30$ & $4 \mathrm{~A}$ & 0,32 & 0,503 & 0,5579 & 0,2 & 1,5201 \\
\hline $4: 30$ & $5 \mathrm{~A}$ & 0,13 & 0,648 & 0,7717 & 0,12 & 1,3708 \\
\hline $7: 30$ & $6 \mathrm{~A}$ & 0,11 & 0,616 & 0,822 & 0,12 & 1,4032 \\
\hline $12: 00$ & Saída A & 0,11 & 0,741 & 0,2384 & 0,1 & 2,5946 \\
\hline
\end{tabular}

\begin{tabular}{|c|c|c|c|c|c|c|}
\multicolumn{1}{c}{ Tempo } & \multicolumn{1}{c}{ Amostra } & \multicolumn{1}{c}{ NH4 } & NO2 & NO3 & NTK & Fósforo \\
\hline $0: 00$ & Entrada B & 0,43 & 0,003 & 0,7726 & 0,83 & 2,0097 \\
\hline $0: 15$ & 1 B & 0,38 & 0,1029 & 0,3534 & 0,37 & 1,7218 \\
\hline $0: 45$ & 2 B & 0,44 & 0,094 & 0,257 & 0,24 & 0,4878 \\
\hline $1: 30$ & 3 B & 0,34 & 0,1118 & 0,3697 & 0,22 & 1,2113 \\
\hline $2: 30$ & 4 B & 0,24 & 0,1407 & 0,4731 & 0,15 & 1,409 \\
\hline $4: 30$ & 5 B & 0,11 & 0,844 & 0,5989 & 0,13 & 1,3111 \\
\hline $7: 30$ & 6 B & 0,11 & 0,663 & 0,8583 & 0,1 & 1,3538 \\
\hline $12: 00$ & Saída B & 0,11 & 0,04 & 0,1994 & 0,1 & 2,382 \\
\hline
\end{tabular}

